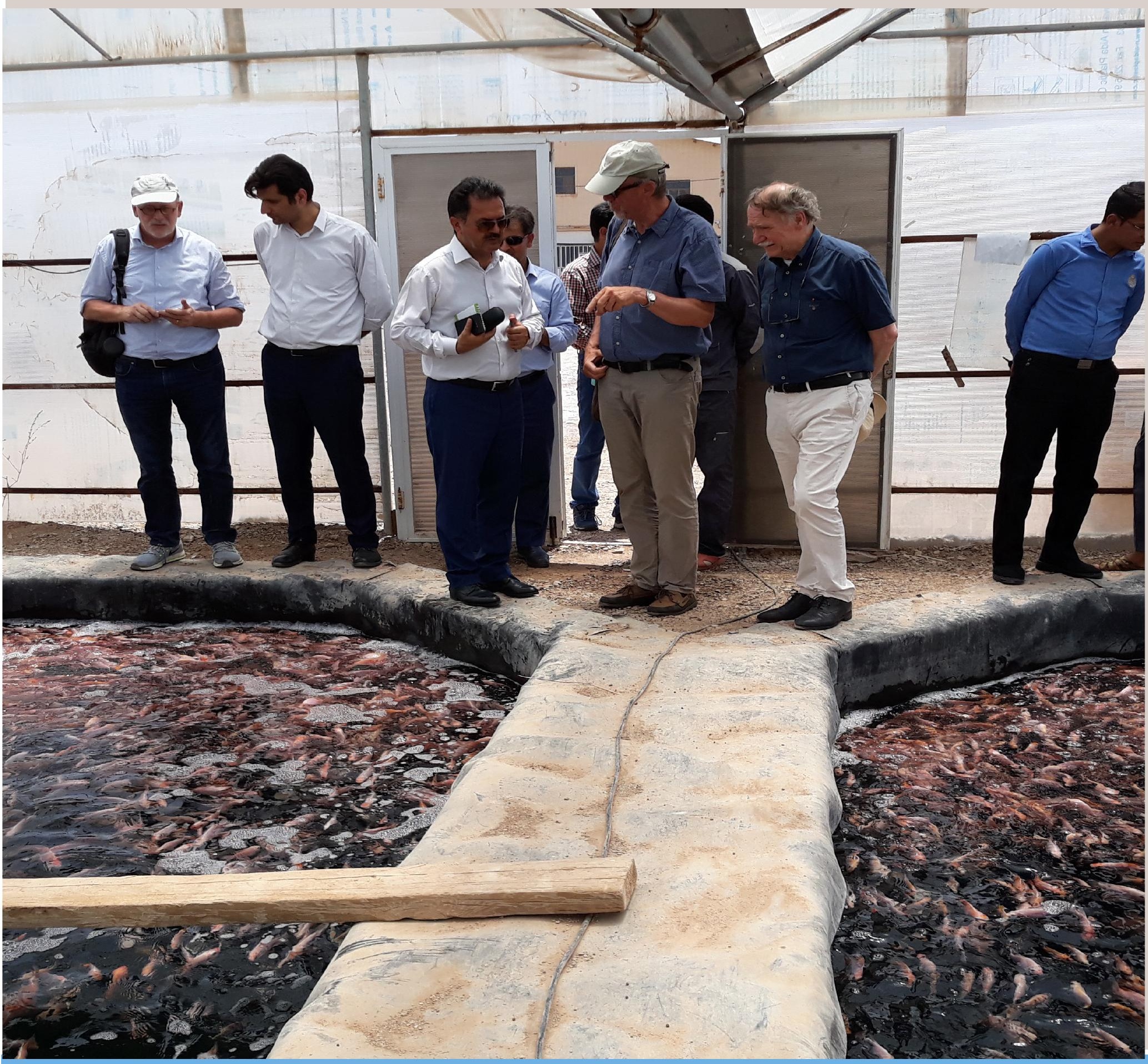

Improvement of the fish value chain in Iran: introduction of modern breeding technology, product innovation and value creation in fish and fish products 



\section{Improvement of the fish value chain in Iran: introduction of modern breeding technology, product innovation and value creation in fish and fish products.}

Results of the fact finding and goal establishing mission to the Islamic Republic of Iran (23-29 September 2017 and 8-13 June 2019).

Prof. Dr. Hans Komen ${ }^{1}$

Dr. ir. Jeroen Kals ${ }^{1}$

Ir. Leon Lomans ${ }^{2}$

Ir. Hans Smolders ${ }^{3}$

${ }^{1}$ Wageningen University \& Research, PO Box 338, 6700 AH Wageningen, the Netherlands

${ }^{2}$ The Dutch ministry of economic affairs

${ }^{3}$ The Netherlands embassy of Iran, Tehran.

Wageningen University \& Research

Wageningen, December 2019 
This report can be downloaded for free at http://dx.doi.org/10.18174/512378 or at www.wur.nl/livestock-research (under Wageningen Livestock Research publications).

\section{(C) 2020 Wageningen Livestock Research}

P.O. Box 338, 6700 AH Wageningen, The Netherlands, T +31 (0)317 483953 ,

E info.livestockresearch@wur.nl, www.wur.nl/livestock-research. Wageningen Livestock Research is part of Wageningen University \& Research.

All rights reserved. No part of this publication may be reproduced and/or made public, whether by print, photocopy, microfilm or any other means, without the prior permission of the publisher or author.

Wageningen Livestock Research is NEN-EN-ISO 9001:2015 certified.

All our research commissions are in line with the Terms and Conditions of the Animal Sciences Group. These are filed with the District Court of Zwolle. 


\section{Executive summary}

During a fact finding and goal establishing mission of $23^{\text {rd }}$ to the $29^{\text {th }}$ of September, 2017, prof Komen and dr Kals from Wageningen university, together with mr Smolders of the Dutch embassy in Teheran, and $\mathrm{mr}$ Lomans of the Ministry of Agriculture, Nature and Food quality in the Netherlands visited IFSRO research institutes in Anzali and Ahwaz, fish processing companies in the Persian gulf, and two institutes of the Iranian Fisheries Organisation or Shilat (IFO). Based on discussions with the Iranian deputy minister and colleagues from IFSRO, we identified several joint research and cooperation priorities:

For fish breeding, the single most important priority is the development of breeding programs for the existing and new species, to increase the productivity of the Iranian Aquaculture sector. This requires capacity building through training courses and joint research projects. Training courses can be offered online and on-site, with the purpose of delivering hands-on tools that can be used to develop and execute breeding programs capacity. Caspian brown trout is a high potential new species for the Caspian sea area. Broodstock has been imported which provides an excellent starting point for a dedicated breeding program. Tilapia is a species with high potential for development in the southern and desert areas of Iran. Environmental restrictions currently prohibit large scale culture. Dutch industry partners have expertise in recirculating aquaculture systems for tilapia and all-male production. A pilot should be identified which should involve IFSRO /IFO institutes and private partners to explore the development of tilapia culture under zero environmental impact conditions.

For fish processing four objectives are identified: 1. to increase the human consumption of the small pelagic species like anchovy, kilka and sardines currently used for fishmeal. 2 . To increase the resource use efficiency of tuna by products 3 . the increase of the use of lantern fish for both fishmeal and human consumption and 4 . The development of product using carp as a raw material. For each of the four goals a brief introduction, and suggested plan of action is described. Which of and how many of the four objectives can move into a pilot depends on the funding and priorities set by the private sector.

The persons involved in the mission are of the opinion that the Islamic Republic of Iran has great potential to increase aquaculture production/products in Iran through the introduction of new technologies (breeding and processing) and species. These will increase the added value and resource use efficiency of fish. The plans of action for joint research and cooperation are a good start to develop joint cooperation projects on these priority areas. Yet, the execution of the plans of action for joint research and cooperation has to be made concrete by the involvement of both IFSRO and the private sector. The involvement of IFSRO is instrumental for capacity building. The private sector is crucial for funding, production and commercialisation of the products developed.

In the second stage of this project, which took place from $8^{\text {th }}$ until the $13^{\text {th }}$ of June 2019 , a short mission, was organized. During the mission a pilot farm for brackish water farming of Nile tilapia was visited in Bafgh, followed by a meeting with the deputy governor of Yazd, and the director of AREEO in Yazd, to discuss the opportunities for a larger collaborative research project. The mission was followed by a one-day workshop on June 12 in Tehran where several experts of Dutch aquaculture production and trade gave presentations in a number of parallel sessions, jointly organized by IFSRI and the Netherlands Embassy. The workshop was highly successful and attracted more than 150 attendants, mostly Iranian representatives from the private sector, research institutes and others*.

*As a result of the Dutch Privacy Law (AVG), the names of the persons involved in the missions and the participants of the seminars, other than the authors or speakers of the seminars are not mentioned. 



\section{Table of contents}

$\begin{array}{lr}\text { Executive summary } & 3\end{array}$

$\begin{array}{llr}1 & \text { Background } & 9\end{array}$

$2 \quad$ Fish production in The Islamic Republic of Iran $\quad 10$

$\begin{array}{lll}2.1 & \text { Fisheries } & 10\end{array}$

2.2 Aquaculture 10

2.3 Market, economy and future development 11

$3 \quad$ The 2017 mission in brief $r$

$4 \quad$ To organize training in animal breeding for IFSRO scientists in Iran 15

$\begin{array}{llr}4.1 & \text { Introduction } & 15 \\ 4.2 & \text { Plan of action } & 15 \\ 4.3 & \text { Summary } & 15\end{array}$

5 To develop a pilot project on Nile tilapia, with a focus on zero environmental $\begin{array}{ll}\text { impact } & 16\end{array}$

$\begin{array}{lll}5.1 & \text { Introduction } & 16\end{array}$

5.2 Plan of action $\quad 16$

5.3 Summary 16

6 Development of a breeding program, focussing on one of the new target species $\begin{array}{ll}\text { for aquaculture in Iran. } & 17\end{array}$

$\begin{array}{lll}6.1 & \text { Introduction } & 17\end{array}$

$\begin{array}{ll}6.2 \text { Plan of action } & 17\end{array}$

$\begin{array}{lll}6.3 & \text { Summary } & 17\end{array}$

$7 \quad$ Increase the human consumption of the small pelagic species $\quad 18$

$\begin{array}{lll}7.1 & \text { Introduction } & 18\end{array}$

$\begin{array}{ll}7.2 & \text { Plan of action }\end{array}$

$\begin{array}{lll}7.3 & \text { Summary } & 19\end{array}$

8 Increase of the resource use efficiency (RUE) of tuna by products 20

$\begin{array}{lll}8.1 & \text { Introduction } & 20\end{array}$

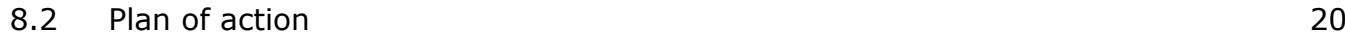

$\begin{array}{lll}8.3 \text { Summary } & 20\end{array}$

9 Increase of the use of lantern fish for both fishmeal and human consumption 22

$\begin{array}{lll}9.1 & \text { Introduction } & 22 \\ 9.2 & \text { Plan of action } & 22 \\ 9.3 & \text { Summary } & 22\end{array}$

$\begin{array}{llr}10 & \text { By products of carp } & 23\end{array}$

10.1 Introduction $\quad 23$

$\begin{array}{ll}10.2 \text { Plan of action } & 23\end{array}$

$\begin{array}{ll}10.3 \text { Summary } & 23\end{array}$ 
References

Appendix 3: Work plans (1 and 2) improvement of the fish value chain in Iran: value creation in fish and fish products

Appendix 6: Lantern fish project and the win-win supporting tilapia culture; ideas for a long term Lantern fish - Tilapia project. 


\section{$1 \quad$ Background}

In Vision 2025, the Iranian government indicates the wish to diversify the economy and become less dependent on the oil industry. Moreover, it is stated that food security is a top priority that needs to be improved by increasing the productivity of the agricultural, aquaculture and fisheries sector. This amongst others, can be achieved by a more efficient aquaculture industry with the processing of fish and by products of fish to high-quality products. With expertise, technology and products, Dutch institutions and industry can contribute to achieve this ambition.

Important questions related to this ambition are: How is the Iranian aquatic value chain organized? How can the value chain be optimized in the interaction between the species used, the current way of breeding, farming and harvesting, and the processing to minimise the losses and increase the added value of fish products. This project builds on a previously successful collaborative project focused on product innovation and the processing of by products from silver carp, which was conducted by Wageningen University \& Research (WUR) in cooperation with the Iranian Fish Research Institutes (IFRO) in Iran. Building on a recent visit of representatives of the Iranian Fisheries Science Research Institute (IFSRO) to Wageningen University, this new joint project focuses on the development of expertise, practical research, the implementation of expertise and production and commercialisation of products.

For this an integrated chain approach is required to answer the questions of fulfil the goals. In this project, it was decided to focus on the beginning and end of the value chain, because the Netherlands can provide high-quality, specific and unique expertise and technology related to selective breeding of fish, and the processing of fish and by-products of fish.

Wild fish is genetically optimally adapted to living in wild conditions, but not to the production conditions encountered in farms. This means that wild fish is less productive, less efficient and has higher mortalities, than fish that has been selected for growth in controlled aquaculture operations, such as tanks, raceways, ponds or cages. By selecting the best parents to produce offspring, the next generation will perform better in terms of growth. The process of doing this in a controlled manner is called selective breeding, and the planning, execution and evaluation of selective breeding is called a breeding program. Breeding programs can be used to improve growth, feed efficiency, fillet yield and product-quality. Currently the Iranian aquaculture industry is entirely dependent on species that were domesticated for many decades (carps), and import of fertilized eggs (rainbow trout). The Iranian government recognizes that this is an undesirable situation and that there is a urgent knowledge gap with respect to selective breeding.

The processing of fish involves fresh, frozen or otherwise conserved products with high added value. Often fish processing (e.g. filleting) is accompanied by huge losses of raw material. These so called by products can be processed into various products (e.g. meat analogues). Crucial when producing (novel) products is taking into account consumer preference and market potential of these products.

This project starts with an inventory of the current farming, (selective) breeding and processing methodologies of the main (farmed) fish species and their market potential in Iran. Based on the inventory and results of the fact and goal establishing mission, a seminar/workshop with all the relevant stakeholders was organized. One of the targets of the seminar is to define a larger public-private funded project with involvement of both Dutch and Iranian private sector. 


\section{Fish production in The Islamic Republic of Iran}

\section{$2.1 \quad$ Fisheries}

The total landings of the Iranian fishery sector in 2016 was 634000 tonnes of which approximately 600000 tonnes from the southern part and approximately 33000 tonnes of the northers part of The Islamic Republic of Iran. The landings in the southern region in 2016, which represents the Persian Gulf and the Oman Sea region, consisted out of the large pelagics or tuna species, the small pelagics or sardines and anchovy species, lantern fish, demersal species and shrimp with landings of 274533, 78507, 14809, 223533 and 9420 tonnes of each category respectively. From the large tuna species (yellow-fin, skipjack and long tail tuna) most, approximately 160000 tones, are used for the canning industry and the rest, approximately 115000 tonnes (e.g. King mackerel, Spanish mackerel), are going to the market fresh for direct human consumption. From the small pelagics $90 \%$ is used for the production of fishmeal and only a minor part $(10 \%)$ is used for human consumption. At the moment, a development plan is running to increase the landings of lantern fish from the current $20 \mathrm{kton} / \mathrm{y}$ to 100 $\mathrm{kton} / \mathrm{y}$ in the coming 5 years and, if successful, to $400 \mathrm{kton} / \mathrm{y}$ in the future. The maximum sustainable yield of lantern fish is estimated to be more than one million tons/y. The landings of $223 \mathrm{kton} / \mathrm{y}$ of demersal species, which consist of more than 60 different species, are going to the market fresh for direct human consumption. The landings in the northern region which represents the Caspian sea consisted of bony fish species (e.g. kutun, mullets, carps and bream) and Kilka with landings of 10926 and 22429 tonnes, respectively. The total landings of the fishery sector are more or less stable the last few years.

\subsection{Aquaculture}

The first attempts to culture fish in Iran started with the culture of rainbow trout near Tehran in 1959, followed by the culture of carp species in the Gilan Province in 1971 and shrimp in the early 90's in the Gulf region. The aquaculture industry developed strongly and the production increased from 3219 tonnes in 1978 to 371.840 tonnes in 2014. The main contributors to this total production are the carp species (common carp, silver carp, grass carp and bighead carp), with 170.341 tonnes ( 45 percent). Second comes rainbow trout with a production of 126.515 tonnes or approximately 34 percent, and third the aquaculture-based fisheries with 51.666 tonnes or approximately 14 percent of the total production. Shrimp production (mainly white leg shrimp) reached 22.475 tons in 2014 and almost doubled compared to 2013. Other species being promoted to diversify production and increase flexibility are the caspian trout, giant river prawn, beluga sturgeon, freshwater bream, Binni, pike perch, Sobaity bream, barramundi and orange-spotted grouper. A development plan is running in the Caspian Sea, the Persian Gulf and the Oman sea for the development of marine cage culture. The candidate species for the Caspian Sea include, among others, caspian trout and beluga sturgeon. The candidate species for The Gulf and the Oman sea include groupers, Sobaity bream, barramundi, cobia, silver pomfret and four finger threadfin. In order to support the requirements of juveniles for the growing fish farming industry, several government-run fish hatcheries were established for rainbow trout as well as a marine fish hatchery. However, more than 95 percent of the juveniles are currently produced by the private sector. The Iranian Fisheries Organization allocated the state owned hatcheries for the production of juvenile sturgeon and other bony fishes for use in the re-stocking programs of the Caspian Sea under its stock enhancement programme. 


\subsection{Market, economy and future development}

Fish consumption in Iran was low in the 1980's with a per capita consumption of $1 \mathrm{~kg} / \mathrm{year}$, yet increased substantially to $11 \mathrm{~kg} /$ year in 2017. The role of fish production (aquaculture and fisheries) as a contributor to the Iranian economy is small. The value of fish commodities exported in 2014 was USD 300 million. However, with the good potential for increase in production, especially for the aquaculture sector, it seems likely that its contribution to the country's economy will increase.

The aquaculture and fisheries production is important to the government for food security and the job opportunity aspect. The number of people employed in the sector has risen from 93.000 in 1993 to 208.000 by 2014 of which the number directly employed in the aquaculture sector is around 68.000 . Therefore, the fisheries industry is in a favourable position and the governmental support through investments in this sector is substantial. The government supports the private sector by providing low rate interest loans and suitable land at competitive prices. Moreover, to improve the link between research and the industry, the Minister for Science, Research and Technology will grant 60 percent of the funding required for research projects if $40 \%$ of the funding is paid directly by the industry. The sixth Iranian Fisheries Development Programme focussing on the further development of sustainable aquaculture started in April 2017. When successful, aquaculture production will increase from 371.840 tonnes in 2014 to 811.000 tonnes in 2021. During the sixth development plan, the amount of infrastructure funding for the Fisheries sector, will increase from USD 300 million (year 2014) to USD 530 million (year 2021) of which 60 percent will be allocated to the aquaculture sector. 


\section{The 2017 mission in brief}

The fact finding and goal establishing mission took place from the $23^{\text {rd }}$ to the $29^{\text {th }}$ of September, 2017 in the Islamic Republic of Iran. On Sunday the $24^{\text {th }}$, the first day of the mission, the delegation visited the Iranian Fisheries Science Research Organisation (IFSRO) and the Food and Agriculture Organization (FAO) in Teheran (figure 1). After lunch, on the request of IFSRO, the delegation was split in two groups. The first group, composed of prof Hans Komen of WUR and the assistant of mr Hans Smolders of the Netherlands embassy, went on a fact finding mission to assess the status of selective breeding research in two IFSRO institutes in Iran. The second group, composed of dr Jeroen Kals of WUR, mr Hans Smolders of the Netherlands embassy and mr Leon Lomans of the Dutch ministry of economic affairs, went to assess the state of art in fish processing in Iran. Their itineraries are given below:

Group1: on Monday $25^{\text {th }}$, the IFSRO National Inland Water Aquaculture Institute Domestic Aquaculture Research Centre in Anzali (Caspian sea region) was visited in the morning, followed by a visit to the Centre for the Reproduction of Warm Water Fish (IFO) in the afternoon, and a visit to a private carp fingerling producer. On return to Tehran, the delegation took an early morning flight on Tuesday $26^{\text {th }}$, to visit the Domestic Aquaculture Research Centre \& Warm Water Fish Research Centre in Ahwaz (Persian gulf region) and a cooperative carp farm complex near Ahwaz. Return to Teheran in the evening.

Group 2: On Monday the $25^{\text {th }}$, landing sites for anchovy, sardines and lantern fish and the Qeshm Fish Process Company, a fish meal processing plant processing anchovies, sardines and lantern fish at Qeshm Island were visited (figure 1). In the evening of the second day the delegation visited the Bandar Abbas Fish Processing Company, a tuna canning factor, followed by a visit to the Persian Gulf \& Aman Sea Ecological Research Institute in Bandar Abbas where they attended a seminar and met colleagues from the Hormozgan Fisheries Organisation (figure 2). After flying back to Teheran the delegation travelled to Bandar Anzali on Tuesday the $26^{\text {th }}$ to visit the Domestic Aquaculture Research Centre \& Processing institute (UNIDO) and the Bandarabas F.P.Co., also a tuna canning factory (figure 3). Return to Teheran in the evening

On Wednesday the $27^{\text {th }}$ a meeting was arranged with the Deputy Minister and Head of Iranian Fisheries Organisation, to discuss the challenges and priorities of the aquaculture and fish processing industry (figure 4) of Iran followed by a genetics workshop and a fish processing workshop (parallel sessions) at the Iranian Fisheries Science Research Organisation (figure 5). Following valuable concluding discussions with our Iranian colleagues on Thursday morning the $28^{\text {th }}$ (figure 5 ), the following priority areas were identified for further development.

\section{Breeding:}

1. To organize training in animal breeding for IFSRO scientists in Iran

2. To develop a pilot project, possibly on Nile tilapia, with a focus on zero environmental impact

3. To have a joint PHD project on fish breeding, focussing on one of the new target species for aquaculture in Iran, such as Caspian trout.

Processing of fish and/or by products of fish:

1. Increase of the human consumption of the small pelagic species currently used for fishmeal

2. Increase of the resource use efficiency of tuna by products

3. Increase of the use of Lantern fish for both fishmeal and human consumption

4. The development of products using carp as a raw material

Each of these goals are treated separately with a brief introduction and suggested plan of action as part of the report describing the results of the fact finding and goal establishing mission. As mentioned earlier, shrimp production in Iran is a minor aquaculture activity compared to fish. During the mission, it was decided to focus on finfish and shrimp was omitted due to time constraints. 

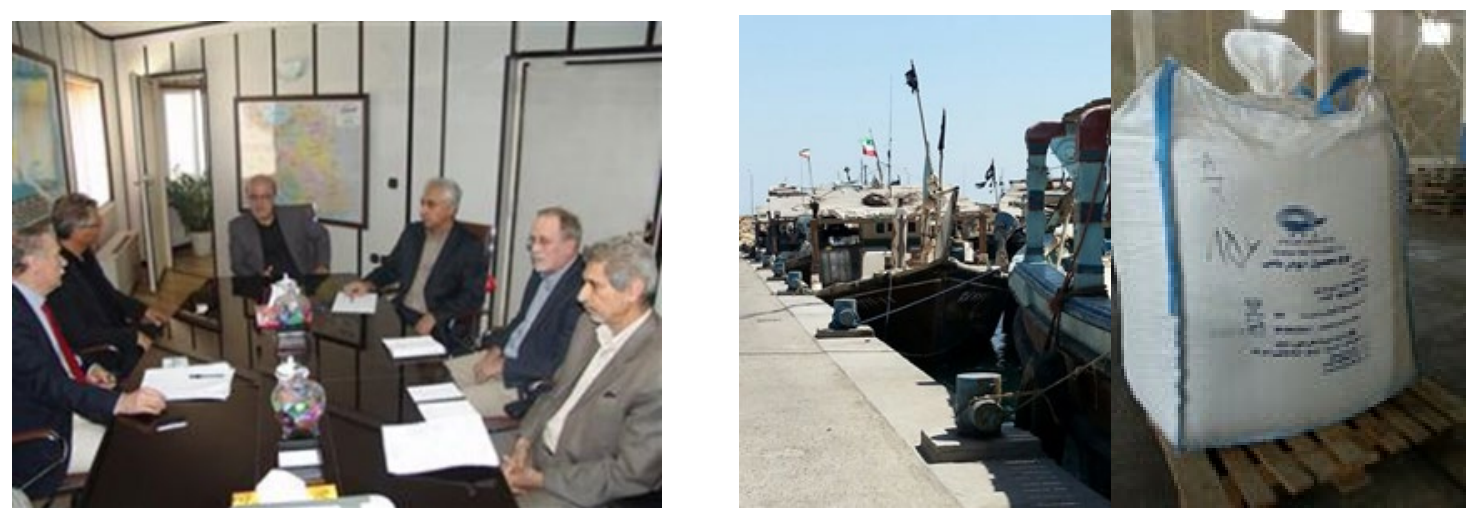

Figure 1 Visiting our colleagues at the Iranian Fisheries Science Research Organization (IFSRO) (left), the landing sites and the Qeshm Fish Process Company (right).
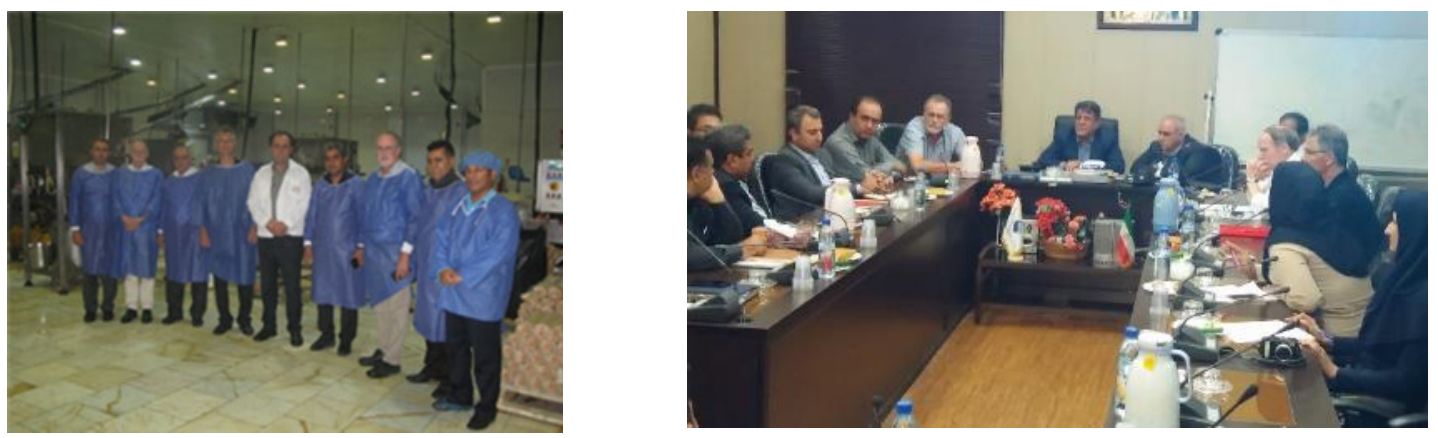

Figure 2 Visiting the Bandar Abbas Fish Processing Company (left) and our colleagues Persian Gulf \& Aman Sea Ecological Research Institute in Bandar Abbas (right).
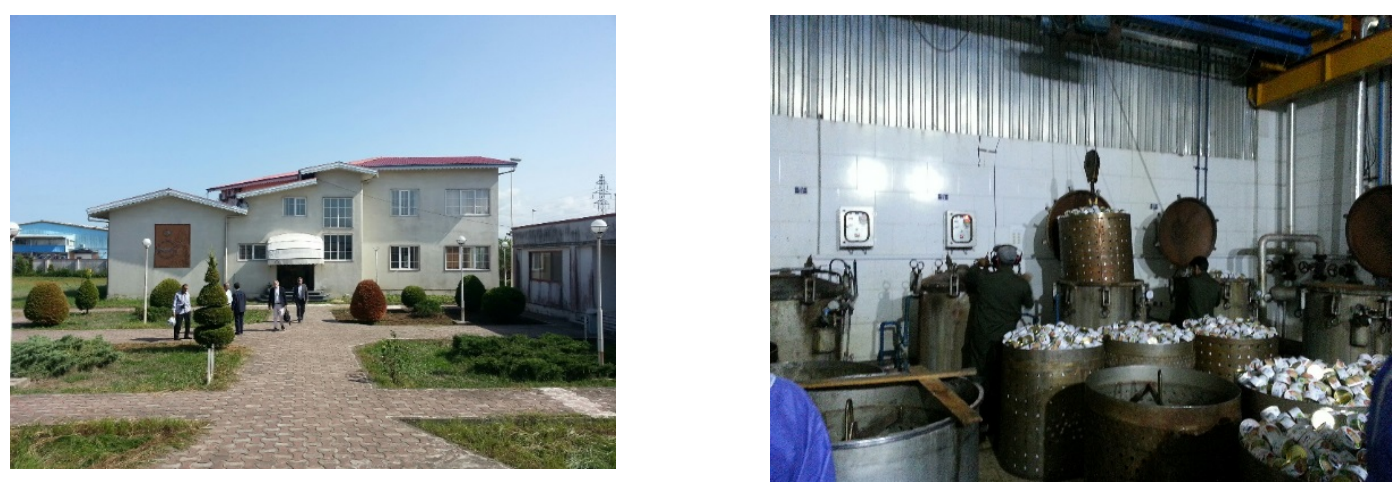

Figure 3 Visiting the Domestic Aquaculture Research Centre \& Processing institute (left) and the tuna canning factory.
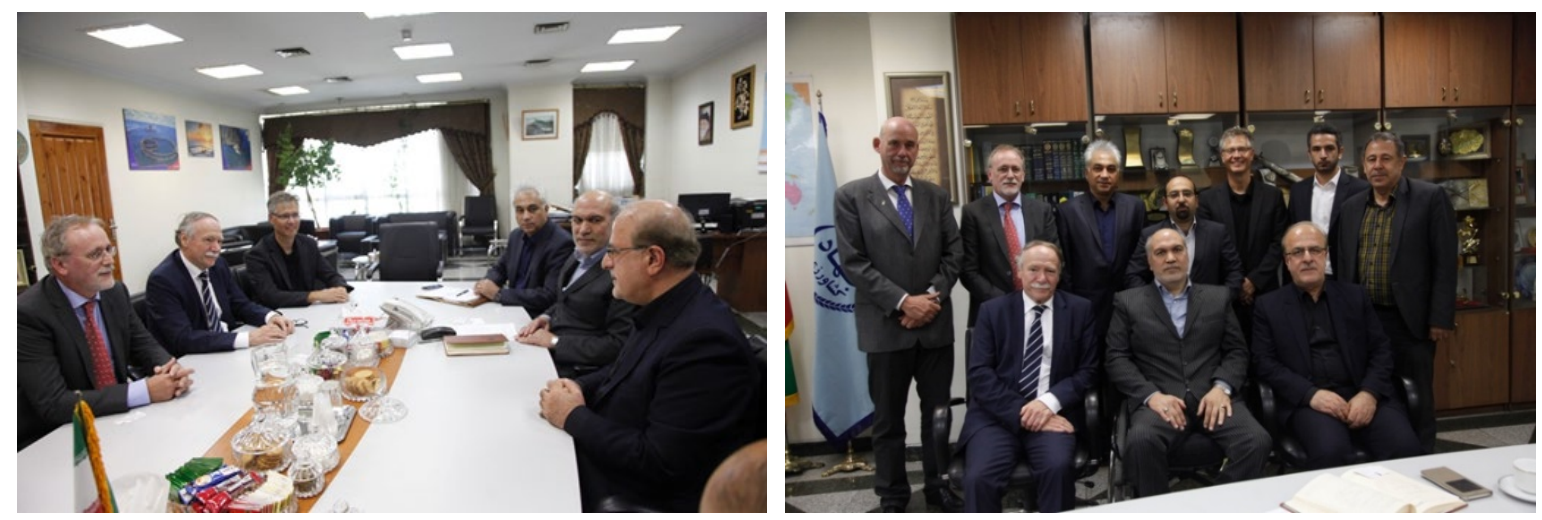

Figure 4 The meeting with the Deputy Minister and Head of Iranian Fisheries Organization, were the challenges and priorities of the aquaculture and fish processing industry of Iran were discussed 

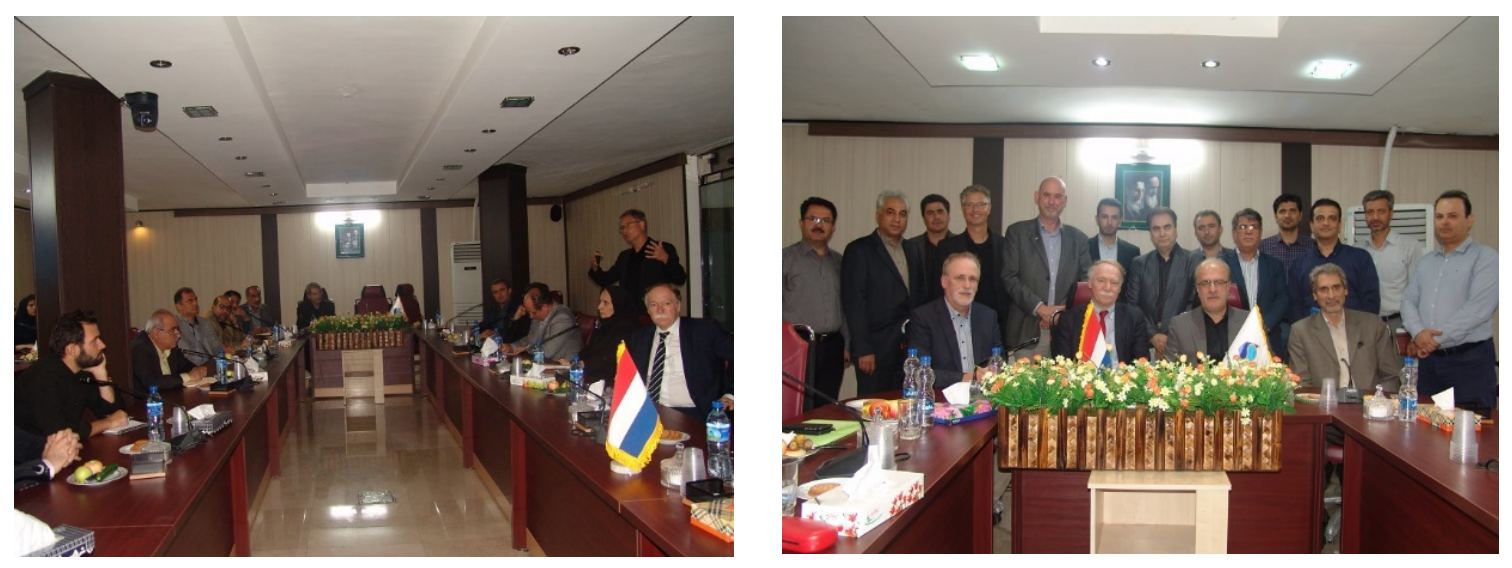

Figure 5 The fish processing workshop (left) and a final picture during the closing of the meeting for writing the draft proposal for the joint research program (right) both at the Iranian Fisheries Science Research Organization 


\section{4 \\ To organize training in animal breeding for IFSRO scientists in Iran}

\subsection{Introduction}

Currently the aquaculture industry in Iran relies on a limited number of species, most notably Rainbow trout, European carp and Chinese carps. While culture of these species is well established, several problems in the production exist. More importantly the markets for carp species are saturated due to overproduction and declining demands and export opportunities. For rainbow trout, the largest species (in USD value) produced in Iran, there is a need for locally executed breeding programs as import of eyed eggs from foreign breeding companies is no longer allowed. There are several native and exotic medium to high value species that could be introduced to Iranian aquaculture. These are Caspian brown trout (in cages in the Caspian sea), Kutum (in ponds and cages), Nile tilapia (in desert areas and provided they are completely sterile to prevent uncontrolled breeding of escapees), and marine species such as (Asian) seabass, bream and yellowtail kingfish. The successful introduction of new species and the upgrading of currently produced trout and carp species by means of selective breeding requires the input of trained staff from IFSRO institutes.

During the mission, it was established that there is an urgent need for high quality juveniles from dedicated breeding programs to bring the Iranian aquaculture sector to the next level. However, there are no breeding programs for any of the species mentioned, which is mainly due to lack of expertise and knowledge. Training and capacity building in the area of animal breeding and genetics is therefore urgently needed. Staff of IFSRO is well equipped to provide research and support in aquatic health and feed issues. However, knowledge and expertise in selective breeding is lacking.

\subsection{Plan of action}

Wageningen university is a world leader in research and education in animal breeding and genetics (ABG). The animal breeding and genetics group consists of $\sim 90$ tenured staff, post-docs and PhD students. Annually, some 30-40 MSc students take courses and do thesis research in various fields within the domain of $A B G$. ABG organizes and regularly give training courses in design and execution of breeding programs for professionals working in research organizations and industry. In recent years, the ABG group has also been developing an open online training course ("MOOC") on the design of animal breeding programs. This course is hosted on the freely accessible website EdX.org. In 2018, a second course will be developed that complements the first, and provides a solid first introduction to animal breeding and genetics for prospective MSc and PhD students, and professionals working in industry and research. We propose to organize a training programme that consists of the online courses and two on-site training courses on breeding program design. Prospective candidates for these courses should have a plan for, or be involved in, a breeding program. The first course focusses on design of breeding programs, the second on estimating breeding values.

\subsection{Summary}

Training of staff in animal breeding is the first step towards a successful upgrading of the Iranian fingerling production and diversification of aquaculture. Online courses provide an easy to implement first step towards training in ABG. The two dedicated on-site training courses will provide staff with the sufficient background to start and implement breeding programs for existing and new species in Iran. 


\section{To develop a pilot project on Nile tilapia, with a focus on zero environmental impact}

\subsection{Introduction}

Nile tilapia is currently in value the most important freshwater fish cultured worldwide. Annual production was 3.6 million tonnes in 2015 and is expected to double by 2030 (Worldbank report: "FISH TO 2030: Prospects for Fisheries and Aquaculture). Culture of tilapia is feasible in different areas in Iran, but is currently not allowed due to environmental restrictions. However, carp farmers in Ahwaz expressed a clear desire to change production to Nile tilapia if it would be allowed. Feral redbelly tilapia (Tilapia zillii, now classified as Coptodon zillii) is regarded as an invasive pest species. However, tilapia from the genus Oreochromis (O. aureus) are considered native to the middle east region.

The concern is that Nile tilapia, if introduced, will also become a pest, replacing native, endemic cyprinid species from their natural habitat (as is happening in China). Currently there is only one operation in Iran that is allowed to culture tilapia for experimental reasons which is the National Research Centre for Saline Aquatics, at Bafgh, Yazd Province.

\subsection{Plan of action}

Dutch aquaculture industry is well known for their expertise in design and building fresh water recirculating aquaculture systems (RAS). Several companies offer these services to clients worldwide. Next to this, one company (TilAqua) specializes in breeding all male tilapia fry for export to countries and companies where restrictions on hormone use (to produce monosex fry) are enforced. We propose that an industry mission will be organized in 2018 to: 1) assess grow out conditions and strain suitability in Ahwaz (or another region, to be discussed with IFSRO); 2); explore development of a $100 \%$ guaranteed technology to produce all-male tilapia in a joint venture setting, and 3) explore possibilities for an integrated pond-RAS system with zero effluent. The second step is the development of a pilot project to design a simple robust breeding program for all-male fry production. Based on outcomes of industry mission and the pilot, a public-private partnership can be developed where Dutch companies that offer RAS technology, are invited to participate.

\subsection{Summary}

Tilapia is a high potential species for the further development of aquaculture in Iran. However, culture can only be initiated if tilapia can be prevented from escaping and are $100 \%$ guaranteed male. The proposed industry mission will explore the potential for tilapia culture in combination with RAS and all male technology. The pilot will focus on the development of technology that guarantees $100 \%$ male production of fry. 


\section{6 Development of a breeding program, focussing on one of the new target species for aquaculture in Iran.}

\subsection{Introduction}

The Islamic republic of Iran is investigating the expansion of Aquaculture through the adoption of new species and new culture systems. One area of particular interest is the Caspian sea, with possibilities for cage culture. During the visit of the breeding delegation in Anzali, discussions were held around the suitability of two new species for cage culture in the Caspian sea: Caspian brown trout, and Kutum (an endemic cyprinid). Both species are endemic to the Caspian sea region and highly valued. However, culture technology for Kutum is not yet fully developed while for Caspian brown trout it is. Recently IFSRI imported brood stock of brown trout from Azerbaijan to start experiments with brown trout cage culture. The institute has some facilities for genetic analysis to assess e.g. genetic diversity. However, there are no plans for a breeding program as no expertise is available.

\subsection{Plan of action}

Capacity building is an important priority area for IFSRO institutes (pers. Comm., director of IFSRO). As part of a joint program between Wageningen university and IFSRO, we propose to develop a Caspian brown trout breeding program. This project will have two objectives - 1) capacity building by training high potential staff member(s) in animal breeding, and 2) design and implementation of a breeding program for Caspian brown trout. The design of a breeding program requires estimation of genetic parameters for traits of interest, e.g. growth rate and fillet quality through an experiment, and DNA analysis to develop markers that can be used to assess genetic diversity and in genomic selection approaches. Staff members will receive training in these expertise area's and execute the breeding program in Iran, under joint supervision. Results will be published in internationally renowned journals as well as Iranian scientific publications and outreach documents.

\subsection{Summary}

Caspian trout is a very important and high potential species for Iranian aquaculture in the Caspian sea region. Development of joint $\mathrm{PhD}$ project is proposed as a way to kick start a unique breeding program for this species. The project will not only train staff in animal breeding but also serve as anchor point for further initiatives on conservation of biodiversity in this rare and endangered species, and the development of a long-term viable cage culture industry for this species. 


\section{Increase the human consumption of the small pelagic species}

\subsection{Introduction}

In Iran currently most of the 100.000 ton of the small pelagic species caught (e.g. anchovy, sardine, kilka, figure 6) are used for the production of fishmeal. For example from kilka only $10 \%$ of the catch is used for human consumption, the rest is processed into fish meal. However, as the small pelagic species have a high nutritional value, also for humans (e.g. proteins and essential fatty acids), it is more efficient to use them for direct human consumption as you gain approximately a factor four by going down in trophic level. In addition, the Iranian government wants to stimulate the fish consumption in Iran as the average yearly consumption per capita is $11 \mathrm{~kg}$, which is almost half the global average.

During the fact finding and goal establishing mission a plan was made in consultation with our Iranian colleagues to increase the human consumption of the small pelagic species from the Gulf of Oman in the south (anchovy and sardines) and the Caspian Sea in the north (kilka).
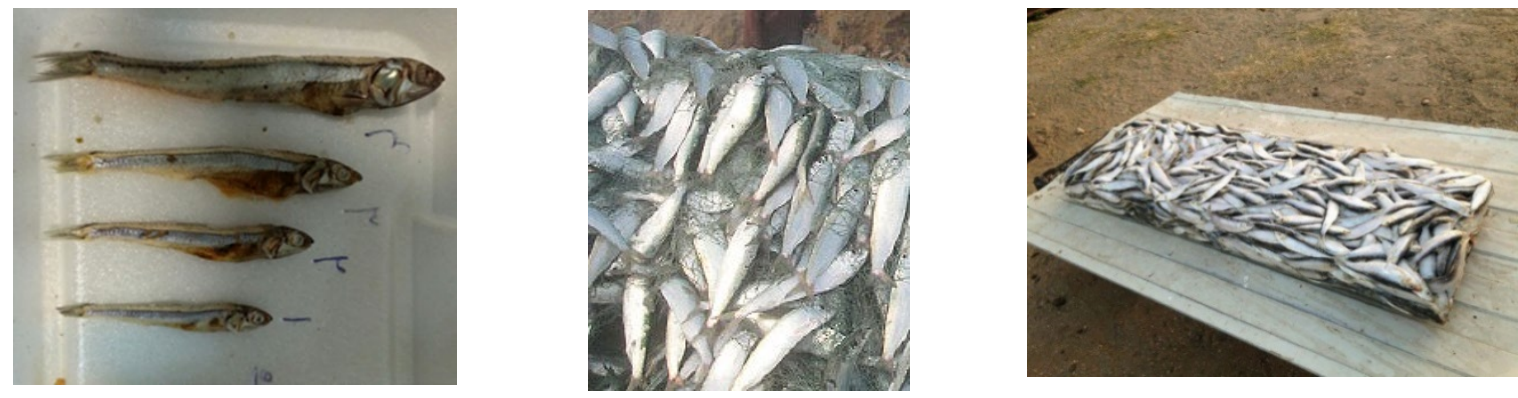

Figure 6 Anchovies (left), sardines (middle) and kilka (right).

\subsection{Plan of action}

To increase the human consumption of anchovy, kilka and sardines in Iran it is necessary to be able to distribute the products over the whole country and thus increase the availability of products with an acceptable shelve life. The latter requires high quality raw material (cooled with ice or fast frozen) and proper processing of the raw material into products the people are willing to buy and pay for. Many different products made from small pelagic species are already on the market elsewhere in the world (e.g. frozen whole, canned whole, canned filleted, canned and smoked, canned with sauce, with olives, marinated, dried, fried, salted, fish sauce, anchovy paste etc.). We therefore suggest to investigate which of the available products made from small pelagic species already on the market elsewhere in the world would the Iranian people (repeatedly) buy and eat. This can be done using consumer research e.g. studying consumer preference and the use of direct market tests to evaluate and screen the different products to learn how consumers and retailers react to handling, using and repurchasing the different products to finally forecast future sales of the products and market potential of the products tested in the distribution territory of Iran. Products with sufficient market potential must be produced and commercialized together with or by the private sector. The knowledge needed to produce and commercialize the specific products needs to be implemented by learning or for example a joint venture with a company already selling such products elsewhere. 


\subsection{Summary}

1. Making an inventory of available products

2. Investigate which of these products the Iranian people accept, (repeatedly) buy and eat

3. The most preferred products with sufficient market potential can be produced using Iranian pelagic species and commercialized in cooperation with or by the private sector 


\section{Increase of the resource use efficiency (RUE) of tuna by products}

\subsection{Introduction}

Currently, most of the tuna by products (head, tail, skin and carcasses) are heat treated and fed to either cow of poultry. The available amount is estimated to be approximately 80000 tons. It is suggested to preserve the tuna by products for aquaculture purposes. The added value of feeding tuna by products to cow is limited as the essential fatty acids (EPA and DHA) are broken down by the rumen fermentation. This is not the case in poultry, were feeding of tuna by products can enrich eggs and meat with essential fatty acids (EFA). However, the use of alternative ingredients in feeds for aquaculture is more of a challenge than in feeds for poultry. A more technological approach for the processing of tuna by-products to increase added value could be to investigate the possibilities for the production of fish oil and a protein based product (e.g. fishmeal or fish hydrolysate).

During the fact finding mission a plan was made in consultation with our Iranian colleagues to increase the resource use efficiency (RUE) of tuna by products.

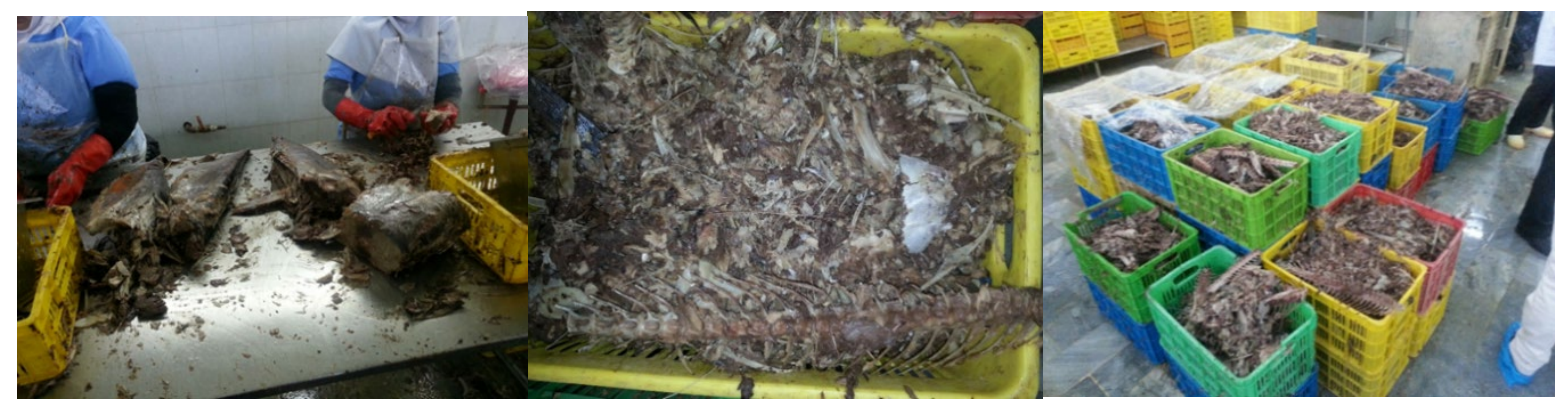

Figure 7 Some impressions of the tuna by products available from the tuna canning industry.

\subsection{Plan of action}

Important for both the quality of the tuna products as the quality of the tuna by-products is to stimulate proper handling on board (e.g. fast freezing). Proper handling will improve the quality of the raw material. To gain insight of the composition and quality of the tuna by products it is suggested to analyse the proximate composition and evaluate the quality of the oil. The latter can be done by extracting the oil on lab scale, preferably using high speed centrifugation, and analyse the fatty acid profile, the free fatty acids, peroxide value, anisidine value and trace elements (e.g. cupper and iron)). If the quantity and quality of the extracted oil obtained from the tuna by products is promising the next step could be building a basic pilot installation for the recovery of the oil and the separation of proteins. At first the focus will be the recovery of oil. Later, one can also focus on the protein fraction and evaluate if the protein fraction can be used for the production of fishmeal or a protein hydrolysate.

\subsection{Summary}

1. Stimulate proper handling on board

2. Proximate composition of by products

3. Lab scale oil extraction from tuna by products

20 | Wageningen Livestock Research Report 1219 
4. Evaluate oil quality

5. If oil quantity and quality is promising than there is a Go, otherwise a No Go

6. Building a pilot installation for oil recovery and the separation of proteins

7. Optimization of production process

8. Refining of extracted tuna oil

9. Processing of proteins (fishmeal or fish protein hydrolysate possibly containing bioactive peptides)

10. When choosing for a hydrolysate one can start with lab scale experiments and progress when promising by building a pilot hydrolysation plant. 


\section{Increase of the use of lantern fish for both fishmeal and human consumption}

\section{$9.1 \quad$ Introduction}

According to the data presented the maximum sustainable yield (MSY) of lantern fish is much higher than the current catch, which is about $15 \mathrm{kton}$ a year. The goal of the Iranian government is to increase lantern fish landings to 100 kton in the next five years. Currently, lantern fish is only used for the production of fishmeal. However, the goal of the Iranian government is to allocate or use $50 \%$ of the landings for human consumption.
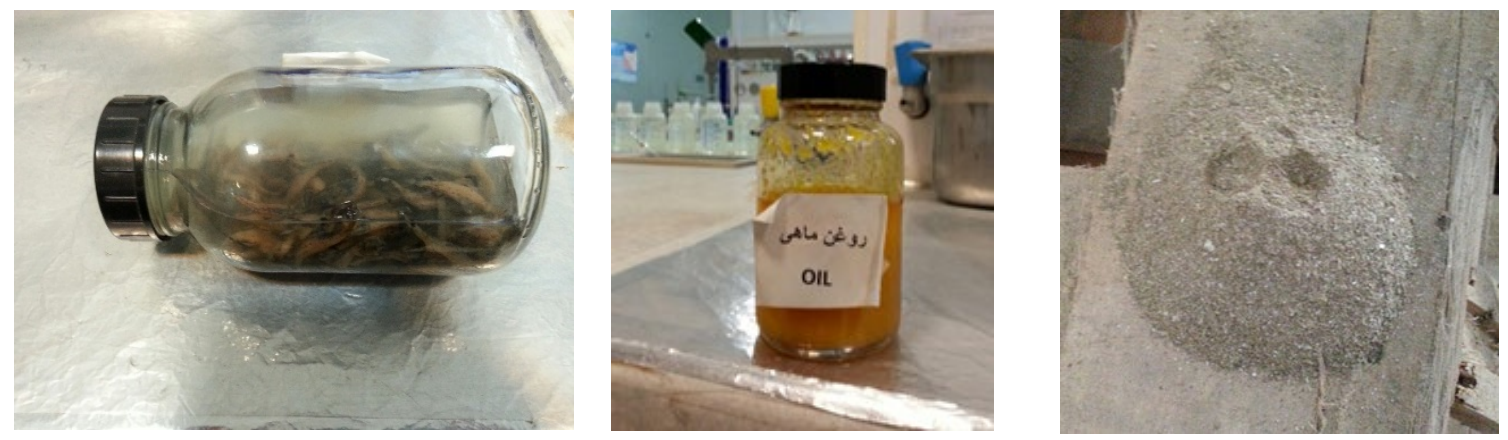

Figure $8 \quad$ Lantern fish (left), fish oil (middle) and fish meal (right) from lantern fish.

\subsection{Plan of action}

As lantern fish is frozen on board it is expected that the quality of the raw material is sufficient for further processing. Though, it is necessary to evaluate if the raw material is suitable for making products appropriate for human consumption. It is suggested to investigate possibilities to separate the oil, protein and bone fraction for example by using the isoelectric precipitation and solubilisation technology with the focus to produce a functional fish protein isolate. From the half fabricates (fish protein isolate, oil and bones), especially the functional fish protein isolate, nutritious products need to be developed that people are (repeatedly) willing to buy and pay for.

Currently, lantern fish is only used for the production of fishmeal. To check the possibility to add value toward this process one can screen the sticky water from the fishmeal production plant for the presence of bioactive peptides.

\subsection{Summary}

1. Evaluate if lantern fish is suitable for making products appropriate for human consumption. Yes means a Go, no means a No Go

2. Development and production of half fabricates and products from lantern fish that people are willing to buy and pay for

3. Commercialisation of developed products by or together with the private sector 


\section{By products of carp}

\subsection{Introduction}

Currently, there is overproduction of carp in Iran, which caused a price drop of carp with the result that farmers are getting into financial problems. The Iranian government is looking for solutions to solve this problem. One of the suggested solutions is to develop anomalous products e.g. meat analogous by using carp (meat) and increase demand.

\subsection{Plan of action}

Investigate the possibilities of using carp (meat) for the production of fish products and or meat analogous to stimulate the demand for carp, which might help to solve the problem of overproduction. For this challenge we refer to the Silver carp project which was running from 2002 to 2006 in cooperation with Iran (Bartels and Kals, 2004; Bartels and Kals, 2007). It is expected that carp meat can serve as a raw material for the products developed during the Silver carp project. If so, the results from that Silver carp project can be used for the development of fish products from carp. In addition, the skin and bones from carp could be used for the extraction of collagen/gelatin. Collagen/gelatin could be interesting products for example in cosmetics. Naturally, as stated earlier, it is wise to study consumer preference and use market tests to screen the products to forecast future sales and market potential in Iran. Only products with sufficient market potential should be produced and commercialized together with or by the private sector.
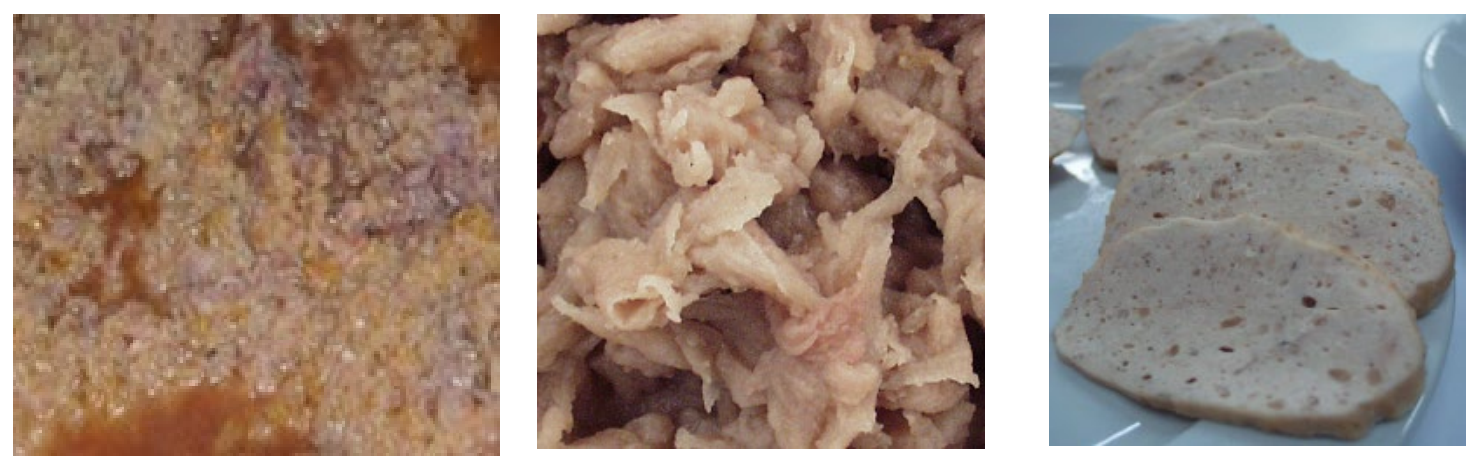

Figure 9 Mince from fresh water bream (left), a meat analogue (middle) and fish "cheese" (right).

\subsection{Summary}

1. Implement the knowledge gained during the Silver carp project using carp (meat)

2. Investigate which products the Iranian people accept, (repeatedly) buy and eat

3. Products with sufficient market potential can be produced and commercialized in cooperation with or by the private sector. 


\section{Follow up field visit and workshop, June 8-13, 2019}

Based on the above recommendations, and as a follow up on the 2017 mission, we proposed to have a seminar and an industry mission to Iran to further explore possibilities for business to business development. Two topics were selected from the 2017 shortlist: item 5) Tilapia breeding programs for brackish water aquaculture in RAS, and item 9) processing of lantern fish. Following consultation with representatives of IFSRI, it was also decided to organize a workshop in Tehran for industry representatives. The mission and workshop took place in June 8-13, 2019. Participants were: dr. Hans Smolders, agricultural attaché, Netherlands embassy, dr. Leon Lomans, ministry of LNV, Netherlands, dr. Jeroen Kals, researcher seafood, aquaculture and fish nutrition Wageningen University, and prof. Hans Komen, Animal breeding and genomics group, Wageningen University.

\section{$11.1 \quad$ Tilapia farming}

The mission started in Shiraz with visits to a trout farm and hatchery, and a sturgeon farm. This was followed by a visit the next day to the Bafqh Research Center of Saline Water Aquatics in Yazd province, where tilapia is cultured in brackish water conditions. In 2018, Iran was the fourth biggest importer of tilapia, importing more than 60.000 tonnes of tilapia from China. The Iranian government subsequently imposed restrictions on imports, in an effort to protect and boosting domestic aquaculture production. In 2018, the total production of tilapia was still limited to 2000 tons by only two farms in Iran. Based on the positive research outcomes, and the Bafgh centre developing into a fry farm to serve the aquaculture industry, the Iran Department of Environment issued permission for tilapia cultivation to three more provinces, including South Koresan, Semnan and Qom. As these provinces have similar conditions like Yazd, these areas are considered safe to produce. The enthusiasm among aquaculture farmers is high. Since 2018, more than 32 farms successfully received permission to cultivate tilapia in the four provinces. It is planned to produce 50.000 tons of tilapia by 2023. Meanwhile, import is continuing on a $35 \%$ import tariff based on local demand. The research center in Bafgh is spearheading research on the practical implementation of tilapia aquaculture. The centre is also responsible for providing fish farms with tilapia fingerlings. In 2018, and early 2019 demand was larger than supply, and the director of the centre expressed strong concerns regarding the fingerling producing capacities.

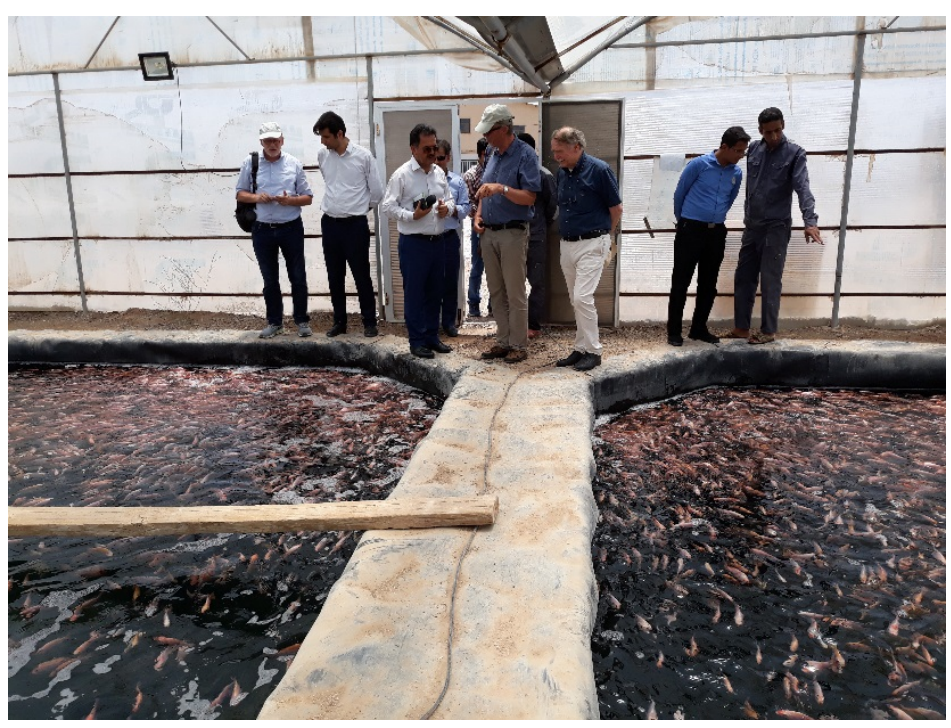

Figure 10 Visit to Bafgh research center. 
Low night-time temperatures are a constraint to farming tilapias and other warm water species in much of Iran, though this might also mitigate against escapees surviving. Even in the desert areas where daytime temperatures can go to $50 \mathrm{C}^{\circ}$ or above, the minima can be as low as $-10 \mathrm{C}^{\circ}$. At Bafgh, a greenhouse pond system is used that pumps up brackish groundwater (15ppt; about $24 \mathrm{C}^{\circ}$ ) which allows for an 8-month growing season, or perhaps year-round with further development, and puts out very little effluent. This also effectively prevents fish from escaping. Dutch aquaculture industry is well known for their expertise in design and building recirculating aquaculture systems (RAS). Several companies offer these services to clients worldwide. Unfortunately, due to the economic sanctions, none of these companies were able to join the current mission. In addition, one company (TilAqua) that specializes in breeding all male tilapia fry for export is currently in the process of being taken over by a larger breeding company with vested US interests. The mission therefore focussed on the development of a pilot project to design a simple robust breeding program for brackish water tilapia production. Ideally, and when the economic sanctions are lifted, a public-private partnership should be developed where Dutch companies that offer RAS technology, are invited to participate.

Following the visit to Bafgh, a short debriefing meeting took place with the deputy governor and the director of AREEO, of Yazd province. During that meeting, the deputy director expressed his support for a collaborative program on sustainable aquaculture. It was agreed that Wageningen and IFSRO would look into possibilities for future collaboration.

\subsection{Seminar and workshops June 12th}

The Seminar Programme, entitled "Netherlands - Iran seminar on sustainable aquaculture" took place on Wednesday 12th of June, 2019, at the Conference Hall of AREEO, Teheran. The complete program is given in appendix 1 . The workshop was officially opened by the head of IFSRO. The plenary session was entitled: "Developments in sustainable aquaculture from Iran and global perspective", with contributions from mr. Leon Lomans (minLNV): Development of fish cultivation from global and European perspective, IFO: Policies on sustainable aquaculture development in Iran, and the Fisheries Union, chamber of commerce: Iran Fisheries Overview.

The opening session was followed by a series of 6 parallel workshops on breeding programs (seabass \& tilapia; Komen), fish processing and value chain (Kals), EU trade and ASC/MSC certification (van Daetselaar), consumer preferences (mrs. Gemma Tacken, WUR) and sea trade intelligence platforms (STIP; Sander Visch). The seminar was followed by a debriefing meeting organized by the Dutch embassy with the director and members of IFPRO, where follow up actions were discussed.

The session on aquaculture was very well attended with over 40 participants. Questions from audience focussed on practical and technical issues related to production and reproduction of Asian seabass and bream in the Persian gulf, ) and cost effectiveness of using RAS technology in Iran. A larger part of the discussion centred on the prospects of tilapia farming in Iran. A main emerging theme in these discussions was the availability of good quality fry for basically all aquaculture species, and the continuing dependence on imports of eggs and fry from other countries. Breeding programs were seen as a solution but adoption is difficult due to lack of training in basic concepts of animal breeding. The presentations given on the workshop of breeding programs are attached in appendix 4. 
The session on fish processing and value chain as the session on consumer preferences were well attended. People were standing as all chairs were occupied. Interesting was that the major part of the participants were women. During the processing session the results of the fact finding mission of 2017 , especially the topics identified during the mission and the corresponding plans of actions, which are described in chapter seven to ten of this report, were briefly discussed. In addition, seven topics (Figure 11) were presented in the order preferred by the participants. The topics related to the production fish hydrolysates, bioactive peptides and meat analogues initiated the most discussion also thanks to the presence a research colleague from the Animal Science Research Institute of Iran (ASRI) who himself published research on the developments of products e.g. meat analogues from Lantern fish. Participants were also interested in techniques for modifying texture, bite, mouthfeel and using emulsion technology to produce oil enriched fish products. The presentations given during the processing workshop are attached in appendix 2.

The session on consumer preference given by Gemma Tacken focused on the results of the European project Diversify; "perspectives for selling to the European fish market". Topics discussed were market analysis, new product development, consumer perceptions and behavioural change, consumer communication and business model and market development strategies. The approach of Diversify is shown in figure 12 . The presentation given is attached in appendix 5 of this report.

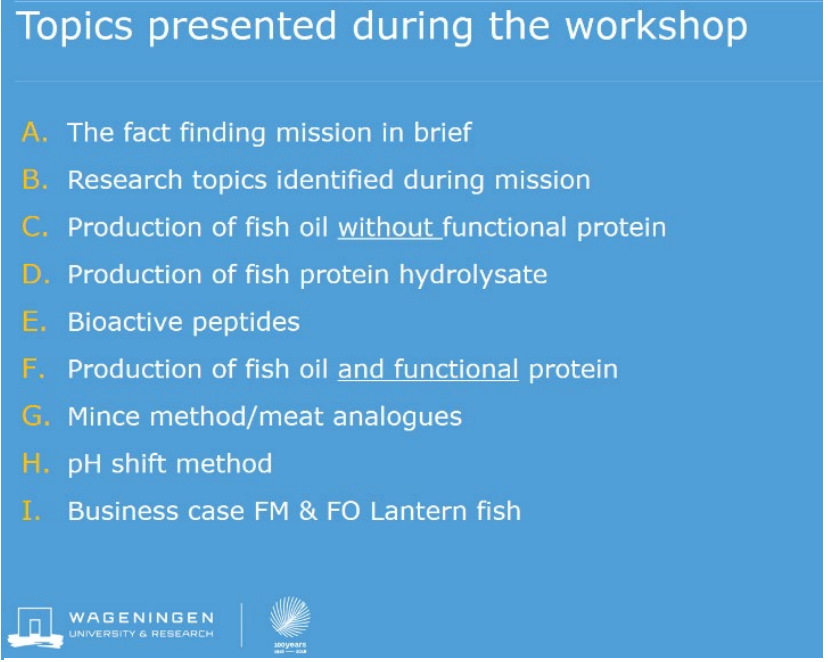

Figure 11 The topics presented and discussed during the processing workshop.

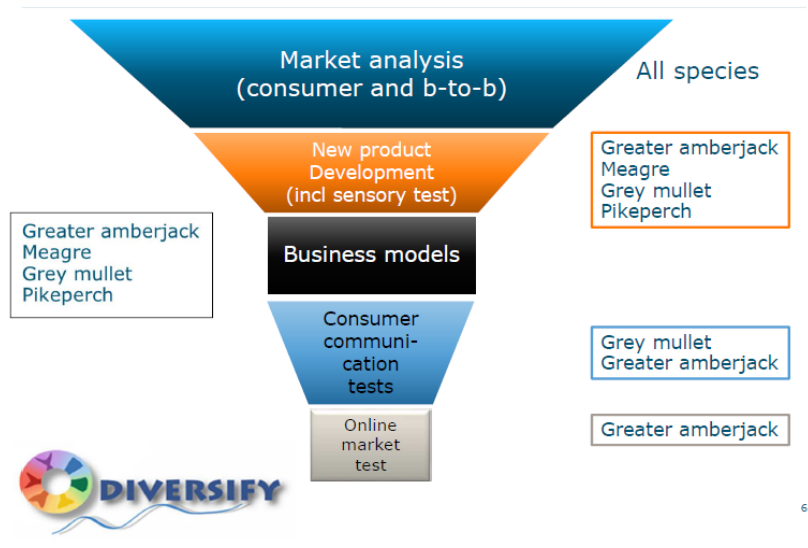

Figure 12 The funnelling approach used in the project Diversify. 


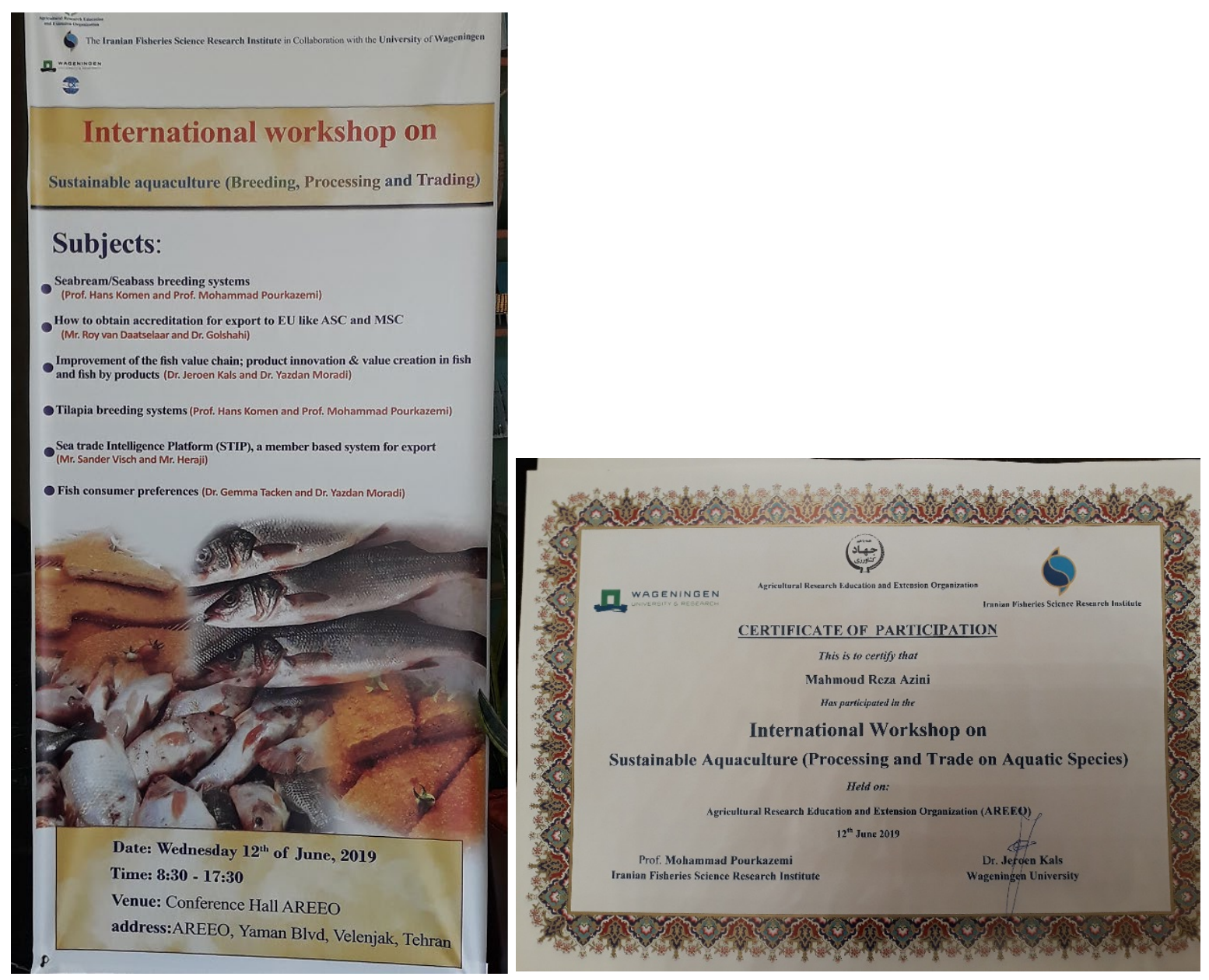

Figure 13: Poster of the International workshop on sustainable aquaculture and Certificate of attendance.

At the end of the conference the Tilapia and Lantern fish project were mentioned as the two main priorities for Join Research and Pilot Projects (slide: "Future plans to have Joint projects", projected on the back of the group picture, figure 14). During the final debriefing after the conference, the various options for continued collaboration were discussed. Prof Komen again emphasized the availability of grants for the European master program EMABG, where students can receive training in Animal breeding and Genetics, and the director of IFSRO agreed to advertise this possibility among the Iranian universities. PhD training outside Iran was not considered an option for capacity building as there is no guarantee that candidates will return to Iran after they have received their doctoral degree. The possibility for Iranians to follow an open online course on animal breeding through EdX.org is currently blocked by the US government.

Wageningen university and research is currently not in favour of deploying staff for training courses in Iran, and financial instruments that allow remuneration of WUR staff are lacking.

In a final meeting with representatives from the Bafgh station, and the director of IFSRO, a follow up project on tilapia farming, focussing on breeding and use of RAS technology, was discussed.

The Lantern fish project was discussed with the director of IFSRO and two IFSRO research colleagues. IFSRO was determined to start with the project as soon as possible. Yet, the major bottleneck to start the project appeared to be the restrained position of the private sector due to the economic sanctions. Dr. Kals emphasized that the intended production of fish meal (protein) and fish oil (essential fatty acids) from Lantern fish could support the growth of an Iranian tilapia culture industry up to a production of 150.000 ton year, making Iran self-sufficient on fish meal and fish oil for their tilapia culture plans, assuming the non-marine feed ingredients are readily available. 
All participants agreed that there were good prospects for a commercially successful follow up program. Such a plan will need funding from the Iranian counterpart for Iranian activities, and from NL parties that would support the technical input from Dutch experts.

In conclusion, the seminar was very successful and attracted over 150 attendants equally from private industry and from research organisations, and was very positively reviewed. There were sometimes lively debates, and there was a lot of interaction among the participants themselves. All participants received a certificate of attendance. The list of participants is not part of the appendix due to privacy reasons. 


\section{Conclusions}

The persons involved in the mission have the opinion that the Islamic Republic of Iran has great potential to increase aquaculture production/products in Iran through the development of breeding programs for new and existing species. There are also many opportunities to increase the added value and resource use efficiency of by-products of fish processing and the use of underutilised fish species. The findings outlined in this report together provide a good overview of the possibilities for joint cooperative projects on the priority areas in the coming years. Species with high potential/perspectives for further development of the Iranian aquaculture sector are tilapia and marine species like shrimp and seabass. For processing, the increase of the human consumption of small pelagic species, resource use efficiency of tuna by products and the top priority the increase of the use of lantern fish for both fishmeal and human consumption are very promising. Of which the latter goes hand in hand with boosting sustainable aquaculture and create win-win situations in the Iranian fish value chain.

Yet, the execution of the plans of action for joint research and cooperation has to be made concrete by the involvement of both IFSRO, AREEO and the private sector. The involvement of IFSRO is crucial for capacity building, especially with regard to animal breeding. The private sector, with support from AREEO is crucial for funding, production and commercialisation of the products developed. Below we give a short summary of the current state of affairs at the time of finalizing this report (end 2019).

Training: Currently the only training instrument available is the EMABG master program in animal breeding. Grants are available on a competitive basis and Universities will be more actively informed and stimulated to encourage high potentials to apply. Online training courses are currently not available as the hosting platform EdX is controlled by the US government. PhD training is currently not favoured by the Iranian government due to the low return rate of graduates (brain drain).

Caspian trout: an Iranian PhD student has been working on this species, but without support from Dutch knowledge institutes other that an occasional answering of email with detailed technical questions.

Seabass: no further action will be taken. Import of fry from Australia will continue as they are the only supplier. A Dutch farm in Singapore is currently starting a breeding program, but has no immediate interest to expand its activities to Iran.

Tilapia: due to an emerging strong demand for locally produced tilapia, and the availability of large areas for brackish water aquaculture, there appears to be a match for IR-NL joint programs on this species. A Dutch feed company, currently active in the Iranian poultry market, has the resources and knowhow to set up a feed supply for tilapia in case the tilapia industry develops into a commercially viable proposition. Tilapia farming in desert areas that have become unsuitable to other types of farming due to climate change and overexploitation of fresh water resources, could provide new income and labour opportunities for poor areas with high unemployment rates, especially under young people, as well as cheap and nutritious food for vulnerable households, pregnant women and children. The aim is to continue to explore funding opportunities that could support a public-private technical program devoted to the development of tilapia farming.

Lantern fish: In Autumn 2018 dr. Kals was invited by IFSRO to write a quotation for the joint research project: "Improvement of the fish value chain in Iran: value creation in fish and fish products", which was based on the results of the fact finding mission in 2017 and research priorities given by Iran (appendix 3). During a Skype meeting in February 2019 with the director of IFSRO, IFSRO research colleagues, dr. Hans Smolders the Dutch agricultural attaché, dr. Kals and WUR research colleagues it was decided for the processing part to focus on the processing of Lantern fish. A new proposal: "Improvement of the fish value chain in Iran: Increase of the use of lantern fish for both fishmeal and human consumption phase 1", was written and discussed with IFSRO during our meeting at AREEO, Teheran in June. IFSRO was determined to start with the project as soon as possible.

Win-win tilapia culture and Lantern fish (appendix 6): Interesting is the potential connection between the Lantern fish project and the development of a large scale tilapia industry in Iran. The goal of Iran is to produce 50.000 tons of tilapia per year by 2023 . For Lantern fish the goal of Iran is to increase the 
landings of Lantern fish to 100 kton per year of which $50 \%$ will be allocated for the production of fishmeal and fish oil. This will make Iran self-sufficient on fish meal and fish oil up to a yearly tilapia production of 150.000 tons, three times the currents ambition, assuming the non-marine feed ingredients are available.

However, at the time of writing this report, the economic sanctions imposed on Iran by the US government, are still in force. As a result, Dutch industry partners in aquaculture technologies (RAS) are not willing to invest time and effort in exploring business opportunities. Business is further frustrated by sanctions imposed by banks that have vested interests in the US, and lack of alternative payment instruments. As a result, very little economic activity can be employed at the moment. The sanctions are also having a large economic toll on the Iranian government, which makes it very difficult for them to engage in large co-financed projects with WUR. Despite these current setbacks, we strongly believe that Dutch aquaculture and processing industry in a PP setting with e.g. WUR can play an important role in future development of the Iranian fish value chain for both wild and farmed fish. 


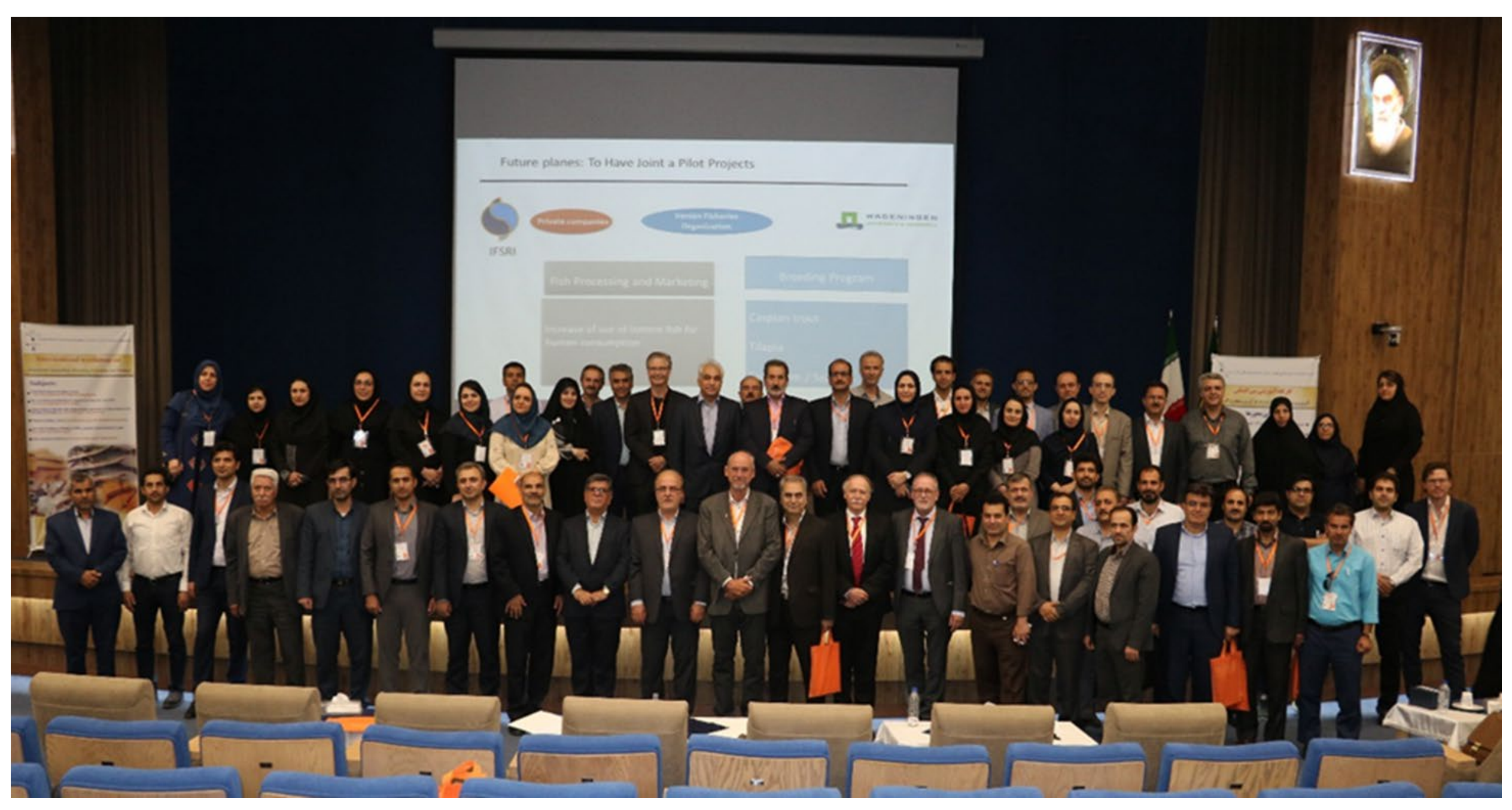

Figure 14 A group picture of the seminar attendants. 


\section{References}

- $\quad$ Bartels, P. and J. Kals. Improving the utilization of Silver carp (Hypopthalmichthys Molitrix) and or other under-utilized fish species, especially Fresh water Bream (Abramis brama). Possibilities for value adding supply chains and international trade of Silver carp (Hypopthalmichthys Molitrix) in the Islamic Republic of Iran. Final report of the research 2005-2007. Rapport nr. 767

- Bartels, P. and J. Kals. Improving the utilization of Silver carp (Hypothalmichthys molitrix) and or other under-utilized fish species, especially Fresh water Bream (Abramis brama) 2005 2006 : possibilites for value adding supply chains and international trade of silver carp (Hypothalmichthys molitrix) in the Islamic Republic of Iran. Report C006B/06

- Data sources from planning and budget directorate of Iranian fisheries organisation

- El-Mowafi, A \& Berntssen, M.H.G (2010) Evaluation of lantern fish (Benthosema Pterotum) as marine source in fish feeds: nutrient composition and contaminants assessment. Proc. of the 3rd Global Fisheries \& Aquaculture Research Conference. Foreign Agricultural Relations (FAR), Egypt, 29th Nov. - 1st Dec., (2010) pp. 12 - 23

- $\quad$ FAO publications related to aquaculture in Iran.

- FAO Fisheries and Aquaculture Information and Statistics Branch Regional Aquaculture Information System

- $\quad$ Fishmeal prices https://www.indexmundi.com/commodities/?commodity=fishmeal\&months $=60$

- $\quad$ Fish oil prices https://www.statista.com/statistics/762335/fish-oil-price-worldwide/)

- IFFO From http://www.iffo.net/

- Shahidi, F. (2007). Maximising the value of marine by-products CRC Press, 978-0-8493-91521 , St. Johns, Canada

- Shaviklo \& Rafipour. Surimi and surimi seafood from whole ungutted mucophid mince. Food Science and Technology 54 (2013) 463-468.

- The Iranian Fisheries Organisation. 


\section{Appendix 1 Workshop program Tehran 12 June 2019}

\section{Seminar Programme}

\section{Netherlands - Iran seminar on sustainable aquaculture}

Wednesday $12^{\text {th }}$ of June, 2019

Venue: Conference Hall AREEO, address: Yemen Blvd, Velenjak, Teheran

\begin{tabular}{|c|c|c|}
\hline \multicolumn{3}{|c|}{ Morning Session (Fajr Hall) } \\
\hline Time & Programme \& theme & Speakers \\
\hline 8:30-9:00 & Registration & \\
\hline 9:00-9:20 & Welcome and Opening & $\begin{array}{l}\text { - Head of IFSRI, Dr. Pourkazemi (10 min) } \\
\text { - } \text { Agricultural Counselor, the Netherlands Embassy, } \\
\text { Mr. Hans Smolders (10 min) } \\
\text { - Moderator: Prof Valinassab }\end{array}$ \\
\hline 9:20-9:30 & $\begin{array}{l}\text { Video on sustainable fish } \\
\text { production }\end{array}$ & \\
\hline $\begin{array}{l}9: 30- \\
11: 00\end{array}$ & $\begin{array}{l}\text { Developments in } \\
\text { sustainable aquaculture } \\
\text { from Iran and global } \\
\text { perspective }\end{array}$ & $\begin{array}{l}\text { Leon Lomans or Prof Hans Komen, Wageningen } \\
\text { University \& Research: Development of fish } \\
\text { cultivation from global and European perspective } \\
\text { ( } 20 \text { min) } \\
\text { Dr. Abdolhai (IFO): Policies on sustainable } \\
\text { aquaculture development in Iran ( } 20 \mathrm{~min}) \\
\text { Dr. Khodaei (Fisheries Union, chamber of } \\
\text { commerce): Iran Fisheries Overview ( } 20 \mathrm{~min} \text { ) }\end{array}$ \\
\hline $\begin{array}{l}11: 00- \\
11: 30\end{array}$ & Coffee/ tea Break & \\
\hline
\end{tabular}

\begin{tabular}{|c|c|c|c|}
\hline \multicolumn{4}{|c|}{ Parallel Workshop - Morning Sessions } \\
\hline Time & Fish breeding & $\begin{array}{l}\text { Domestic and export } \\
\text { market }\end{array}$ & $\begin{array}{l}\text { Fish processing and } \\
\text { consumer preferences }\end{array}$ \\
\hline \multirow{2}{*}{$\begin{array}{l}11: 30- \\
13: 00\end{array}$} & Fajr Hall & Andisheh Hall & Danesh Hall \\
\hline & $\begin{array}{l}\text { Workshop 1: } \\
\text { Seabream/Seabass } \\
\text { breeding systems } \\
\text { Key speaker: Prof Hans } \\
\text { Komen } \\
\text { Moderator: Prof } \\
\text { Pourkazemi (IFSRI) }\end{array}$ & $\begin{array}{l}\text { Workshop 2: How to } \\
\text { obtain accreditation for } \\
\text { export to EU like ASC and } \\
\text { MSC" } \\
\text { Key speaker: Roy van } \\
\text { Daatselaar TBD (Skype) } \\
\text { Moderator: Dr. Golshahi }\end{array}$ & $\begin{array}{l}\text { Workshop 3: Improvement } \\
\text { of the fish value chain; } \\
\text { product innovation \& value } \\
\text { creation in fish and fish by } \\
\text { products. } \\
\text { Key speaker: Dr. Jeroen Kals } \\
\text { Moderator: Dr. Moradi }\end{array}$ \\
\hline $\begin{array}{l}13: 00- \\
14: 30\end{array}$ & Lunch \& matchmaking & \multicolumn{2}{|c|}{ Boots or tables available for presentation/brochures } \\
\hline \multicolumn{4}{|c|}{ Parallel Workshop - Afternoon Sessions } \\
\hline
\end{tabular}




\begin{tabular}{|c|c|c|c|}
\hline $\begin{array}{l}14: 30- \\
16: 00\end{array}$ & $\begin{array}{l}\text { Workshop 4: Tilapia } \\
\text { breeding systems } \\
\text { Key speaker: Prof Hans } \\
\text { Komen } \\
\text { Moderator: Prof } \\
\text { Pourkazmi (IFSRI) }\end{array}$ & $\begin{array}{l}\text { Workshop 5: Sea trade } \\
\text { Intelligence Platform } \\
\text { (STIP), a member based } \\
\text { system for export } \\
\text { Speaker: : Sander Visch } \\
\text { (skype } \\
\text { Moderator: Mr. Heraji } \\
\text { (private sector) }\end{array}$ & $\begin{array}{l}\text { Workshop 6: Fish } \\
\text { consumer preferences } \\
\text { Key speaker: Dr Gemma } \\
\text { Tacken (skype) } \\
\text { Moderator: Dr. Moradi }\end{array}$ \\
\hline $\begin{array}{l}16: 00- \\
16: 15\end{array}$ & \multicolumn{3}{|l|}{ Coffee/ tea Break } \\
\hline $\begin{array}{l}16: 15- \\
17: 00\end{array}$ & \multicolumn{3}{|c|}{$\begin{array}{l}\text { Feedback from workshops and matchmaking } \\
\text { Moderator: Hans Smolders, Netherlands Embassy }\end{array}$} \\
\hline $\begin{array}{l}17: 00- \\
17: 15\end{array}$ & \multicolumn{3}{|c|}{ Closing Ceremony } \\
\hline
\end{tabular}


Appendix 2: Presentations processing workshop 
Improvement of the fish value chain in Iran;

product innovation \& value creation in fish and fish products

Results of the fact finding and goal establishing mission to the Islamic Republic of Iran

June 2019, Jeroen Kals

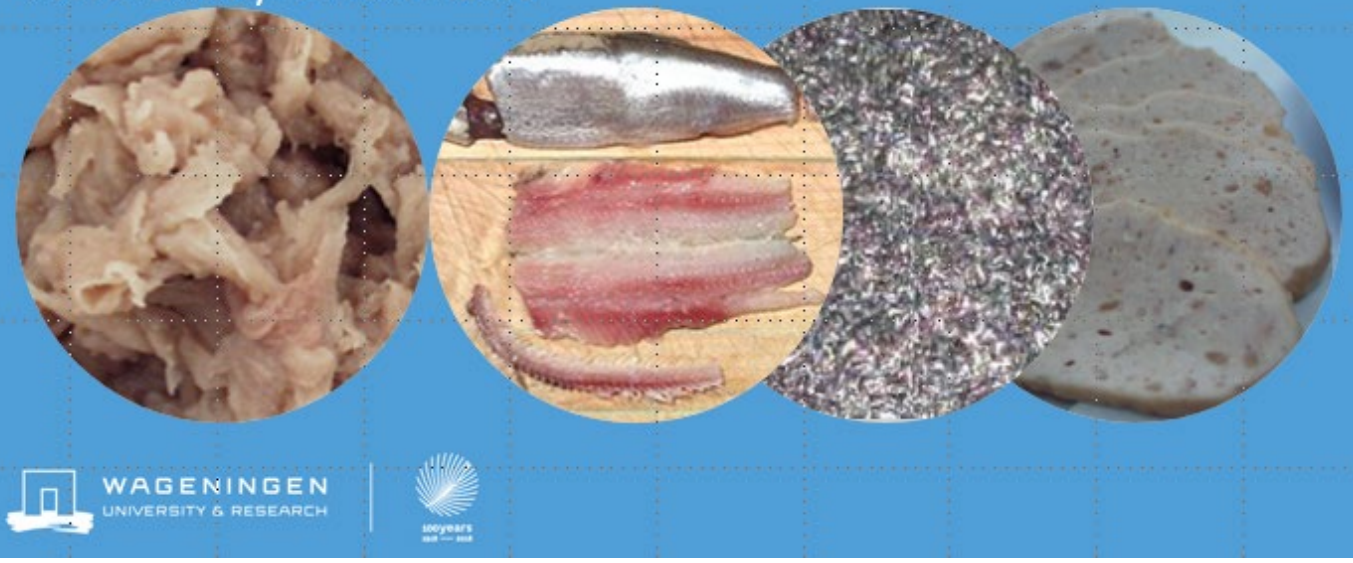

\section{Topics for the workshop}

- Introduction

- The fact finding mission in brief

- Research topics identified during mission

A. Production of fish oil without functional protein

B. Production of fish protein hydrolysate

C. Bioactive peptides

D. Production of fish oil and functional protein

E. Mince method/meat analogues

F. pH shift method

G. Business case FM \& FO Lantern fish 


\section{Topics for the workshop}

Are there shared preferences for the order of topics? For example first topic D, E, and F followed

by topic $A, B$ and $C$ ?

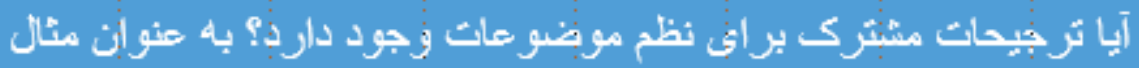

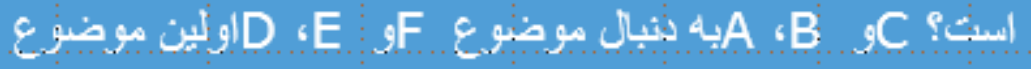

Or will I present the topics in the suggested order?

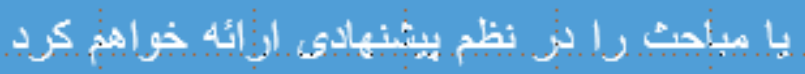

\section{Jeroen Kals}

\section{Study}

- Aquaculture, fish nutrition \& fish processing

\section{Expertise/Work}

- Processing of aquatic by products

- Aquaculture \& Fish nutrition (PhD)

- Testing additives/ingredients

- Development of tailor made feeds

- Training /background

\section{Slogan \& USP}

- Using nature and tech:nology to find a solution

- Ingredients $\Leftrightarrow$ processing $\Leftrightarrow$ rutritional value
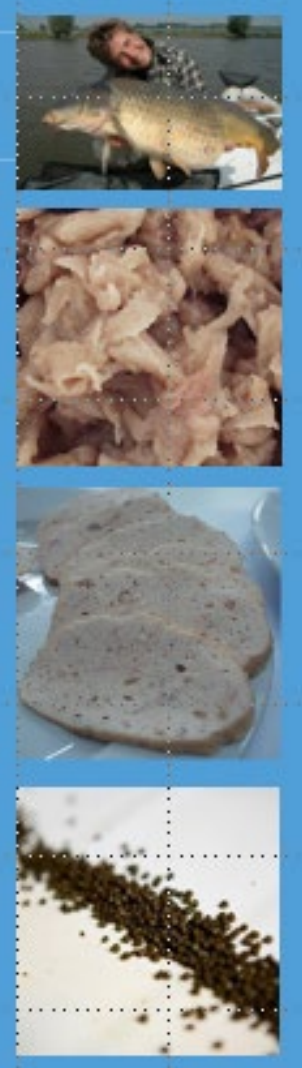


\section{Introduction/background}
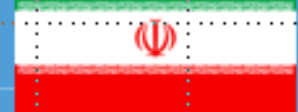

- In Vision 2025 Iran indicates the wish to diversify the economy and become less dependent on the oil industry

- Food security including improvement of nutrition is a top priority that needs to be improved by increasing the productivity of the agricultural, aquaculture and fisheries sector

- Achieved by:

a more efficient aquacuiture industry

processing of fish and by products of fish to high-quality products

WAEENINGEN

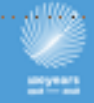

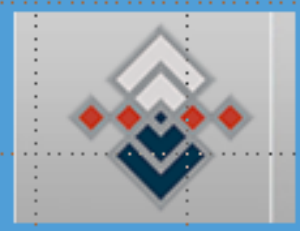
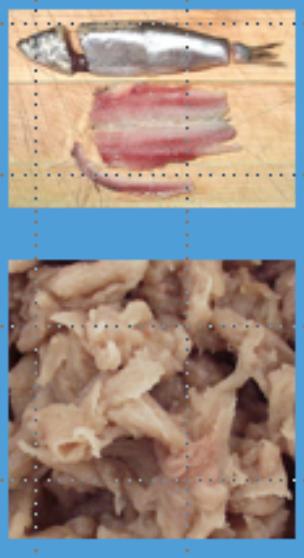

The fact finding mission in brief

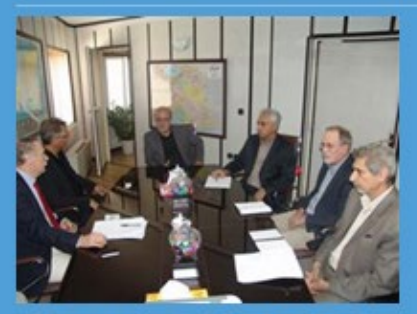

Meeting at IFSRO

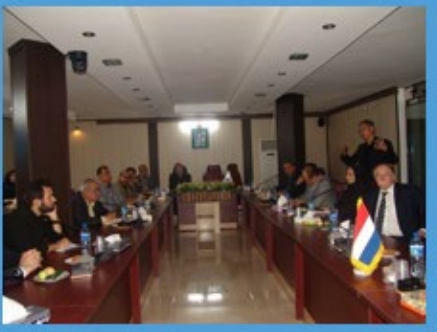

Processing workshop WAGENINGEN
UNIVERSITY G RESEARCH

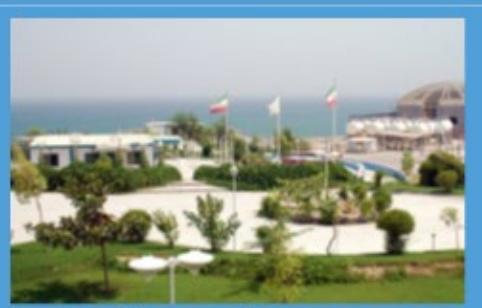

Qeshm Fish Process Company

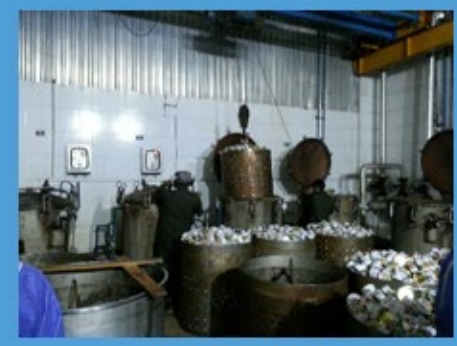

Tuna cannery

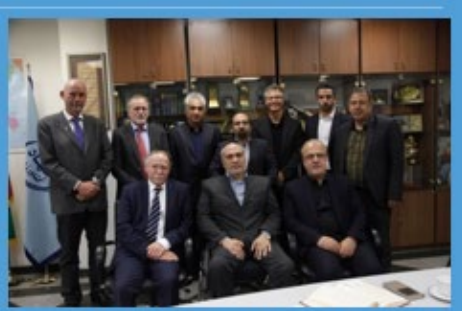

Meeting with the Deputy Minister

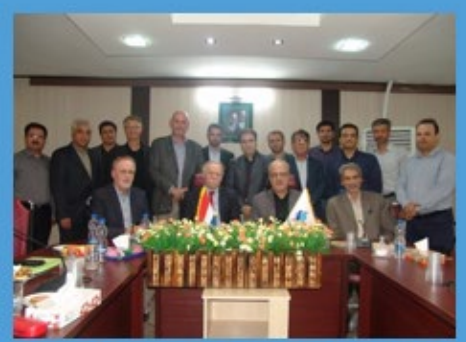

closing of the meeting 


\section{Research topics identified during mission}

For fish processing four objectives are identified:

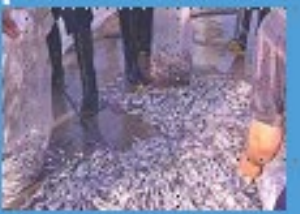

1. Increase human consumption of small pelagic species (anchovy, kilka, sardines)

2. Increase resource use efficiency of tuna by products

3. Increase the use of lantern fist for both fishmeal and human consumption

4. Development of products using carp as a raw material

For each goal a brief introduction and suggested plan of action: is described
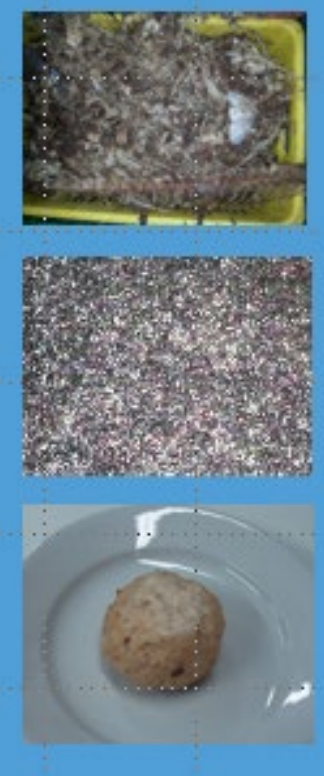

\section{Increase human consumption of small pelagic} species

- Catch 100 kton. $y^{-1}$ only $10 \%$ used for human consumption

- Pelagics high nutritional value

- Direct human consumption $=>$ increase in efficiency of factor 4 by going down in trophic level
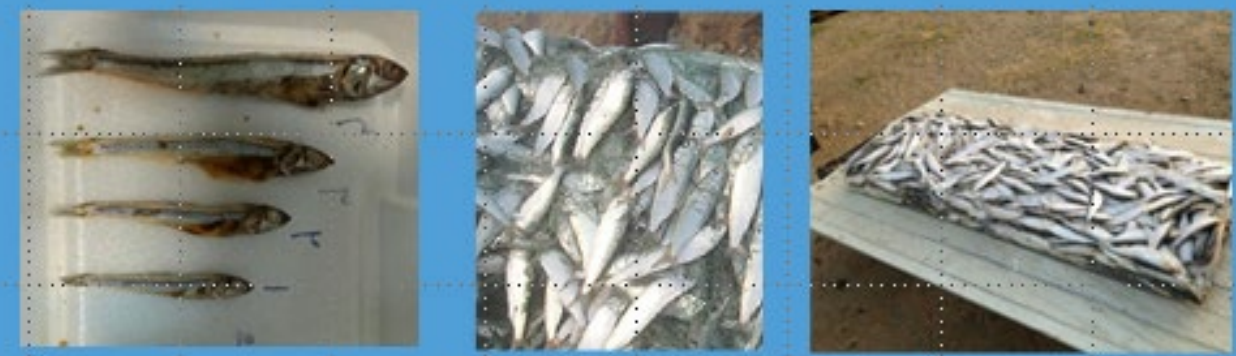

Anchovies (lett), sardınes \{mıddle \} and kıka (rıght)

WAEENINEEN

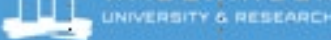




\section{Increase human consumption of small pelagic}

species

\section{Plan of action:}

1. High quality raw material

2. Proper processing raw material into products

3. Making an inventory of avalilable products

4. Investigate which of these products the Iranian people accept, (repeatedly) buy and eat

5. Most preferred products with sufficient market potential can be produced using Iranian pelagic species and commercialized in couperation with of by the private sector WAEENINEEN
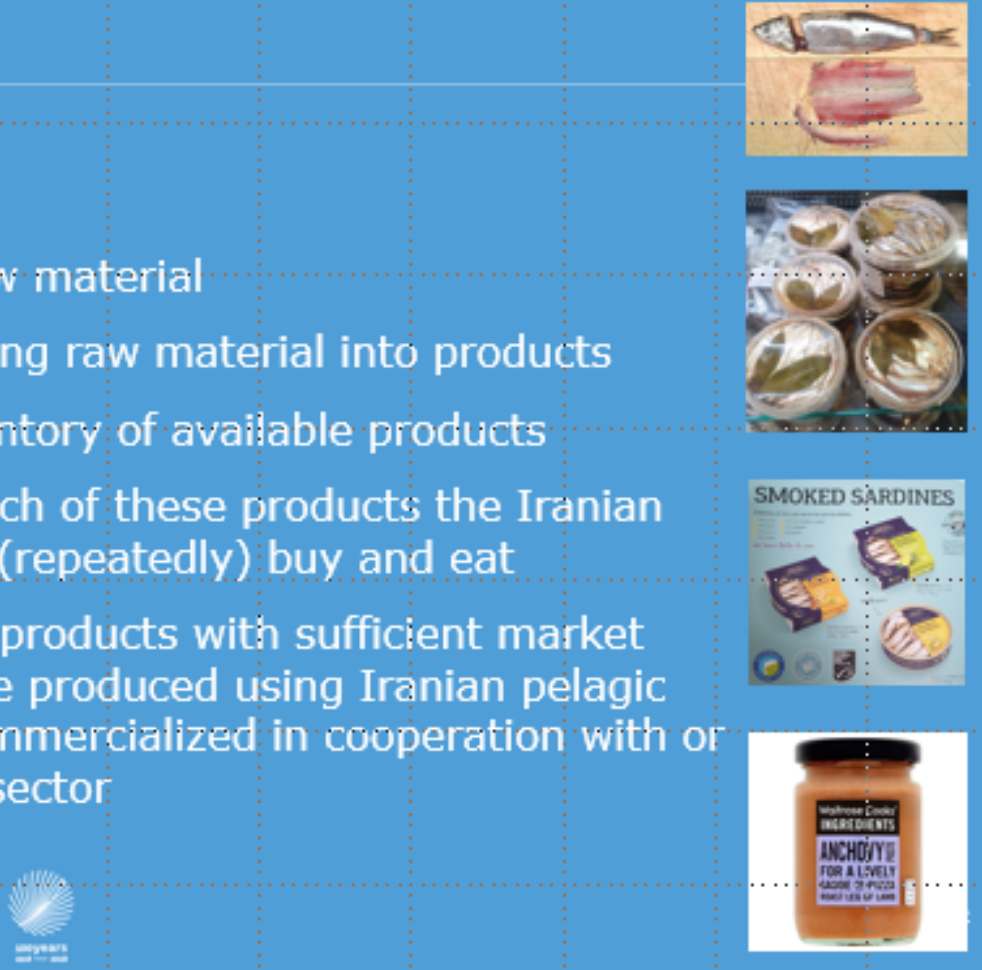

\section{Increase resource use efficiency tuna} by products

- Tuna by products \pm 80 ktons. $^{-1}$

- Currently heat treated and fed to cow or poultry

- Use in aqua feeds higher added value

- Suggestion: investigate production of tuna oil and protein (fish meal or hydrolysate).

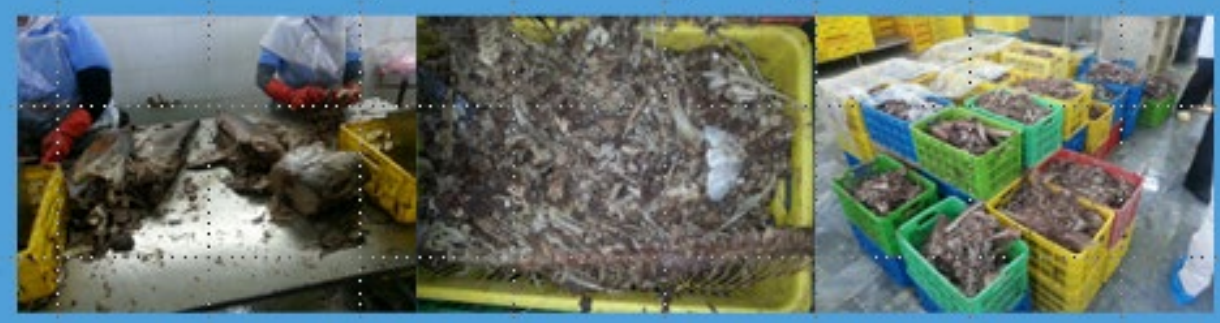

impression or tuna dy proaucts avalladie rrom tne tuna canning

DAGENINGEN industry 
Increase resource use efficiency of tuna by products

\section{Plàn of action}

1. Stimulate proper handling on board

2. Lab scale oil extraction and quality evaluation

3. Oil quantity \& quality promising than Go

4. Pilot installation for recovery of oil and proteins

5. Optimization of production process

6. Refining of extracted tuna oil

7. Processing of proteirs (tuna meal or hydrolysate)

D. WAEENINGEN

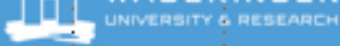
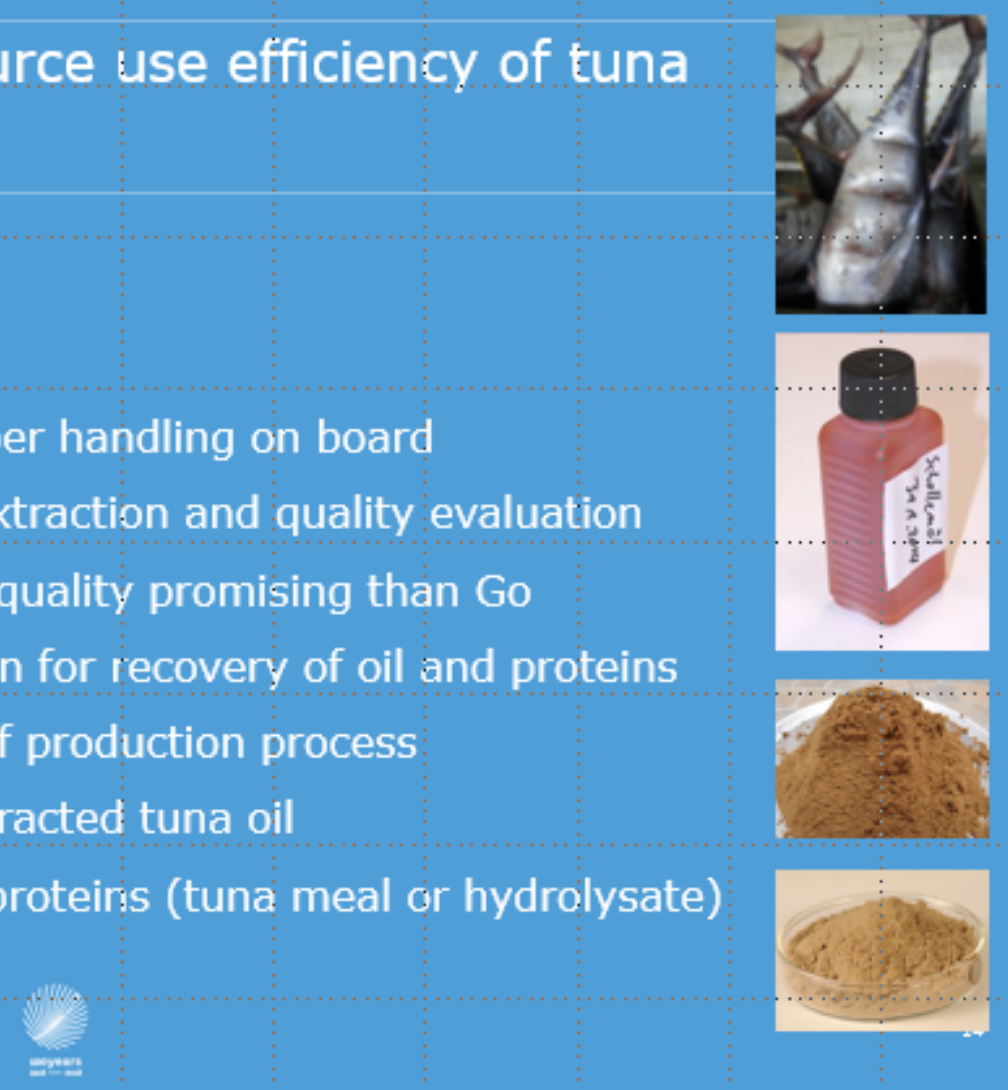

Increase use of lantern fish for both fishmeal and human consumption

- Iranian data: MSY lantern fish $\geq$ current catch (15 kton. Y $^{-1}$ )

- Goal: increase landings to 100 kton. $y^{-1}$ next 5 years

- Allocation: 50\% fishmeal and 50\% human consumption
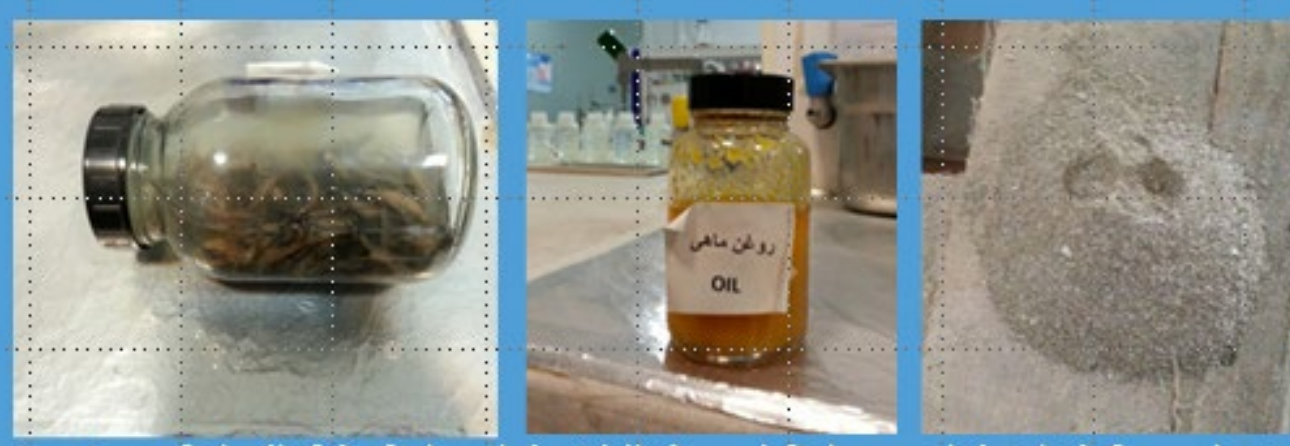

Lantern fish (left), fish oil (middie) and fish meal (right) from lant

D WAGENINEEN 


\section{Increase use of lantern fish for both fishmeal and human consumption}

\section{Plàn of action}

1. Lantern fish is frozen on board quality raw material sufficient for further processing

2. Evaluate if lantern fish is suitable for making products for human consumption. If yes a $\mathrm{Go}$

3. Development \& production half fabricates and products

4. Commercialisation of developed products by or together with the private sector
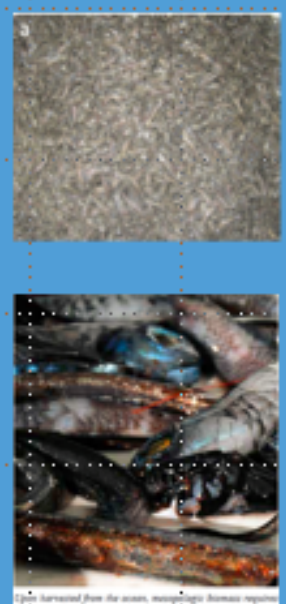

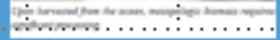

Increase use of lantern fish for both fishmeal and human consumption

\section{Plàn of action}

1. Lantern fish is frozen on board quality raw material sufficient for further processing

2. Evaluate if lantern fish is suitable for making products for human consumption. If yes a Go

3. Development \& production half fabricates and products

4. Commercialisation of developed products by or together with the private sector

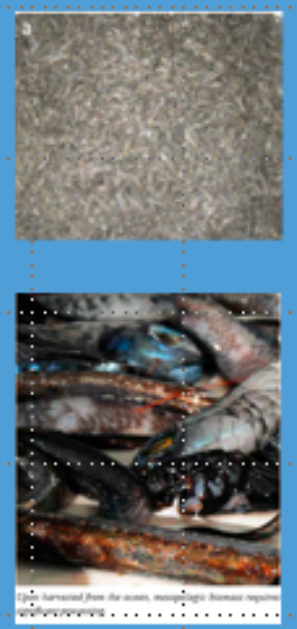




\section{Using carp (meat) for production of meat analogous to stimulate demand for carp}

Plate of action

1. Implement knowledge from Silver carp project

2. Investigate which products Iranian people accept, (repeatedly) buy and eat

3. Products with market potential commercia:ized in cooperation with or by the private sector

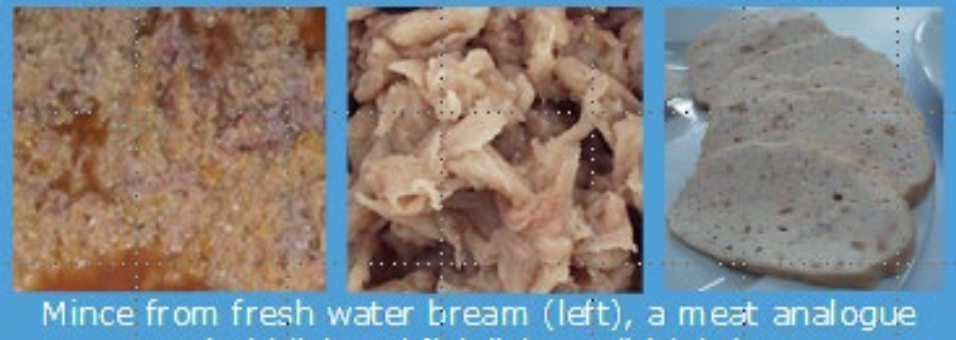

(middle) and fish "cheese" (right).

\section{Recent priority Islamic Republic of Iran}

- Increase use of lantern fish for both fishmeal, fish oil and human con:sumption

- First suggested stepwise approach:

1. Evaluation quality raw materials \& processing chain

2. Small scale production of raw fish oil from lantern fish

3. Improve quality oil by hygienic and/or logistic measures

4. Refining raw fish oil

5. Small scale production of protein of significant quality in terms of nutritional value and/or technical functionality

6. Production of oil and protein on pilot scale 


\section{Increase use of lantern fish for both fishmeal and}

\section{human consumption part II}

- After discussion on February $12^{\text {th }}$ focus on activities: Phase 1 :

1. Analyses current raw material

2. Production fish oil on laboratory scale

3. Quality assessment of the product

4. Production functional protein and fish oil on laboratory scale

5. Quality assessment of product

6. Production of representative samples

7. Potential added value using lantern fish

\section{Production of fish oil without production}

\section{functional protein}

- State-of-the-art fish oil production: input of fresh fish and output of fish oil and denatured protein meal (fish meal) or fish hydrolysate

- Technology offered by commercial parties. The options for lantern fish will be assessed by

the 3 steps:

- Approaching technology providers

- Production of raw fish oil samples on laboratory scale

- Quality assessment of the product
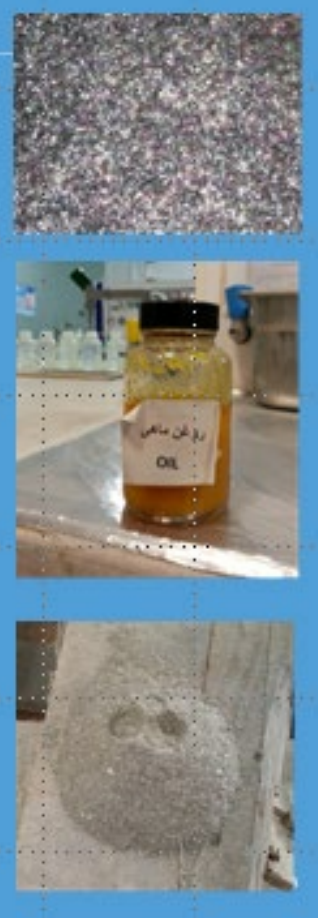


\section{Production of fish oil without functional \\ protein production}

\section{Raw material}
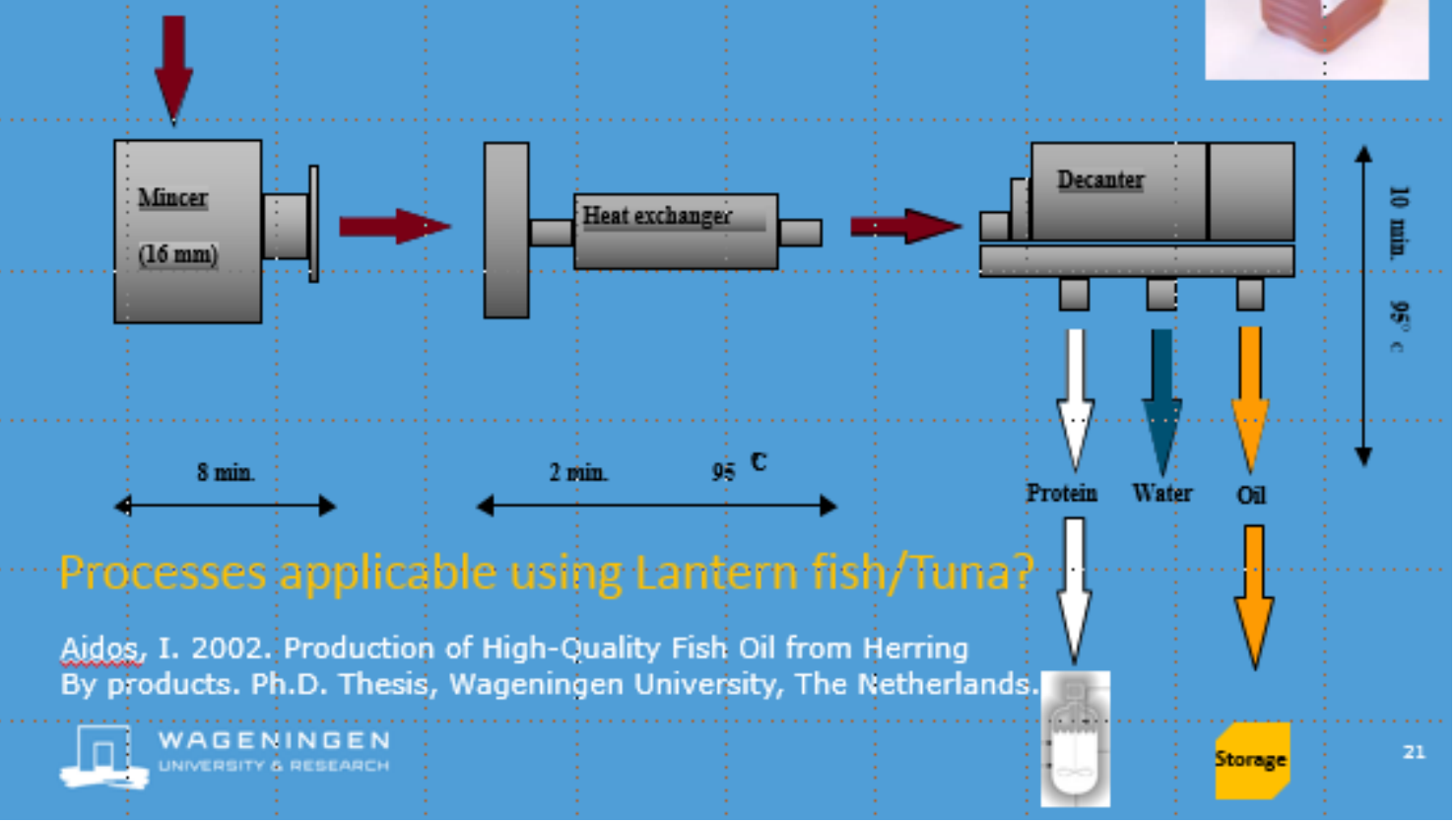

Decanter

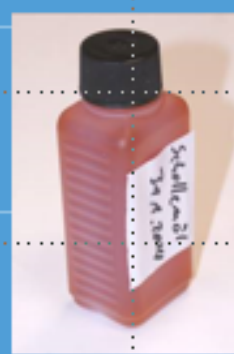

\section{Flow diagram:}

fishmeal

production

\section{line}

\section{Zhoushan Xinzhou Fishmeal} Machinery Co. http://wrww.fishmealplant.com

Flow Diagram of the Fishmeal Production Line

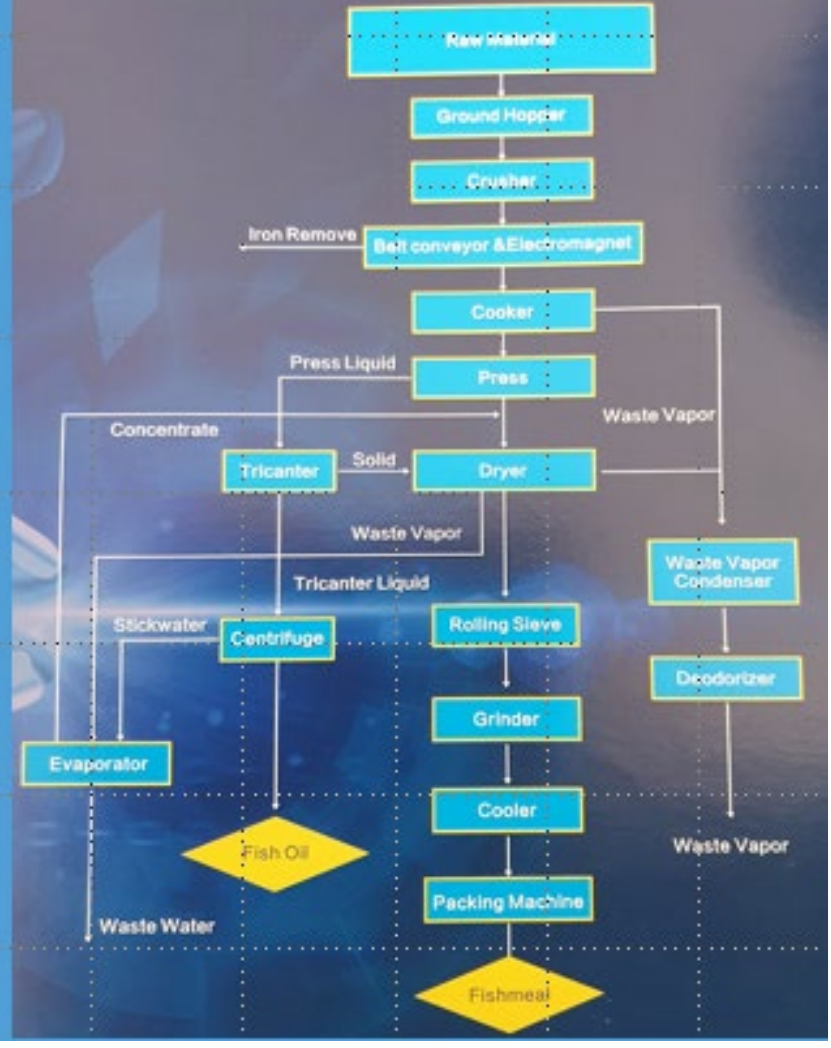




\section{Fishmeal production line}

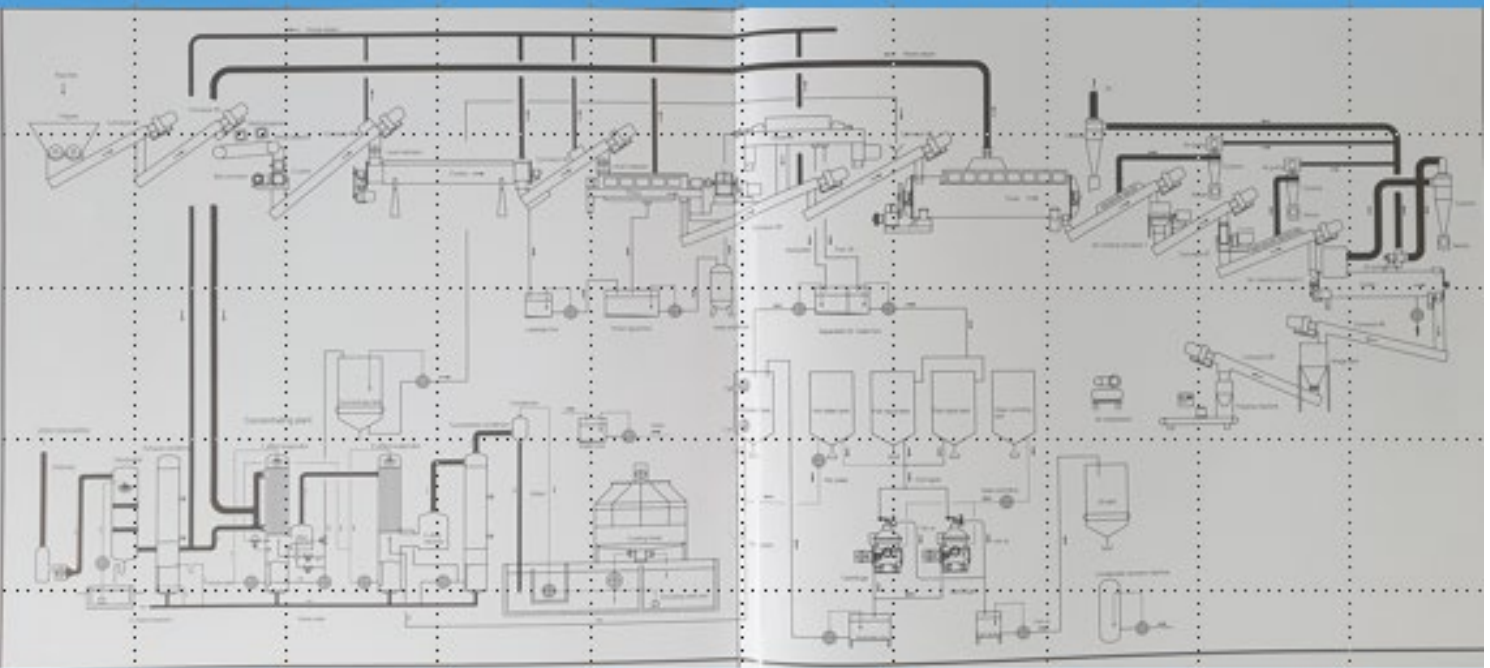

Zhoushan Xinzhou Fishmreal Machinery

\section{Literature: oil from lantern fis|î,}

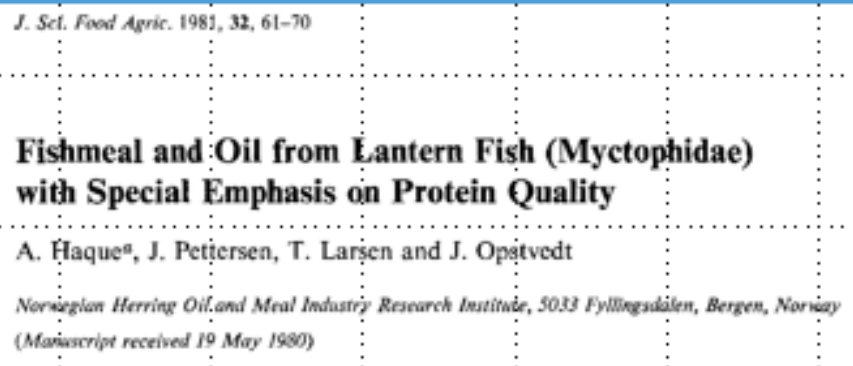

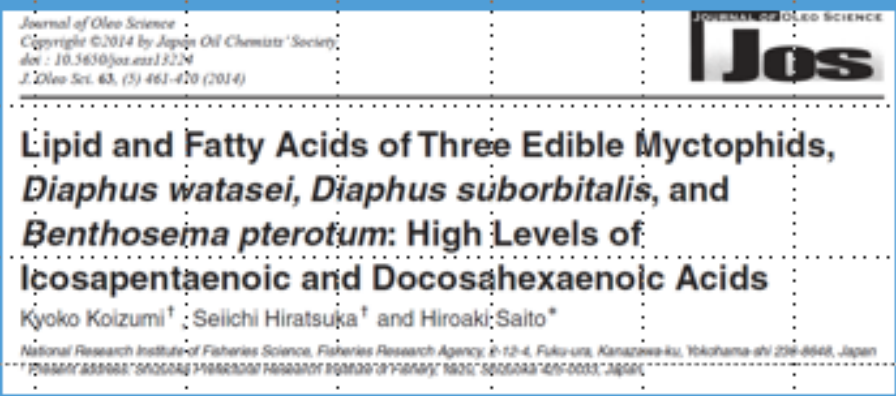




\section{Ex. Comp. protein \& oil from lantern fish}

\begin{tabular}{|c|c|c|}
\hline & LFM: & CrM \\
\hline \multirow{2}{*}{\multicolumn{3}{|c|}{ mainit }} \\
\hline & & \\
\hline 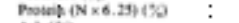 & as (ass.j) & \\
\hline $\cos 19$ & $15.2(16.4)$ & 10.0 \\
\hline Fon CSother (90 & 6.19 .6 & 10.7 \\
\hline Total lipide os : : & & 15.2 \\
\hline 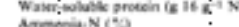 & 13. & 19.2 \\
\hline \multicolumn{3}{|l|}{ Mividil } \\
\hline Calciven 190 & 3.64. & \\
\hline Mectoris is & $\because e^{\circ}$ & \\
\hline Mapienus $1 \%$ & 0.33 & 0.21 \\
\hline sodiugn 68 & 1.10 & 0.95 \\
\hline 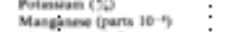 & $\begin{array}{l}0.94 \\
6.1\end{array}$ & $\begin{array}{l}9.88 \\
3.6\end{array}$ \\
\hline Zns fours $10 \rightarrow$ & $\infty .3$ & $\pi, 5$ \\
\hline Const garts 10.6) & 8.5 & 3.2 \\
\hline boe fyaris 10-7 & 50.3 & $\$ .1$ \\
\hline 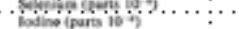 & $3_{4 i}^{3}$ & . \\
\hline Fuertine (quars 10.9 & is & \% \\
\hline \multicolumn{3}{|l|}{ 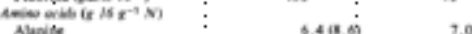 } \\
\hline $\begin{array}{lll}\text { Anvile } \\
\text { Vation }\end{array}$ & $3,40 \%$ & $\begin{array}{ll}7.0 \\
00\end{array}$ \\
\hline Glycisy & 5.40 .27 & 61 \\
\hline Holevicine & 4.619 .8 & $\because 0$ \\
\hline Lewise & 8.1100 .5 & 3.6 \\
\hline matix. & os & 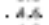 \\
\hline Theoupine & 4.5193 & 4.8 \\
\hline Serise: & 3.814 .77 & 4.9 \\
\hline 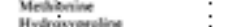 & 3.60 .7 & 3.4 \\
\hline 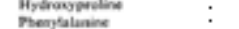 & 9.760 .0 & 0.7 \\
\hline Ateorile nest & 10.714. & $\because 4$ \\
\hline Gistayile axid & 13.609 .9 & 14.1 \\
\hline Tyronines. & 2.30 .4$. & 3.1 \\
\hline Anvinine & $\cos 140.0$ & 30 \\
\hline Trpelephan & $0.9:$ & 1.0 \\
\hline ginin & 1.0 & 1.1 \\
\hline
\end{tabular}

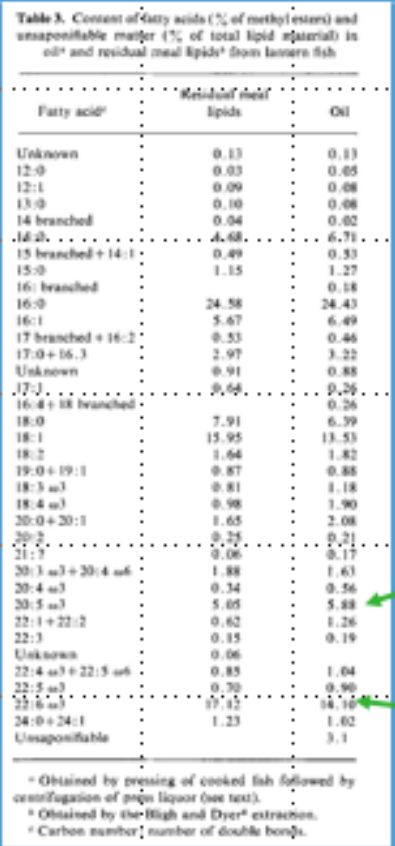

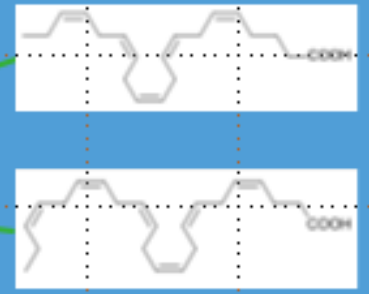

П WAEENINEEN

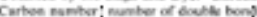

III) UNMERGITY a REEEARCH

\section{Oil recovery and further processing}
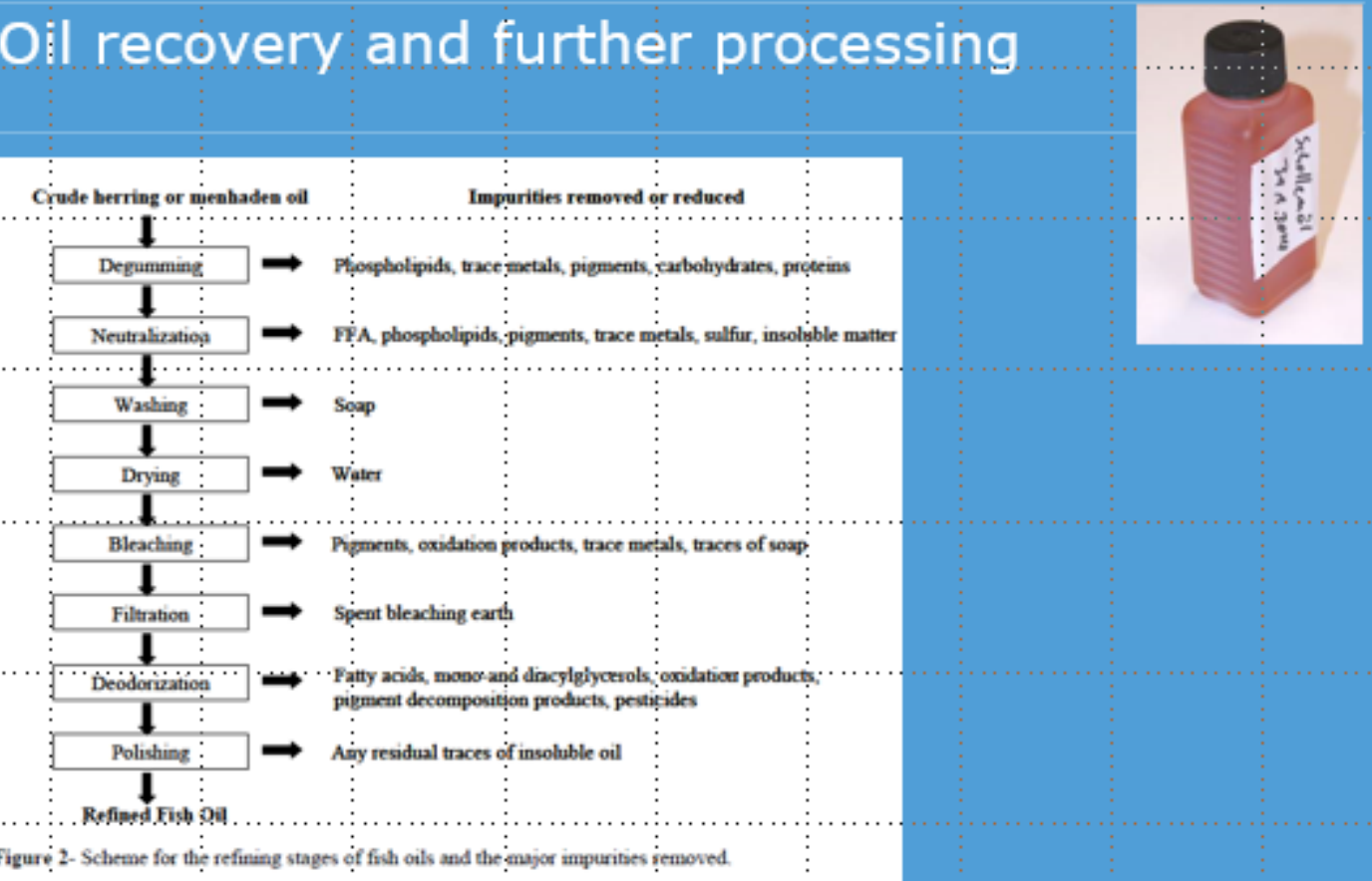

Aidos, I. 2002. Production of High-Quality Fish Oil from Herring By products. Ph.D. Thesis, Wageningen University, The Netherlands. WA GENINGEN 


\section{Production of fish protein hydrolysate}

- Hydrolysis: breakdown of protein into

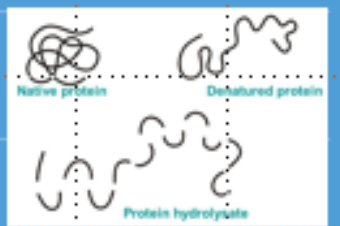
smaller units

peptides and amino acids

- Enzymatic hydrolysis of proteins is a way to modify the properties of proteins
- Solubility
- Viscosity
- Nutritional value
- Increase applicability
- Taste, especially flavor
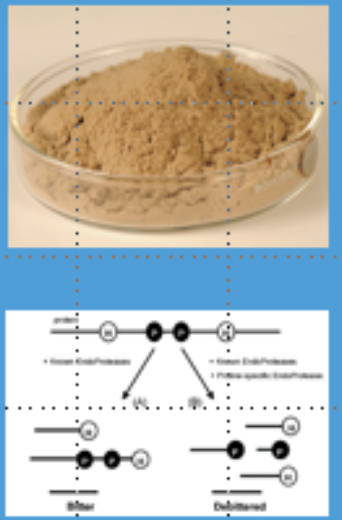

\section{Protein hydrolysis}

- Important process parameters

Type of enzyme

Ratio enzyme - substraze

Temperature

- $\mathrm{pH}$

Duration of hydrolysis

Degree of hydrolysis

- Difficulties

Type of enzyme, endo- or exopeptidase

Taste especially bitterness due to hydrophobic amino-acids (bitter peptides)

Process optimization

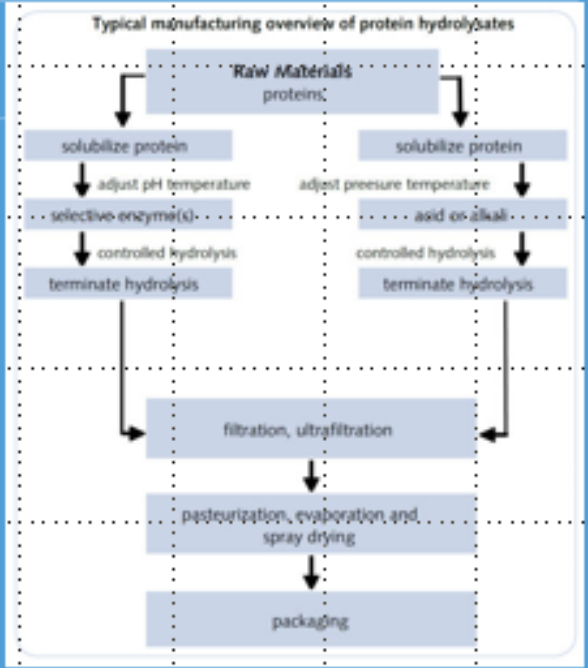




\section{Proteins hydrolysis and bitterness}

1

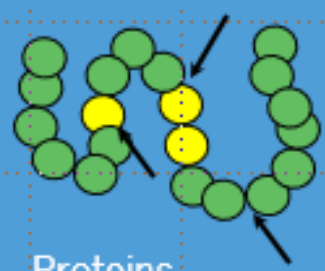

Proteins

2

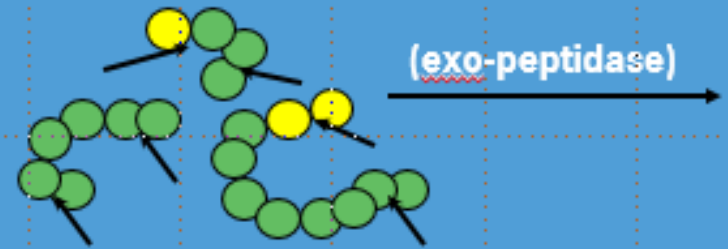

(Bitter) peptides

\section{(endo-protease)}

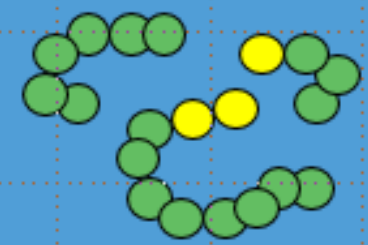

(Bitter) peptides

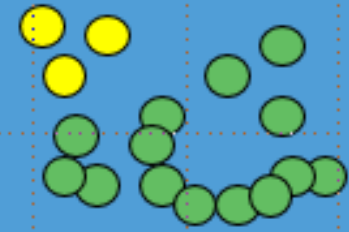

Peptides \& free amino-acids

\section{Example using herring}

- Literature research: Protamex \& Flavourzvme in a two step process

- Concur bitterness

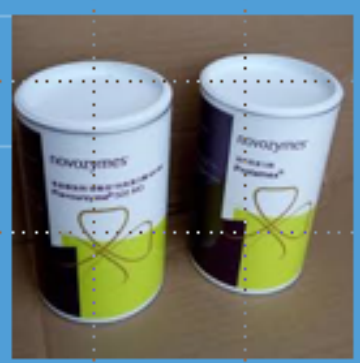

- High DH is possible

- Parameters (table)

\section{Optimum pH Optim $\operatorname{sm} \mathrm{T}$ in ${ }^{\circ} \mathrm{C}$ Max $\% \mathrm{DH}$}

\begin{tabular}{l|l|l|l} 
Protamex & $7-8$ & 50 & $10-20$ \\
\hline Flavourzyme & $5.5-7.5$ & $50-55$ &
\end{tabular}




\section{Example using herring}

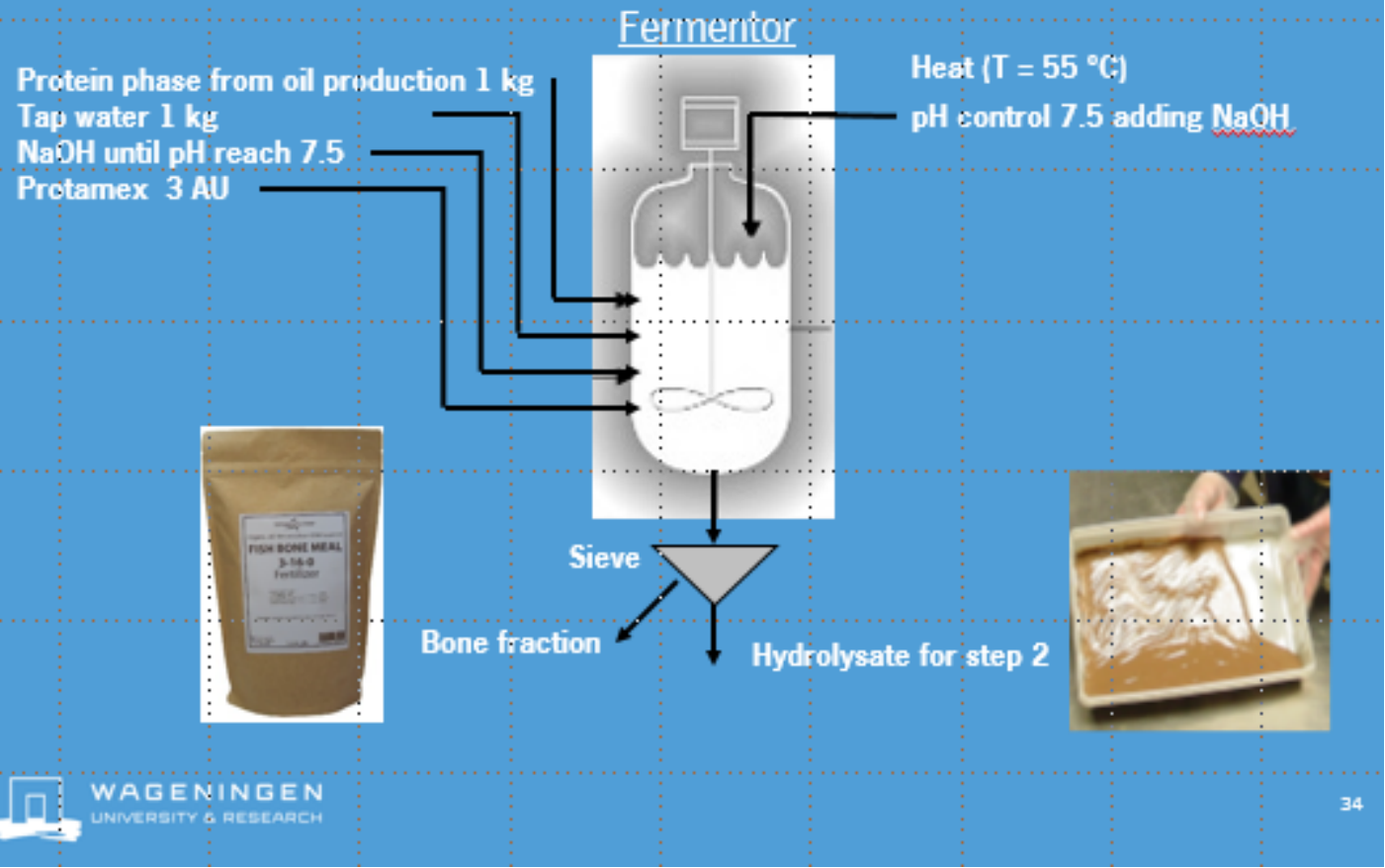

\section{Example using herring}

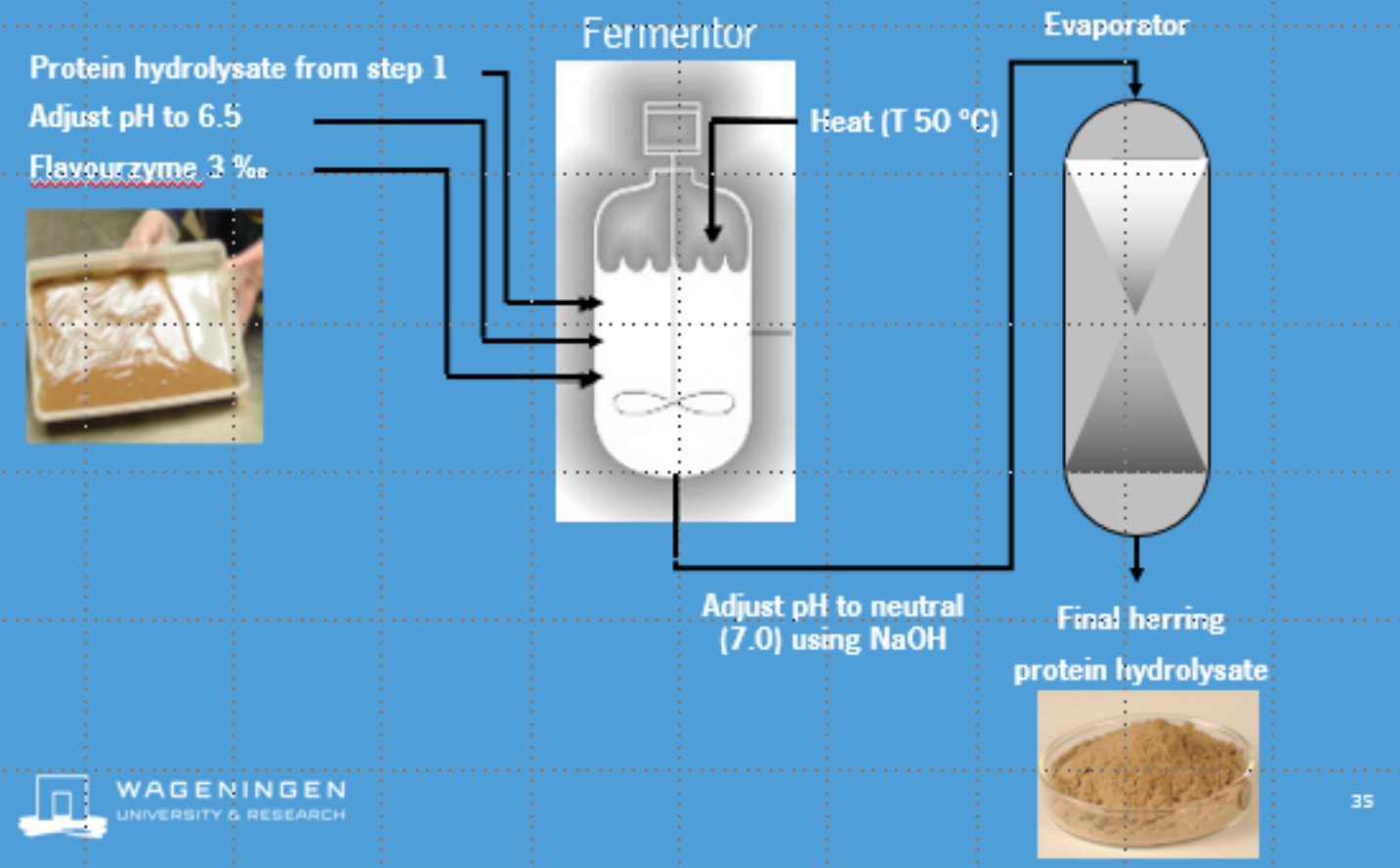




\section{Example of process scheme}

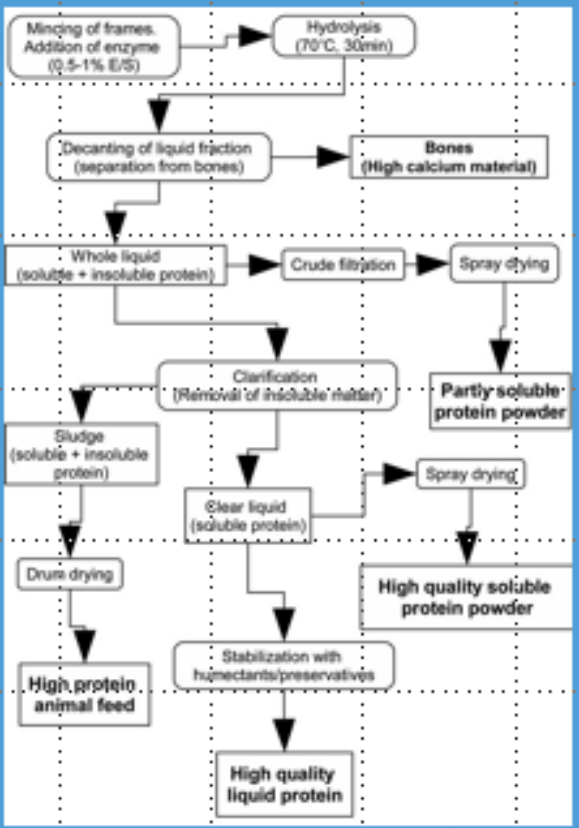

WAEENINEEN

UNIVERSITY a REBEARCH

\section{Bio-active peptides}
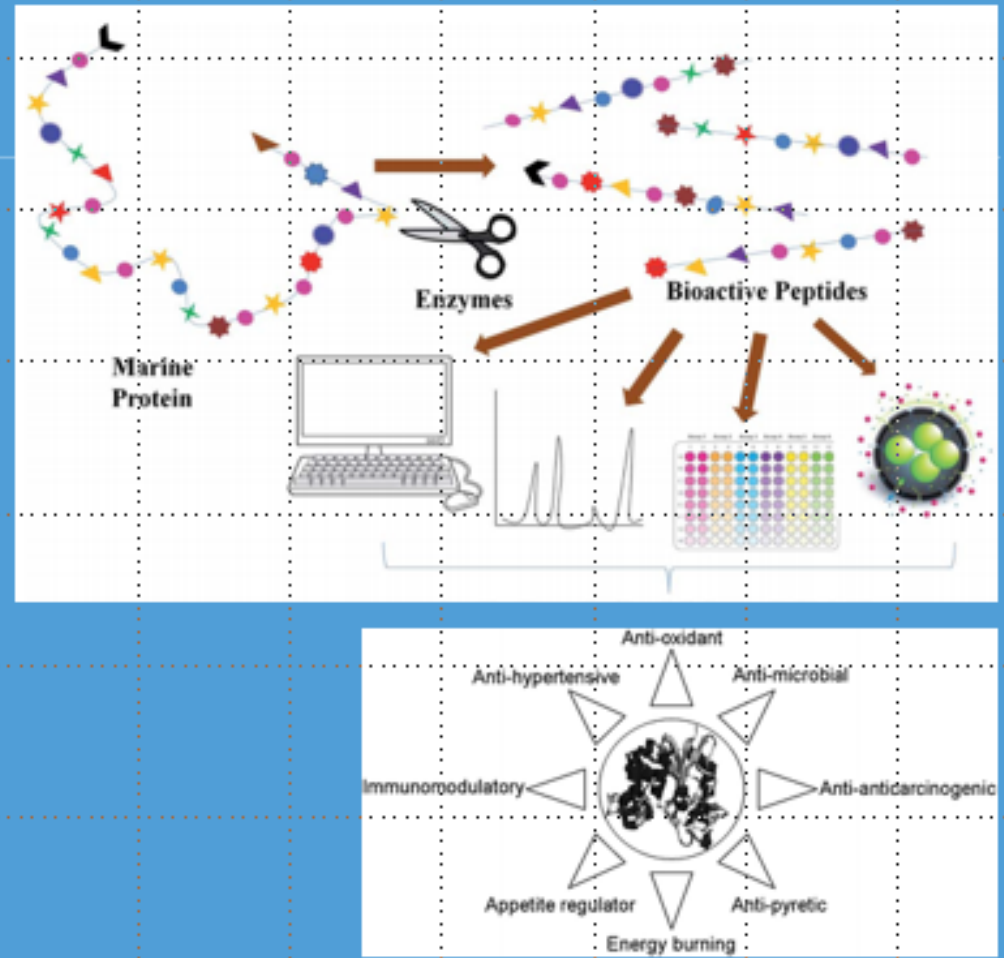


\section{Bio-active peptides, examples from fish}

\begin{tabular}{|c|c|c|c|c|c|c|c|c|c|}
\hline \multirow{3}{*}{ Maister } & \multirow{3}{*}{ 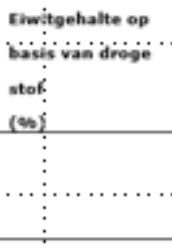 } & \multicolumn{4}{|c|}{ itydrolyse met Aicalase (5 wur) } & \multicolumn{4}{|c|}{ Hydrolyse met Sienlase F (Suur) } \\
\hline & & : & & & & & $\vdots$ & & \\
\hline & & $\begin{array}{l}\text { рн } \\
\text { (थ) }\end{array}$ & 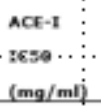 & $\begin{array}{l}\text { DPp-IV-I } \\
\text { IC59 . . } \\
(\mathrm{mg} / \mathrm{ml})\end{array}$ & $\begin{array}{l}\text { DPPH-I } \\
\text { ICзе.... } \\
(\mathrm{mg} / \mathrm{ml})\end{array}$ & $\begin{array}{l}\text { DH (w) } \\
\ldots \ldots \ldots \ldots\end{array}$ & 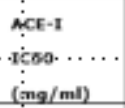 & 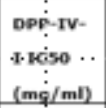 & $\begin{array}{c}\text { DPPH-I } \\
\text {.1630 } \cdots \\
(\mathrm{mgg} / \mathrm{mol})\end{array}$ \\
\hline : : & Heliciscol & $\vdots_{26.2}$ & $0.23:$ & 3.9 & 3.5 & 14.6 & $: 0.12$ & is & $0.5:$ \\
\hline $2 .:$ & schol ingevranden & $\vdots_{63.3}$ & $0.32:$ & 3.0 & 6.3 & 25.6 & $\vdots 0.14$ & i.4 & $0.8:$ \\
\hline 2.: & Sshrillever & $i_{25.3}$ & $0.23:$ & 2.5 & $\times 5$ & 23.0 & $:_{0.23}$ & is. & 1.e: \\
\hline 4. $\vdots$ & $\begin{array}{l}\text { Schill ingewranden } \\
\text { geikdokt }\end{array}$ & $\begin{array}{l}\vdots 0.3 \\
\vdots \\
\end{array}$ & $0.19 \vdots \vdots$ & 4.6 & $>5$ & 21.2 & $\vdots 0.17$ & is & 1.3: \\
\hline 5. : & Tartiot ingemanden & $\vdots 36.7$ & $0.25 ：$ & 2.2 & $>5$ & 29.8 & $\vdots 0.26$ & is & 2.5: \\
\hline 6. $\vdots \vdots$ & Kabibaum inge: & $\vdots 37.4$ & $0.21:$ & 3.0 & 1.2 & 33.8 & $\vdots 0.11$ & 23. & 0.5 \\
\hline : & wanplen & $\because$ & & & & & : & : & \\
\hline 7. $\vdots$ & $\begin{array}{l}\text { zeeduivel inge- } \\
\text { wanilen }\end{array}$ & $\begin{array}{l}\vdots 25.9 \\
\vdots\end{array}$ & $0.11:$ & 4.9 & 1.0 & 22.6 & 0.09 & is & 1.0 \\
\hline 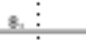 & Schier kesigtast & $\vdots 27.6$ & $0.15 \vdots$ & 3.3 & $>5$ & 16.3 & $\vdots 0.10$ & i. & $0.9 \vdots$ \\
\hline i: & Possikoditinent. & $\because 26,7$ & 6io: & $\ddot{z} \dot{\theta}$ & $\eta_{3} \cdots$ & $\cdots 2 \cos _{2} \cdots$ & 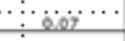 & $\cdots_{i j} \cdots$ & $\cdots_{0,4}:$ \\
\hline$\vdots$ & $\vdots$ & $\vdots$ & $\vdots$ & & & & $\vdots$ & $\vdots$ & \\
\hline sesi & Hudcolonan $F \mathrm{BR}$ & $: 23.3$ & $0.06 \vdots$ & 0.6 & 5.2 & 23.3 & $\vdots 0.06$ & is & 5.2 \\
\hline$\vdots$ & Uringzuur & $\vdots$ & . : & - & 2.3 & - & : & $\therefore$ & 2.3 \\
\hline
\end{tabular}

\section{Bio-active peptides}

- Example of anti hypertensive working bioactive protein

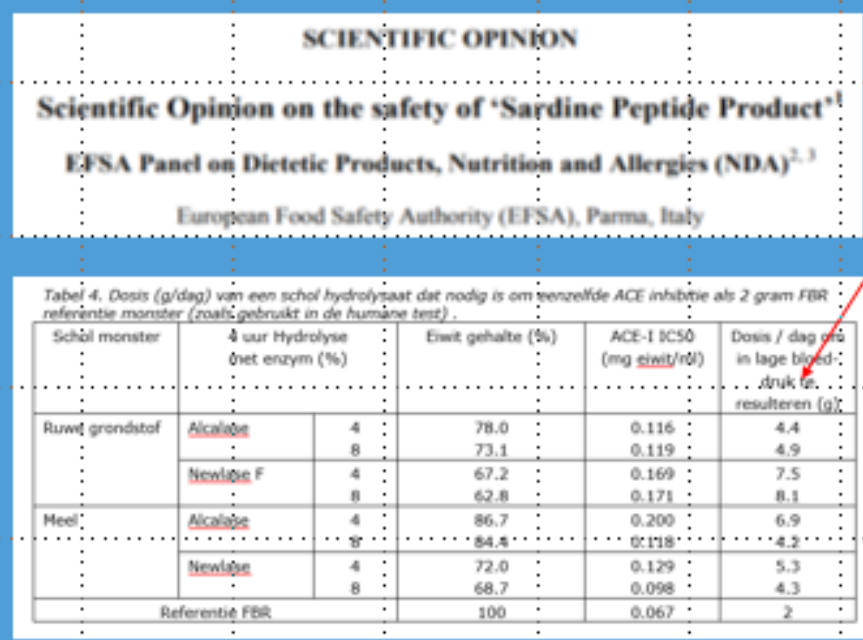
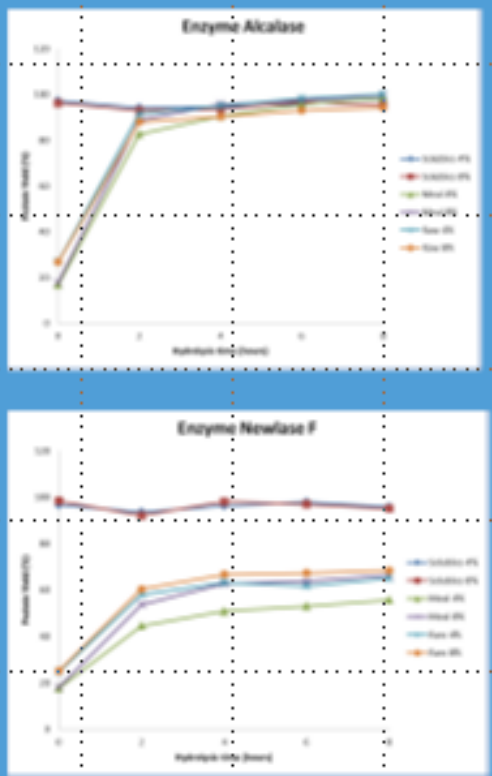


\section{Literature protein hydrolysate from lantern fish}

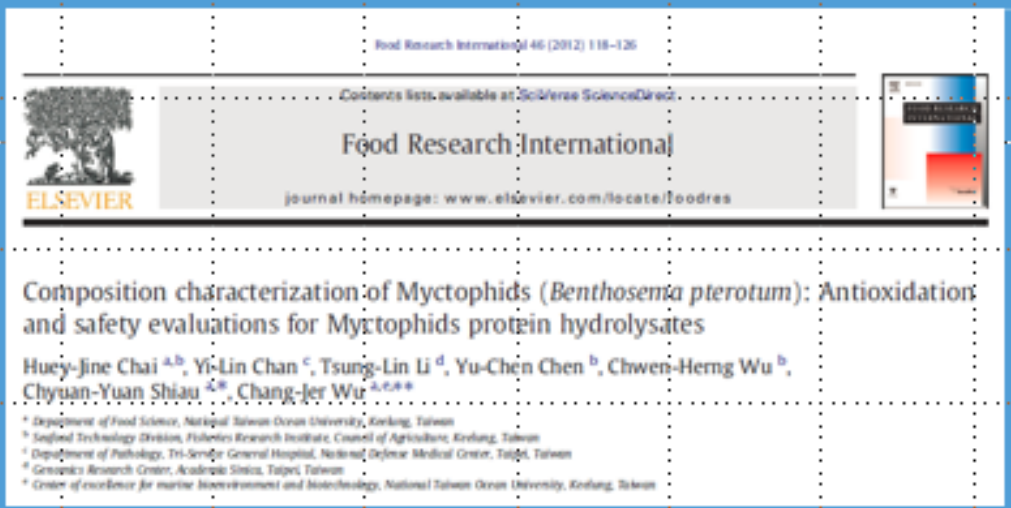

: The jatolytic hydrolysates of BPH were concluded to be safe. Accordingly, BPH is an idejal raw ứaterial for the developments of protein-rich anti:axidative bealthy products.

\section{Production of fish oil and functional protein}

* Production of functional protein requires a technology without a heating step before the protein has been removed from the oil fraction

- WR has demonstrated production of sarcoplasmic (water soluble) and muefibrilliau (salt soluble) proteins from fish and fish by products

- This process can be the base for a technology development for protein production with functional properties from lantern fish 


\section{Increase use of lantern fish for both fishmeal and}

\section{human consumption}

\section{Plàn of action}

- Contacting suppliers of technology

- Production of functional protein and fish oil on laboratory scale

- Assessment of the quality of the products

Increase use of lantern fish for both fishmeal and human consumption

\section{Plàn of action}

- Contacting suppliers of technology

- Production of functional protein and fish oil on laboratory scale

- Assessment of the quality of the products 


\section{Pre-processing, deboning, \\ Processing of minced meat by restructuring fish proteins}

mincing, washing \& dewatering
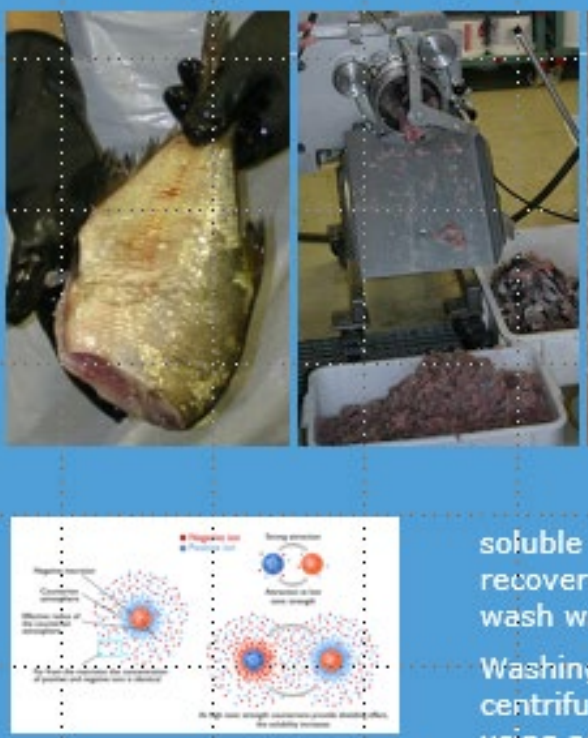

soluble fish proteins recovered frcm wash water

Washing \& centrifugation using acid $(\mathrm{pH}=3.5)$
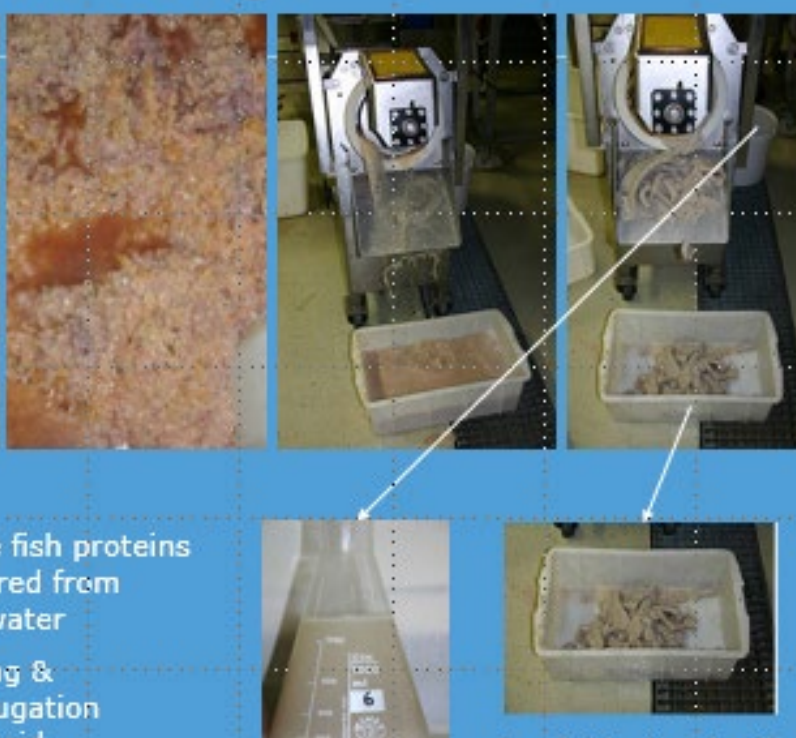

Insoluble (washed) fish proteins recovered from washing

\section{Possible results}

- Processing minced meat and restructuring fish proteins

- Oil enriched "surimi" products using emulsion technology
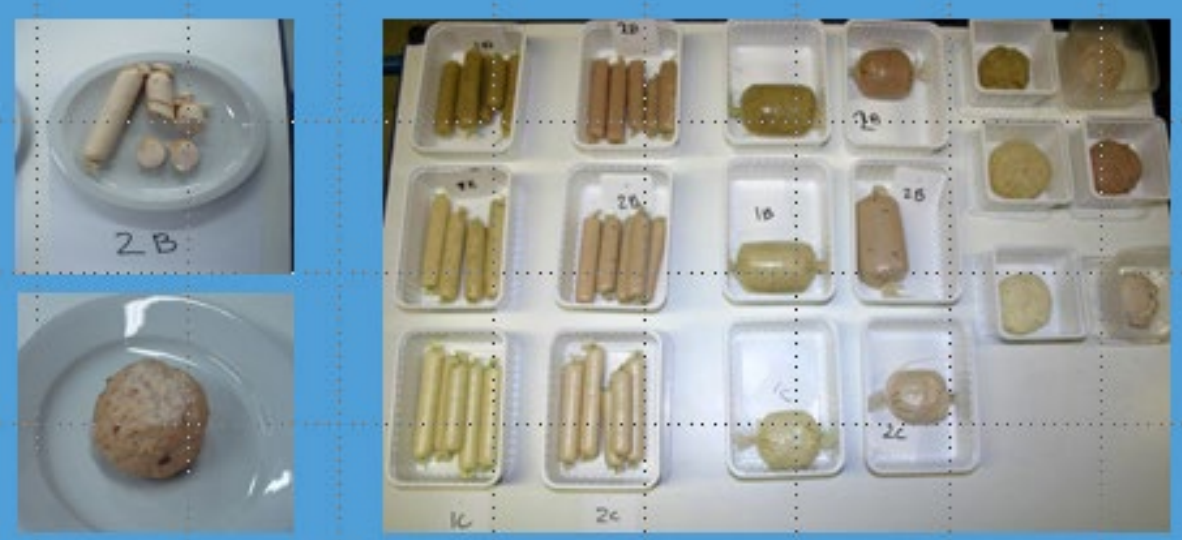


\section{Possible results}

\section{Sliceable cheese products}
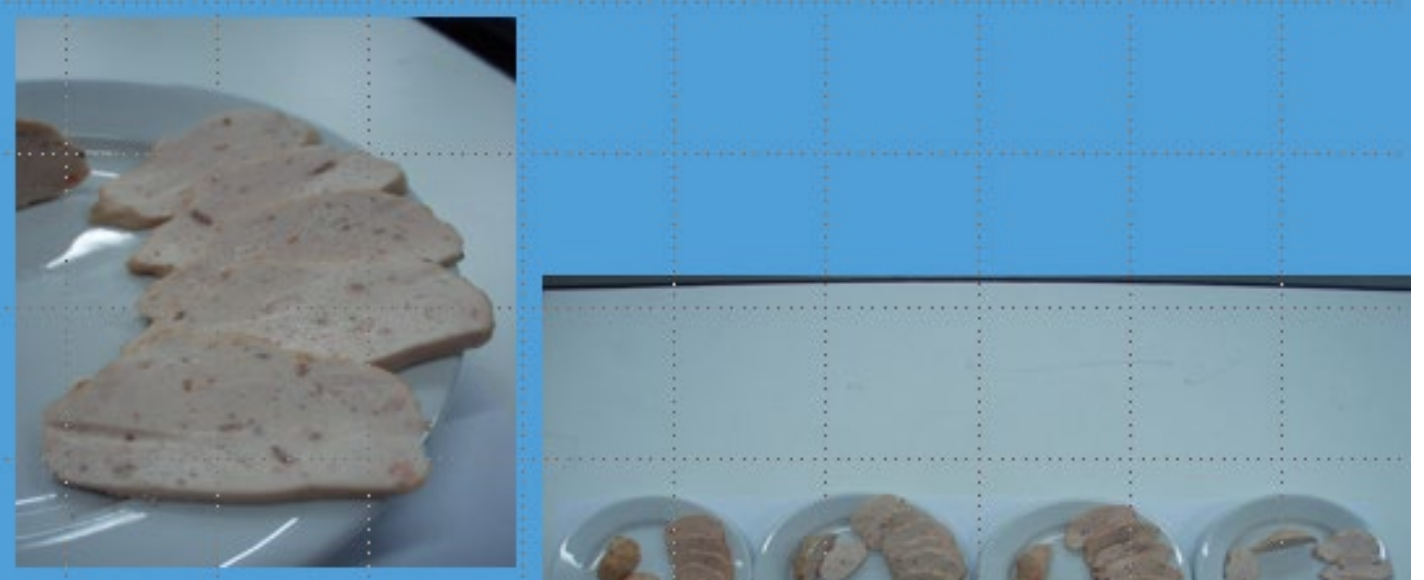

$\sqrt{\square}$ WAGENINEEN

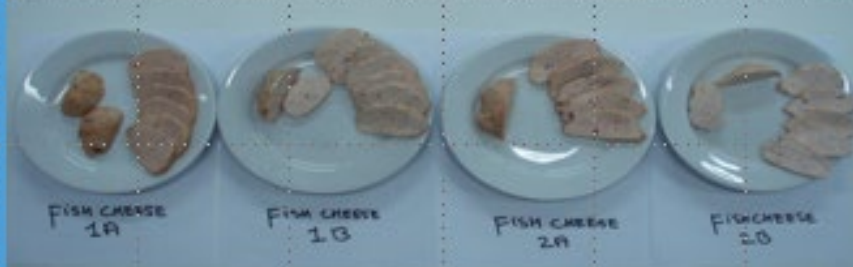

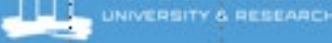

\section{Meat analogues}

- Use of freeze texturizing to produce meat analogues

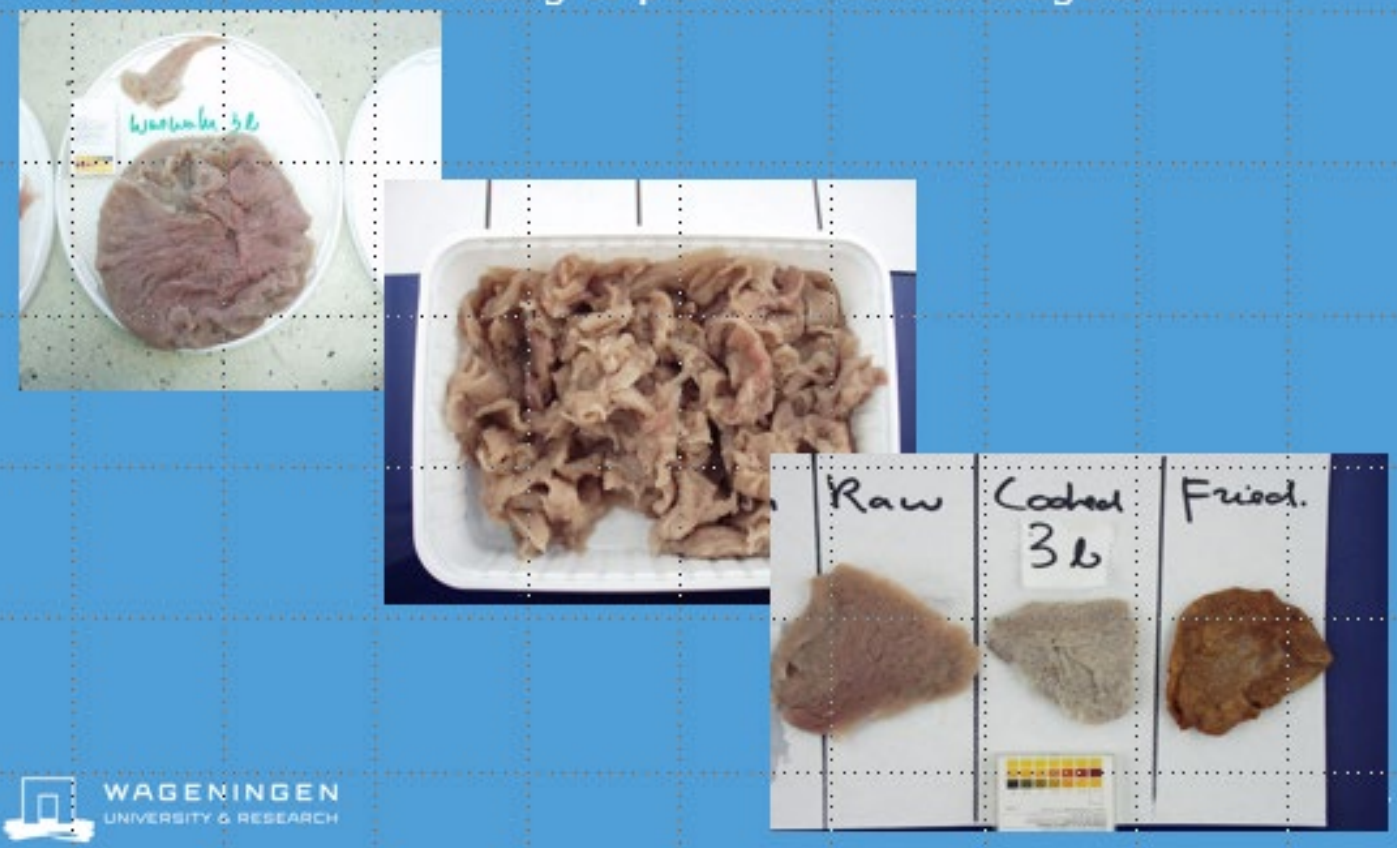




\section{Restructuring by extrusion}

- Creating a structure by mixing, shear and forming through a die opening

- Fish enriched extruded produats to be milled as base for porridge or just as snack
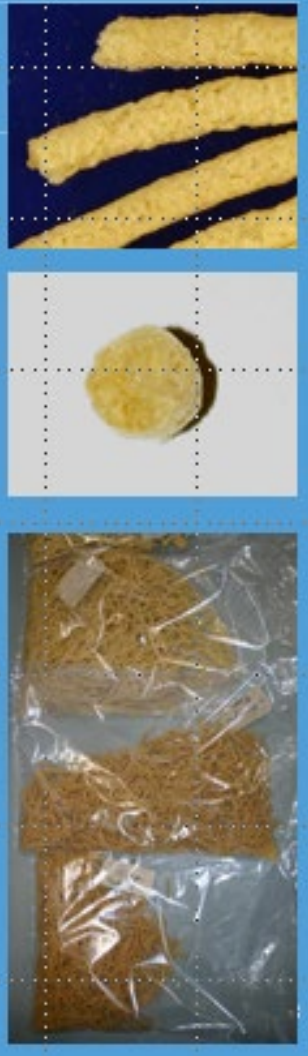

\section{Literature and examples Lantern fish}

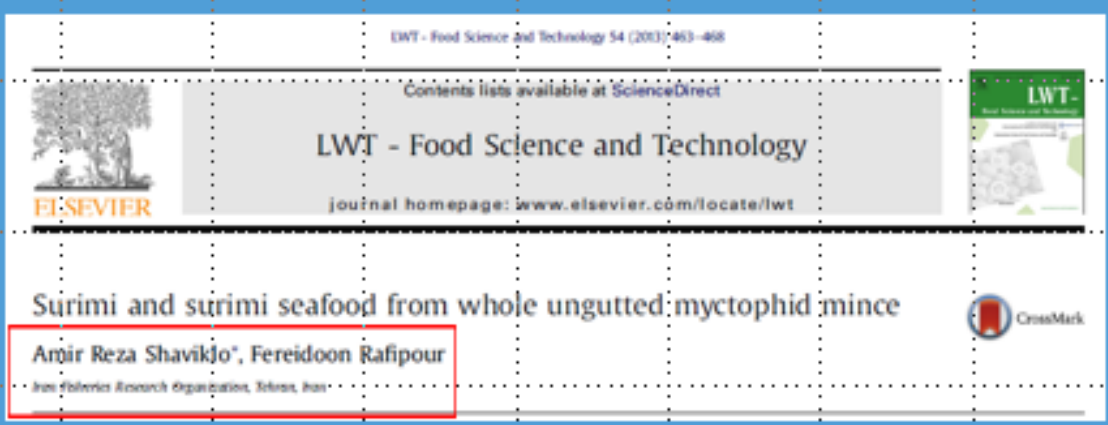

A B S T R i C T

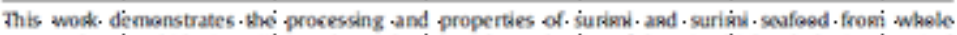
ungutted myetophid mince. The study was based on the evaluation of the microbial and plysicochemical quality and new product development. The microbial counts were reduced effectively during leaching process. Micrubial counts of myctophid surimi were $3 \times 10^{3}$ CFU/g for aerobic plate count, $<10 \mathrm{MpN} / \mathrm{g}$ for total col forms, $<100 \mathrm{CFU} / \mathrm{g}$ fot Staphybcoccus iureus a nd $<10$ CFU/g for ye asts $20 \mathrm{~d}$ molds. The absence of

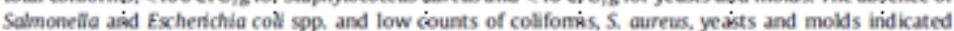

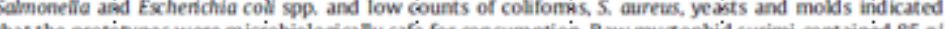

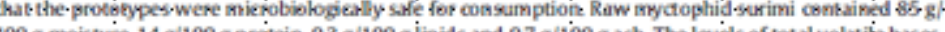
$100 \mathrm{~g}$ moisture, $14 \mathrm{~g} / 100 \mathrm{~g}$ protein, $0.3 \mathrm{~g} / 100 \mathrm{~g}$ lipids and $0.7 \mathrm{~g} / 1.00 \mathrm{~g}$ ash. The levels of total volatile bases. peroode and thiobarbituric jad values of myctophid surimi: were $6.6 \mathrm{mg} \mathrm{N} / 100 \mathrm{~g} .11$ meqjkg and $0.13 \mathrm{mg}$ maldindialdehyde $/ \mathrm{kg}$ iespectively, which were siznificintly lower $(p<0.05)$ than that figund for myctophid mince. Product development indicated that the prototypes had a lower fish odor and flawor and better sonsory scores for.texture attributes than silver carp mince which was a positive point for

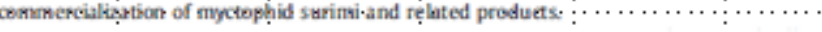




\section{Literature: examples Lantern fish}

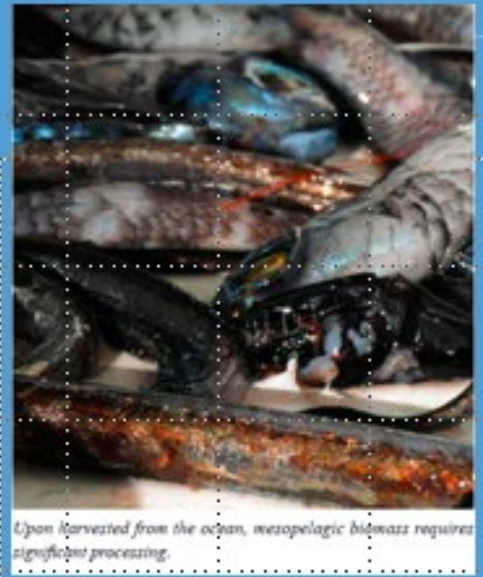

Taken from Mesopelagic Initiative: Unleashing new marine resources for a growing human population

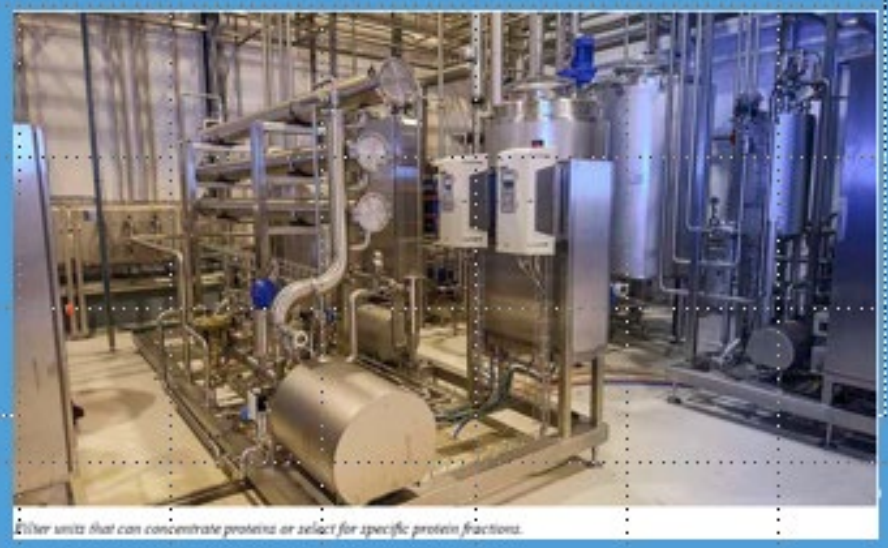

\section{Literature: examples Lantern fish}

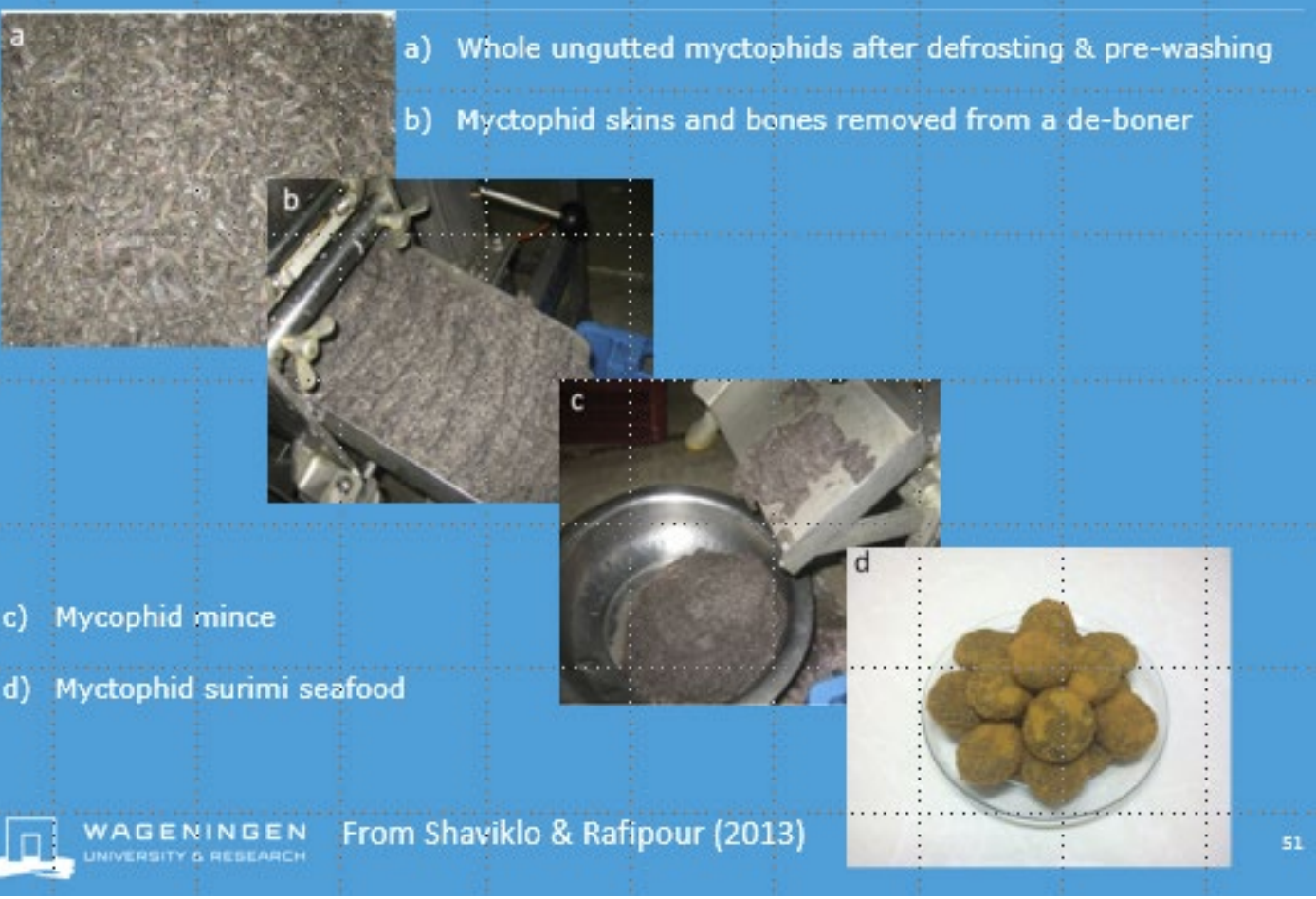




\section{Literature: examples Lantern fish}

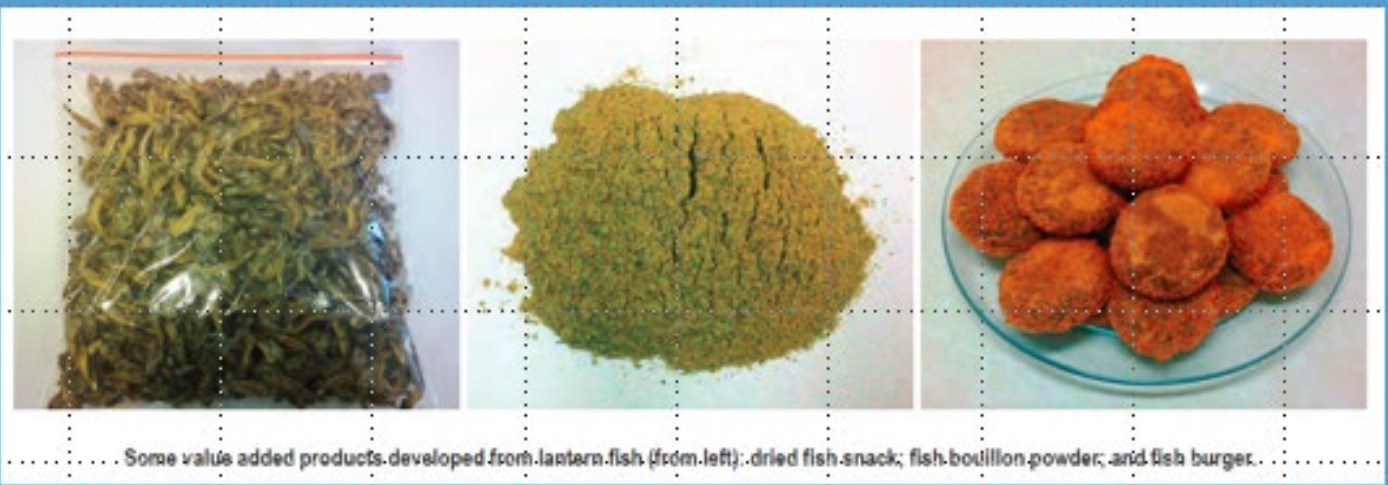

\section{pH shift method}

- Using pH (acid or base) to solubilize an precipitate proteins

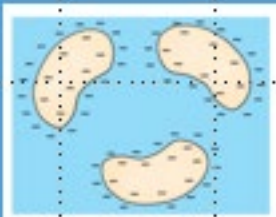

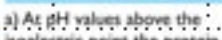
hoelecteric point the
negatively charged

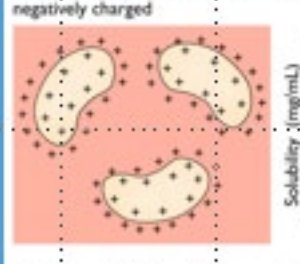

E) At $\dot{p H}$ viloes telow the: aoeledernic point the procein posicivily charged
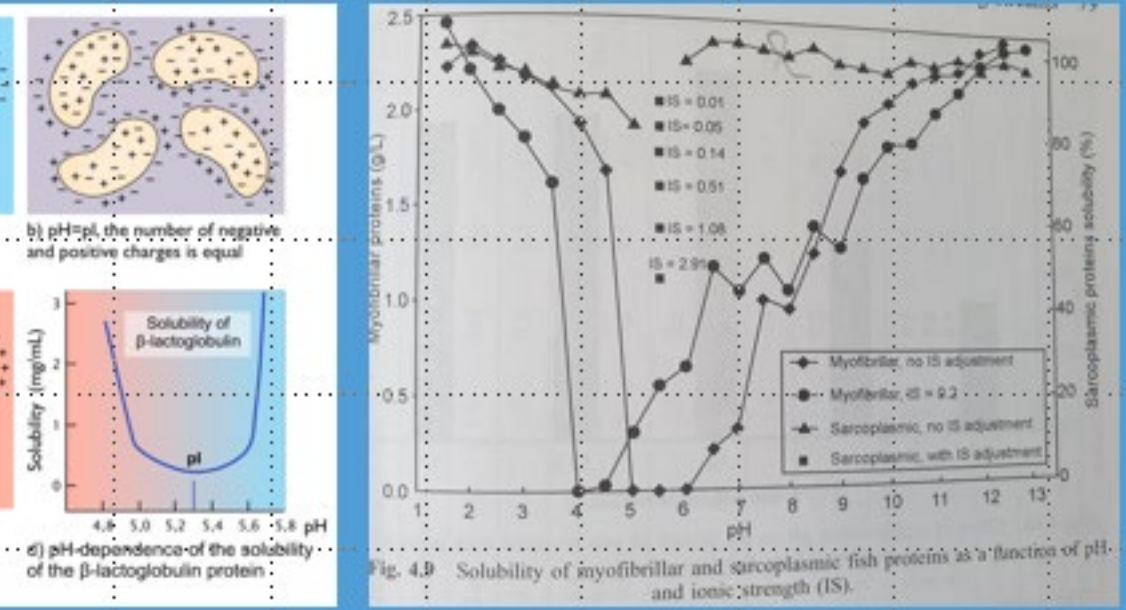

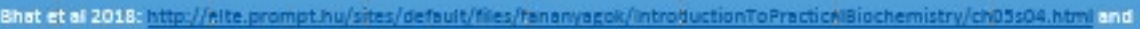
Maximising the value of marine by products esited by Estsidgog Shohide.

D! WAEENINEEN 


\section{pH shift method schematic views}

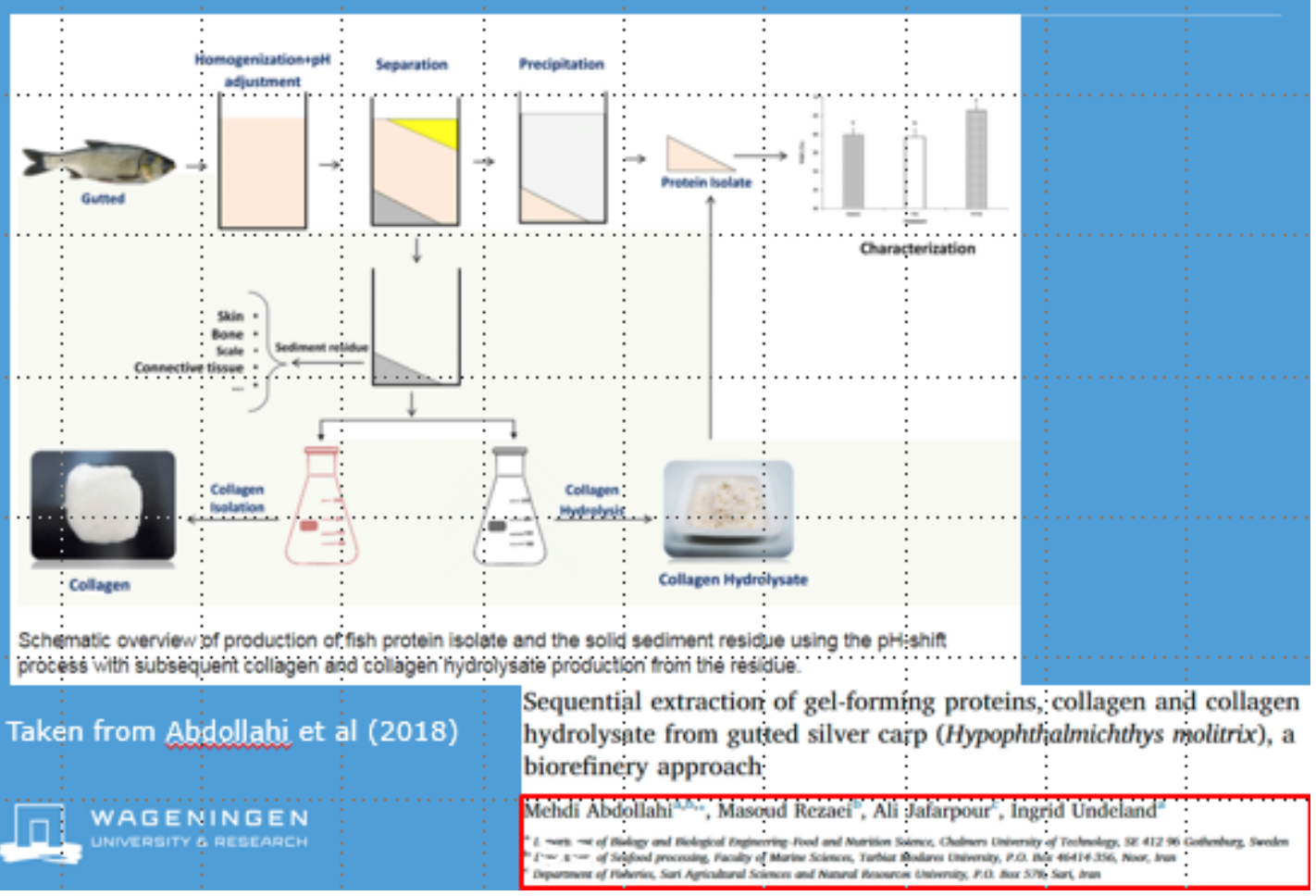

\section{pH shift method}
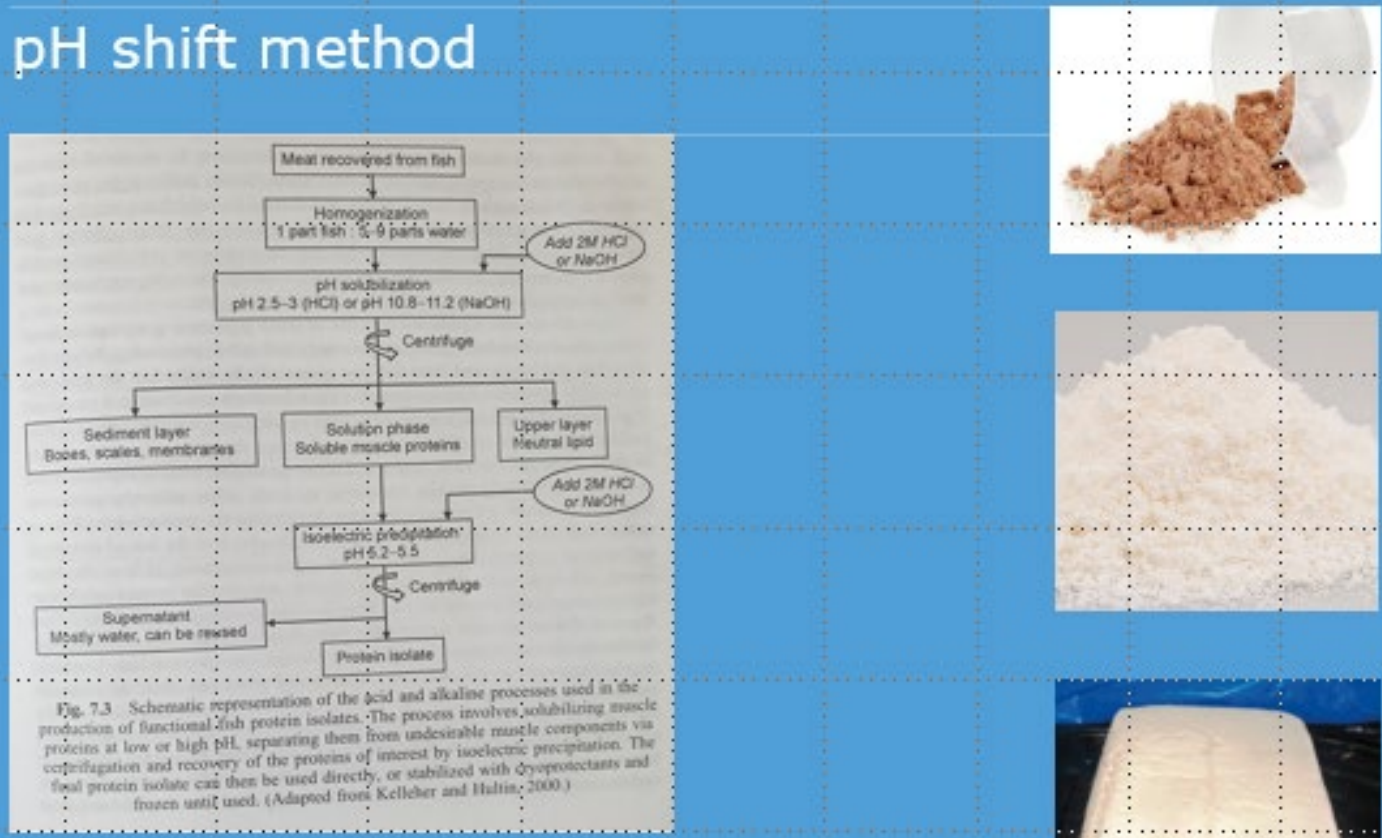

- Demonstration video's of principle: hittps://voutli,be/spovoviBDi4 https://www. youtube.com/watch?v=eqazCt5twsQ

[1] WAEENINGEN

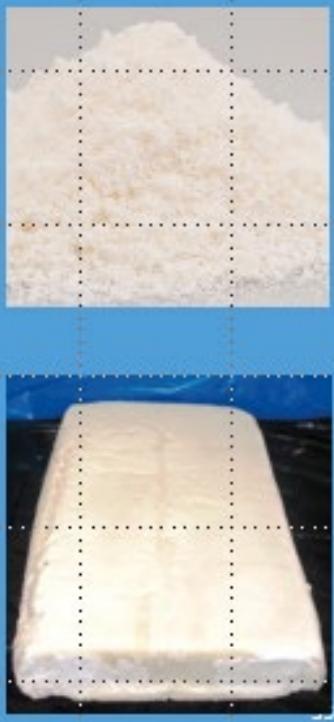




\section{Product examples}

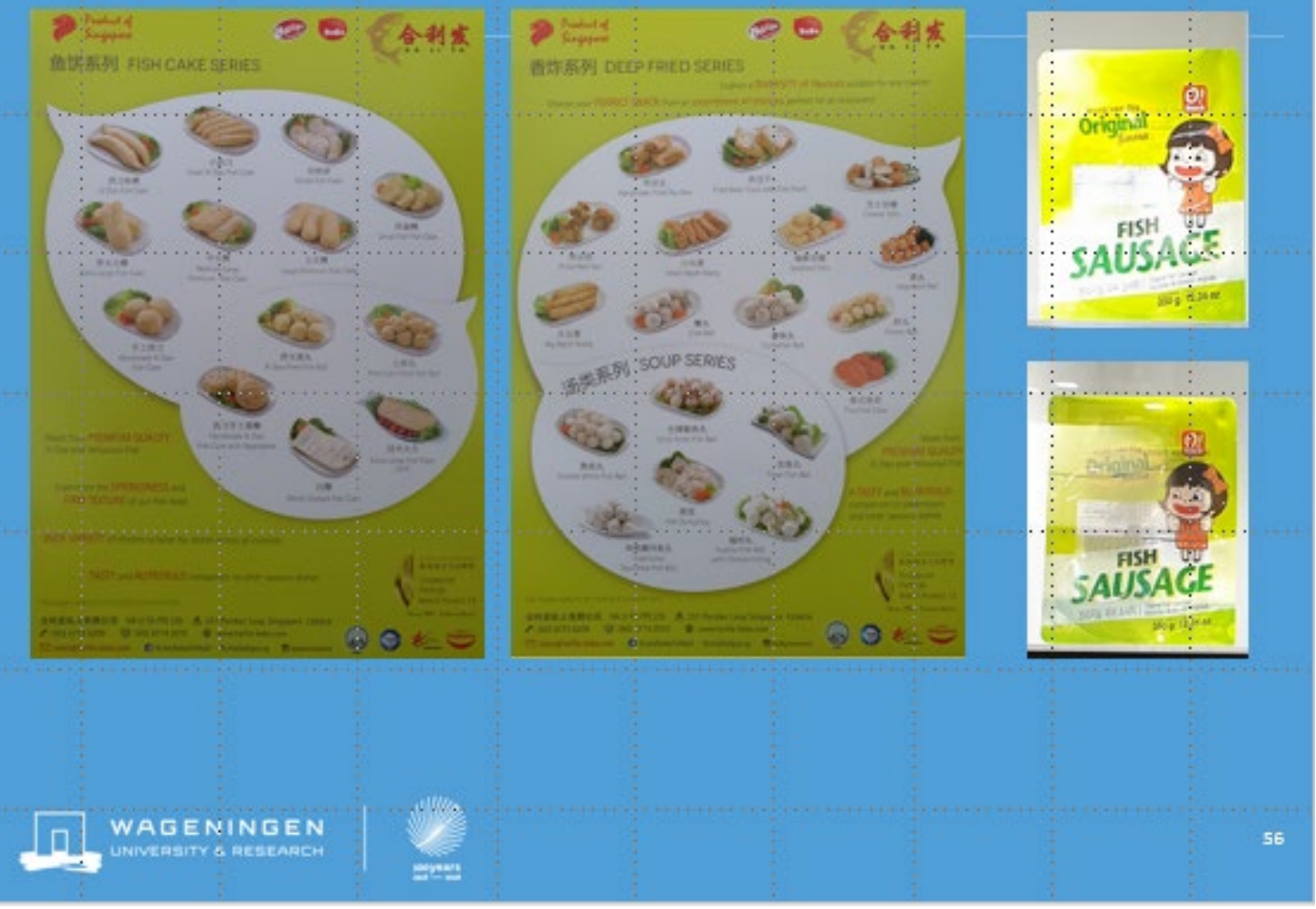

\section{Optional future steps}

1. Potential market study with samples, interest poteritial buyers

2. Discuss results and making plans for follow up with stakeholders and private sector

3. Commercialization of developed products with the private sector

4. WecR is expert institute within WUR
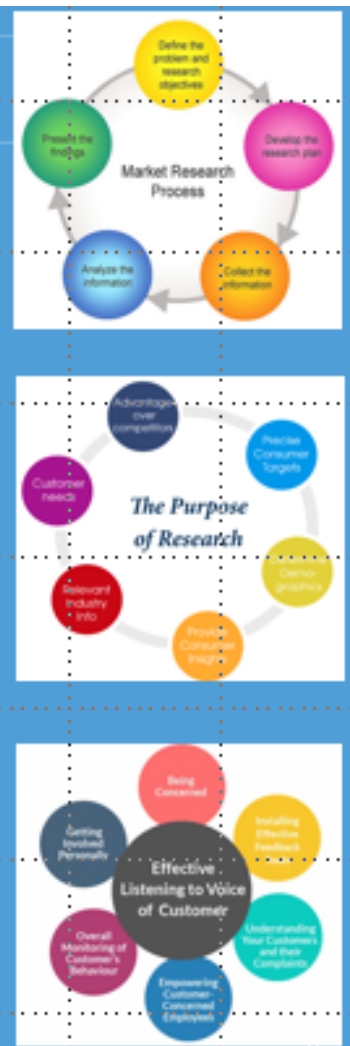


\section{Value pyramide}

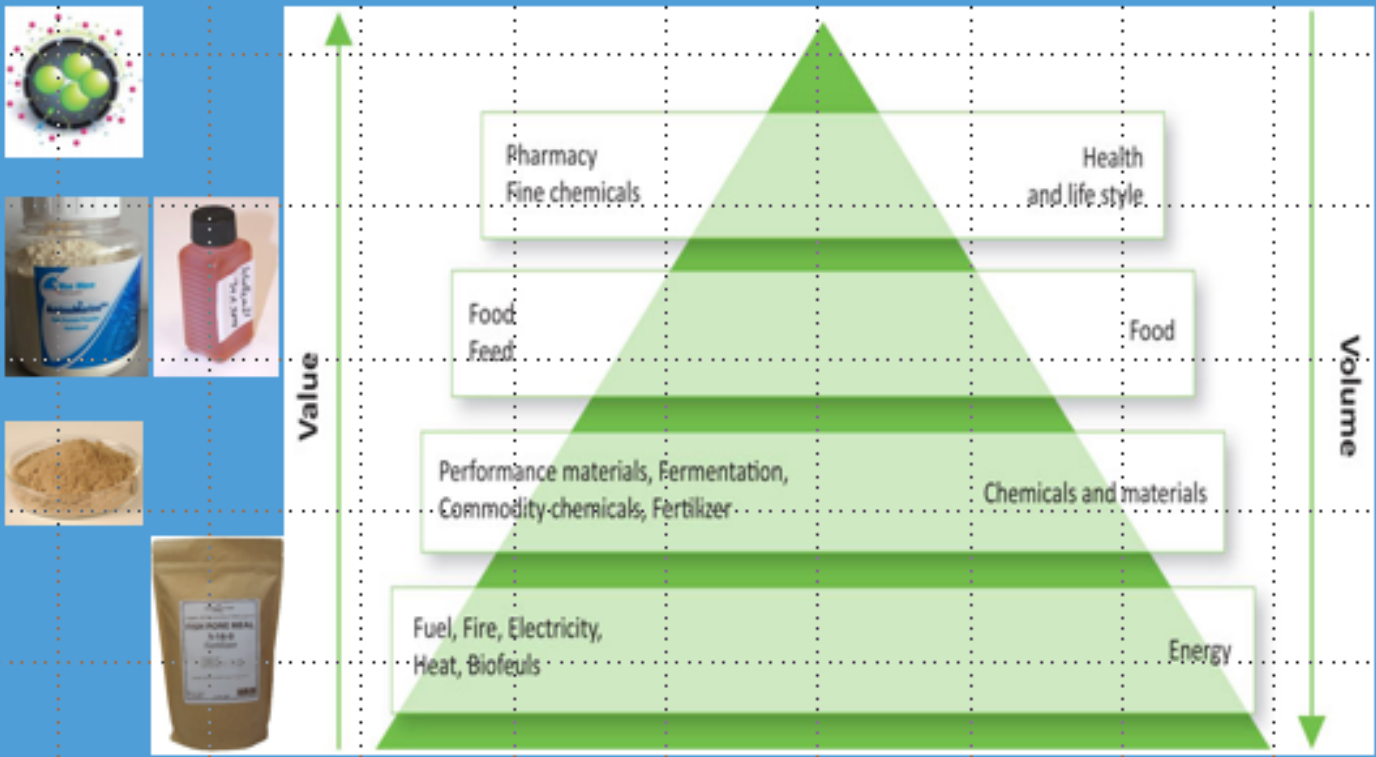

\section{Scenario use of by products/discards/target species}

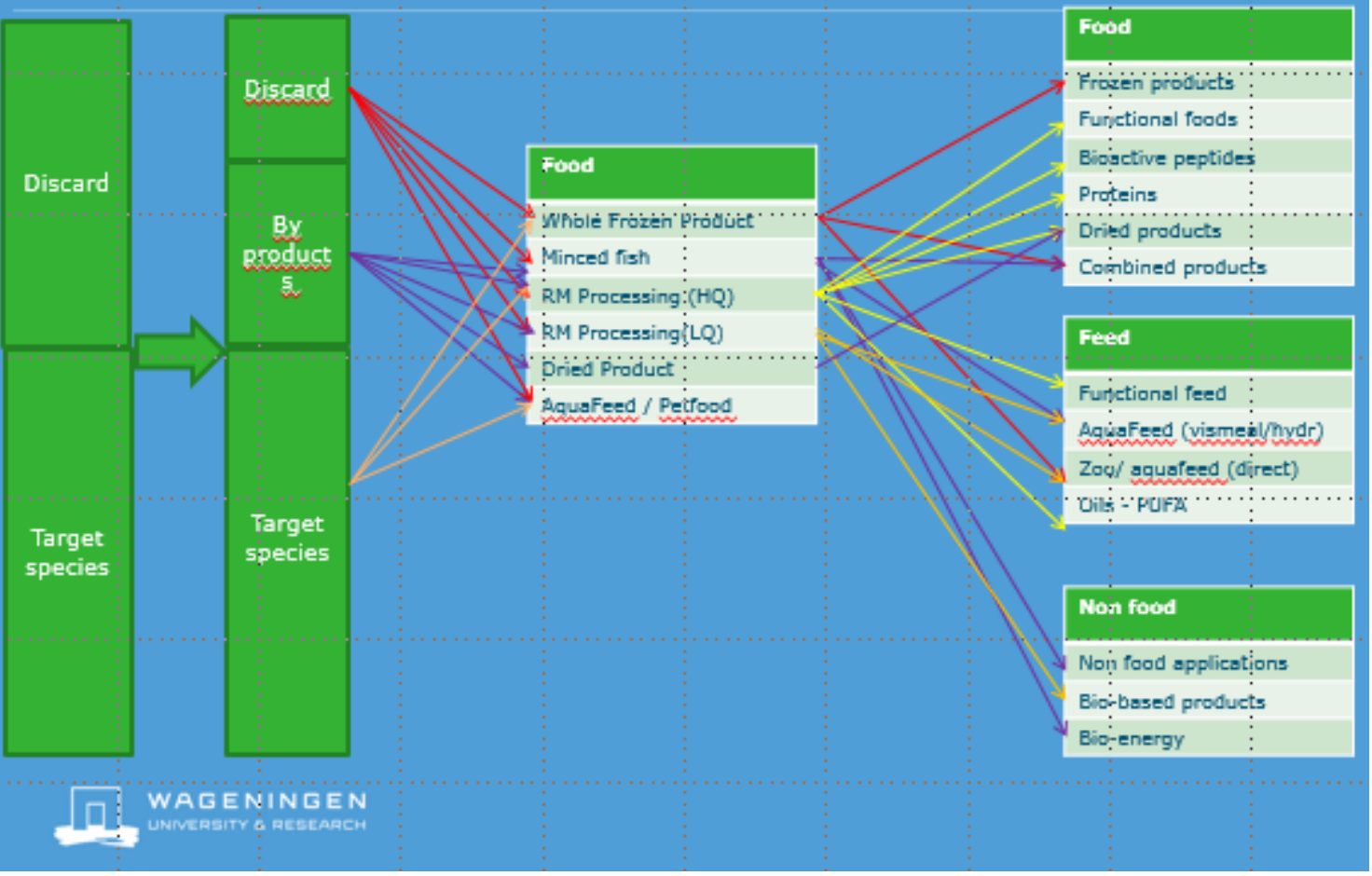




\section{Business case FM \& FO Lantern fish}

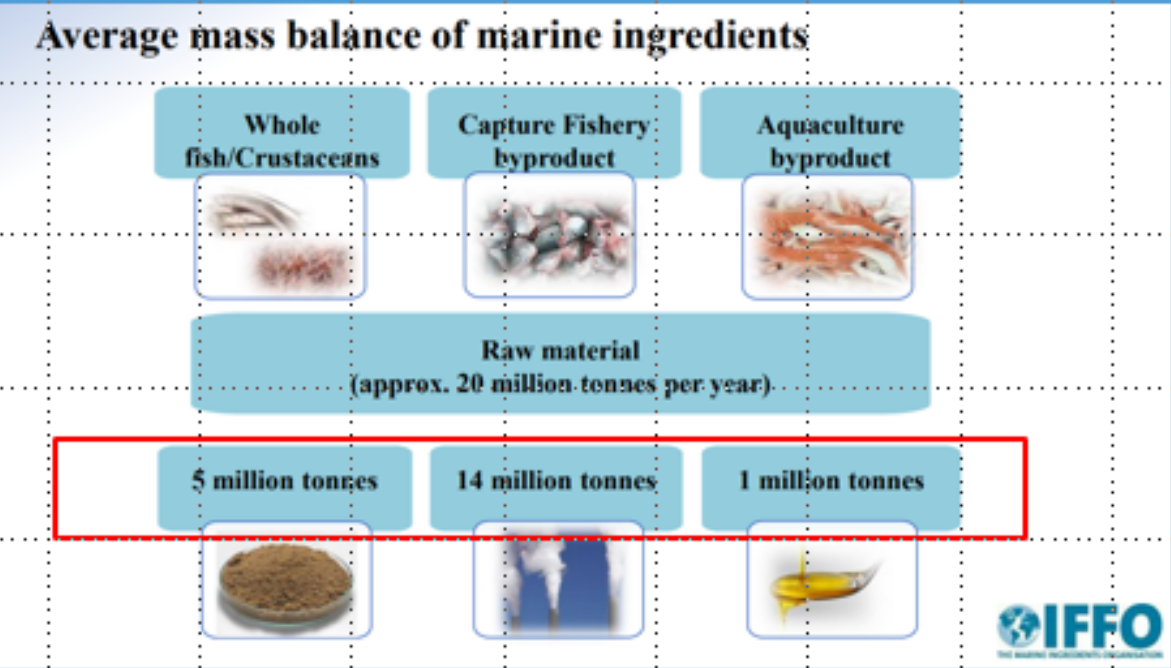

Fishmeal $=>250 \mathrm{~kg}^{-1} \mathrm{n}^{-1}$

Fish oil $=>\quad 50 \mathrm{~kg}$ ton $^{-1}$

\section{Business case FM \& FO Lantern fish}

Goal: increase landings to 100 kton. $y^{-1}$ next 5 years

- $50 \%$ human consumption

$50 \%$ FM and FO

- FM lantern fish $\approx$ SA FM

- Slightly< CP $(65.1 \%)$

- higher ash (13.4\%)

. lower histidine $(14.4 \mathrm{~g} / \mathrm{kg})$

- FO $\approx$ SA FO (El-Mowafi et al, 2010)

- 50 kton $\mathrm{y}^{-1}=>2500$ ton $\mathrm{FO}$

$$
=>12500 \text { ton FM }
$$

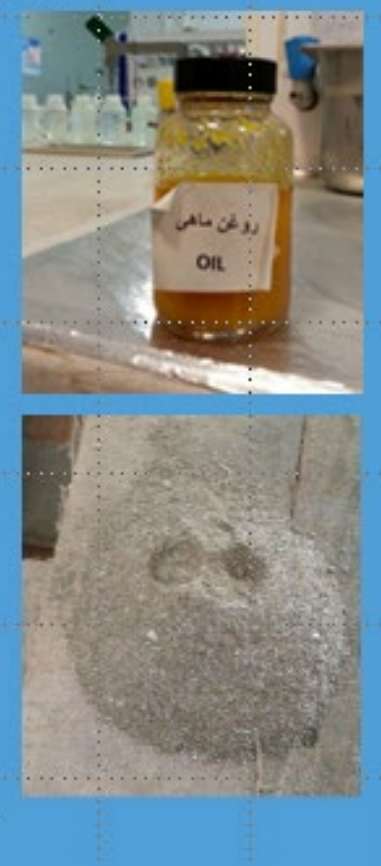




\section{Fish meal and fish oil market}

- Spot market prices FM currently $\pm 1,500$ USD/ton

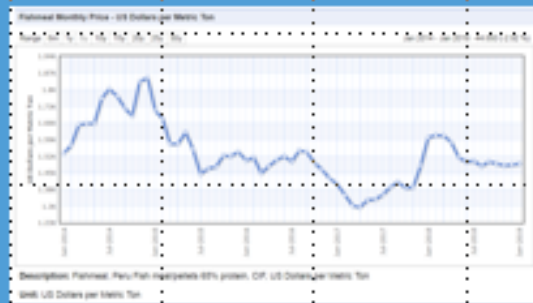

2500 ton $F O \approx 5$ mil USD

- 12500 ton $F M \approx 18.7$ mil USD

- FO prices $\pm 2,000$ USD/ton

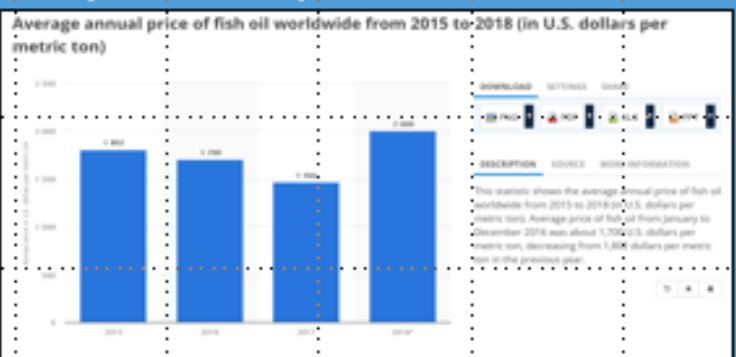

WAEENINEEN

Inttps://wwwindexmundicom/commodities/Zcorimodityefigh-meslämonths=60

nttps://www demalensar.n//wg content/uplosds/2017/11/hier.pdf: 62

intps://www.stotisto.com/staticica/762335/fiah-oli-price-worldwide/

\section{Potential for aquaculture}

- 50 kton $\mathrm{y}^{-1}$

- 2500 ton FO + 12500 ton fish meal $\approx 200.000$ ton tilapia feed

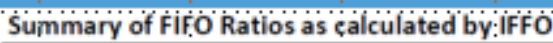

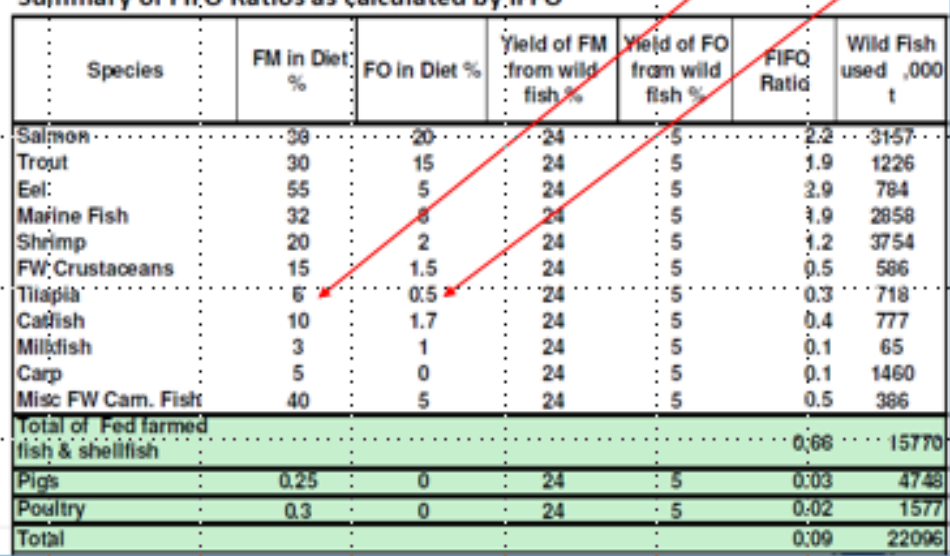

\section{WAEENINEEN}

UNMEREITY RERERTEH
Do not forget the

potential for the

80 kion of tuna

by pioducts 


\section{Book to advise}
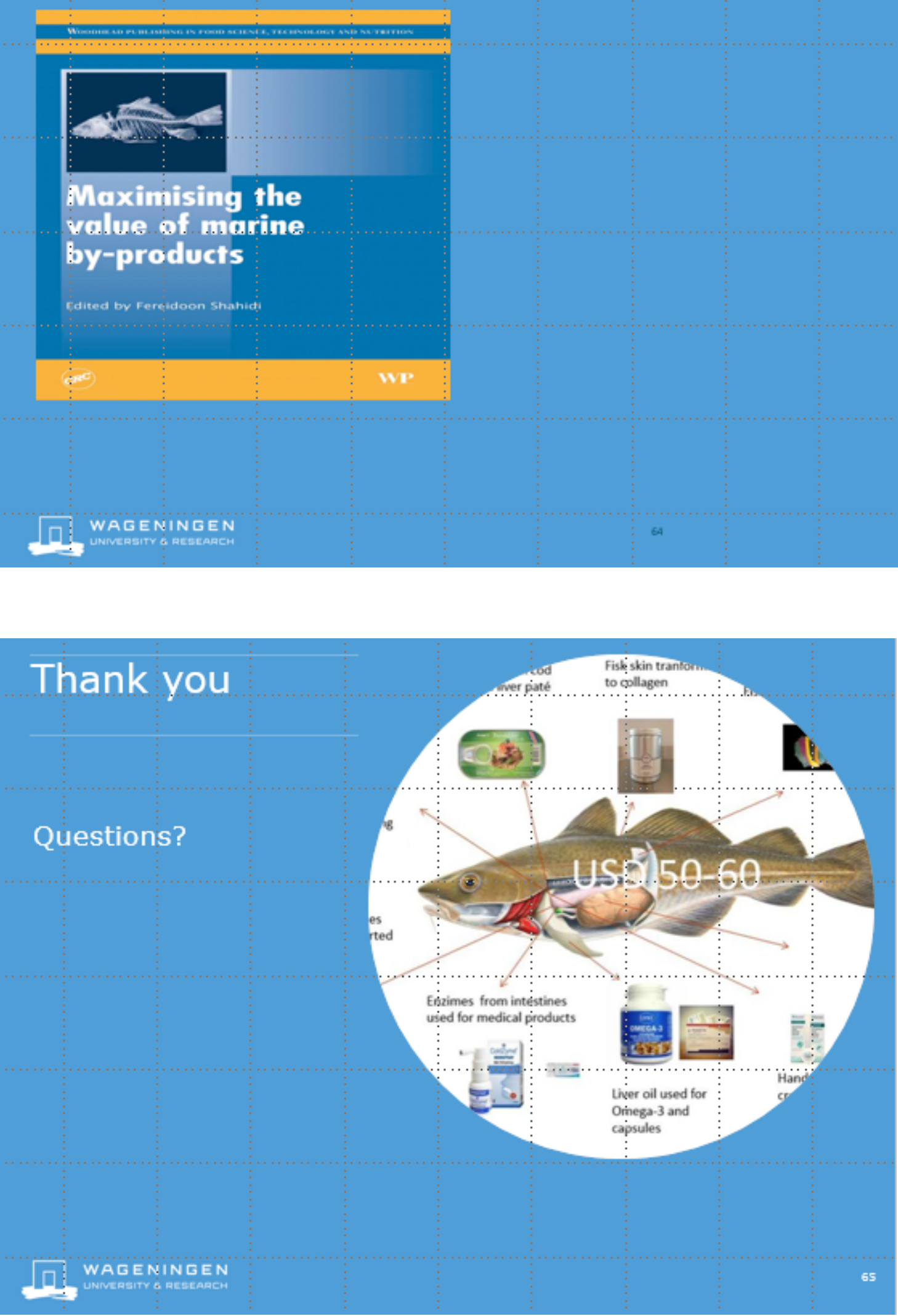


\section{Discussion: keywords, priorities, etc}

- Resources

- Pelagic species

- Lantern fish

- Logistics (cold chain)

- Quality

- Human consumption

- Fishmeal

• Fish oil

- Land animals vs fish

- Economies of scale
- Protein

- Hydrolysates

- Bioactive peptides

- Added value

- Consumer preference

- Supply and demand

- Push and pull

- Aquaculture

- Private sector

- Sustainability 
Appendix 3: Work plans (1 and 2) improvement of the fish value chain in Iran: value creation in fish and fish products 


\section{Work plan 1:}

\section{Project proposal/plan Wageningen Livestock Research}

Improvement of the fish value chain in Iran: value creation in fish and fish products

Jeroen Kals 


\subsection{Introduction and problem definition}

During the fact finding and goal establishing mission of 23rd to the 29th of September 2017, prof Komen and Dr Kals from Wageningen university, together with Mr Smolders of the Dutch embassy in Tehran, and Mr Lomans of the Ministry of Agriculture, Nature and Food quality in the Netherlands visited IFSRO research institutes in Anzali and Ahwaz, fish processing companies in the Persian gulf, and two institutes of the Iranian Fisheries Organisation or Shilat (IFO). Based on discussions with the Iranian deputy minister and colleagues from IFSRO, for fish processing, four objectives were identified as joint research and cooperation priorities.

1. To increase the human consumption of the small pelagic species like anchovy, kilka and sardines currently used for fishmeal.

2. To increase the resource use efficiency of tuna by products.

3. The increase of the use of lantern fish for both fishmeal and human consumption and

4. The development of products using carp as a raw material.

For each of the four goals a brief introduction, and suggested plan of action was described in the report "Improvement of the fish value chain in Iran: introduction of modern breeding technology, product innovation and value creation in fish and fish products".

For processing, The Islamic Republic of Iran has recently given priority to research objective 1: to increase the human consumption of the small pelagic species like anchovy, kilka and sardines currently used for fishmeal and

3: the increase of the use of lantern fish for both fishmeal, fish oil and human consumption and asked Wageningen University and Research to write a project proposal for the two priority objectives.

\subsection{Objectives}

\section{Objective 1: Increase the human consumption of the small pelagic species}

\section{Introduction and problem definition}

In Iran currently most of the 100.000 ton of the small pelagic species caught (e.g. anchovy, sardine, kilka, figure 1) are used for the production of fishmeal. For example from kilka only $10 \%$ of the catch is used for human consumption, the rest is processed into fish meal. However, as the small pelagic species have a high nutritional value, also for humans (e.g. proteins and essential fatty acids), it is more efficient to use them for direct human consumption as you gain approximately a factor four by going down in trophic level. In addition, the Iranian government wants to stimulate the fish consumption in Iran as the average yearly consumption per capita is $11 \mathrm{~kg}$, which is almost half the global average.

During the fact finding and goal establishing mission a plan was made in consultation with our Iranian colleagues to increase the human consumption of the small pelagic species from the Gulf of Oman in the south (anchovy and sardines) and the Caspian Sea in the north (kilka).
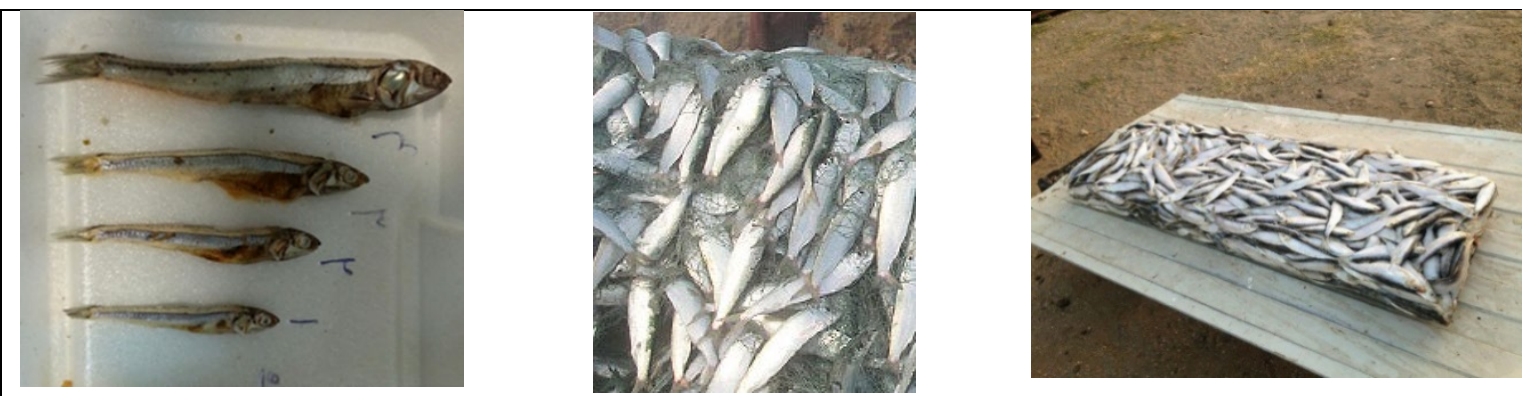

Figure 1: Anchovies (left), sardines (middle) and kilka (right). 


\section{Objective 2: Increase of the use of lantern fish for both fishmeal and human consumption}

\section{Introduction and problem definition}

According to the data presented the maximum sustainable yield (MSY) of lantern fish is much higher than the current catch, which is about 15 kton a year. The goal of the Iranian government is to increase lantern fish landings to 100 kton in the next five years. Currently, lantern fish is only used for the production of fishmeal. However, the goal of the Iranian government is to allocate or use $50 \%$ of the landings for human consumption.

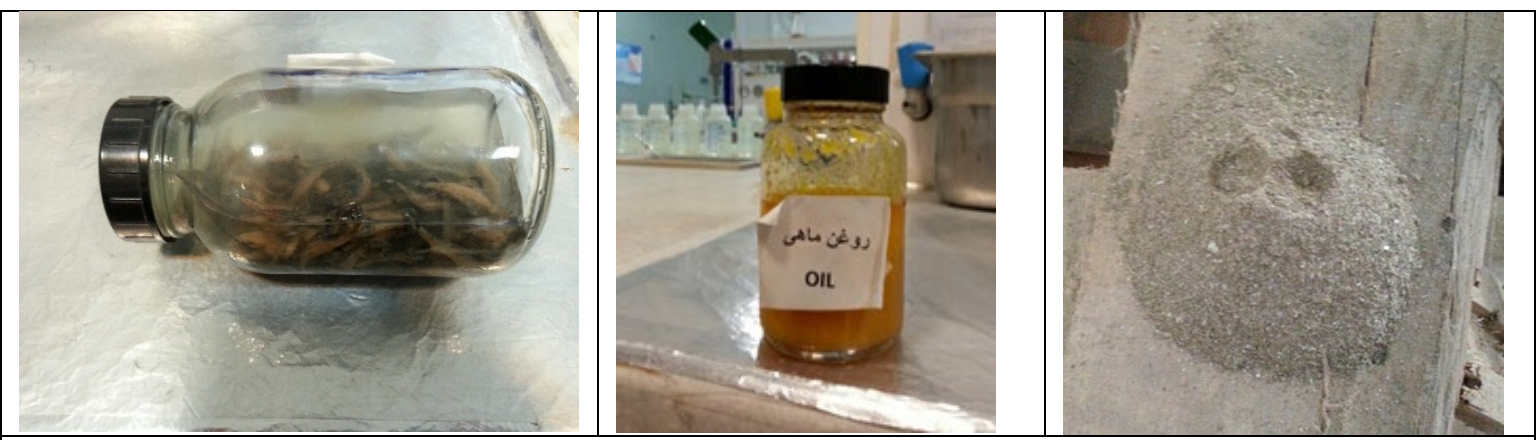

Figure 2: Lantern fish (left), fish oil (middle) and fish meal (right) from lantern fish.

\subsection{Results}

The Wageningen partners (WLR, WFBR and WECR) will jointly prepare a report in English describing the materials and methods, results and conclusions of the project.

\subsection{Boundaries, conditions and restrictions}

\section{Availability of raw materials}

All necessary raw materials (fish) not available in the Netherlands and needed for the project (e.g. sufficient amounts of lantern fish) will be provided by IFSRI (Iranian Fisheries Sciences Research Institute) and AREOO (Agricultural Research Education and Extension). It is the responsibility of IFSRI and AREOO to make them available for research in the Netherlands.

\subsection{Activities}

Plan of action and activities objective 1: Increase the human consumption of the small pelagic species

To increase the human consumption of anchovy, kilka and sardines in Iran it is necessary to be able to distribute the products over the whole country and thus increase the availability of products with an acceptable shelve life. The latter requires high quality raw material (cooled with ice or fast frozen) and proper processing of the raw material into products the people are willing to buy and pay for. Many different products made from small pelagic species are already on the market elsewhere in the world (e.g. frozen whole, canned whole, canned filleted, canned and smoked, canned with sauce, with olives, marinated, dried, fried, salted, fish sauce, anchovy paste etc.). We therefore suggest to investigate which of the available products made from small pelagic species already on the market elsewhere in the world would the Iranian people (repeatedly) buy and eat. This can be done using consumer research e.g. studying consumer preference and the use of direct market tests to evaluate and screen the different products to learn how consumers and retailers react to handling, using and repurchasing the different products to finally forecast future sales of the products and market potential of the products tested in the distribution territory of Iran. Products with sufficient market potential must be produced and commercialized together with or by the private sector. The knowledge needed to produce and 
commercialize the specific products needs to be implemented by learning or for example a joint venture with a company already selling such products elsewhere.

\begin{tabular}{|c|c|c|}
\hline Activity & Involvement & Expected results \\
\hline $\begin{array}{l}\text { 4. Kick-off meeting in Tehran } \\
\text { for both objectives }\end{array}$ & $\begin{array}{l}\text { WLR, WFBR, WecR, AREEO, } \\
\text { IFSRO, Shilat (IFO) and Mr } \\
\text { Smolders of the Dutch } \\
\text { embassy in Tehran }\end{array}$ & $\begin{array}{l}\text { Getting to know the } \\
\text { people involved in the } \\
\text { project and commitment } \\
\text { towards the project }\end{array}$ \\
\hline $\begin{array}{l}\text { 5. Making inventory of available } \\
\text { products, including product } \\
\text { and production information } \\
\text { using a desk study. }\end{array}$ & $\begin{array}{l}\text { Wageningen livestock } \\
\text { research (WLR) and } \\
\text { Wageningen Economic } \\
\text { Research (WEcR) }\end{array}$ & $\begin{array}{l}\text { Report } \\
\text { Selection of most } \\
\text { promising products in- } \\
\text { and outside Iran }\end{array}$ \\
\hline $\begin{array}{l}\text { 6. Design and execute a market } \\
\text { analyses of the products } \\
\text { made from small pelagics in } \\
\text { Iran }\end{array}$ & $\begin{array}{l}\text { Wageningen economic } \\
\text { research (WecR) }\end{array}$ & $\begin{array}{l}\text { Top } 3 \text { of products made } \\
\text { from small pelagics in } \\
\text { Iran with promising } \\
\text { market potential }\end{array}$ \\
\hline $\begin{array}{l}\text { 7. Consumer acceptance study } \\
\text { among Iranian consumers }\end{array}$ & $\begin{array}{l}\text { Wageningen economic } \\
\text { research (WEcR) }\end{array}$ & $\begin{array}{l}\text { Define consumer products } \\
\text { the Iranian people accept, } \\
\text { and expected to } \\
\text { (repeatedly) buy and eat. } \\
\text { WecR does design, guide, } \\
\text { analyze and discuss } \\
\text { results. The study itself } \\
\text { will be executed by our } \\
\text { Iranian colleagues or } \\
\text { Iranian subcontractor. }\end{array}$ \\
\hline $\begin{array}{l}\text { 8. Discuss results marketing } \\
\text { study and making plans for a } \\
\text { follow up with stakeholders } \\
\text { and private sector }\end{array}$ & $\begin{array}{l}\text { WLR, WFBR, WecR, AREEO, } \\
\text { IFSRO, Shilat (IFO) and Mr } \\
\text { Smolders of the Dutch } \\
\text { embassy in Tehran }\end{array}$ & $\begin{array}{l}\text { Go-No-Go and follow up } \\
\text { plan when having a Go }\end{array}$ \\
\hline $\begin{array}{l}\text { 9. X of the most preferred } \\
\text { products will be produced } \\
\text { using Iranian pelagic species } \\
\text { and are commercialized in } \\
\text { cooperation with or by the } \\
\text { private sector }\end{array}$ & $\begin{array}{l}\text { WLR, WFBR, WecR, private } \\
\text { companies Iran and } \\
\text { preferable the Netherlands }\end{array}$ & $\begin{array}{l}\text { X products put on the } \\
\text { market in cooperation } \\
\text { with private sector }\end{array}$ \\
\hline
\end{tabular}

Market analysis is a generic term used to describe a variety of qualitative and quantitative studies on products and/or product categories. Studies can focus on economic data, on rules, regulations and standards, consumer attitudes and/or the competitive advantage of the products studied over competing products and or providers. Market analysis are carried out for a wide-range of products. In the context of this study, we do not upfront propose to carry out a full market analysis for a full range of products. Instead, we propose to the following step-wise approach to ensure that each of subsequent phases focussed on the relevant products.

Phase 1: scoping of the study together with Iranian partners.

Phase 2: Inventory of products from anchovy, Kilka and sardines.

The current uses of anchovy, kilka and sardines in Iran are identified. This is baseline information, required to compare new human consumption products. Existing human food products from these species elsewhere in the world are identified (e.g. whole product frozen, canned whole, canned filleted, canned and smoked, canned with sauce, with olives, marinated, dried, fried, salted, fish sauce, anchovy paste etc.).

This phase consists of desk-study, looking at literature. EUMOFA database, FAO's GLOBEFISH, catalogues of whole-sellers, retail, combined with (telephone) interview and visits to trade fairs (if 
planning allows us to). The important global role of the Dutch pelagic industry allows us to easily contact various stakeholders established in the Netherlands.

This results in an overview of potential products using anchovy, kilka and sardines. Products are evaluated to assess to applicability in Iran; where we look at the required capital investments, global competition, trends in global production and expectations for global market outlook. This phase ends with the selection of 15 most promising products ( 5 for each species) of the fish species together with the client. These products are further studied in phase 3

\section{Phase 3: market analysis of selected products.}

In this phase we further analyse on the selected products for human consumption. For the market research, the following aspects are discussed: competition, actual and potential market size, market profitability, cost structure, distribution systems, trends and developments, key success factors.

This is done through desk-study research and interviews with the Iranian seafood sector. We suggest to cooperate with Iranian experts in this phase. Wageningen Research can provide questionnaires and instructions, local experts are in a better position to interview sector representatives. Regular Skype meetings with local experts are foreseen to secure results are useable for the analysis.

Results of this phase are a detailed market analysis for 15 human food products (5 per species). The results are discussed with the client to identify the top 6 most promising products that

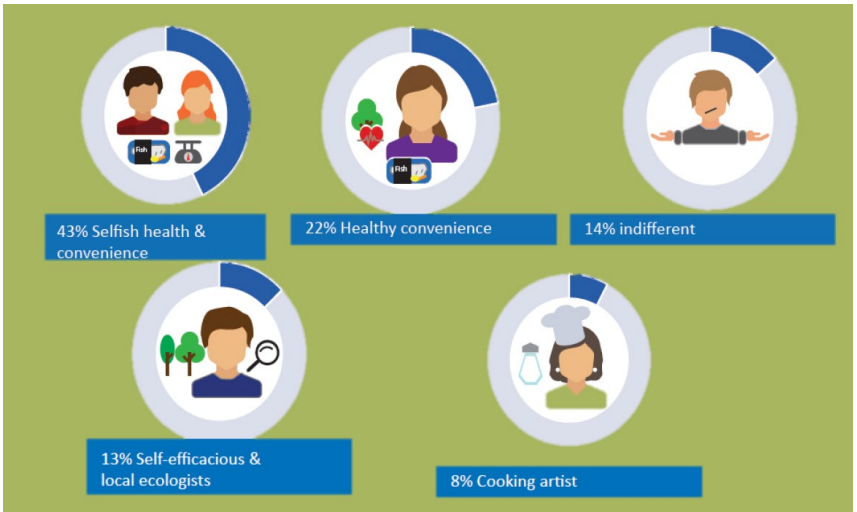

Figure 1: Illustration of segmentation (PrimeFish) will be used in the consumer preference study.

\section{Phase 4: Consumer preference study.}

In phase 4, the top 6 products ( 2 per species) are further studied to assess consumer preference. Iranian consumer data is collected in order to identify interesting segments and recommendations for a targeting and positioning strategy with a customized marketing mix (four P's: product, price, promotion, place).

In this phase, qualitative and quantitative methods are used. Qualitative method include interviews with consumers to identify consumers' motivations, (unmet) needs and first idea of segments. Subsequently, a quantitative approach is used for choice-based preference measurement (conjoint analysis). We suggest to use mobile devices (tablet, smartphone, enabling rapid interviewing of consumers at e.g. a fish market or retailer. This provides information to identify consumers preferences, willingness to pay and segments sizes.

In this step, we also foresee cooperation with an Iranian partner/subcontractor to support in data collection.

Results are a detailed insight into consumer preferences for the products studied, including insight into Willingness to Pay.

\section{Phase 5: follow-up plans.}

Based on the results of phases 2-4, a plan is drafted for market development of human food products from anchovy, kilka and/or anchovy. The plan describes market potential and give recommendations for marketing.

\section{Phase 6: Commercialisation.}

The last phase. Specific activities, costs and involvement are dependent on the results of the previous phases/steps and the involvement of industry and therefore cannot be specified at this moment. What we for example could do is:

- Open up Network in Europe

- $\quad$ Stakeholder analysis to identify potential partners 


\section{Plan of action and activities objective 2: Increase of the use of lantern fish for both fishmeal}

\section{and human consumption}

As lantern fish is frozen on board it is expected that the quality of the raw material is sufficient for further processing. Though, it is necessary to evaluate if the raw material is suitable for making products appropriate for human consumption. It is suggested to follow a stepwise approach towards the implementation of results:

- Evaluation quality raw materials and processing chain Production on pilot scale of raw fish oil from the lantern fish as it is delivered at this moment

- Improvement of the quality of this fish oil by implementation of hygienic and logistic measures in the fishing chain.

- Refining of the raw fish oil

- Realisation on lab scale of technology to produce protein of significant quality in terms of nutritional value and/or technical functionality

- $\quad$ Production on pilot scale of fish protein

- Diversification of the technology towards other fish species

\section{Activities Phase 1}

Legal aspects

The production of both the fish oil and the fish protein should fit within the legal boundaries of foodgrade production processes. Certain rules apply in this specific subject regarding:

- The raw material

- The by-products

- The valorisation processes

- The additives used in these processes

- The final products

The European legislation will be used as a benchmark for this project. It could be that the Iranian legislation differs to some extent. This will not be addressed in this project.

Quality improvement of the fish in the chain

The stabilisation of the raw material is very important for the quality of the products. Wageningen Research can provide insight and advice with respect to:

- Analyses of the current raw material and deliver parameters for the desired situation

- $\quad$ Risk assessment of the whole chain. The starting point is the intake of raw material and the endpoint is the delivery of the valorised products.

- Quality control. Provide suggestions for modification of- and coupling with the quality systematics of the fishing industry and the producer of the final products.

\section{Activities Phase 2}

Production and refining of fish oil without functional protein production

Fish oil is a vulnerable product. The healthy unsaturated fatty acids are sensitive to oxidation. The oxidation happens very fast, especially in the presence of catalysts such as enzymes or metal-ions. Besides this, micro-organisms can cause oxidation reactions. The state-of-the-art regarding fish oil production is an input of fresh fish and an output of fish oil and denatured protein meal (fish meal). For this process, technology is offered from commercial parties. The options of this technology for 
lantern fish will be assessed following the following steps:

- Approaching technology providers

- Production of raw fish oil samples on laboratory scale ( $<1$ litre)

- Pilot plant production trials for 5 days

- Quality assessment of the product

\section{Activities Phase 3}

Production and refining of fish oil and functional protein

Different technologies are available for fish oil production. The production of functional protein requires a technology that does not include a heating step before the protein has been removed from the oil fraction. Once the protein has been heated, it is denatured and loses most of its functional aspects. In previous projects Wageningen Research has demonstrated the production of sacroplasmatisch (blood-based) proteins and myofibrilair (muscle-based) proteins from fish and fish residue. This process can be the base for a technology development for protein production with functional properties from small fishes such as lantern fish. The following steps will be taken to demonstrate the feasibility of this concept:

- Contacting suppliers of technology

- Production of functional protein and fish oil on laboratory scale

- Assessment of the quality of the products

- Adjustment of the process parameters

- Pilot production during 5 days

- Production of representative samples

\section{Activities Phase 4}

- Potential market study with the samples, interest potential buyers

\section{Activities Phase 5}

- Discuss results and making plans for a follow up with stakeholders and private sector.

\section{Activities Phase 6}

- Commercialization of developed products by or together with the private sector

Currently, lantern fish is only used for the production of fishmeal. To check the possibility to add value toward this process it is optional to screen the sticky water from the fishmeal production plant for the presence of bioactive peptides. 


\begin{tabular}{|c|c|c|}
\hline Activity & Involvement & $\begin{array}{l}\text { Expected } \\
\text { results }\end{array}$ \\
\hline $\begin{array}{l}\text { 1. Evaluation quality raw } \\
\text { materials and processing } \\
\text { chain including the legal } \\
\text { aspects and quality } \\
\text { improvement of the fish in } \\
\text { the chain }\end{array}$ & $\begin{array}{l}\text { Wageningen Livestock Research (WLR) } \\
\text { and Wageningen Food and biobased } \\
\text { Research (WFBR) }\end{array}$ & Report \\
\hline $\begin{array}{l}\text { 2. Production on pilot scale of } \\
\text { raw fish oil from the } \\
\text { lantern fish as it is } \\
\text { delivered at this moment; } \\
\text { Production and refining of } \\
\text { fish oil without functional } \\
\text { protein production }\end{array}$ & $\begin{array}{l}\text { Wageningen livestock research (WLR) } \\
\text { and Wageningen Food and biobased } \\
\text { Research (WFBR) in cooperation with } \\
\text { UNIDO processing center (Guilan } \\
\text { province) }\end{array}$ & $\begin{array}{l}\text { Report and lab } \\
\text { scale production } \\
\text { of half fabricates } \\
\text { from lantern fish }\end{array}$ \\
\hline $\begin{array}{l}\text { 3. Production and refining of } \\
\text { fish oil and functional } \\
\text { protein: Realisation on lab } \\
\text { scale of technology to } \\
\text { produce protein of } \\
\text { significant quality in terms } \\
\text { of nutritional value and/or } \\
\text { technical functionality. } \\
\text { Production on pilot scale of } \\
\text { fish protein, production of } \\
\text { Production of } \\
\text { representative samples }\end{array}$ & $\begin{array}{l}\text { Wageningen livestock research (WLR) } \\
\text { and Wageningen Food and biobased } \\
\text { Research (WFBR) in cooperation with } \\
\text { Persian Gulf and Oman Sea ecology } \\
\text { research Institute (Hormozgan } \\
\text { province) }\end{array}$ & $\begin{array}{l}\text { Report and } \\
\text { representative } \\
\text { samples }\end{array}$ \\
\hline $\begin{array}{l}\text { 4. Market study with the } \\
\text { samples, interest potential } \\
\text { buyers }\end{array}$ & WLR, WFBR possibly WecR & Report \\
\hline $\begin{array}{l}\text { 5. Discuss results and } \\
\text { making plans for a follow } \\
\text { up with stakeholders and } \\
\text { private sector }\end{array}$ & $\begin{array}{l}\text { WLR, WFBR, WecR, AREEO, IFSRO, } \\
\text { Shilat (IFO) and Mr Smolders of the } \\
\text { Dutch embassy in Tehran }\end{array}$ & $\begin{array}{l}\text { Go-No-Go and } \\
\text { follow up plan } \\
\text { when having a Go }\end{array}$ \\
\hline $\begin{array}{l}\text { 6. Commercialization of } \\
\text { developed products by or } \\
\text { together with the private } \\
\text { sector }\end{array}$ & $\begin{array}{l}\text { WLR, WFBR, WecR, private companies } \\
\text { Iran and preferable the Netherlands }\end{array}$ & $\begin{array}{l}X \text { products put on } \\
\text { the market }\end{array}$ \\
\hline $\begin{array}{l}\text { 7. Optional: Diversification of } \\
\text { the technology towards } \\
\text { other fish species }\end{array}$ & $\begin{array}{l}\text { Wageningen livestock research (WLR) } \\
\text { and Wageningen Food and biobased } \\
\text { Research (WFBR) in cooperation with } \\
\text { Persian Gulf and Oman Sea ecology } \\
\text { research Institute (Hormozgan } \\
\text { province) }\end{array}$ & \\
\hline $\begin{array}{l}\text { 8. Optional: Screening for } \\
\text { bioactive peptides: } \\
\text { a) screen sticky water } \\
\text { fishmeal production plant } \\
\text { b) screen protein } \\
\text { hydrolsate from lantarn } \\
\text { fish }\end{array}$ & $\begin{array}{l}\text { Wageningen livestock research (WLR) } \\
\text { and Wageningen Food and biobased } \\
\text { Research (WFBR) }\end{array}$ & \\
\hline
\end{tabular}

\section{Management aspects}

\subsection{Organisation}

The project will be executed in collaboration with the IFSRI (Iranian Fisheries Sciences Research Institute) and AREOO (Agricultural Research Education and Extension Organization). The Dutch Research institutes that will be involved are Wageningen Livestock Research (WLR), Wageningen Food \& Biobased Research (WFBR) and Wageningen Economic Research. For some tasks it might be wise to involve Iranian partners e.g. phase 3 and or 4 from the marketing study: "interview and data collection during the marketing study". 


\subsection{Planning}

To be discussed with stakeholders at a later moment.

\subsection{Management of deviations}

There may occur deviations in the project implementation, for example due to:

1. The time schedule is not met. When the bottlenecks are identified that cannot be resolved internally.

2. The project differs substantially from the initial plan because:

a) bottlenecks occur that require a substantial revision;

b) the client requires other product demands;

In both cases, consultation is needed with all stakeholders, to determine and agree on the new (written) agreements.

\section{Communication}

All parties involved are of equal importance for the proper execution of the project. During the project phone/Skype project meetings will be organised to discuss the progress of the trial. In addition personal meetings are involved. After completion of the project the results will be reported in a Wageningen report template. 


\section{Work plan 2:}

\section{Project proposal/plan Wageningen Livestock Research}

Improvement of the fish value chain in Iran: "Increase of the use of lantern fish for both fishmeal and human consumption phase 1".

Jeroen Kals 


\section{Description}

\subsection{Introduction and problem definition}

During the fact finding and goal establishing mission of 23rd to the 29th of September 2017, prof Komen and Dr Kals from Wageningen university, together with Mr Smolders of the Dutch embassy in Tehran, and Mr Lomans of the Ministry of Agriculture, Nature and Food quality in the Netherlands visited IFSRO research institutes in Anzali and Ahwaz, fish processing companies in the Persian gulf, and two institutes of the Iranian Fisheries Organisation or Shilat (IFO). Based on discussions with the Iranian deputy minister and colleagues from IFSRO, for fish processing, four objectives were identified as joint research and cooperation priorities.

1. to increase the human consumption of the small pelagic species like anchovy, kilka and sardines currently used for fishmeal. 2. To increase the resource use efficiency of tuna by products 3. the increase of the use of lantern fish for both fishmeal and human consumption and 4 . The development of products using carp as a raw material.

For each of the four goals a brief introduction, and suggested plan of action was described in the report: "Improvement of the fish value chain in Iran: introduction of modern breeding technology, product innovation and value creation in fish and fish products".

For processing, The Islamic Republic of Iran has recently given priority to research objective 1 and 3 and asked Wageningen University and Research to write a project proposal for the two priority objectives. After discussing the project proposal during the Skype meeting on the 12th of February 2019 it was decided to focus on the first steps of topic

3: "the increase of the use of lantern fish for both fishmeal, fish oil and human consumption".

\subsection{Objective}

\section{Increase of the use of lantern fish for both fishmeal and human consumption phase 1}

\section{Introduction and problem definition}

According to the data presented the maximum sustainable yield (MSY) of lantern fish is much higher than the current catch, which is about 15 kton a year. The goal of the Iranian government is to increase lantern fish landings to 100 kton in the next five years. Currently, lantern fish is only used for the production of fishmeal. However, the goal of the Iranian government is to allocate or use $50 \%$ of the landings for human consumption.

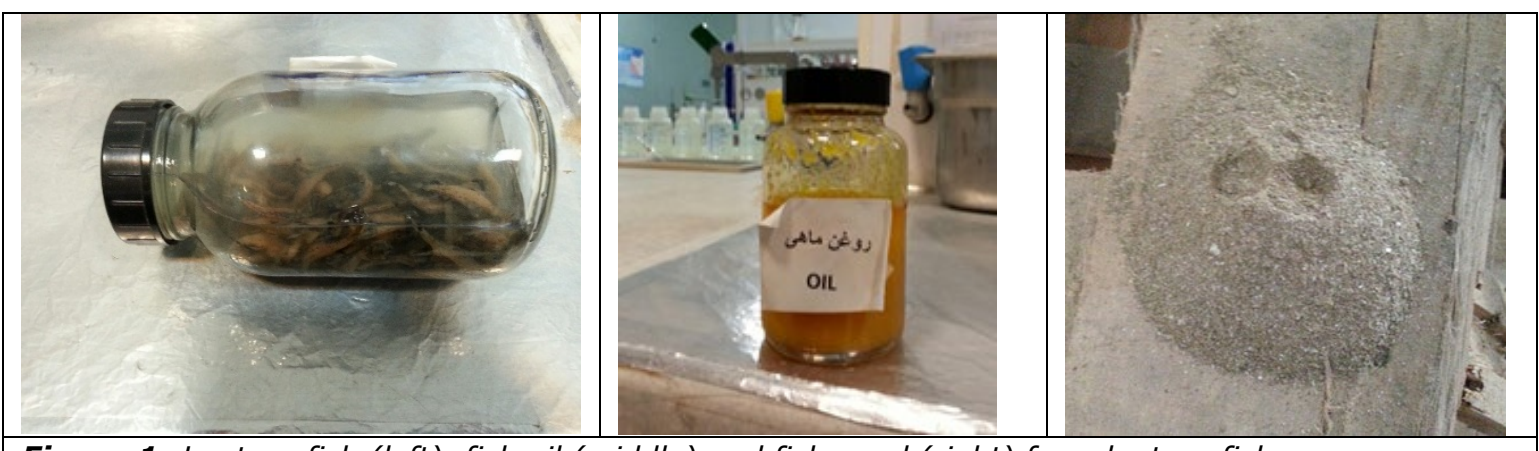

Figure 1: Lantern fish (left), fish oil (middle) and fish meal (right) from lantern fish.

\subsection{Results}

The Wageningen partners (WLR, WFBR and WECR) will jointly prepare a report in English describing the materials and methods, results and conclusions of the project. 


\subsection{Boundaries, conditions and restrictions}

Availability of raw materials

All necessary raw materials (fish) not available in the Netherlands and needed for the project (e.g. sufficient amounts of lantern fish) will be provided by IFSRI (Iranian Fisheries Sciences Research Institute) and AREOO (Agricultural Research Education and Extension). It is the responsibility of IFSRI and AREOO to make them available for research in the Netherlands.

\subsection{Activities}

\section{Plan of action and activities phase 1}

As lantern fish is frozen on board it is expected that the quality of the raw material is sufficient for further processing. Though, it is necessary to evaluate if the raw material is suitable for making products appropriate for human consumption. In the previous proposal it was suggested to follow a stepwise approach towards the implementation of results. However, after discussing the project proposal during the Skype meeting on the 12th of February 2019 it was decided to delete some of the phases or steps and focus on the following steps:

1. Analyses of current raw material

2. Production of raw fish oil samples on laboratory scale ( $<1$ litre)

3. Quality assessment of the product

4. Production of functional protein and fish oil on laboratory scale

5. Quality assessment of the product

6. Production of representative samples

7. Potential added value using lantern fish

As for the required analyses it is envisaged to have close collaboration with IFSRI and AREOO in order to make optimal use of existing experimental facilities in Iran. In this way the budget requirements for analysis by WFBR in Wageningen is kept to the minimum.

\section{Production of fish oil without functional protein production}

Fish oil is a vulnerable product. The healthy unsaturated fatty acids are sensitive to oxidation. The oxidation happens very fast, especially in the presence of catalysts such as enzymes or metal-ions. Besides this, micro-organisms can cause oxidation reactions. The state-of-the-art regarding fish oil production is an input of fresh fish and an output of fish oil and denatured protein meal (fish meal). For this process, technology is offered from commercial parties. The options of this technology for lantern fish will be assessed following the following steps:

- $\quad$ Approaching technology providers

- $\quad$ Production of raw fish oil samples on laboratory scale ( $<1$ litre)

- $\quad$ Quality assessment of the product

Production and refining of fish oil and functional protein

- Different technologies are available for fish oil production. The production of functional protein requires a technology that does not include a heating step before the protein has been removed from the oil fraction. Once the protein has been heated, it is denatured and loses most of its functional aspects. In previous projects Wageningen Research has demonstrated the production of sacroplasmatisch (blood-based) proteins and myofibrilair (muscle-based) proteins from fish and fish residue. This process can be the base for a technology development for protein production with functional properties from small fishes such as 
lantern fish. The following steps will be taken to demonstrate the feasibility of this concept:

- Contacting suppliers of technology

- Production of functional protein and fish oil on laboratory scale

- Assessment of the quality of the products

\section{Optional future steps}

- $\quad$ Potential market study with the samples, interest potential buyers

- Discuss results and making plans for a follow up with stakeholders and private sector

- Commercialization of developed products by or together with the private sector

\section{Management aspects}

\subsection{Organisation}

The project will be executed in collaboration with the IFSRI (Iranian Fisheries Sciences Research Institute) and AREOO (Agricultural Research Education and Extension Organization). The Dutch Research institutes that will be involved are Wageningen Livestock Research (WLR), Wageningen Food \& Biobased Research (WFBR) and Wageningen Economic Research. As for the required analyses it is envisaged to have close collaboration with IFSRI and AREOO in order to make optimal use of existing experimental facilities in Iran. In this way the budget requirements for analysis by WFBR in Wageningen is kept to the minimum.

\subsection{Planning}

To be discussed with stakeholders at a later moment.

\subsection{Management of deviations}

There may occur deviations in the project implementation, for example due to:

1. The time schedule is not met. When the bottlenecks are identified that cannot be resolved internally.

2. The project differs substantially from the initial plan because:

a) bottlenecks occur that require a substantial revision;

b) the client requires other product demands;

In both cases, consultation is needed with all stakeholders, to determine and agree on the new (written) agreements.

\section{Communication}

All parties involved are of equal importance for the proper execution of the project. During the project phone/Skype project meetings will be organised to discuss the progress of the trial. In addition personal meetings are involved. After completion of the project the results will be reported in a Wageningen report template. 
Appendix 4: Presentations workshop fish breeding 


\section{Selective breeding in Aquaculture}

Hans Komen, Animal breeding and genomics group

Tehran, Iran 12/6, 2019

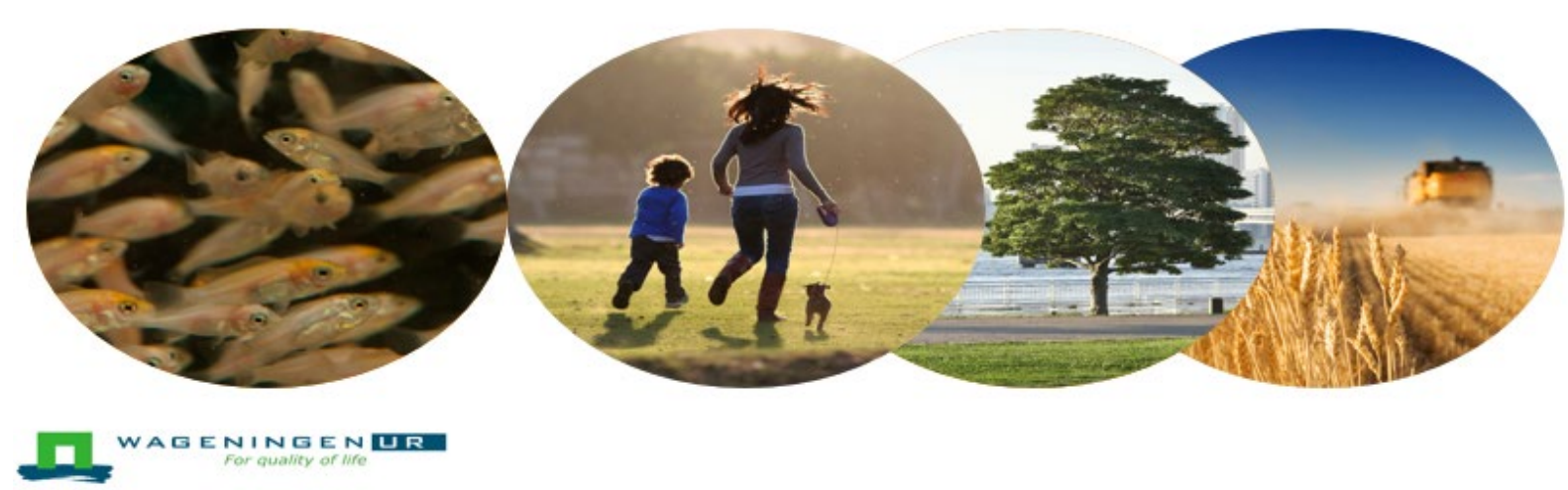

This workshop

- Short Introduction
- Principles of a breeding program
- Example I: trout
- Example II: seabass and seabream
- Example III: tilapia

WAGENINGEN UR 


\section{Organisation of Breeding in aquaculture}

- Large specialized breeding companies

- National, or cooperative Breeding programs

- Commercial fry producers with R\&D support

- Large producers with integrated breeding program

- Many relatively small companies with little or no breeding activities

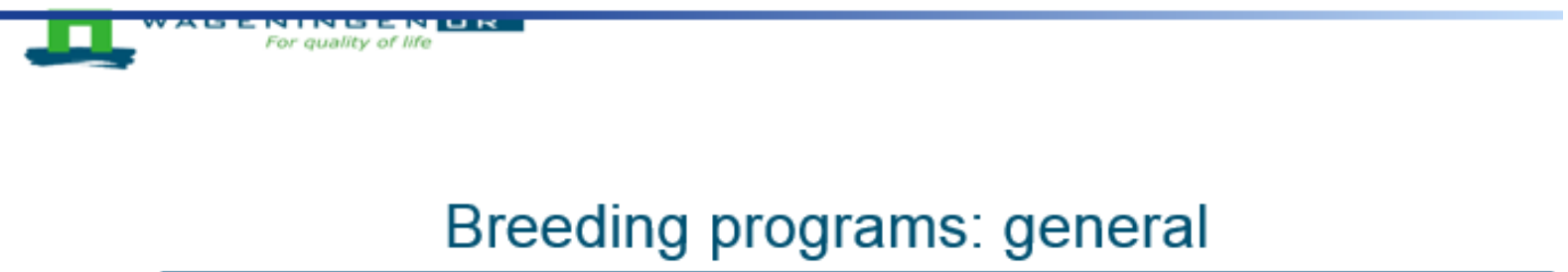

Reasons for a breeding program:

Poor growth (wild species)

Poor FCR

Large variation in harvest weight

inbreeding depression

increase profitability is the most important issue... 


\section{Breeding programs: general}

breeding programs are complex, expensive and risky, investment because...

Need larger numbers of broodstock

Need family rearing, tagging, genotyping

(tracing pedigrees)

No genetic protection!

Only long term benefits, no quick wins

\section{Steps in a breeding program}

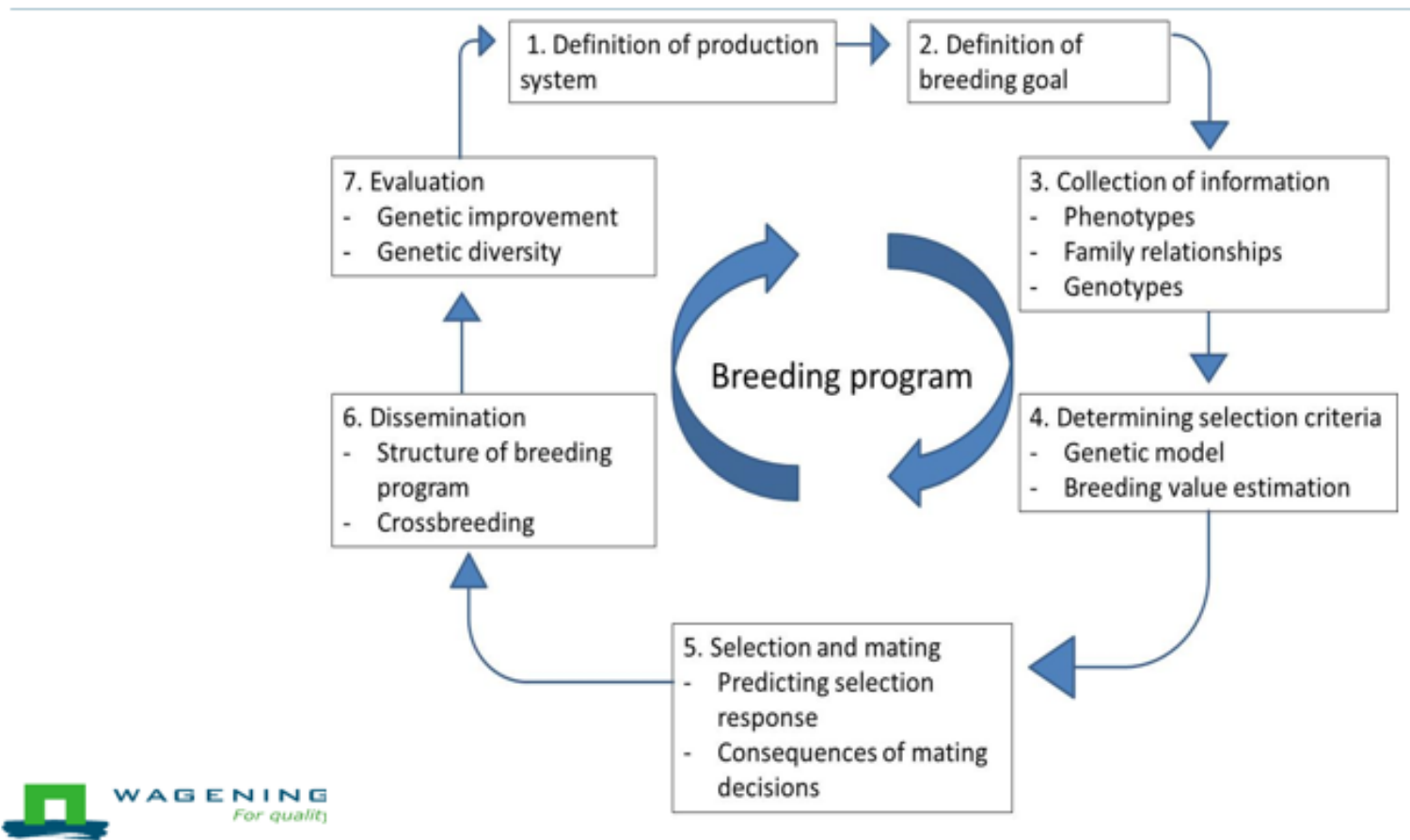




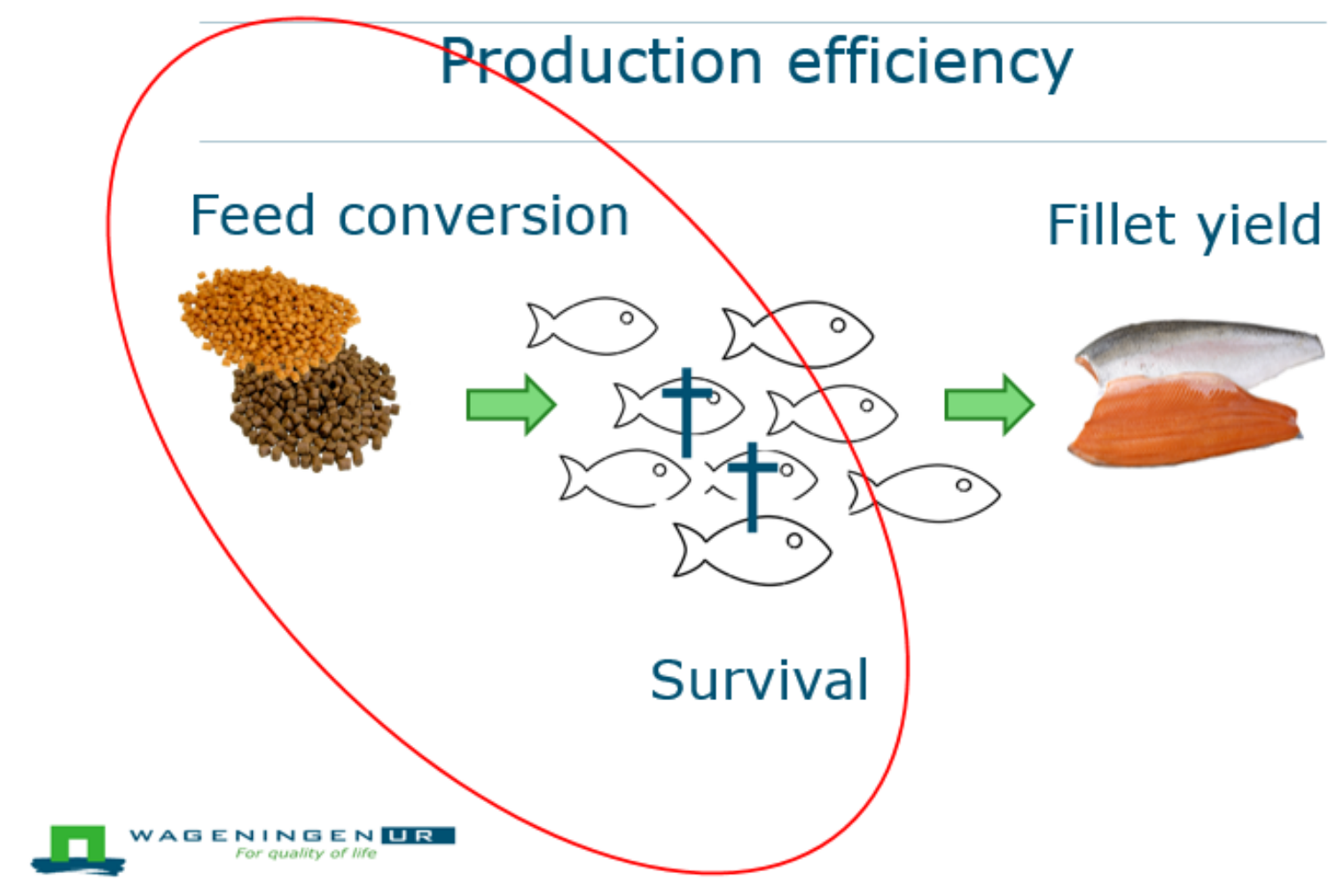

Aquaculture selective breeding

- Most large breeding programs now focus on

- Growth, Fat-\%

- Fillet yield

- QTL for disease resistance

- A lot of genetics research is currently done on

- Association of disease traits with GWA / QTL

- Genomic selection... 


\section{Divsion and outsourcing of tasks}

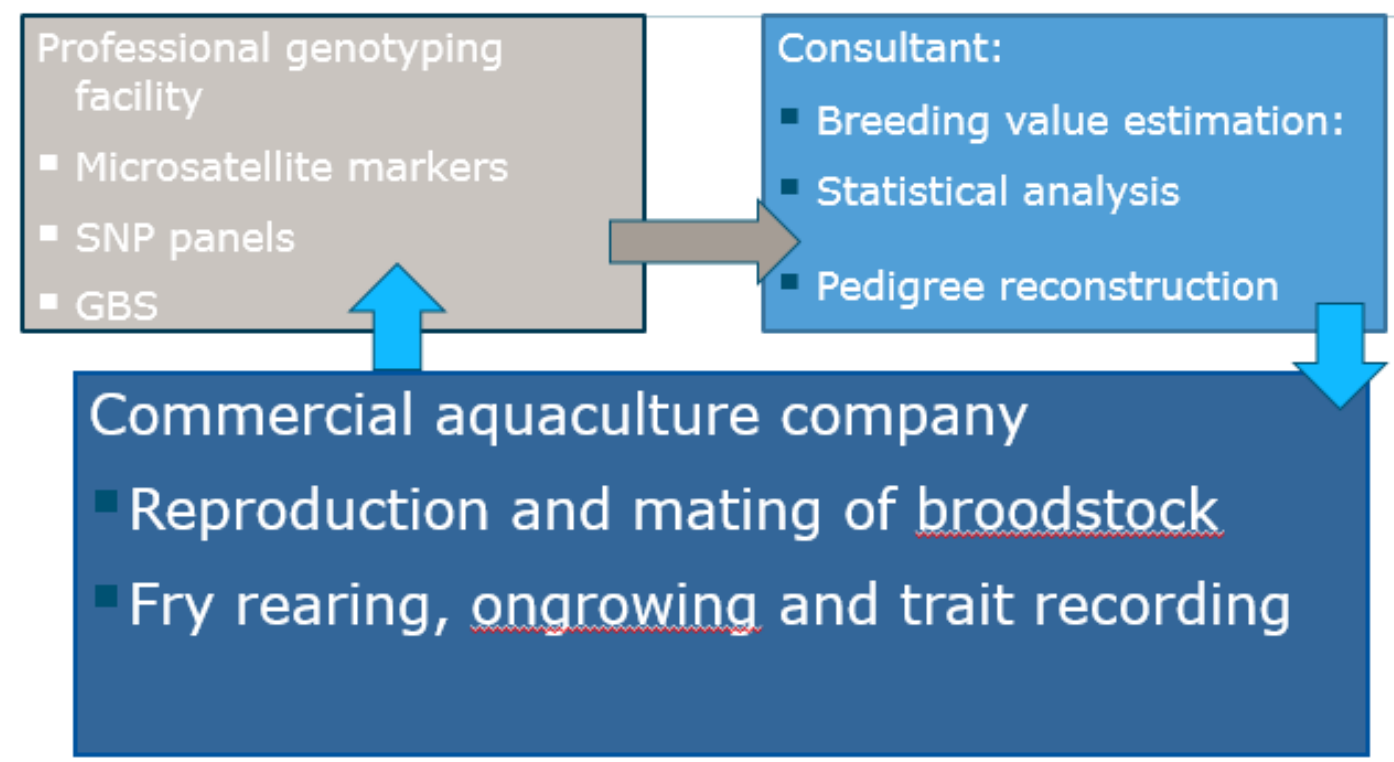

\section{Major cost factors}

$>$ Broodstock

$>$ Mating design

Full sib family rearing (fry)

$>$ Pedigree recording (tagging, genotyping)

$>$ Trait recording

Sib testing for additional traits 


\section{Broodstock size and size of test population}

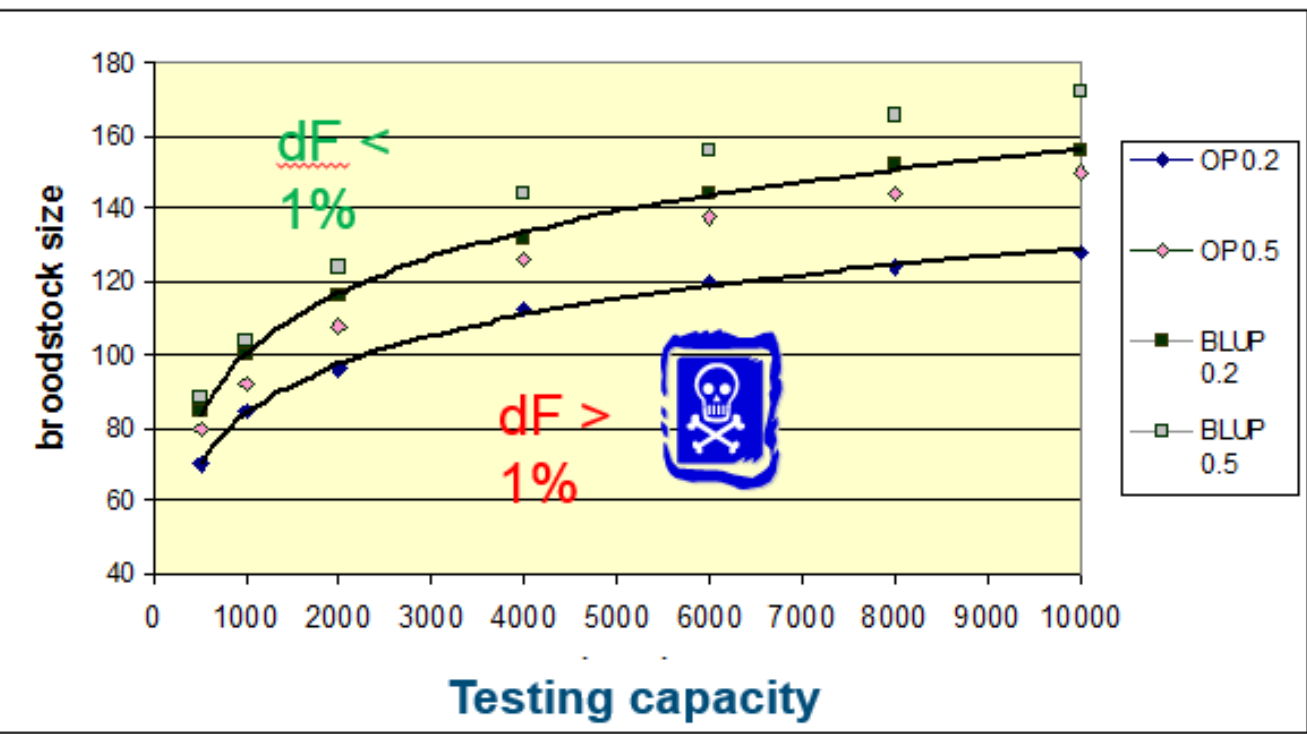

WAGENINGEN UR

Mating designs

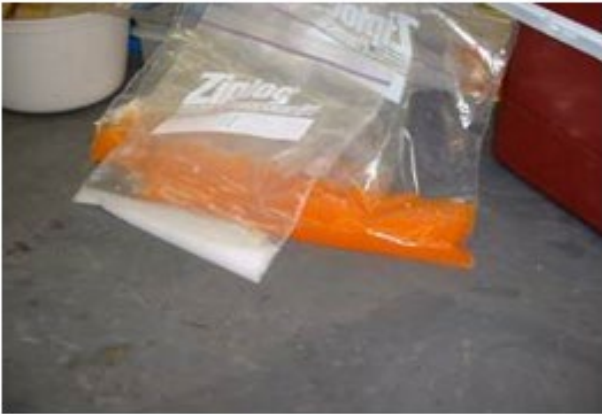

natural

spawning ...
Controlled: factorial mating Rainbow trout
Nile tilapia

Sea

Bass/Bream

Barramundi 
natural mating: unequal contributions

Leads to inbreedina

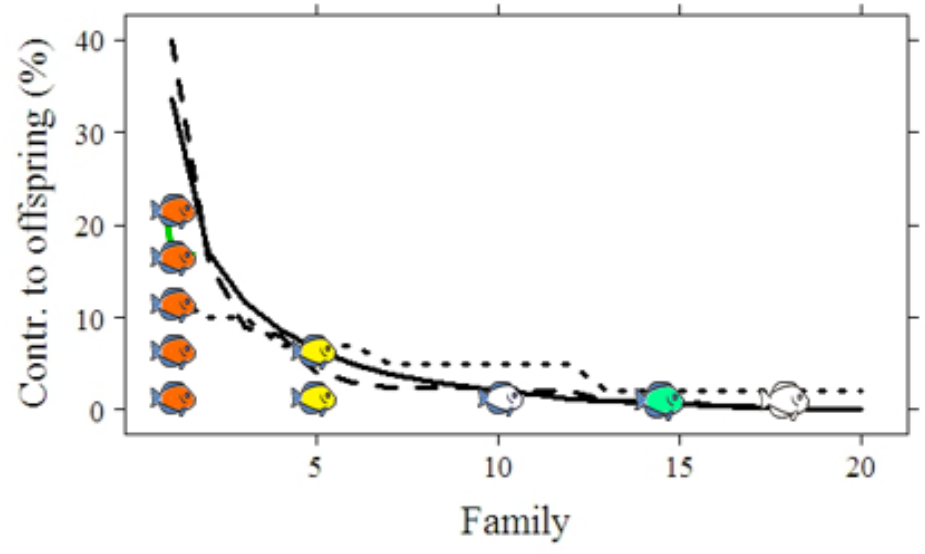

Mating systems: natural mating

- Natural mating in a breeding program:

- Strong control on inbreeding needed

- Control of parental genetic contribution to next generations

- Genotyping required!

- Or large broodstocks... consequences!

- we estimated:

- 150 parents with BLUP + genotyping + OC

- $300+$ for mass selection 


\section{Pedigree-Tagging}

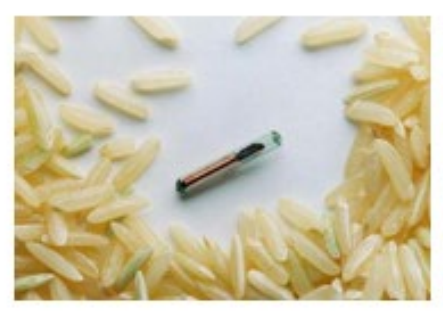

1-2 euro

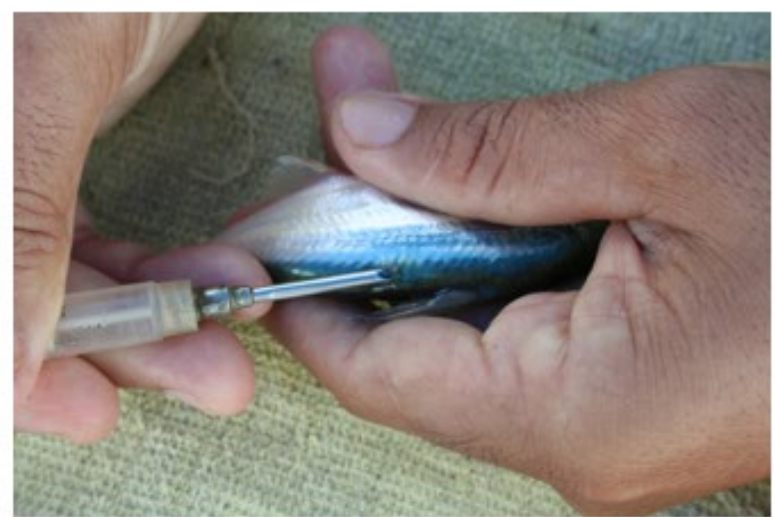

\section{Pedigree-genotyping}

- Reconstruct relationships:

- DNA markers, GBS: 10-30 euro/fish

- Pedigree reconstruction/genomic selection

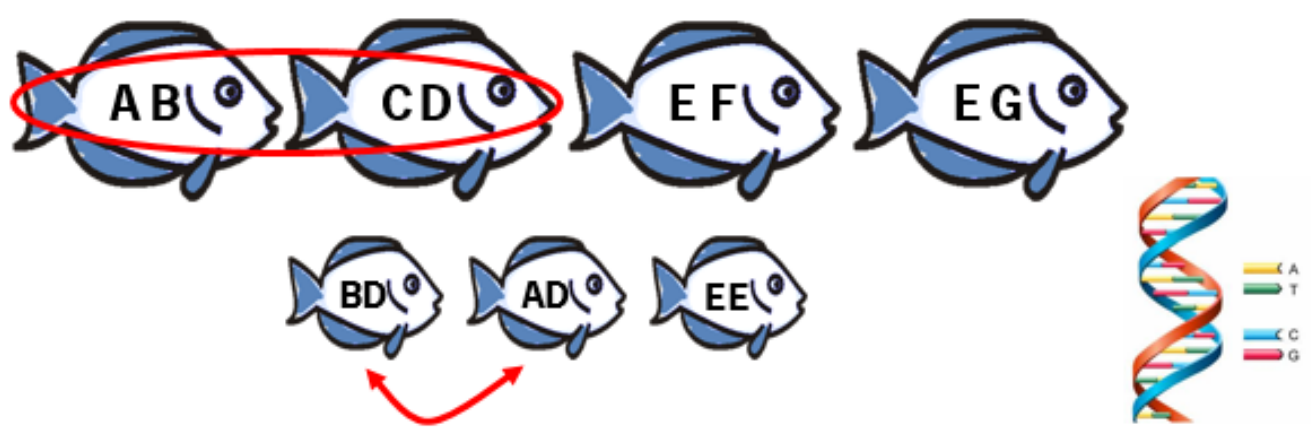




\section{Family rearing until tagging......}

Keep family rearing conditions uniform until tagging

Expensive......

and impossible when you have natural mating

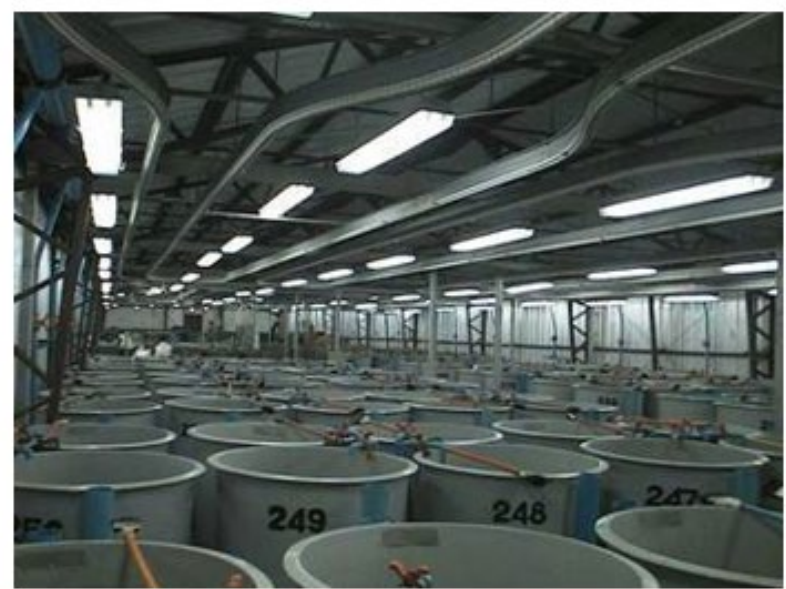

\section{Trait recording}

Stocking weight - Harvest weigth

Survival

Growth rate

Fat- $\%$

Shape

Slaughter traits on relatives - fillet yield 


\section{Our solution - low cost breeding program}

A simple and cheap breeding program,

That can be run on farm, by farm personnel

That avoids inbreeding

And produces better growing fish

Maximize profits...

$>$ Focus on the most important trait

$>$ Selection environment $=$ production environment

$>$ Maximize gain at acceptable rates of inbreeding

$\checkmark$ Focus on first 5-10 years! 


\section{Principles of a low-cost BP}

Reduce costs...

$>$ No tagging.. own performance selection (mass sel.)

$\checkmark$ Reconstruct pedigree of parents

Optimize use of broodstock

Maximize use of facilities

cost reduction

$>$ Broodstock

$>$ Mating design: species dependent

$>$ Full sib family rearing (fry)

$>$ Pedigree recording: only on selected fish

$>$ Trait recording: in production environment

Sib testing for additional traits 


\section{Benefits of selection in seabream: company level}

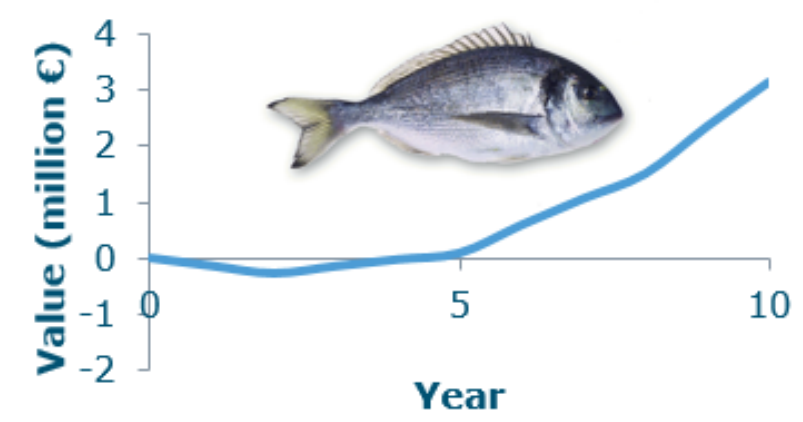

In year 10, Net Present Value $=€ 3.2$ million. 


\section{Examples Aquaculture breeding programs}
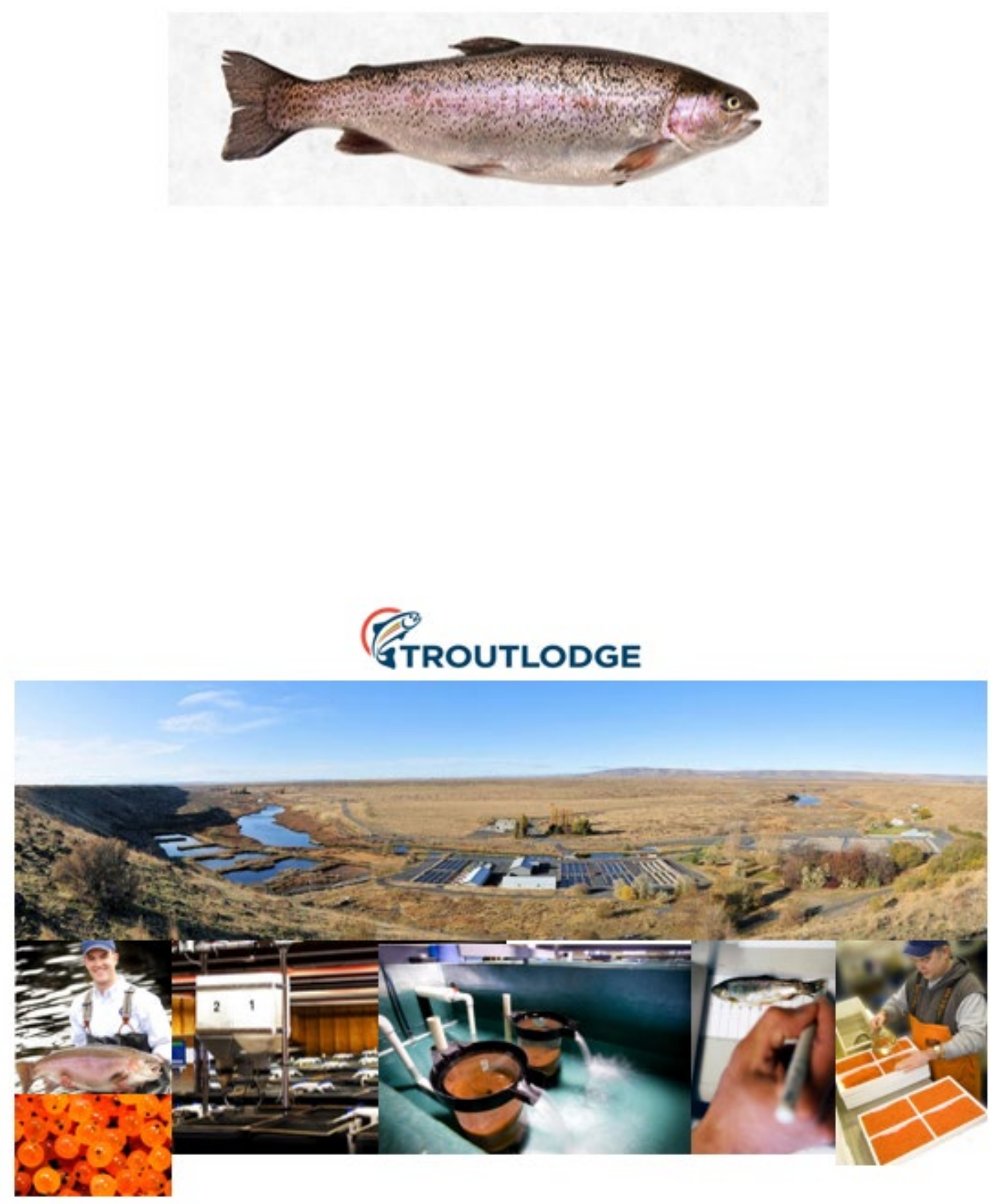


\section{Customers = "most important"}

- A breeding plan for customers

- Survey + Farm visit

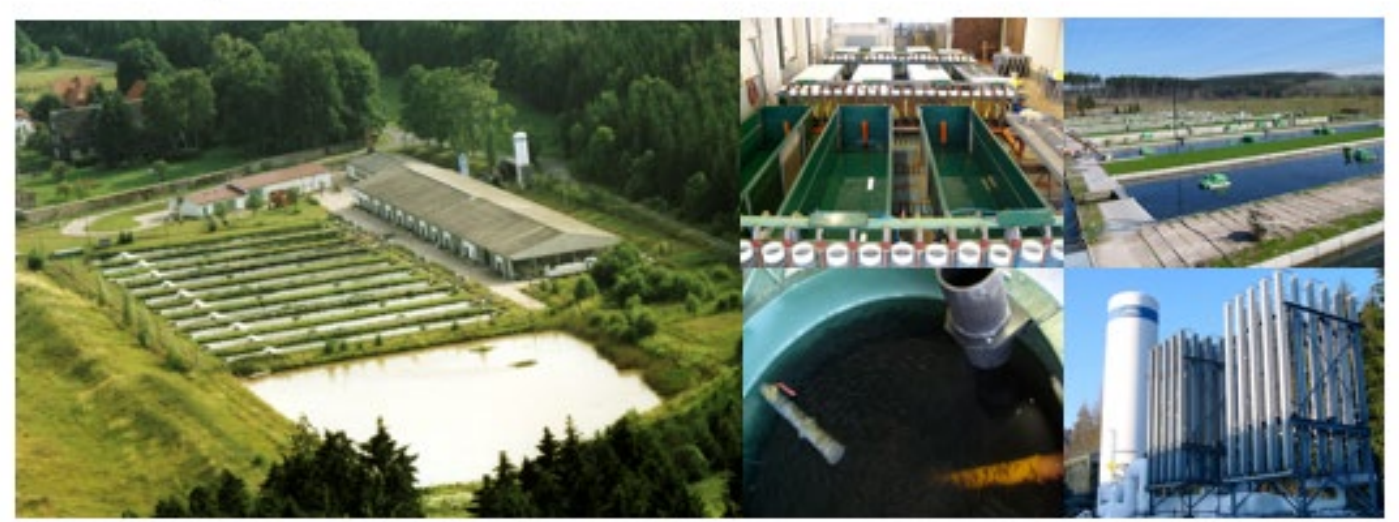

Forellenzucht Trostadt GbR

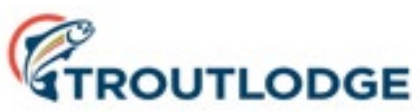

\section{Customer Survey: Environment}
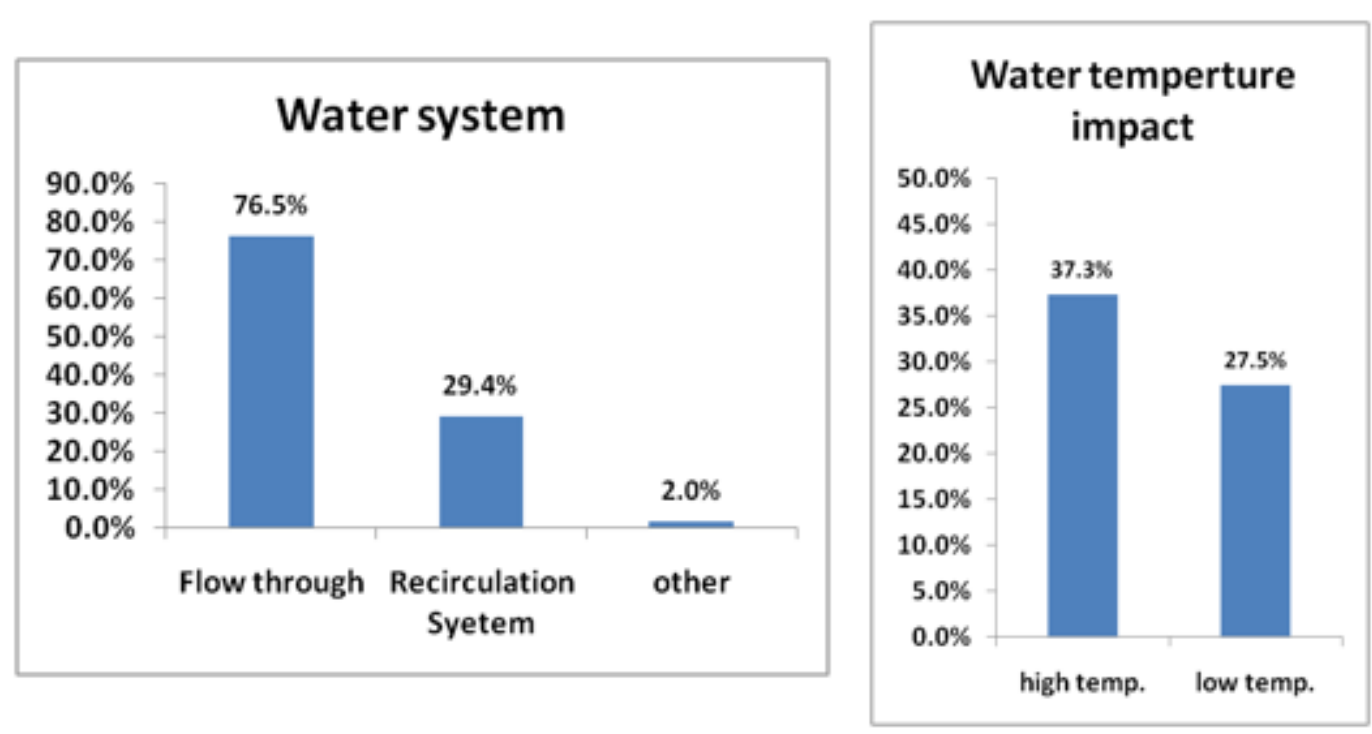


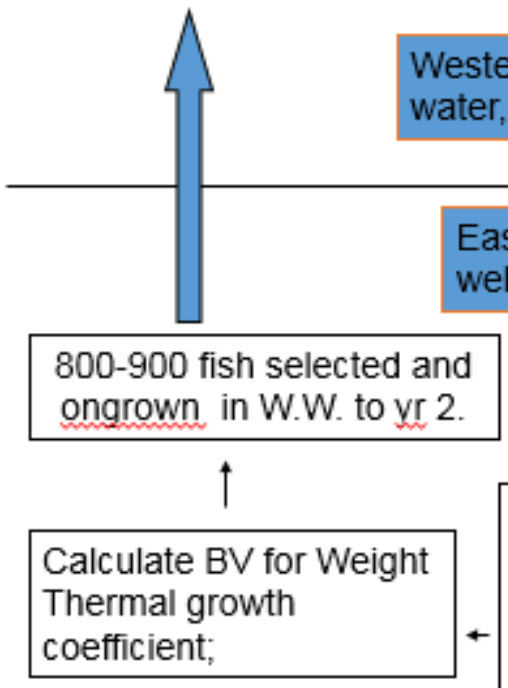

Western Washington, $10 \mathrm{C}$, spring water, feeding $0.5 \%$ bw/dy

Eastern Washington, $14 \mathrm{C}$ well water, feeding ad ib.

\section{Customer Survey: Variation of traits}

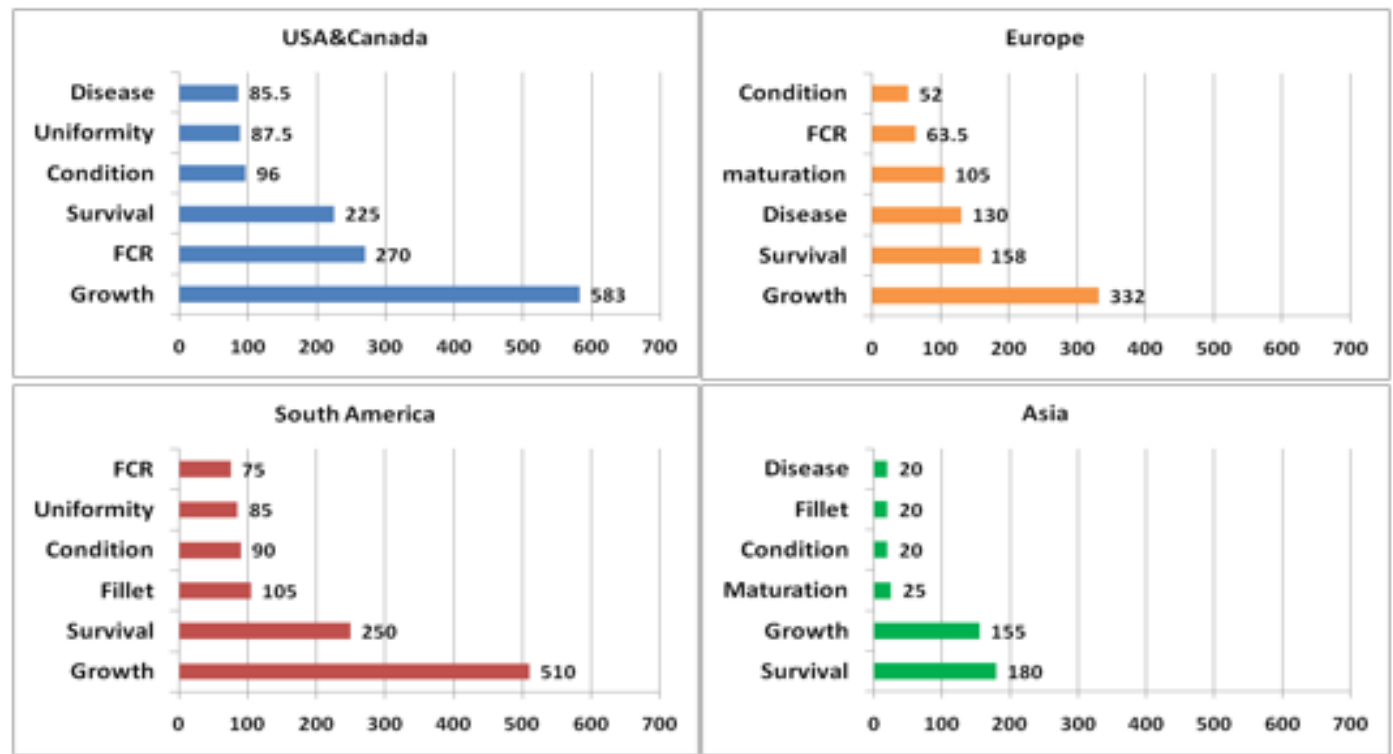




\section{Broodstock facilities (10 C, well water)}

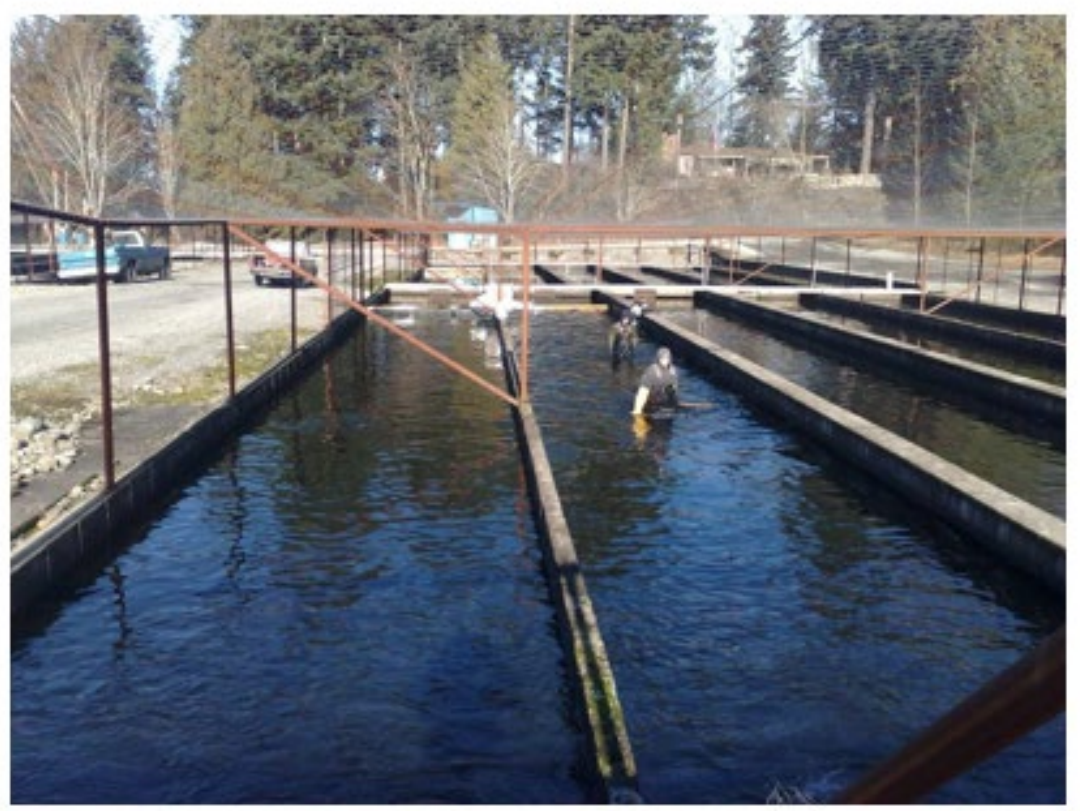

Stripping and fertilization room

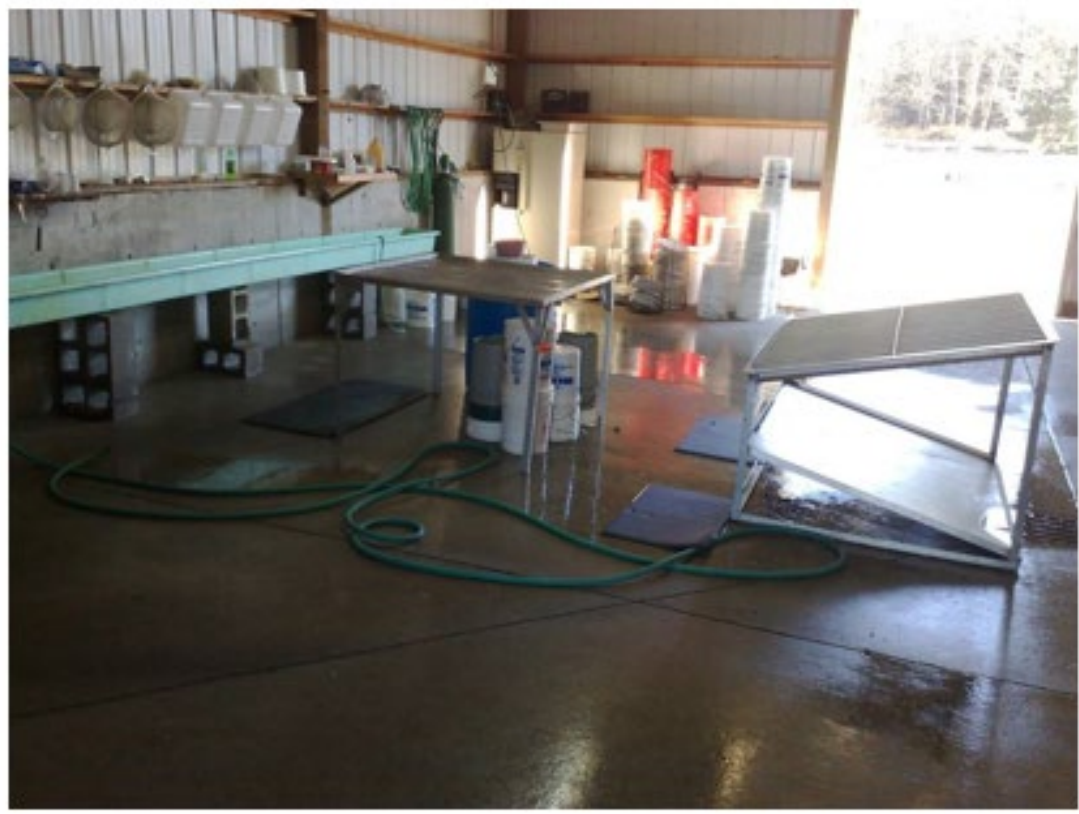




\section{Egg incubators}

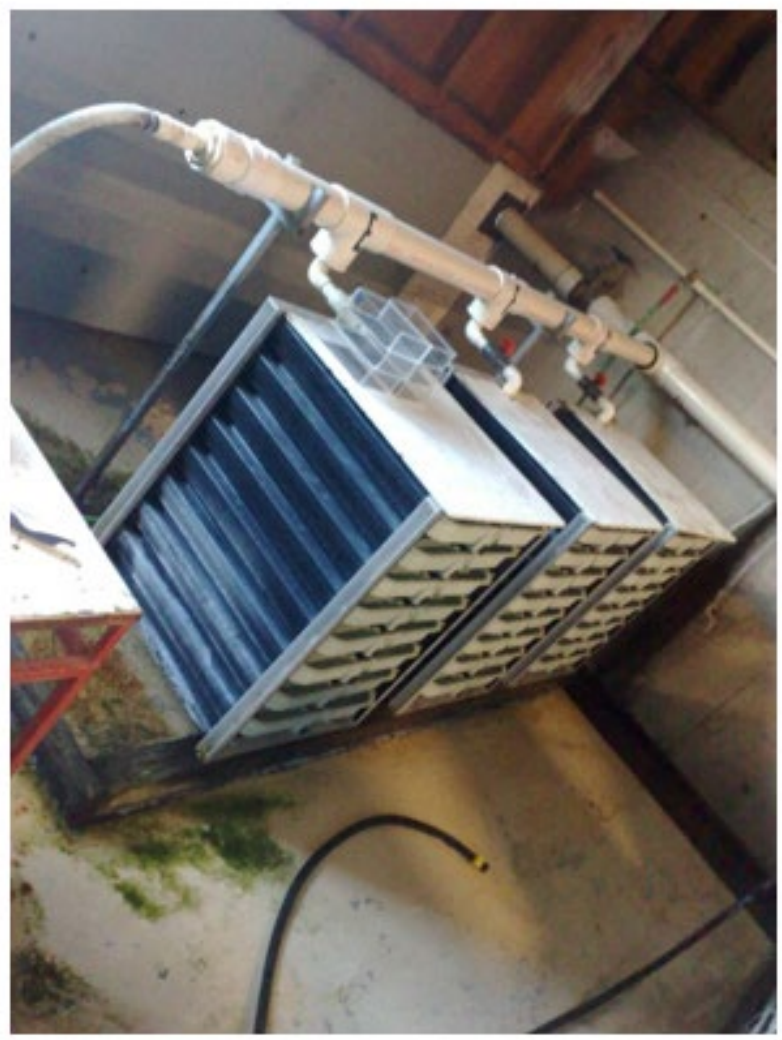

\section{Eyed eggs}

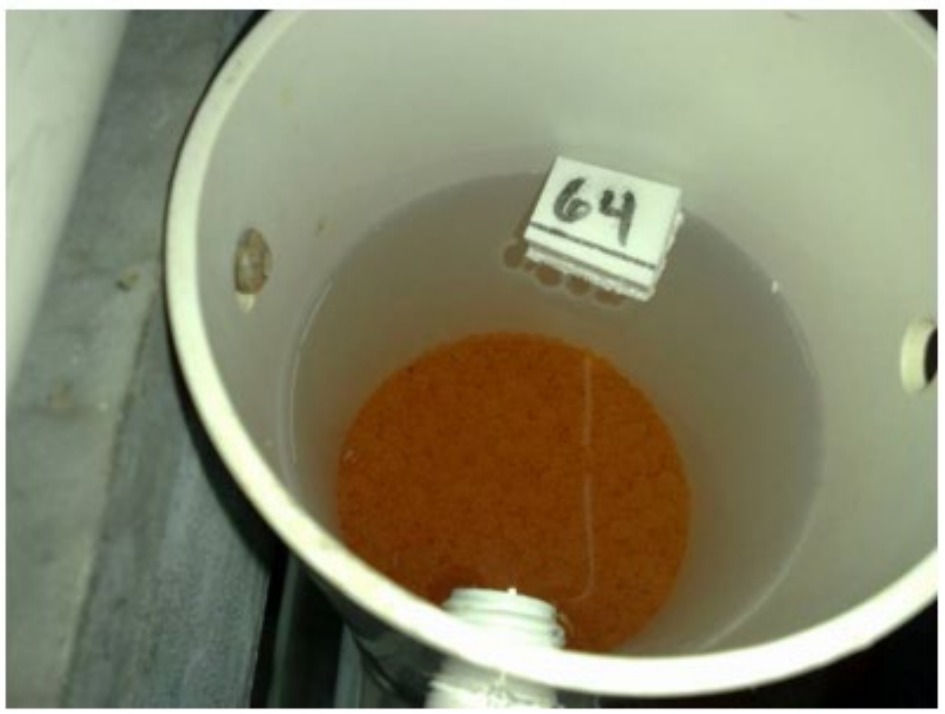




\section{Full sib family rearing}

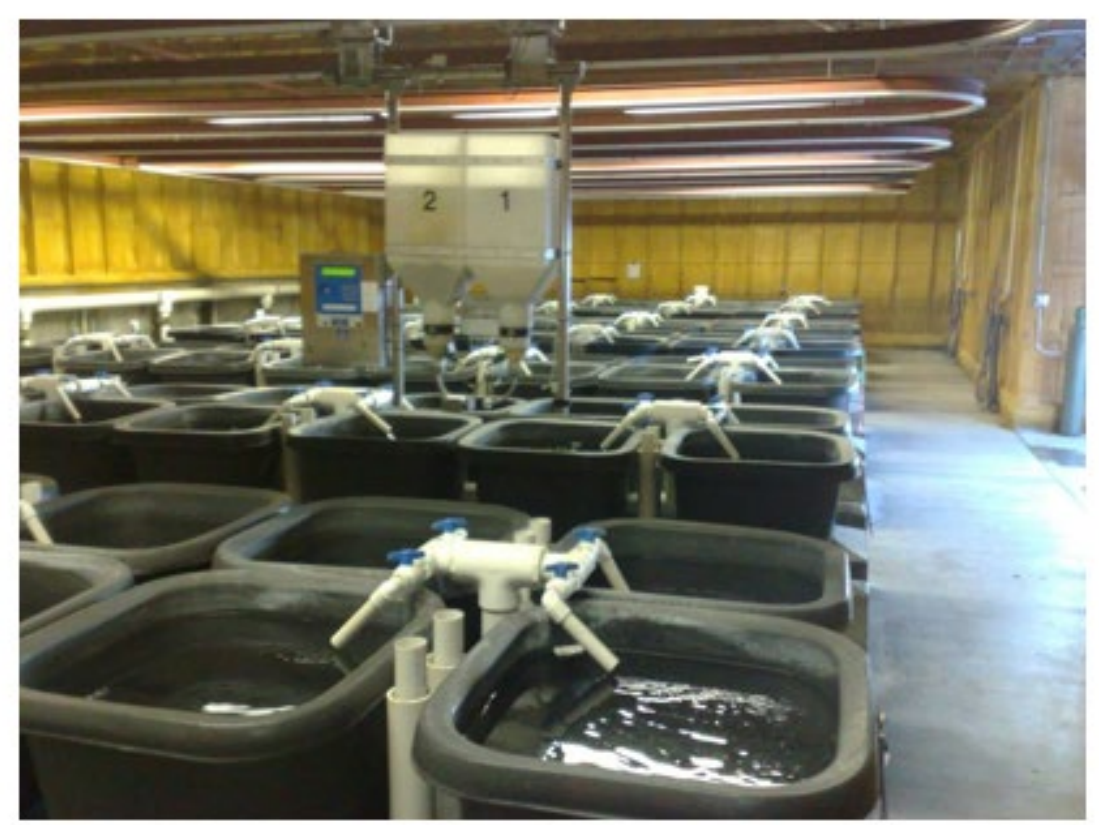

one family 
Methyltestosteron treatment to make $\mathrm{xx}$ males.

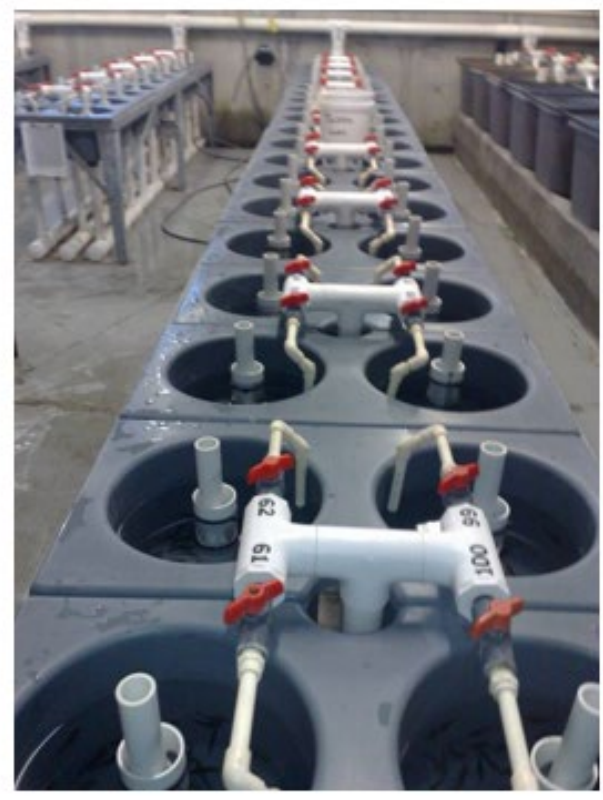

Tagging size

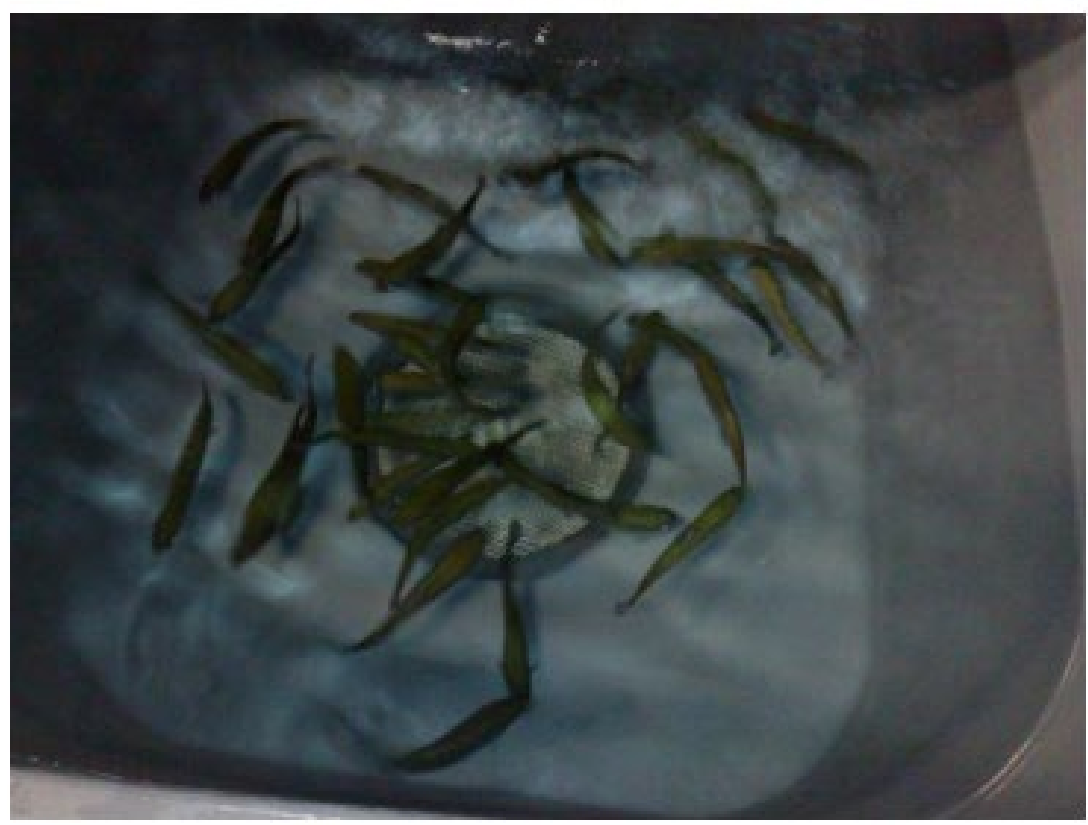




\section{Ongrowing, communal rearing, to 400 and $1 \mathrm{~kg}$ weights}
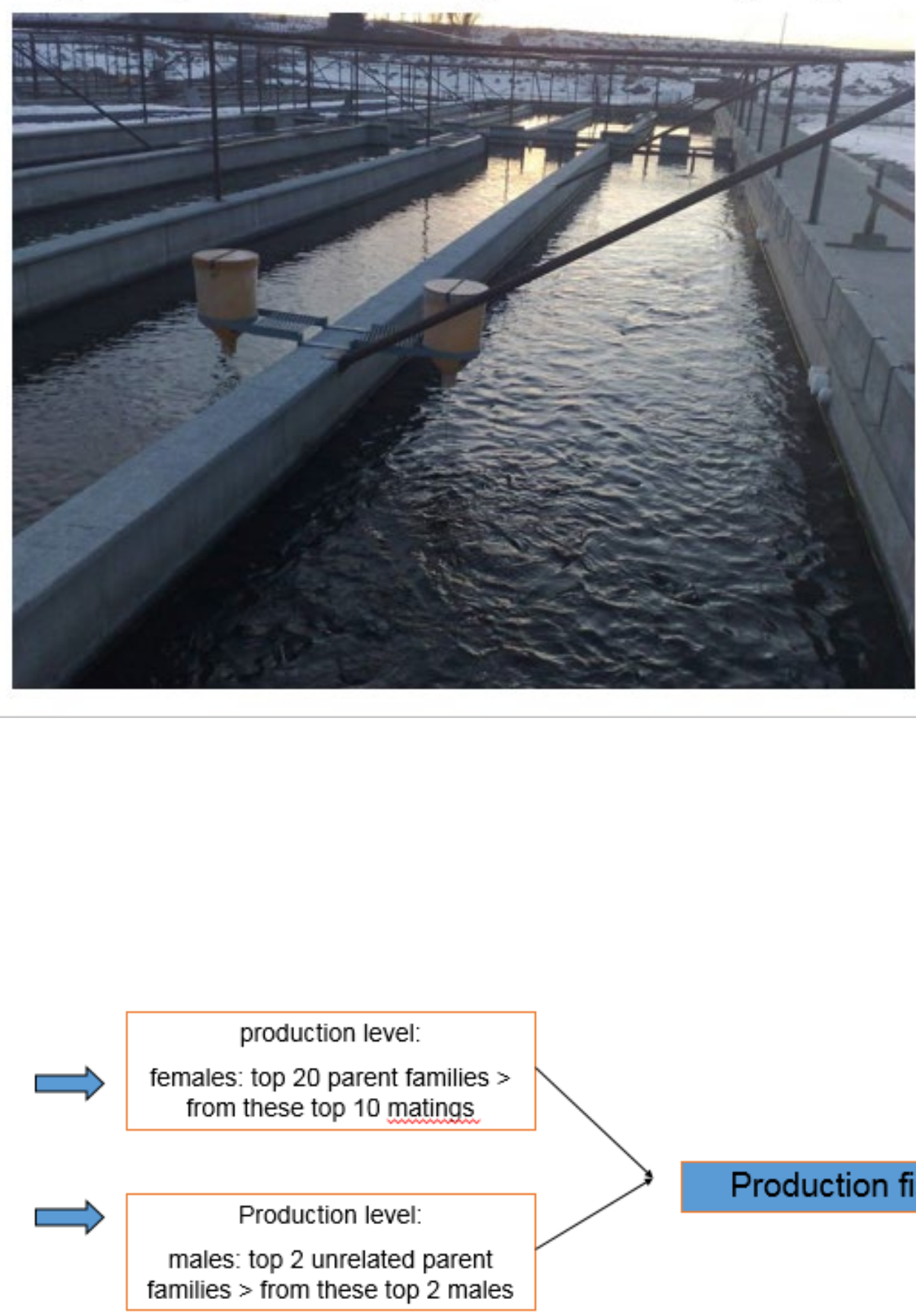

Production fish: $2-3 \mathrm{~kg}$ 


\section{Higher genetic potential by two-stage selection}

- 2500 fish in cold environment

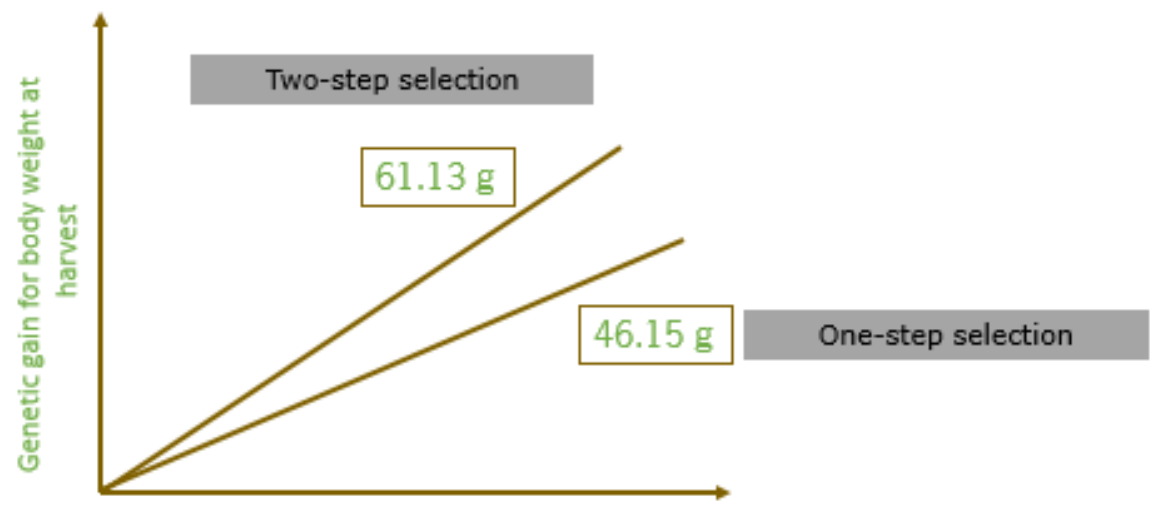

Generation

\section{Diverse environments}

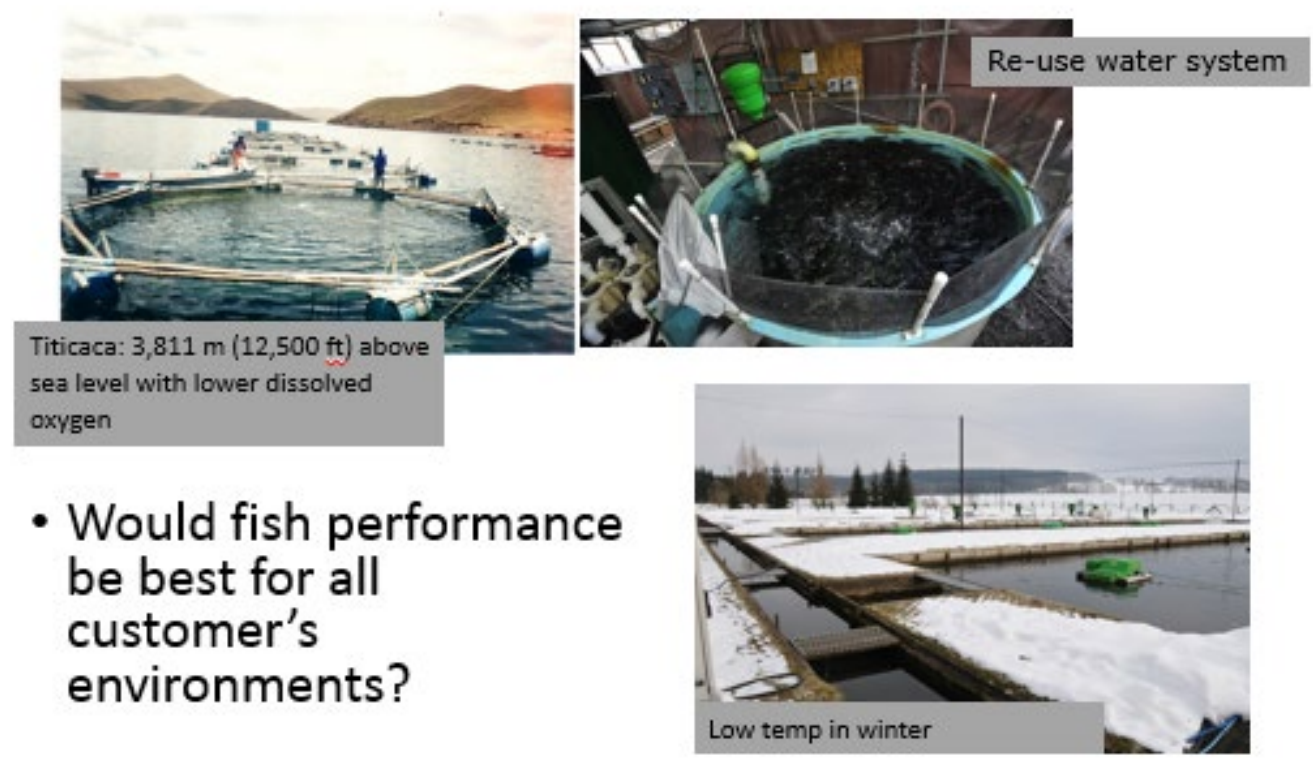




\section{Results for body weight}

- Correlation is the "indicator"

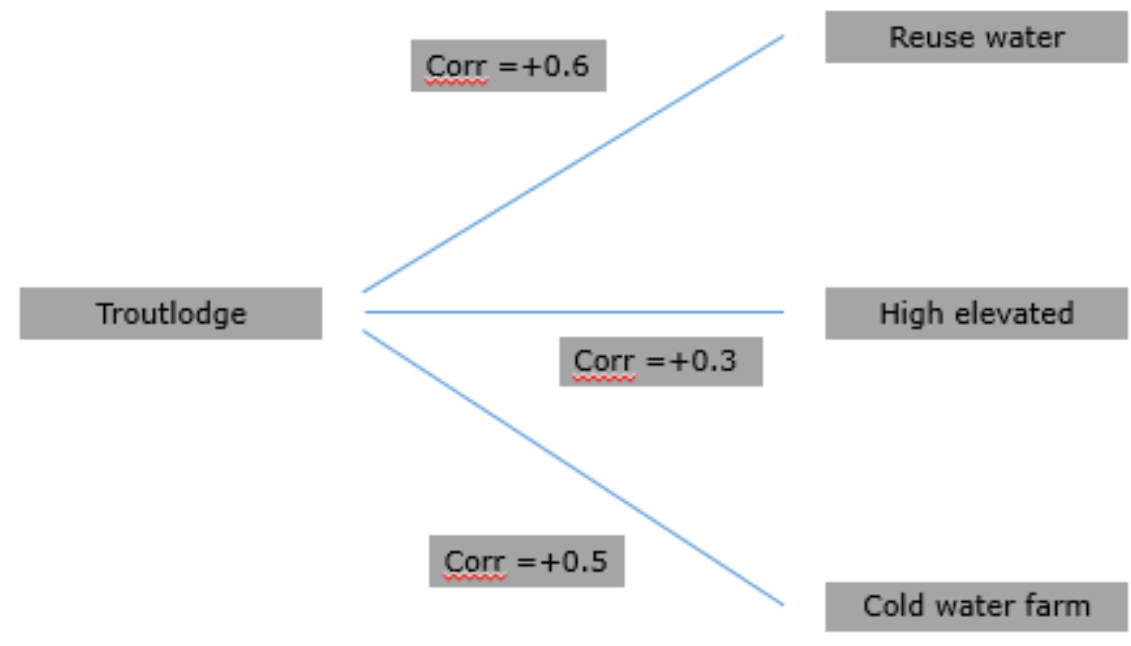

\section{Benefits of selection in trout: Finnish national breeding program}

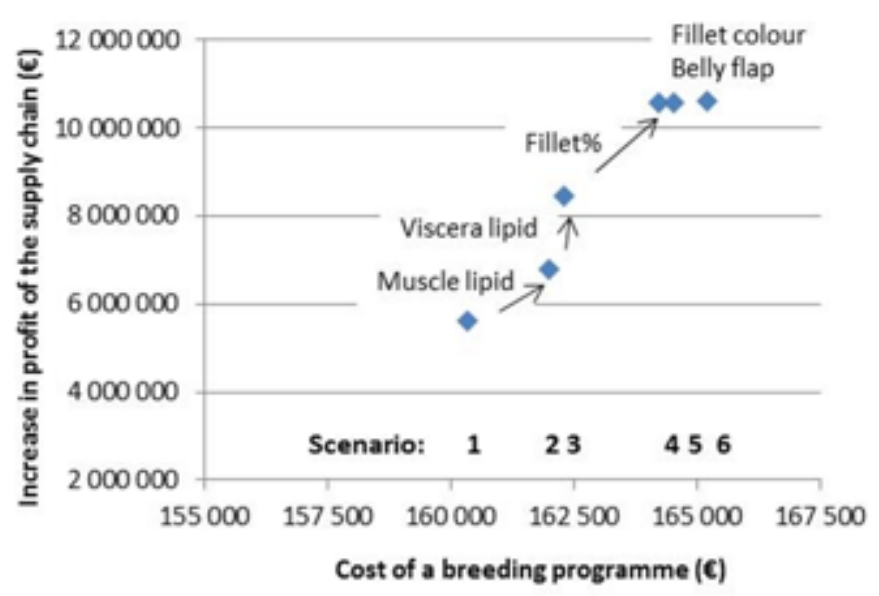

Kause, Kankainen 2018 


\section{Breeding Programs for bass and bream}
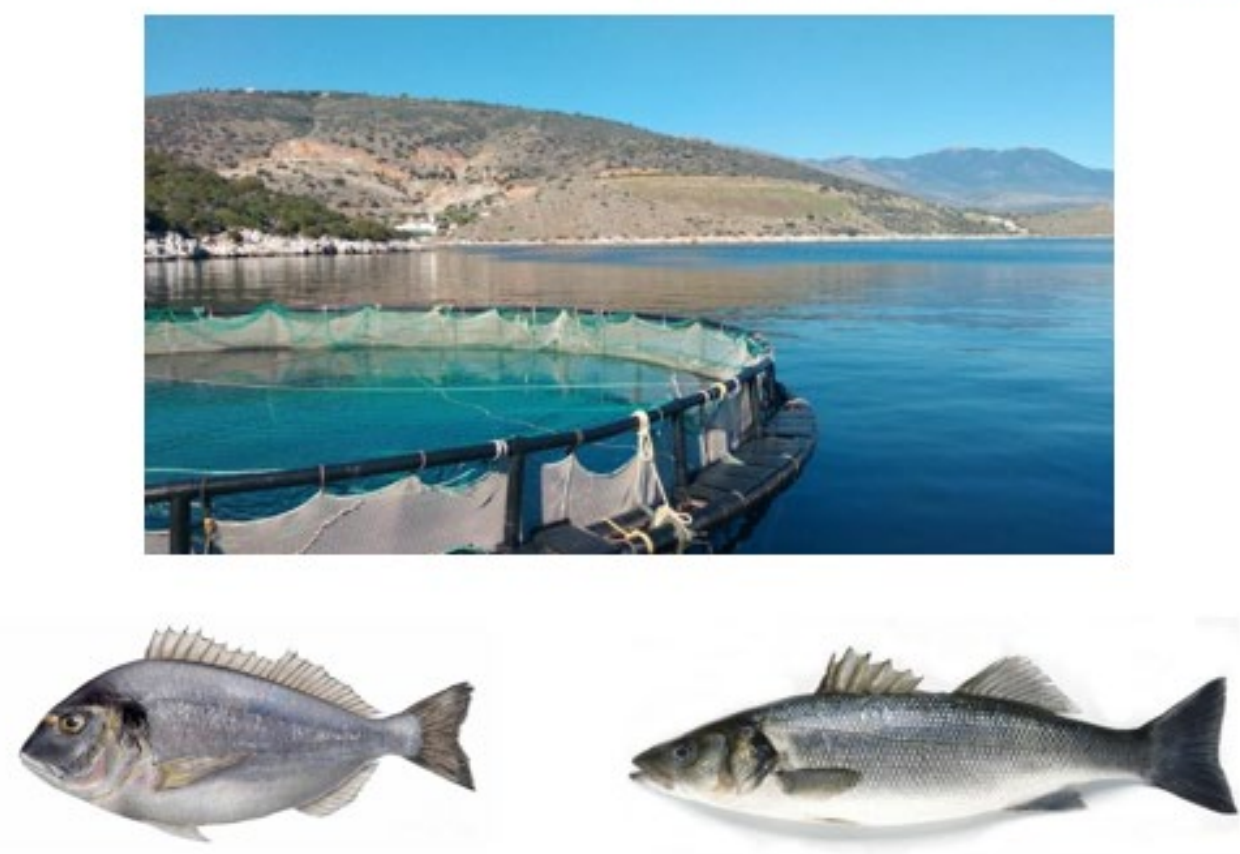

FISHBOOST

\section{The neat level of aquaculiue breabing}

\section{Market share 2012}

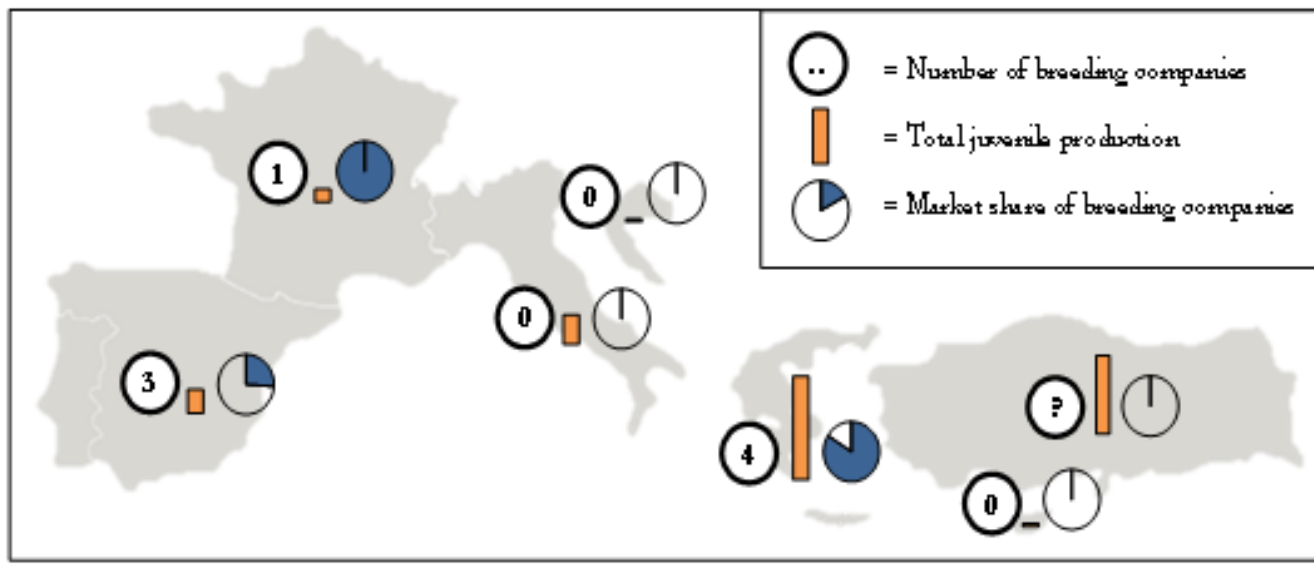

Market share breeding companies: $60-66 \%$

$\mathrm{FISHBOSOST}_{2}$ 


\section{Market share 2012}
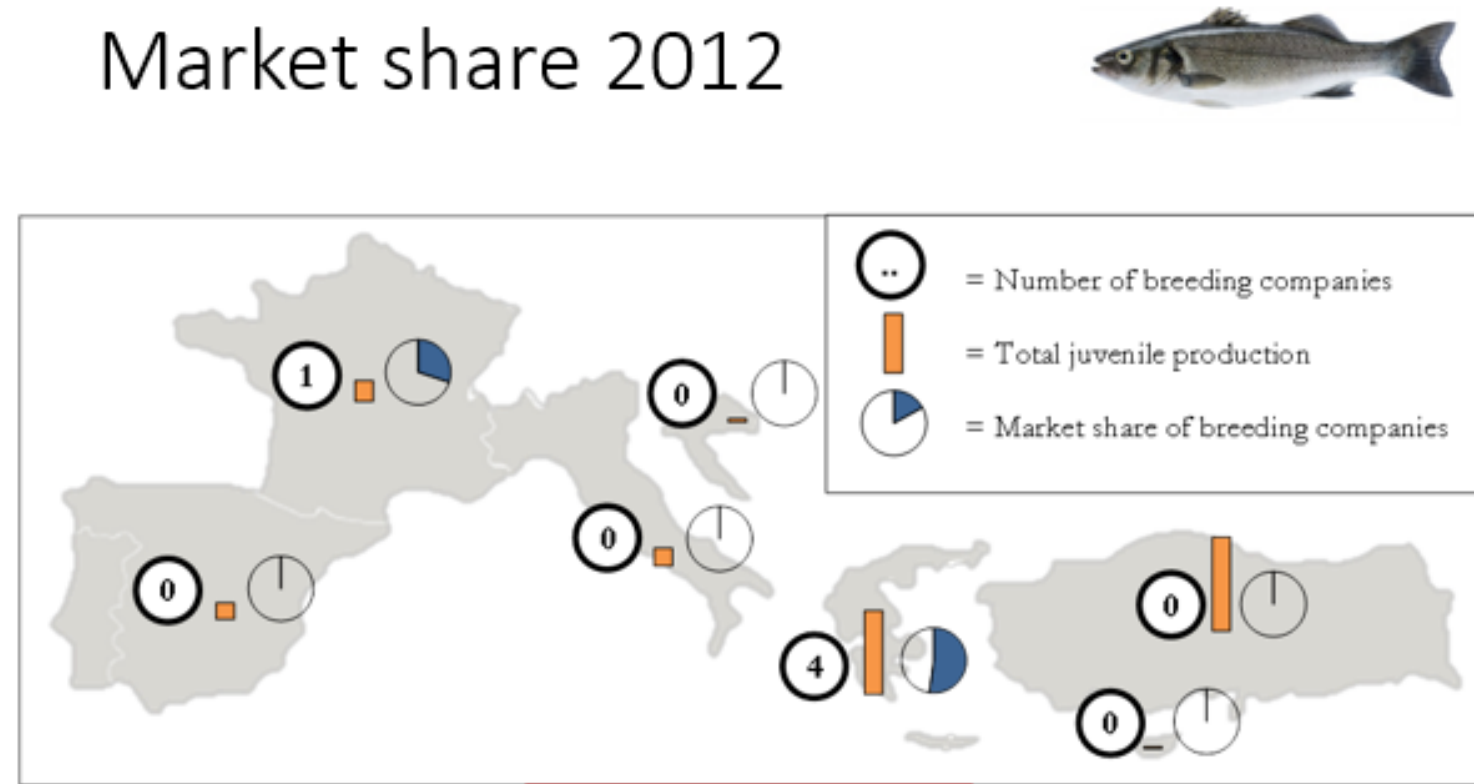

Market share

breeding companies:

$43-51 \%$

$\mathrm{FISHBCOST_{3 }}$

\section{Sea bass production cycle}

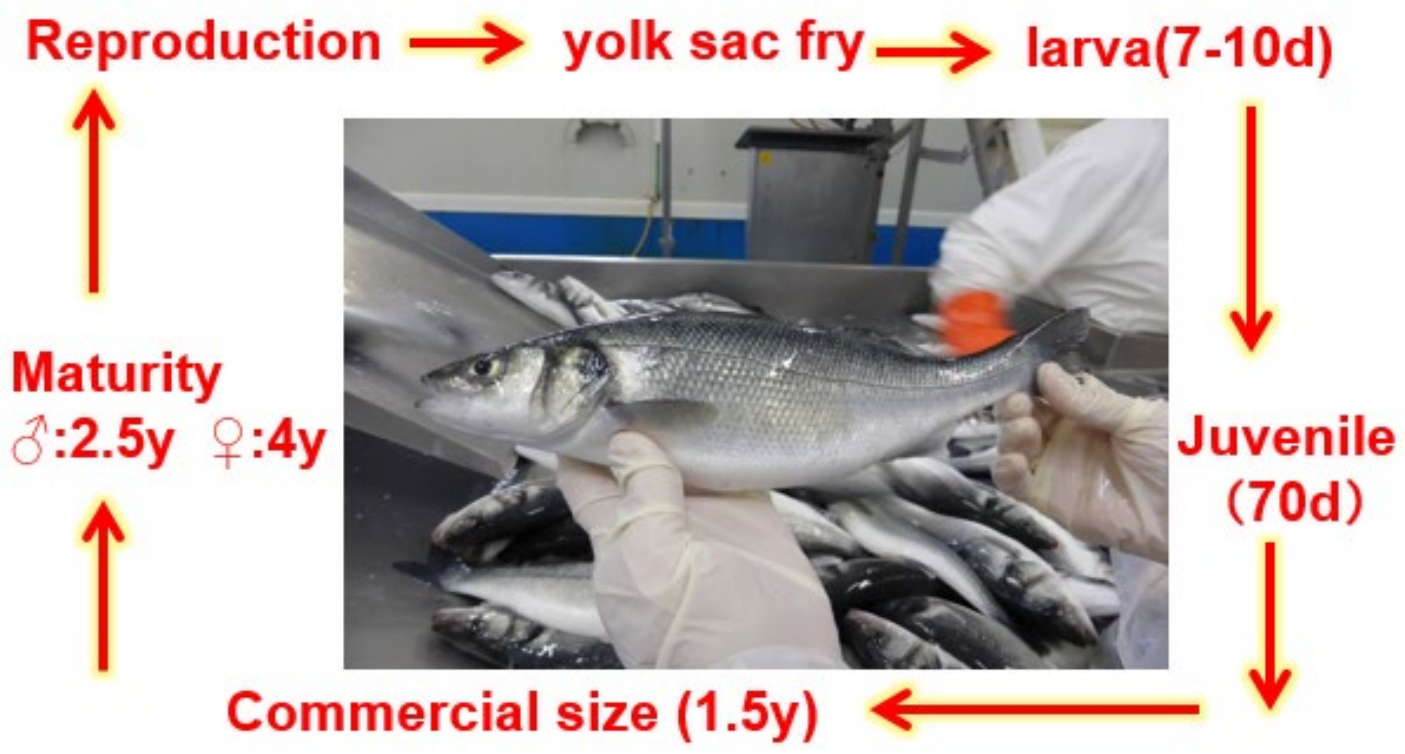




\section{Mass Spawning - Seabass and seabream}

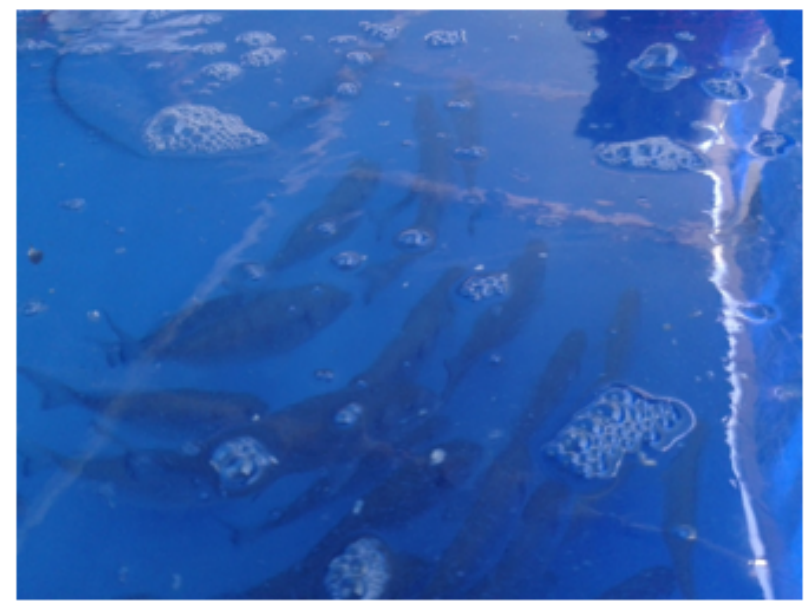

30 / 40 fish per tank

Priming with slow release pellet GNRH to synchronize spawning

Continues egg collection over multiple days

\section{Large $\mathrm{nr}$ of broodstock tanks to produce multiple batches /vear}

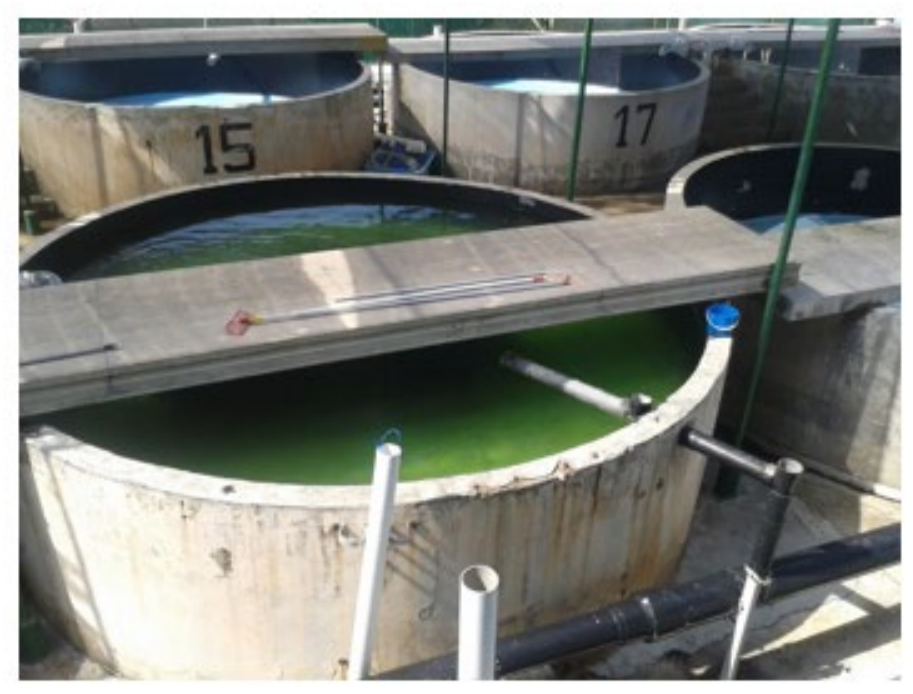




\section{Parent contributions}

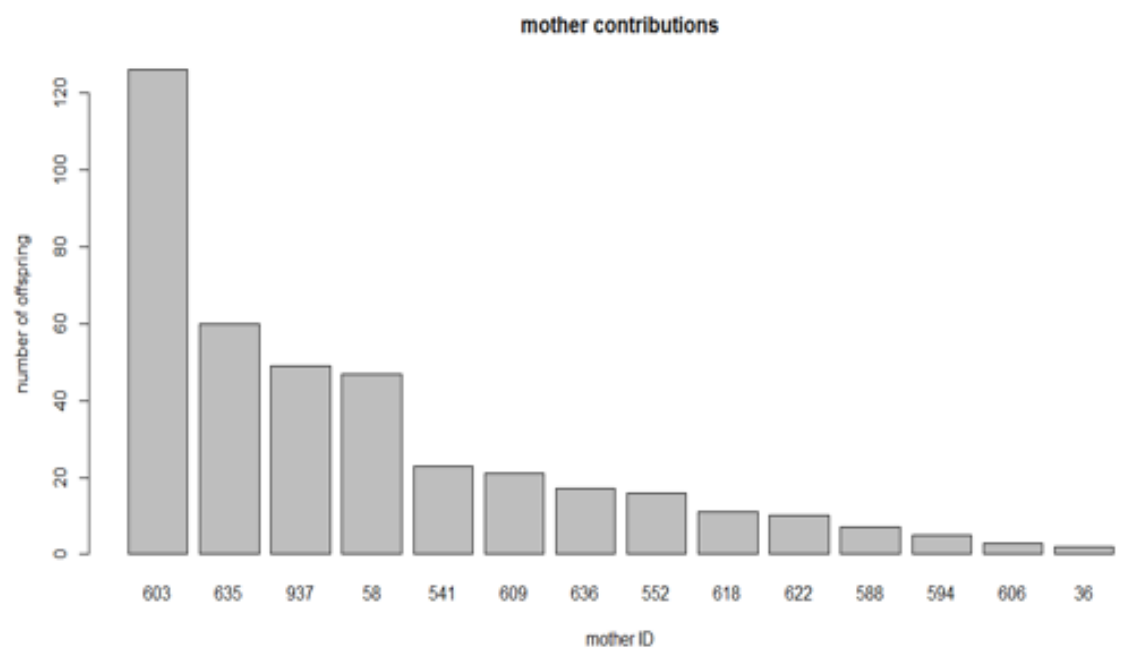

FS families

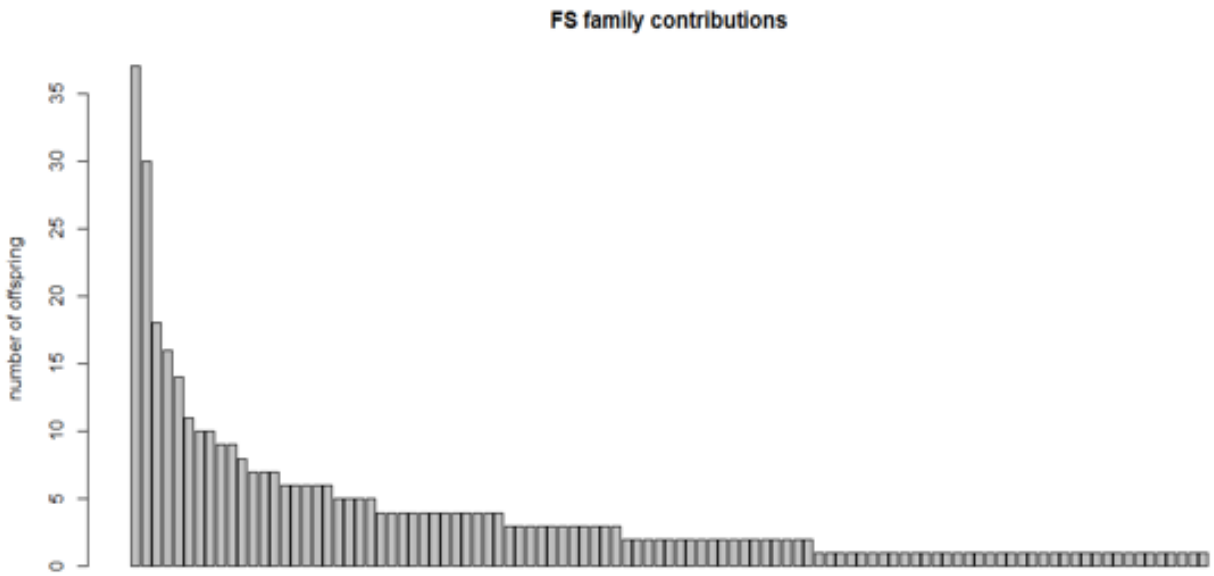




\section{Broodstock mating}

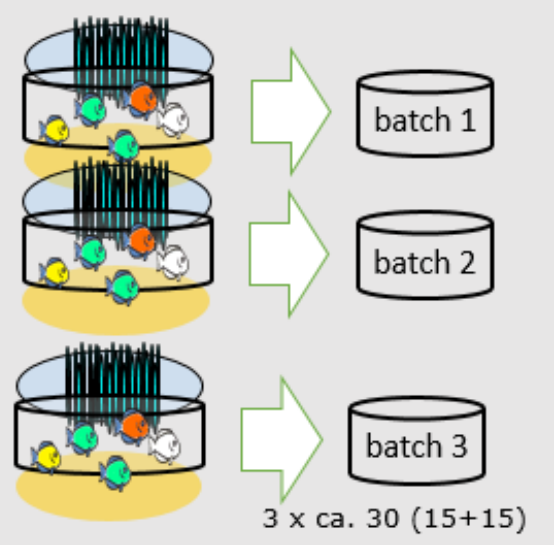

- 3 broodstocks: batches of eggs collected from 2 days incubated separately per broodstock.

- Selection candidates treated normally, but kept separately.

- After this: normal production management of broodstocks can continue

- Batches should be of the same age!!

\section{Larval rearing}
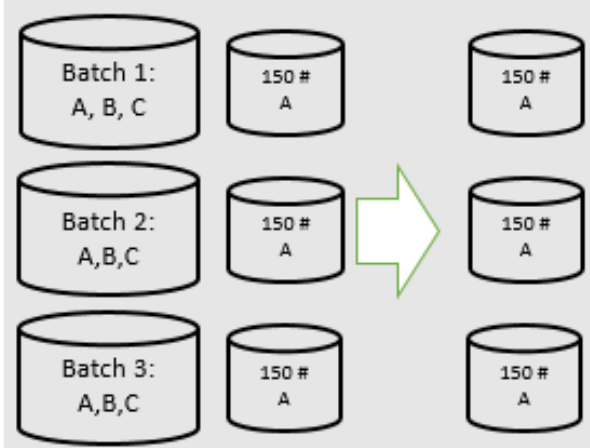

- 150 fish from separate batches of fry from grade A kept separate in small cage

- Rearing to 8-10 g

- Protocol

$$
0-2 \mathrm{~g} \quad 2 \mathrm{~g} \quad 8-10 \mathrm{~g}
$$




\section{Tagging and stocking}

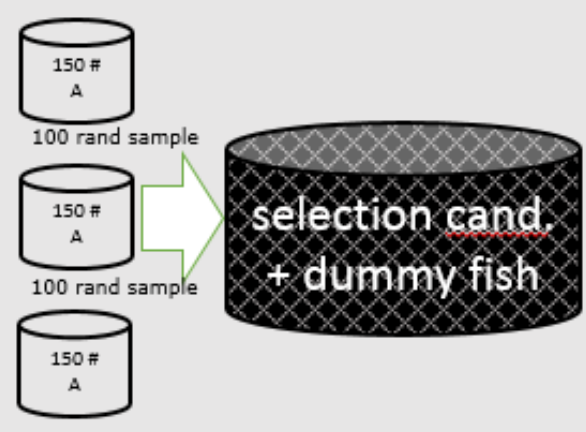

100 rand sample

- Tagging + weighing + photo + record original BS (data recording) of 100 randomly sampled selection candidates

- stocking in $5 \times 2.5 \times 5$ cage $62.5 \mathrm{~m}^{3}$

- Adding of approximately 1700 untagged dummy fish to create commercial density.

- Final number $=300+1700=2000$ fish $/$ cage

\section{ongrowing}

- Grow out

- "normal" production management approx. 18 months

- Target average weight $400 \mathrm{~g}$

- Feeding according to feeding table, well dispersed feeding

- No grading 


\section{Trait recording}

- Pictures - shape!

- Weight

- Thermal growth coefficient

- Fat-\%

- Correlations with Liver fat - fillet yield

\section{Measuring fat}

- Measuring fat with Distell fat meter

- 1181 animals

- 8 different measuring points
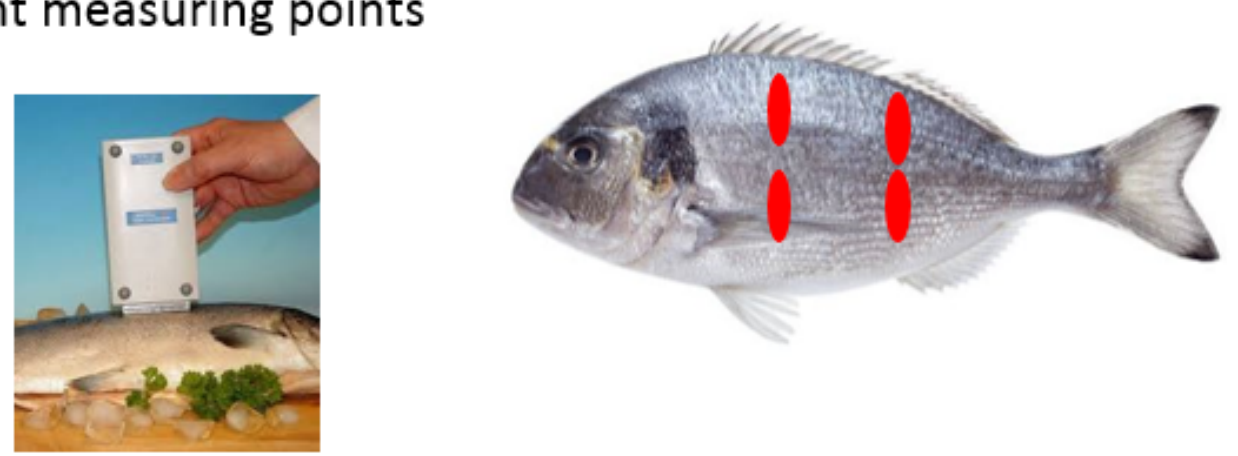


\section{Taking pictures}

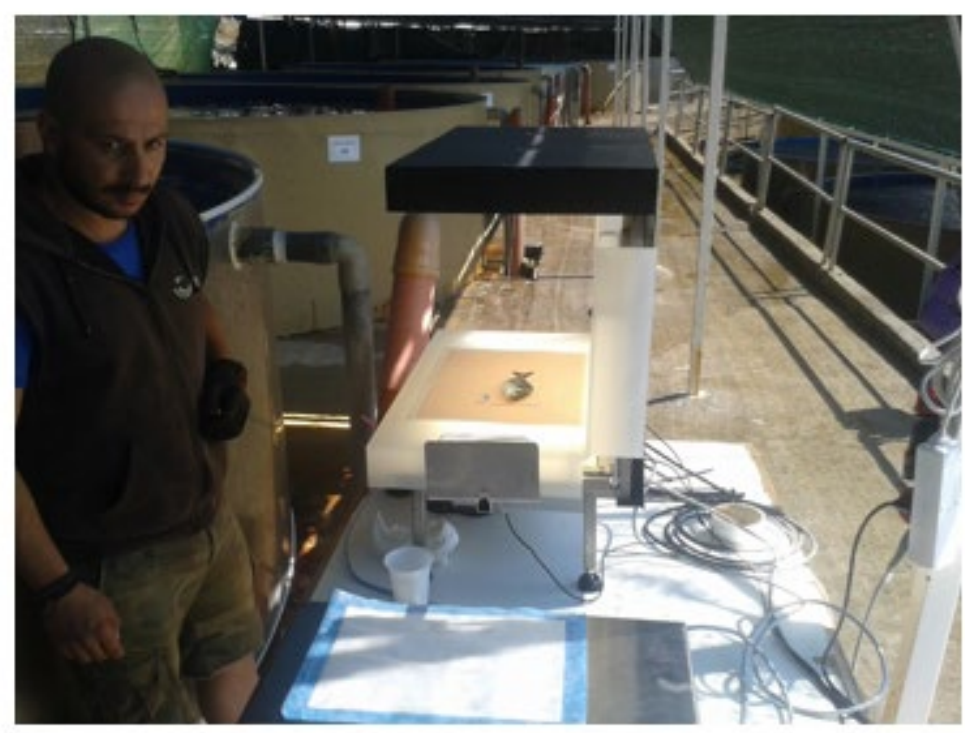

Measuring shape
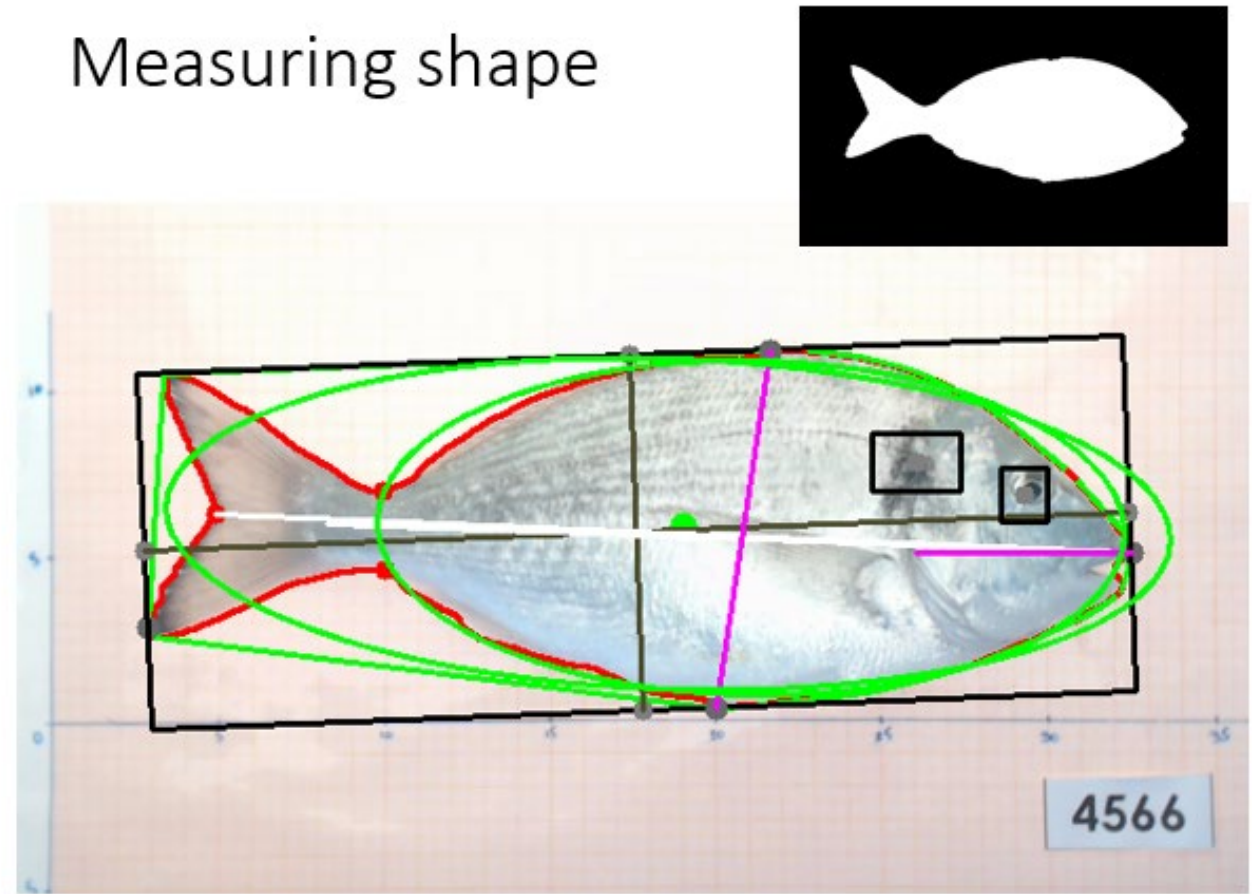


\section{Genetics of fish growth in Greece v.}

Spain

- Growth performance

Project : Genotype by Environment

Interaction in sea bream

- Collect phenotypes

- Estimate correlations

Growth

Fillet Yield

Quality

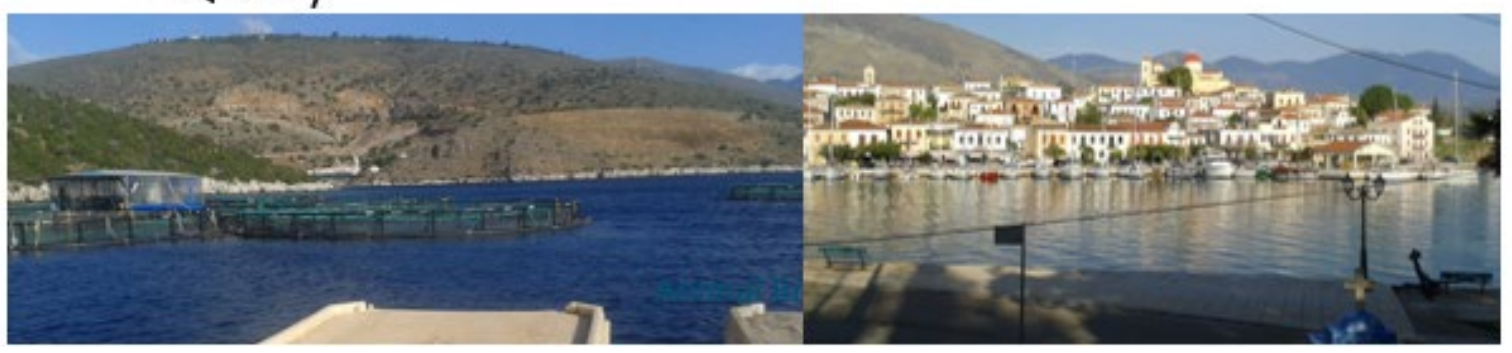




\section{Breeding Programs for Tilapia}

\section{In this presentation}

- Current status of tilapia selective breeding

- Defining the breeding goal - economic considerations

- Solving the yield gap - production efficiency
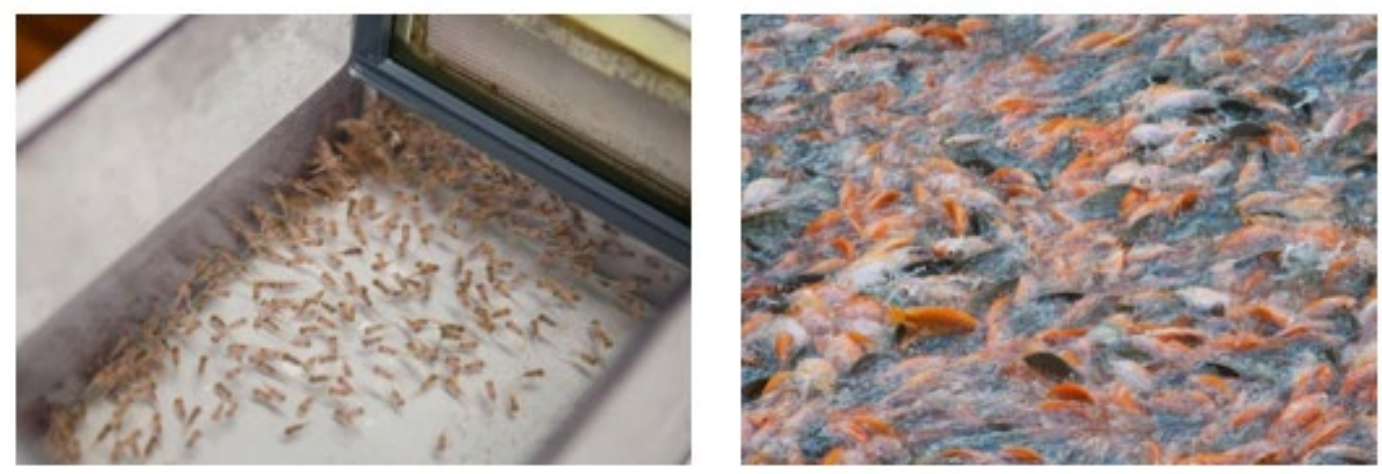


\section{Nile tilapia: a fast growing herbivore}

In 2012 the FAO listed world Nile Tilapia production at 3,5 million mt, valued at $\$ 5$ billion USD.

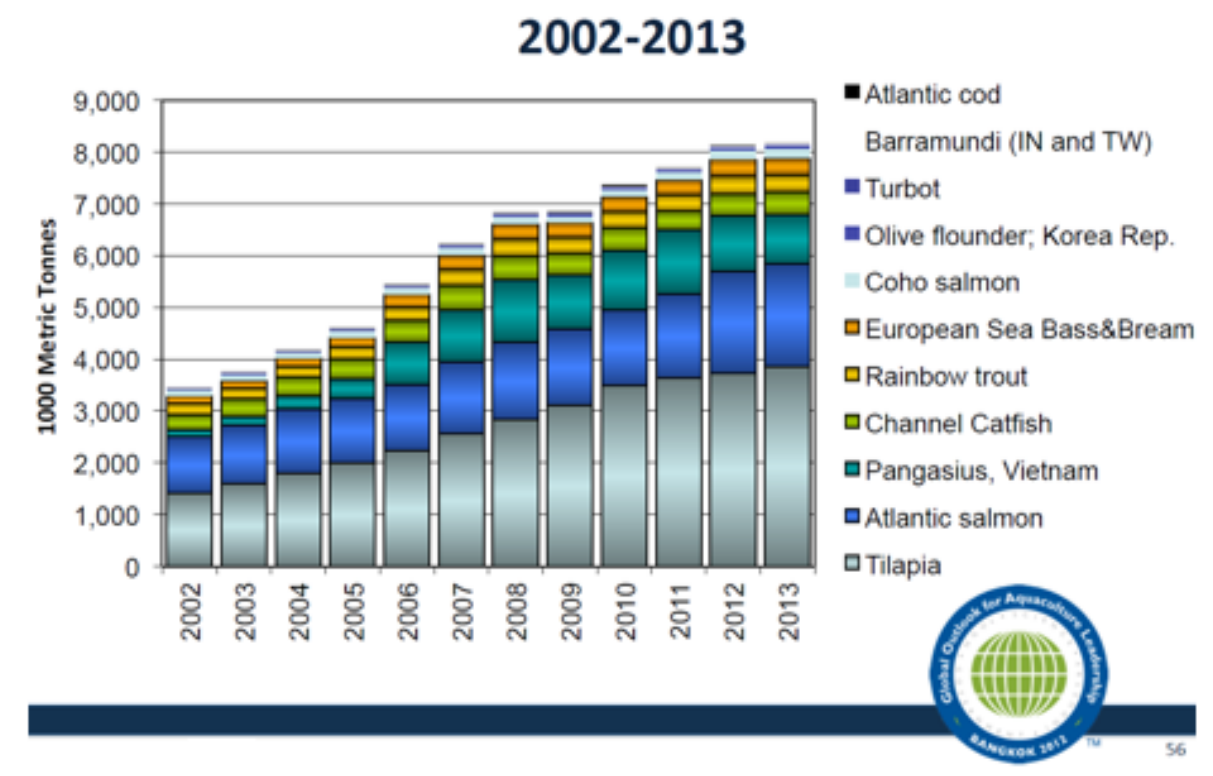

\section{Estimated mortalities(\%) from case studies}

\begin{tabular}{|l|c|}
\hline Egypt & $25-60$ \\
\hline Thailand & \\
\hline Ponds & $35-50$ \\
\hline Cages & $35-40$ \\
\hline Bangladesh & $\mathbf{3 0}$ \\
\hline Philippines & $\mathbf{4 0}$ \\
\hline
\end{tabular}


GIFT G13

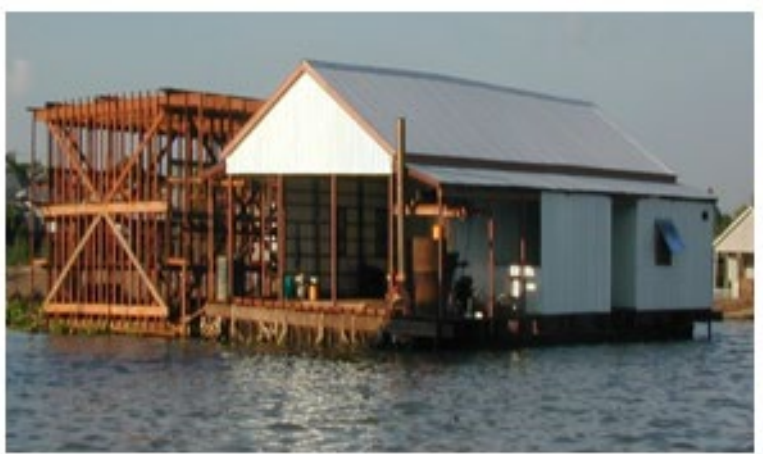

$35 \%$ protein $->3.8$

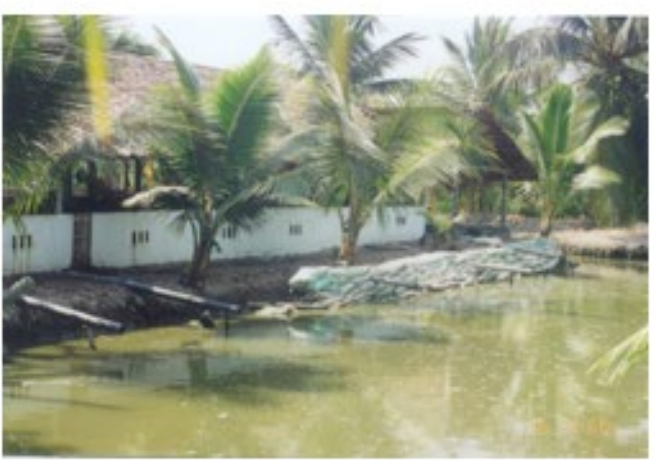

Natural feed $->2.2$

\section{Mortality and production efficiency}

$P E=\underline{\text { Total net weight gain at Harvest }}$

Total feed used or procured

Net harvest $=$ remainder after total mortality

Total mortality (weight) $=$ Total biomass loss from disease + handling + grading + escapes + predation over production cycle. 


\section{Overall Performance of Diets - PE}

\begin{tabular}{|c|c|c|c|c|c|c|c|}
\hline & China & Thailand & Philippines & \multicolumn{2}{|c|}{ Egypt } & \multicolumn{2}{|c|}{ Ghana } \\
\cline { 2 - 8 } & & & & & \multicolumn{2}{|c|}{} \\
\hline System & Pond & Pond & Cages/pond & Cage & Pond & Cage & Pond \\
\hline $\begin{array}{c}\text { Comm. } \\
\text { Feed }\end{array}$ & 1.69 & $1.4-1.6$ & $1.5-1.7$ & $1.3-1.7$ & $1.4-1.9$ & $1.2-1.4$ & $1.8-2.3$ \\
\hline
\end{tabular}

- Irrespective of country or system PE in similar range

- Significant effort still devoted to nutritional quality/ formulations/substitutions

- What about genetics?

\section{Breeding programs for Tilapia (all species)}

\begin{tabular}{lccc} 
& $\begin{array}{c}\text { All } \\
\text { programs }\end{array}$ & Family selection \\
\cline { 3 - 4 } China & Private & Public \\
Thailand & 16 & 5 & 2 \\
Egypt & 10 & $2(3)$ & \\
Mexico & 1 & & 1 \\
Brazil & 9 & 3 & \\
Peru & 6 & 5 & 1 \\
Colombia & 2 & 2 & \\
Ecuador & 6 & 1 & \\
\hline Total & 2 & 1 & \\
\multicolumn{5}{l}{} & $\mathbf{5 2}$ & $\mathbf{1 9}$ & 4 \\
& Source: www.inocap.no/year 2014
\end{tabular}




\section{GIFT - a brief history}

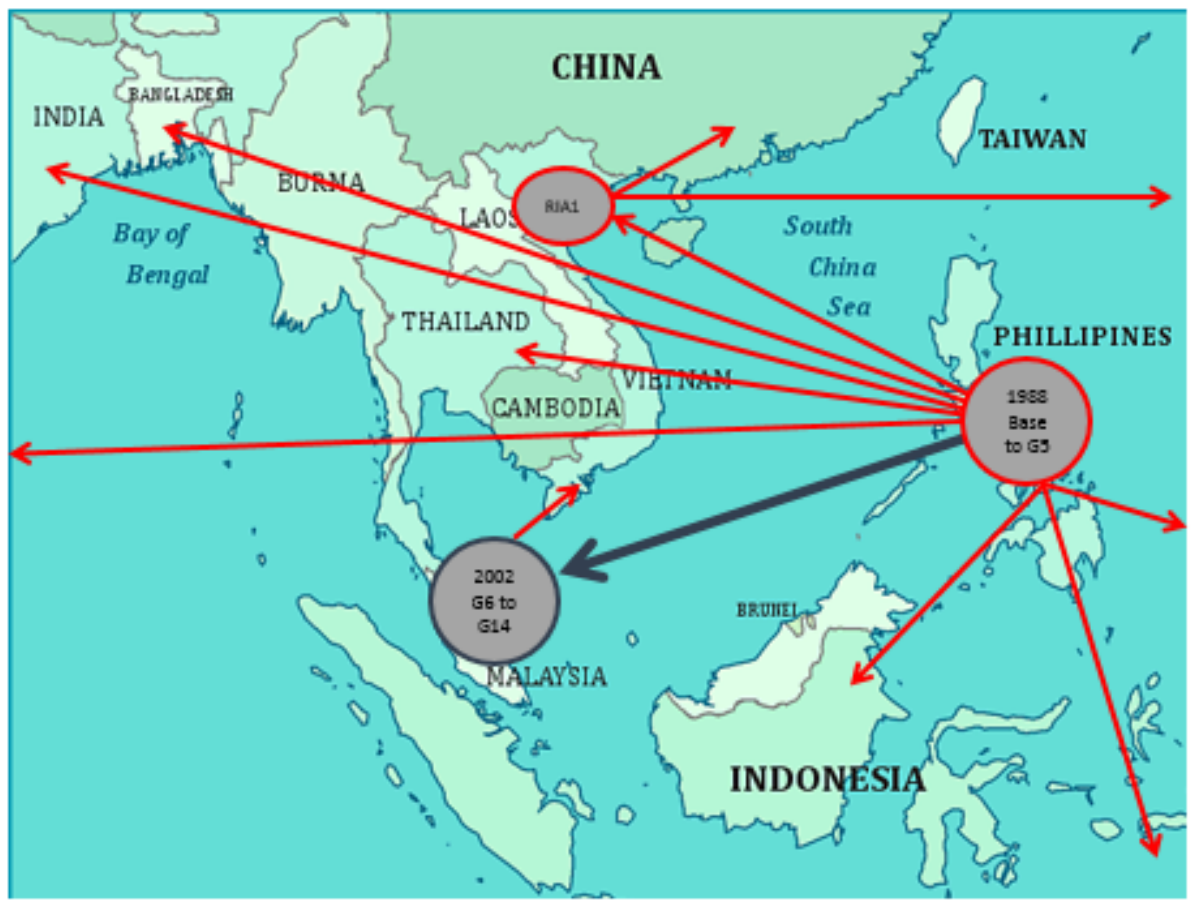

Examples of commercial strains with ancient GIFT 'heritage'

- Genomar supreme tilapia

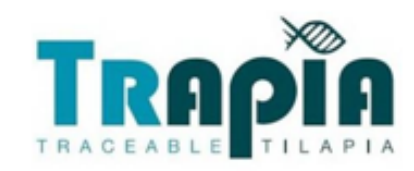

- Spring genetics

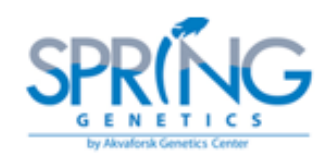

- ProGift Hainan

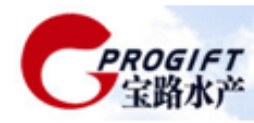




\section{Conventional BLUP scheme: GIFT}

- Hapa/GIFT system

- Mating 1 male $\times 2$ females

- Produce 100 full and half sib families

- Select 40 fish/family for tagging and growing out
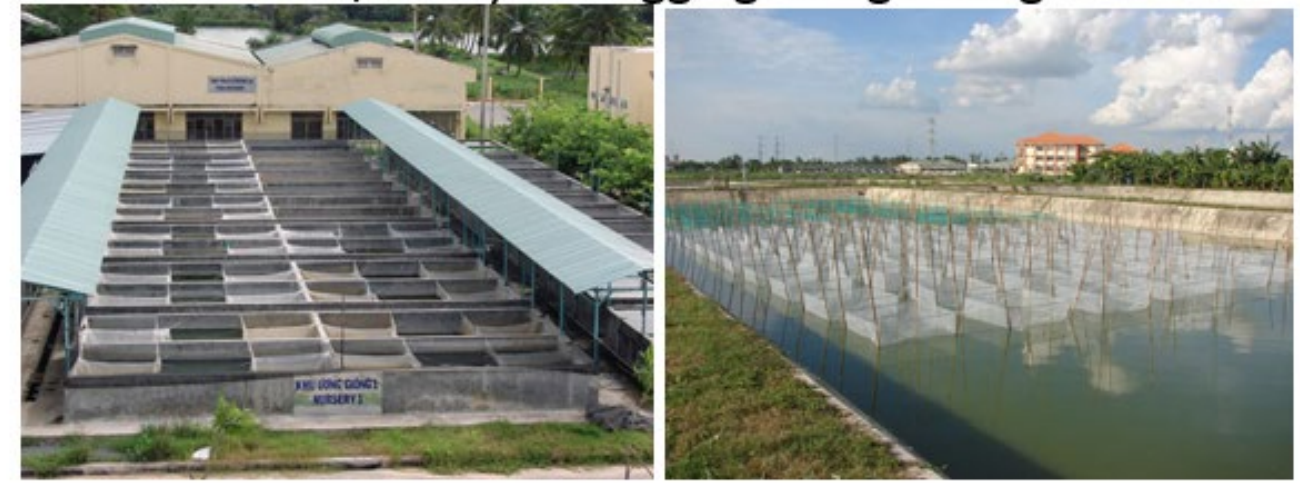

\section{Growing out}

- 4 ponds, $1,000 \mathrm{~m}^{2}$ each

- In each pond:

- $1 / 4$ offspring of the BLUP scheme

- Advantages:

- there is no pond effect

- There are 4 replicates of BLUP

- Adjust for pond effect for BLUP 


\section{Time frame of mating, spawning, growing out}

Table 1

Stocking age, grow-out time, number of tilapia at stocking and at harvest, and survival rate at harvest in cage, nucleus, and VAC.

\begin{tabular}{|c|c|c|c|c|c|}
\hline \multirow[t]{2}{*}{ Environment } & \multirow[t]{2}{*}{ Stocking age } & \multirow{2}{*}{$\begin{array}{l}\text { Grow-out time } \\
\text { (days) }\end{array}$} & \multicolumn{2}{|l|}{ \# of fish } & \multirow{2}{*}{$\begin{array}{l}\text { Survival } \\
\text { (\%) }\end{array}$} \\
\hline & & & Stocking & Harvest & \\
\hline Cage & $63-208$ & $140-173$ & & & \\
\hline Cage 1 & & & 1164 & 340 & 29 \\
\hline Cage 2 & & & 1514 & 418 & 28 \\
\hline Nucleus & $77-194$ & $140-176$ & 3775 & 1946 & 52 \\
\hline $\mathrm{VAC}^{\mathrm{a}}$ & $71-183$ & $163-195$ & 1118 & 760 & 68 \\
\hline
\end{tabular}

\section{Reduction in grow-out time due to selection (days to $1 \mathrm{~kg}$ )}

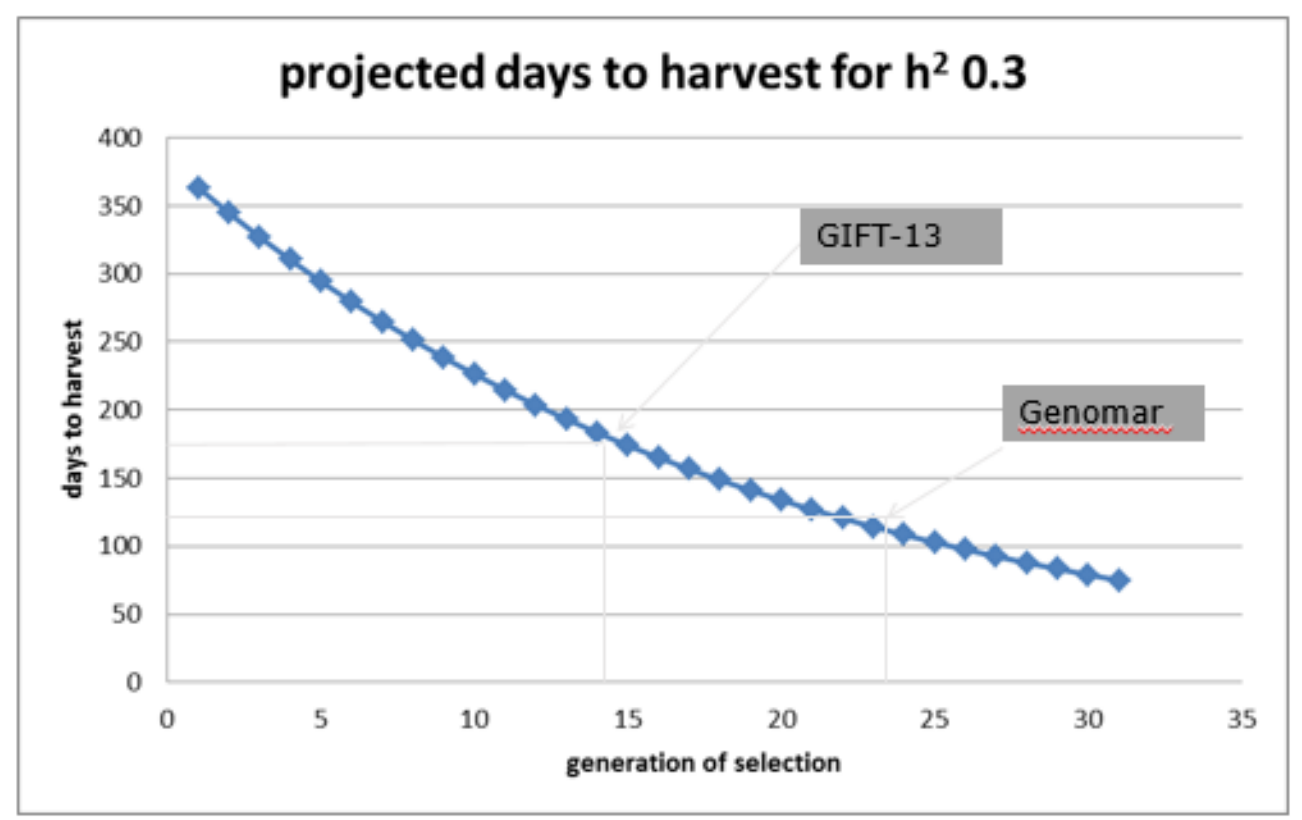




\section{A comparison across strains}

\begin{tabular}{|lcl|}
\hline environment & TGC & Strain \\
\hline Pond & 1.56 & Sagana, Base Pop+1, Kenya; \\
\hline Cage & 5.05 & \\
Pond & 4.67 & ProGIFT, G12, China \\
\hline Pond & 3.11 & \\
River cage & 3.85 & GIFT G13, Vietnam \\
\hline RAS, G6 & 4.46 & Dutch RAS (Base AIT x GIFT) \\
\hline
\end{tabular}

\section{Correlated responses to selection}

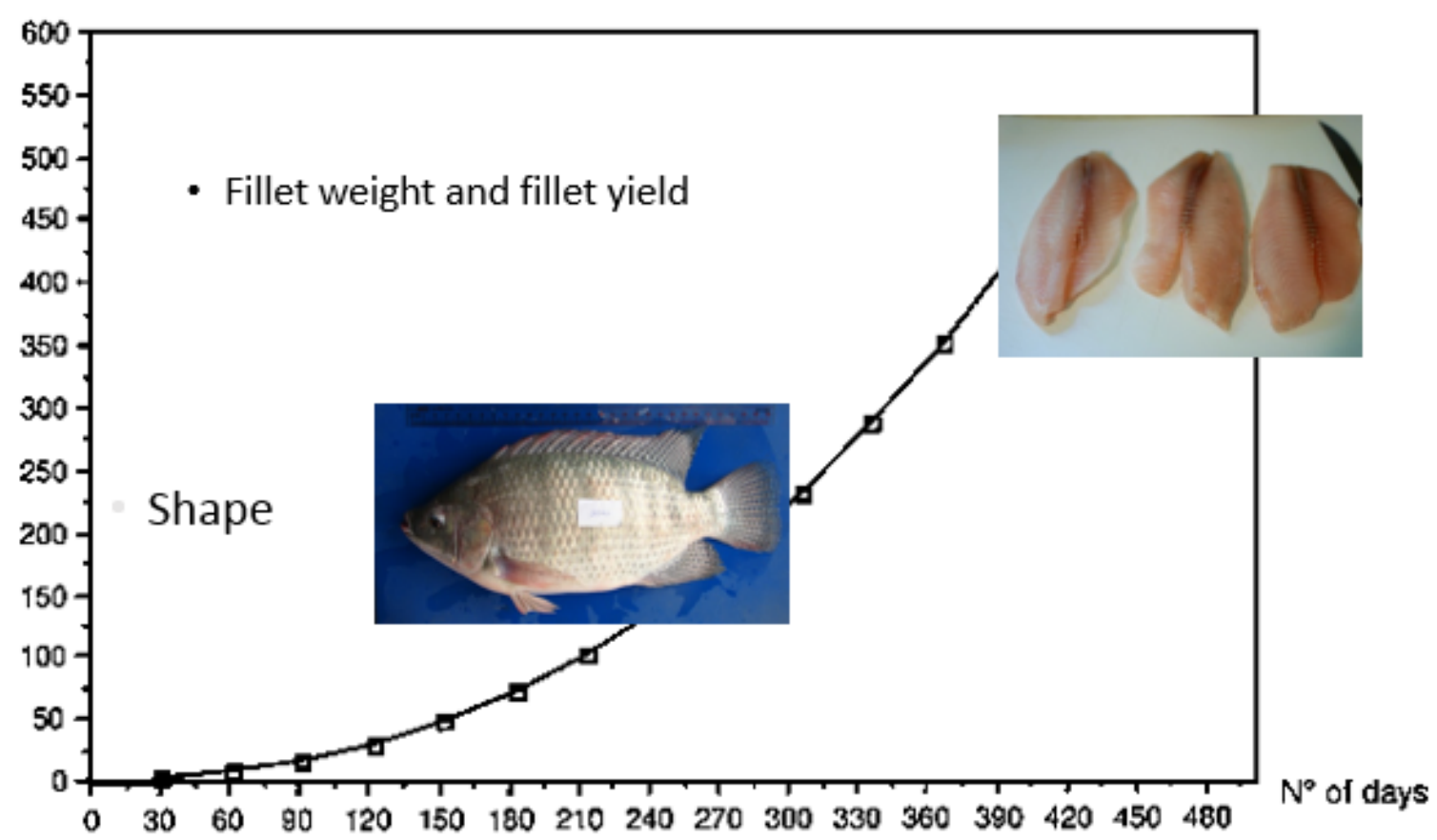




\section{Fillet weight and Fillet yield}

\begin{tabular}{|c|c|c|c|c|c|}
\hline \multicolumn{2}{|c|}{ Fillet Weight } & \multicolumn{2}{|l|}{ Fillet-\% } & \multirow[t]{2}{*}{$\Delta \mathrm{G} F-\%$} & \multirow[t]{2}{*}{ reference } \\
\hline$h^{2}$ & $\mathrm{r}_{\mathrm{g}} \mathrm{HW}$ & $h^{2}$ & $\mathrm{r}_{\mathrm{g}} \mathrm{HW}$ & & \\
\hline 0.24 & 0.99 & 0.12 & 0.74 & - & Rutten, 2005 \\
\hline 0.33 & 0.96 & 0.25 & 0.44 & No reps. & Nguyen, 2010 \\
\hline 0.16 & 0.99 & 0.06 & 0.21 & $\begin{array}{l}0.28 \% \\
\text { units }\end{array}$ & Gierde, 2012 \\
\hline 0.30 & - & $0.17-0.23$ & 0.09 & $\begin{array}{l}0.3 \% \\
\text { units }\end{array}$ & Thodesen, 2012 \\
\hline
\end{tabular}

selection for harvest weight will increase fillet yield by correlated response

\section{Shape and ellipticity}

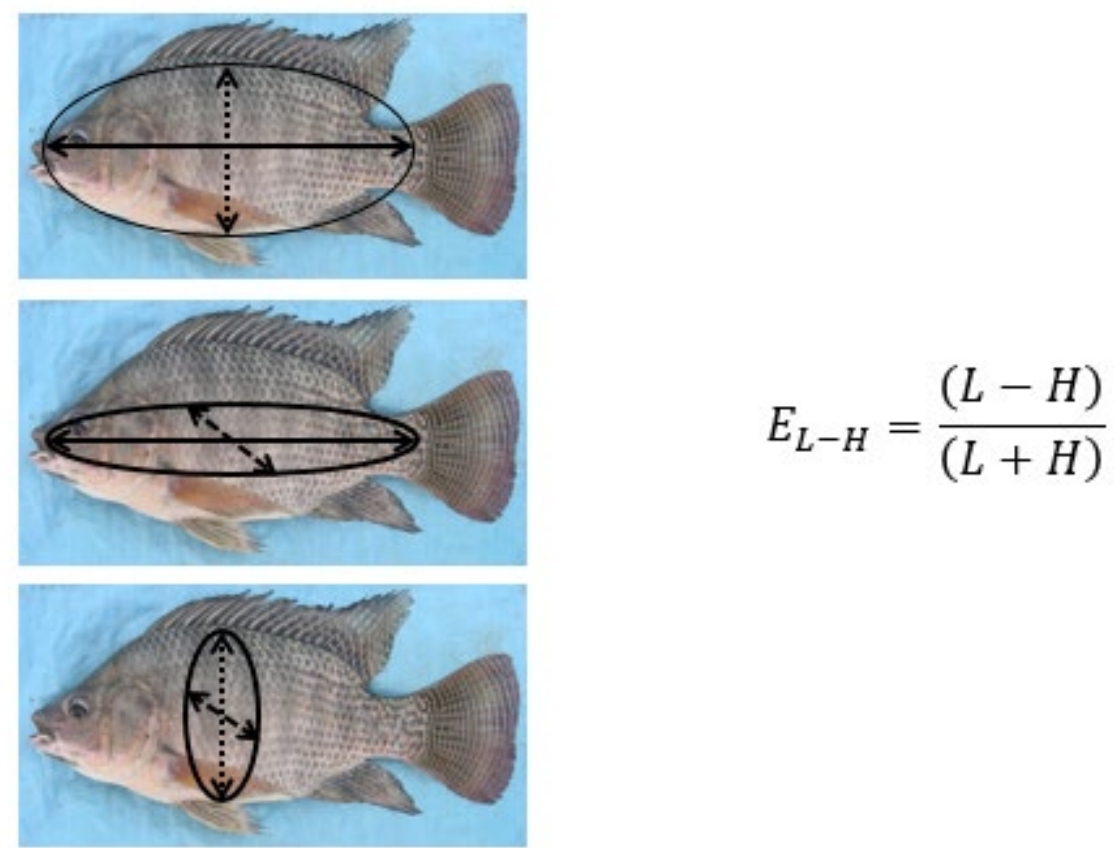




\section{Shape and selection for growth}

- Heavier fish are more round,

- Fish selected for high growth rate become more round \& thicker
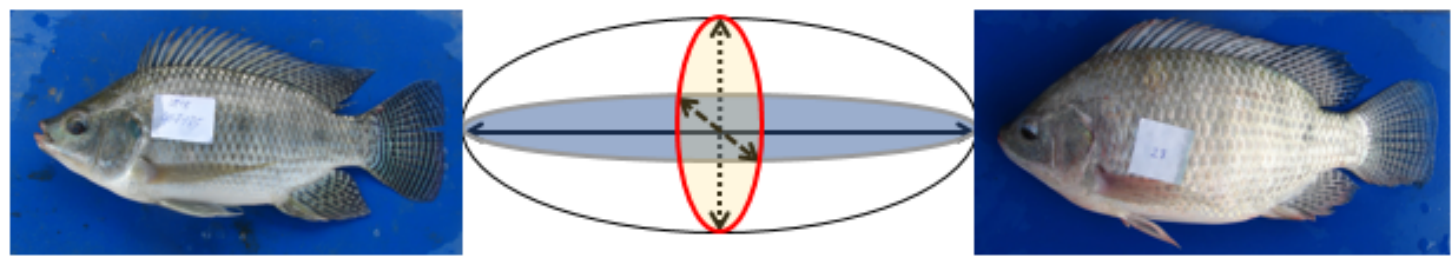

improved breeding scheme

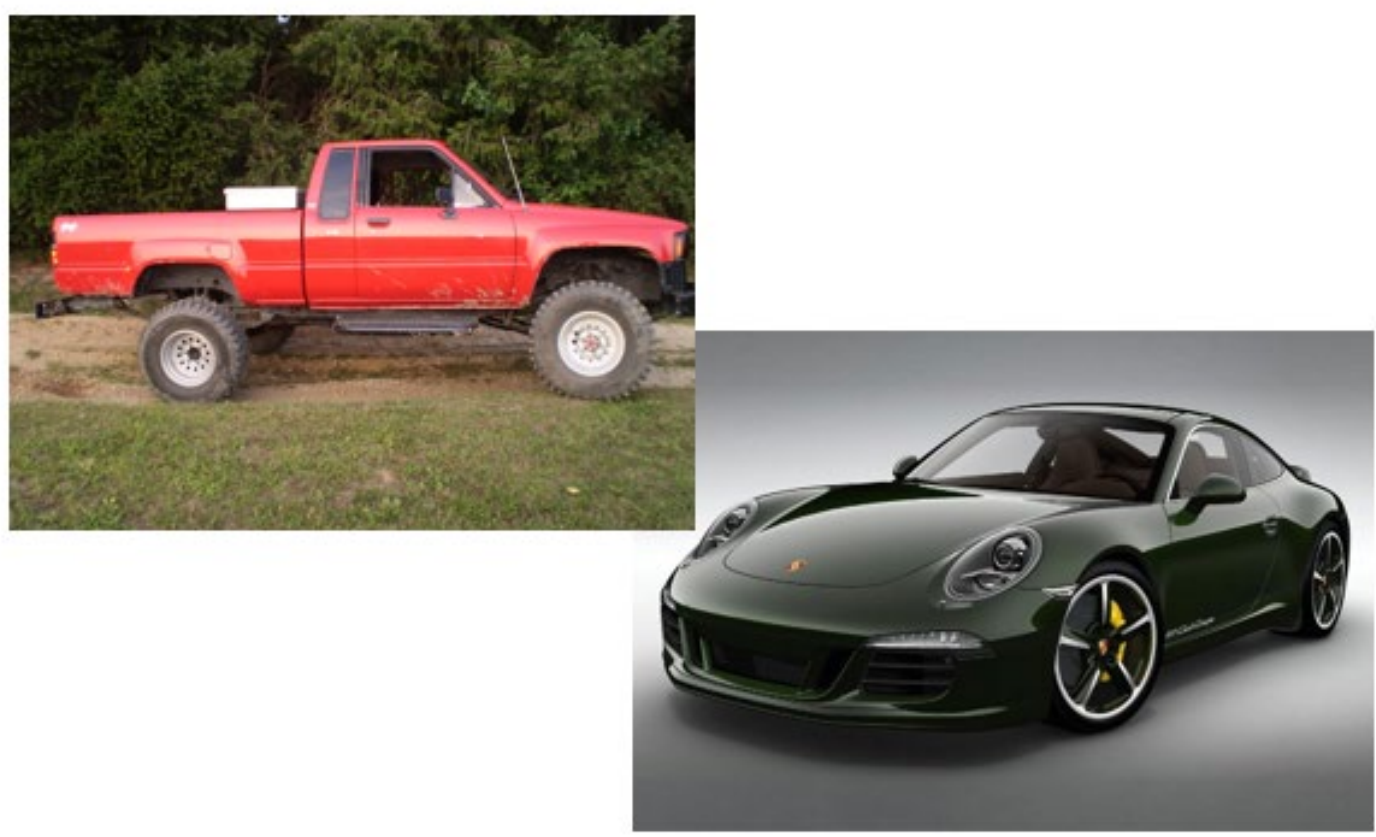




\section{Future directions: the breeding goal}

- Robustness (survival)

\section{porsche}

\section{toyota}

- FCR

- Cold tolerance

- Disease resistance

- Carcass quality traits

- Reproductive performance

- Late maturation

no

yes

no

yes

yes

yes

no

\section{Tilapia breeding program}

- Farm group with ongrowing and fattening facilities.

- Production: 1200 tonnes

- Market: export of whole fresh fish and fillets

- Concerns:

- How to make a base population

- How to increase reproduction

- How to improve growth and fillet yield by selection 


\section{Tilapia breeding program: choices made}

- Trait: (age at) harvest weight on farm

- No selection for fillet yield

- Selection on phenotypic (own) performance

- Natural mating in spawning groups

- Rotational mating system to reduce inbreeding

\section{Rotational mating: principle with 4 cohorts}

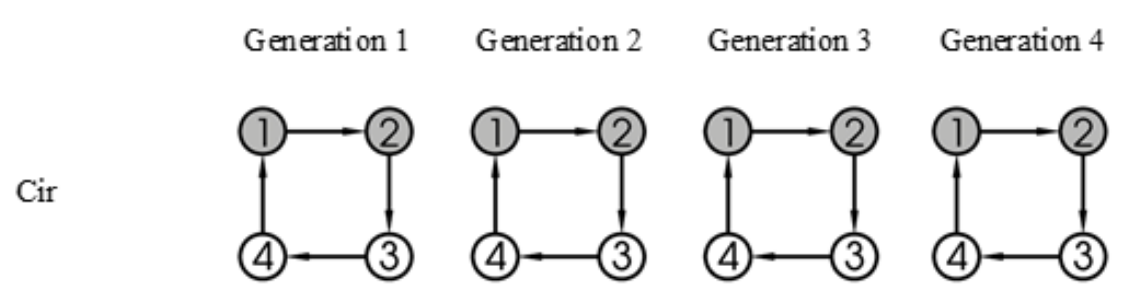




\section{Reproductive performance}

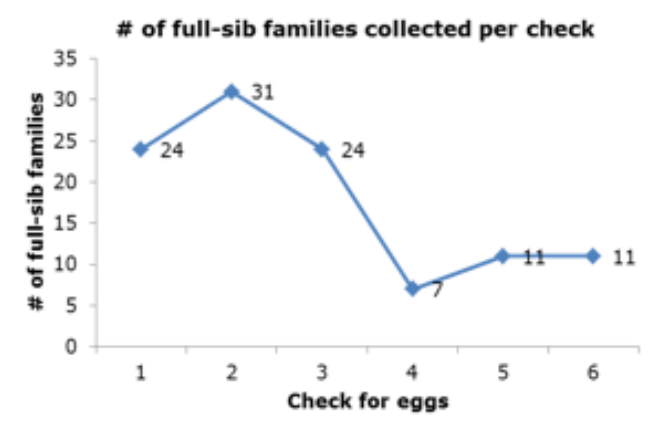

August 15 -sept 20, 2013

Total: 108 Fams produced

26 HS-2 families

10 HS-3 families

1 HS-4 family

Group Mating is fast": 1 male to 5-10 females

Reduction of generation interval by two months: $+20 \%$ gain /vr!

Increase of selection intensity (less fish needed to produce families)

\section{Tilapia breeding program}

- Some results:

- 5 generations of selection

- Harvest weight from 750 gram to > 1000 gram

- Age at harvest from 9 months to 7.5 months

- Correlated response in fillet yield:

$34.6 \%>36.9 \%$ (gen. 4 ) 


\section{Response to selection}

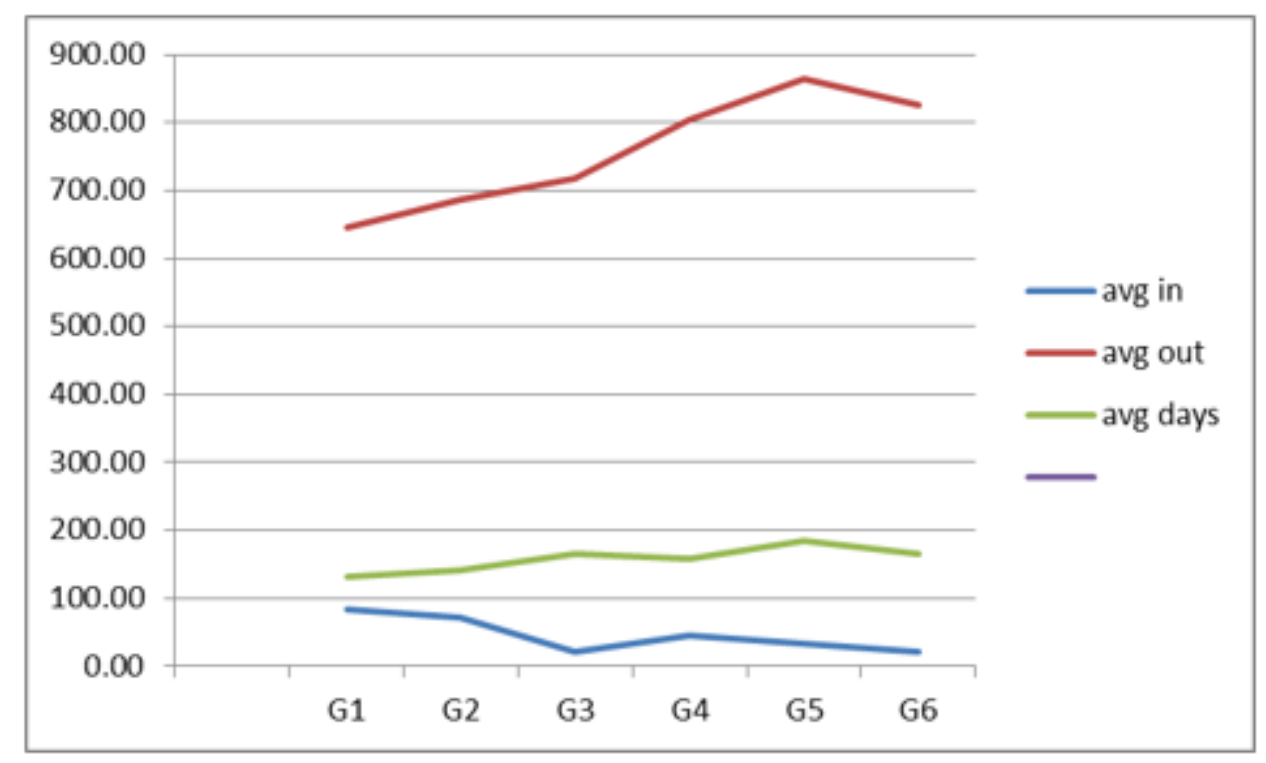

\section{Selection and feed efficiency....}

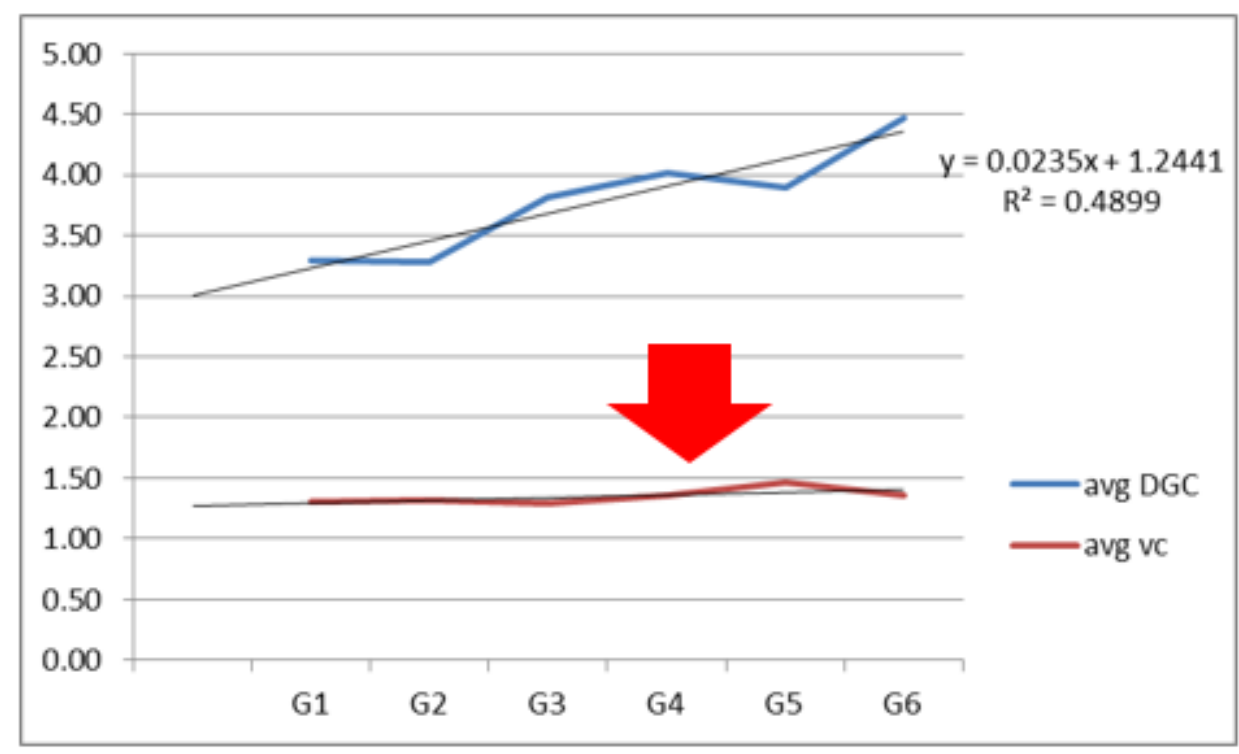

Selection for growth (increased harvest weight) should be accompanied by evaluations on realized FCR 


\section{Cold tolerance}

\section{$h^{2} 0.08 \pm 0.17 ; c^{2} 0.33 \pm 0.10$ (Charo-karisa, 2005}

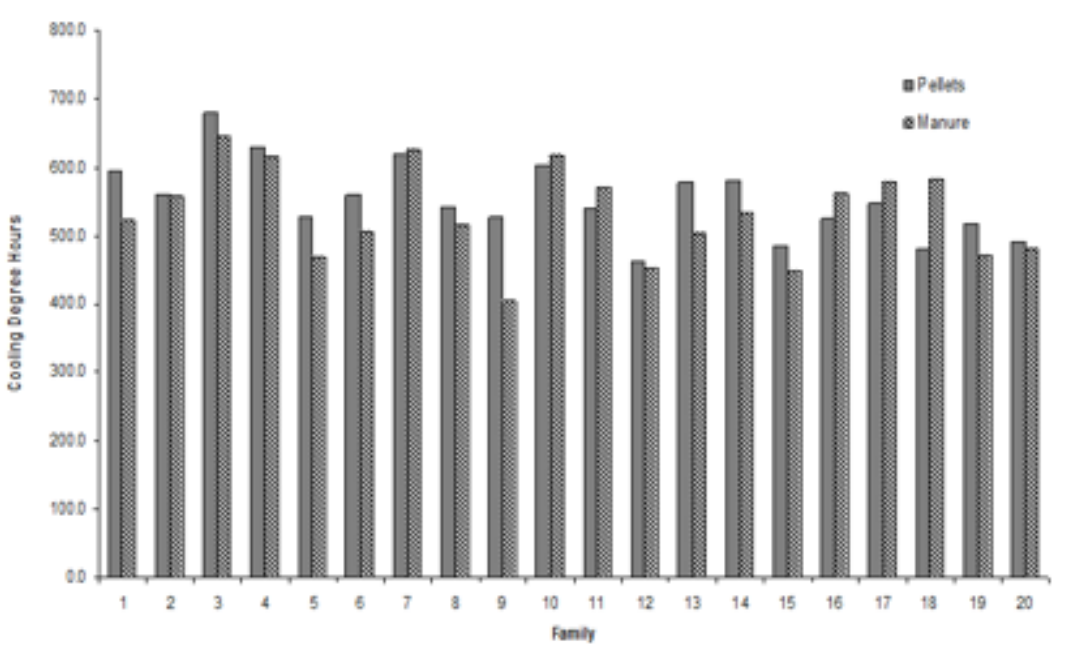




\section{Appendix 5: Presentations workshop consumer preferences}


Perspectives for selling to the European fish market

Overview results socio economics Diversify

12 June 2019, Gemma Tacken

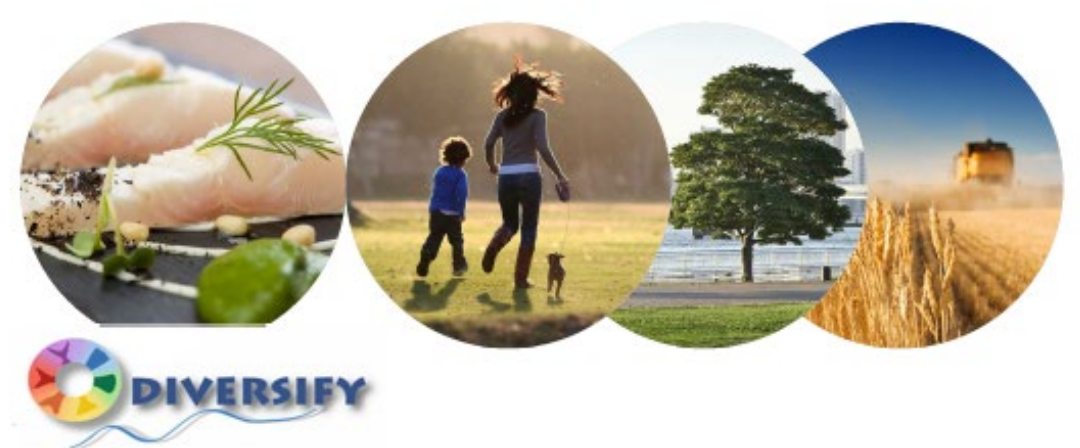

\section{Sea food production is changing}

\section{World capture fisheries and aquaculture production}

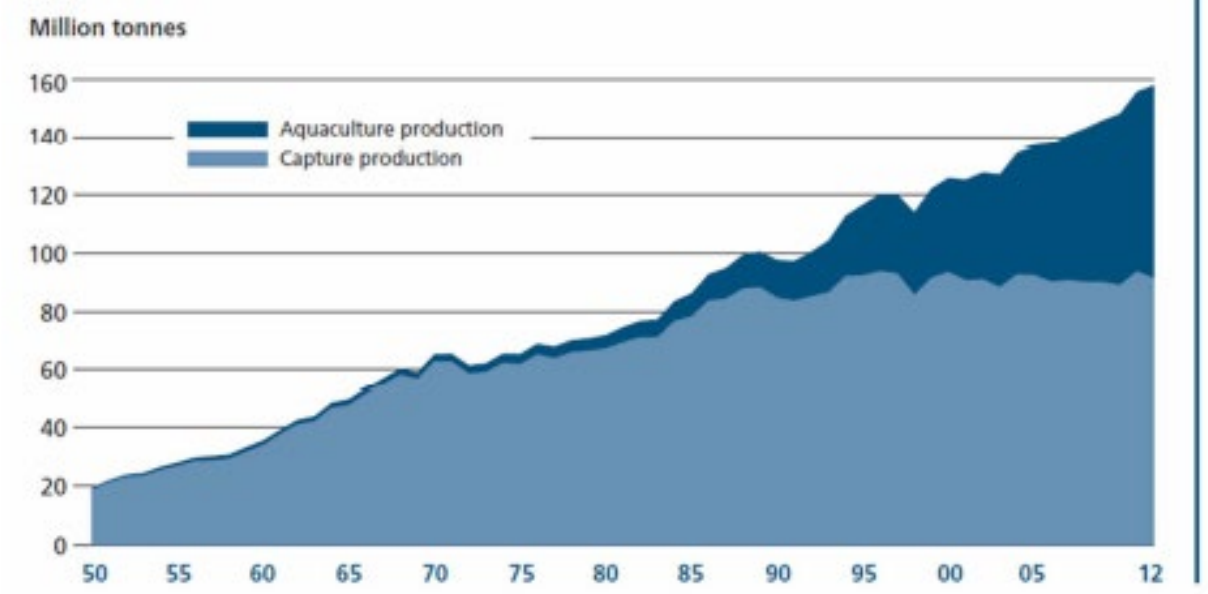




\section{Sea food buying is changing}

Seafood retail is changing:

Market share by value of fish retail in the UK, 1988-2003

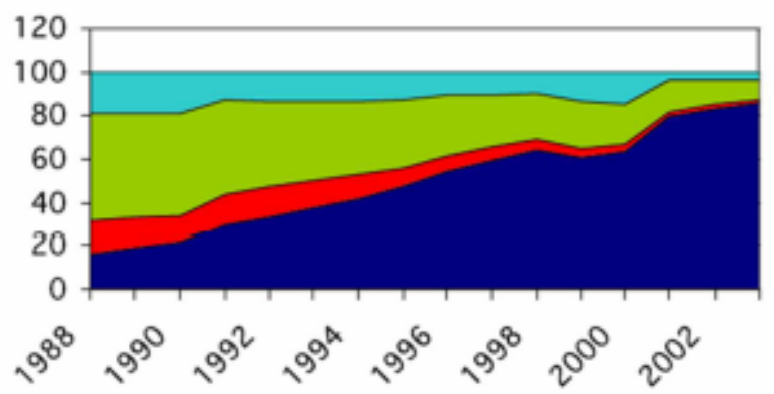

Supermarkets $\square$ Market stalls $\square$ Mongers $\quad \square$ Other outlets

\section{Sources Ses} Fisheries Industry
Autherity (SFIA)

WAGENINGEN

\section{Diversify Socio economics}

- WP 27 Institutional and organizational context

- WP28 New product development

- WP29 Consumer value perceptions and behavioural change

- WP30 Business model and market development strategy 


\section{Research partners}

\section{ノ IRTA \\ AARHUS UNIVERSITY}
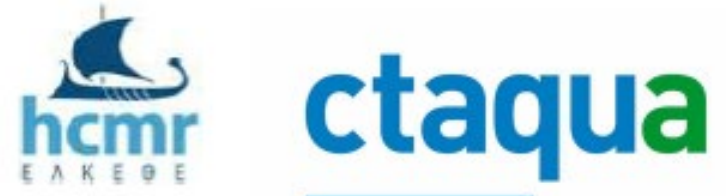

11 Departamento de Biologia Animal, Edafologia y Ceologia Universidad de La Laguna

HeUENCR ReSEARCH House

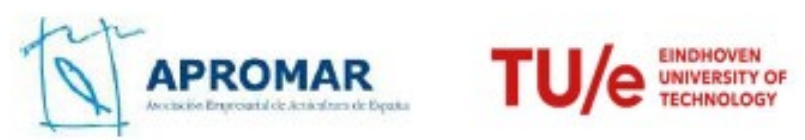

DAGENINGEN

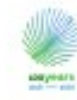

diversiev

\section{Funneling approach}

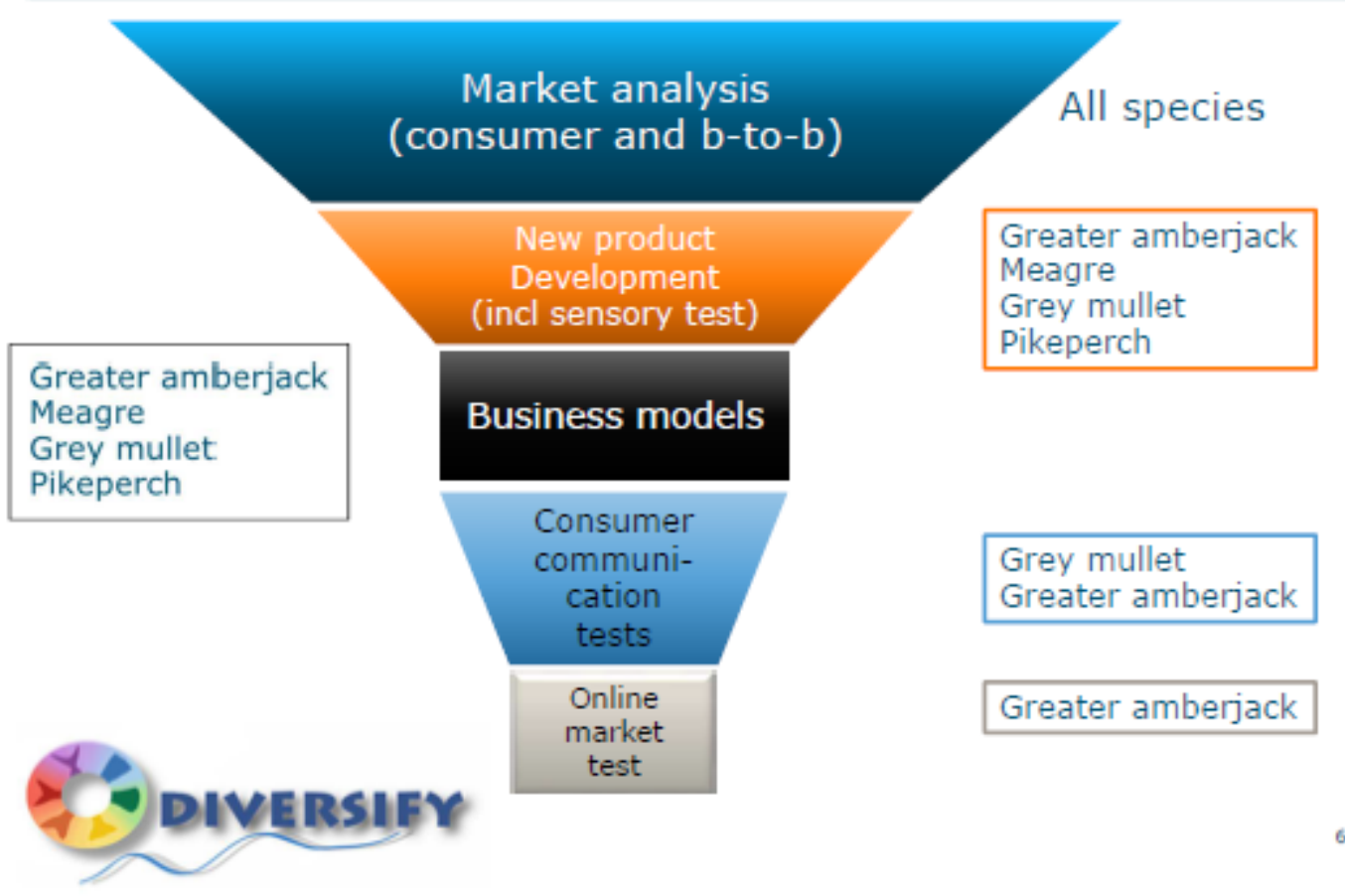




\section{Market analysis}

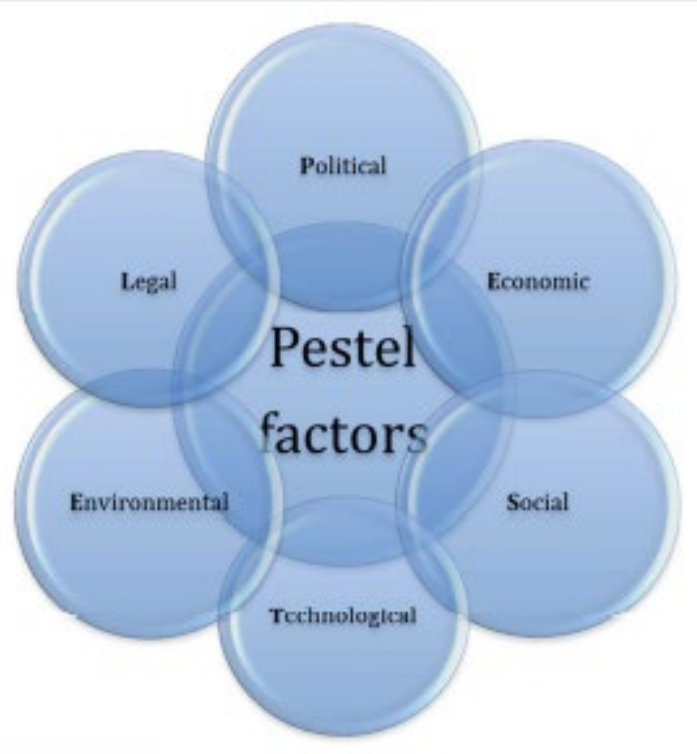

DIVERSIFY

\section{In favour of new products in the market ...}

- Government programmes support fish intake, since

- fish is perceived as more healthy than meat, or

- higher fish consumption is stimulated from a more varied protein consumption perspective

- Aquaculture is perceived as more sustainable than wild catch

- Aquaculture of these new species can bring employment in regions with high unemployment

- Increasing world wide demand for proteins, which might increase the price for fish products

- Consumers decrease meat and meat product consumption for health reasons (WHO advice) 


\section{Number of new fish products launched in the EU market}

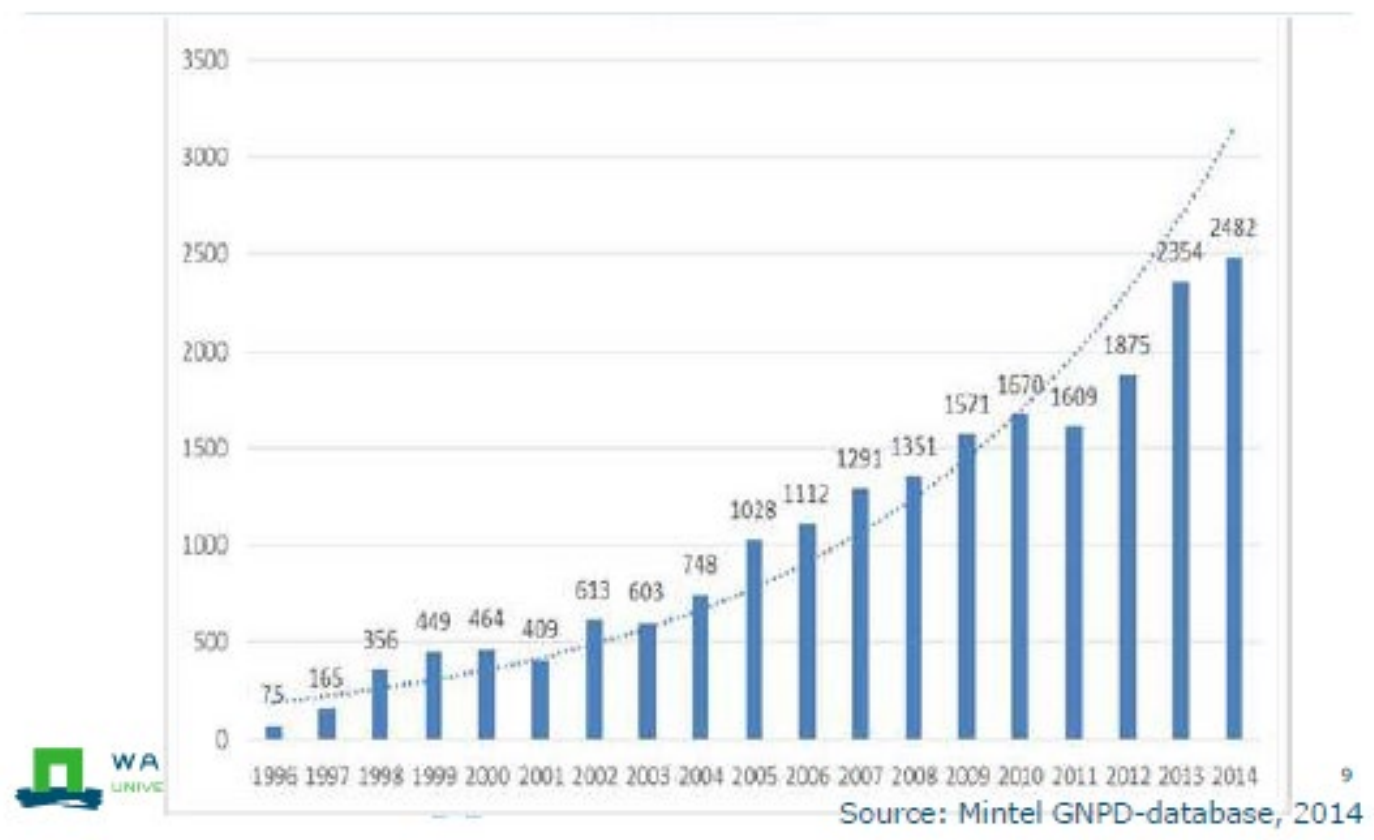

Fish product launches per year for the selected 5 EU countries

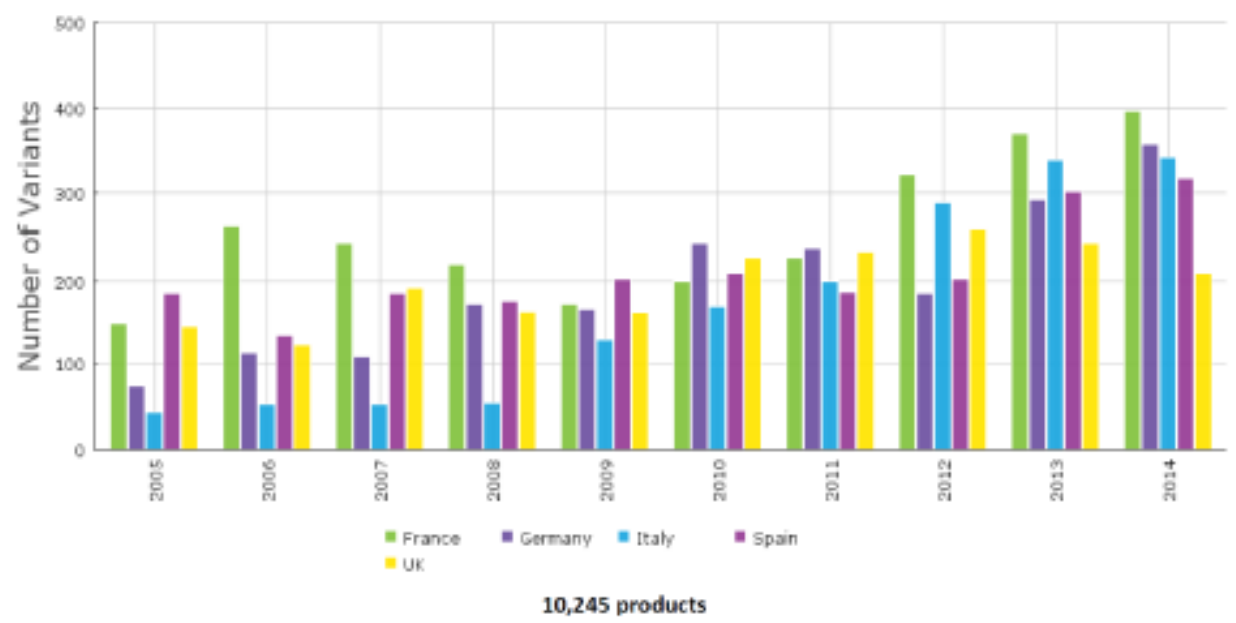

DAGENINGEN

Source: Mintel GNPD-database, 2014 


\section{Points of attention ...}

- The protein market in the EU is nearly stable, only in emerging countries growth of protein intake is to be expected

- Competition on protein sources will increase, since soy and milk based meat substitutes come in the market with large promotion budgets.

- Certification is a requirement for buyers. Per buyer the requirements are different, these are not country dependent but party dependent

- Most fish species are not well-known. So before market introduction the species have to be positioned in relation to other fish species

- Consumer think in terms of recipes, so development of recipes is very important

DAGENINGEN

\section{Two potential segments for new products}

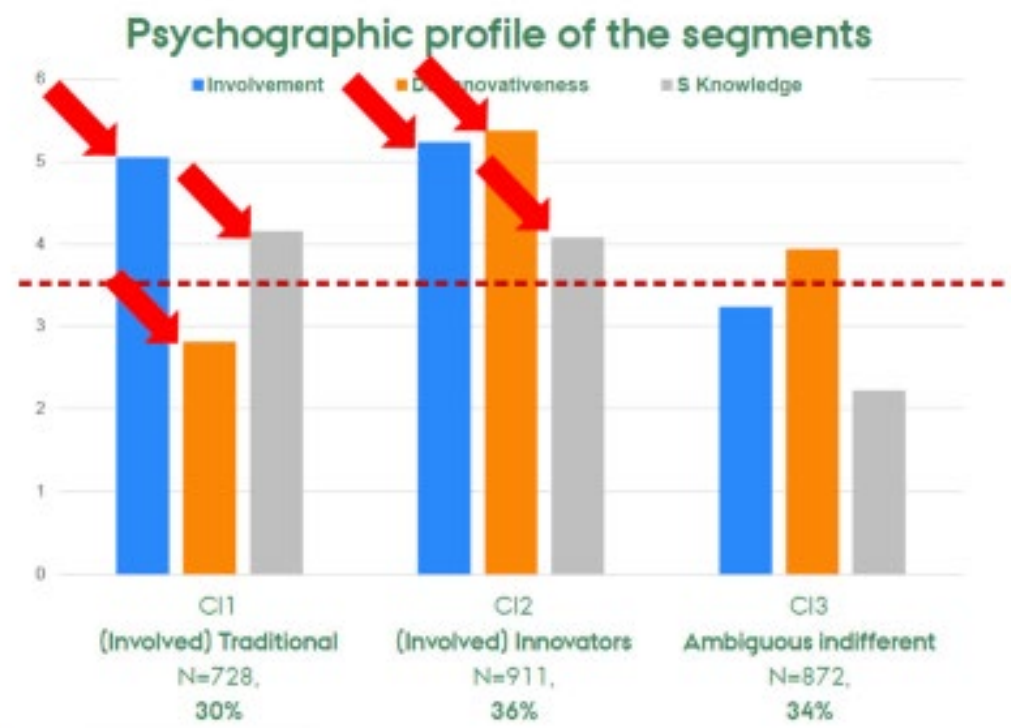




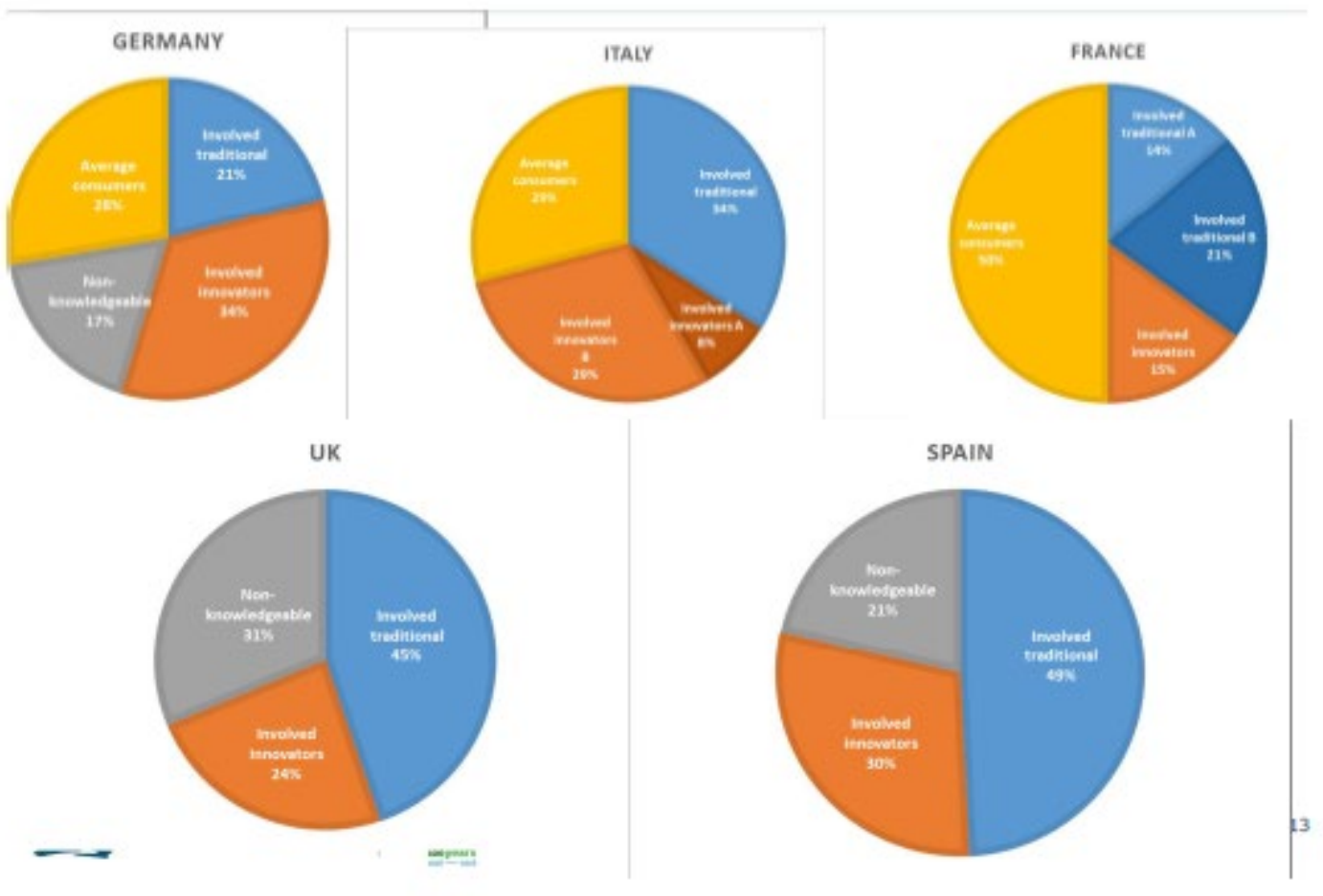

\section{Sea food consumption is changing (1)}

- \% of income spend on food has declined in most countries due to the crisis, but this will (partly) recover

- Tuna, cod, salmon and shrimps are most consumed across the EU. The fish market for flatfish and small pelagics is saturated but market needs for shrimps, groundfish, salmonids and tuna are not satisfied with local production/catches.

- Good filets and hardly any or easy bones

- Northern EU countries eat more processed fish than southern EU countries, but this changes rapidly now market shares of supermarkets are growing for fresh products in the southern EU.

- Minorities grow faster than locals in most countries, so ethnic developments change the eating habits and 


\section{Sea food consumption is changing (2)}

- Personal well-being and (health) impact are growing motives for food choices.

- Price quality relationships have become a leading buying motive due to the crisis

- Increase of fresh fish assortment in supermarkets

- Concentration in sea food consumption areas is fading out to other areas due to increasing high quality availability in supermarkets and hypermarkets all-over the countries

- Increasing demand for value added products like marinated fish

- Saturation of the protein market in the EU. Growth can only be reached by defeating the competition.

WagENINGEN

\section{New product ideas and prototypes (1)}

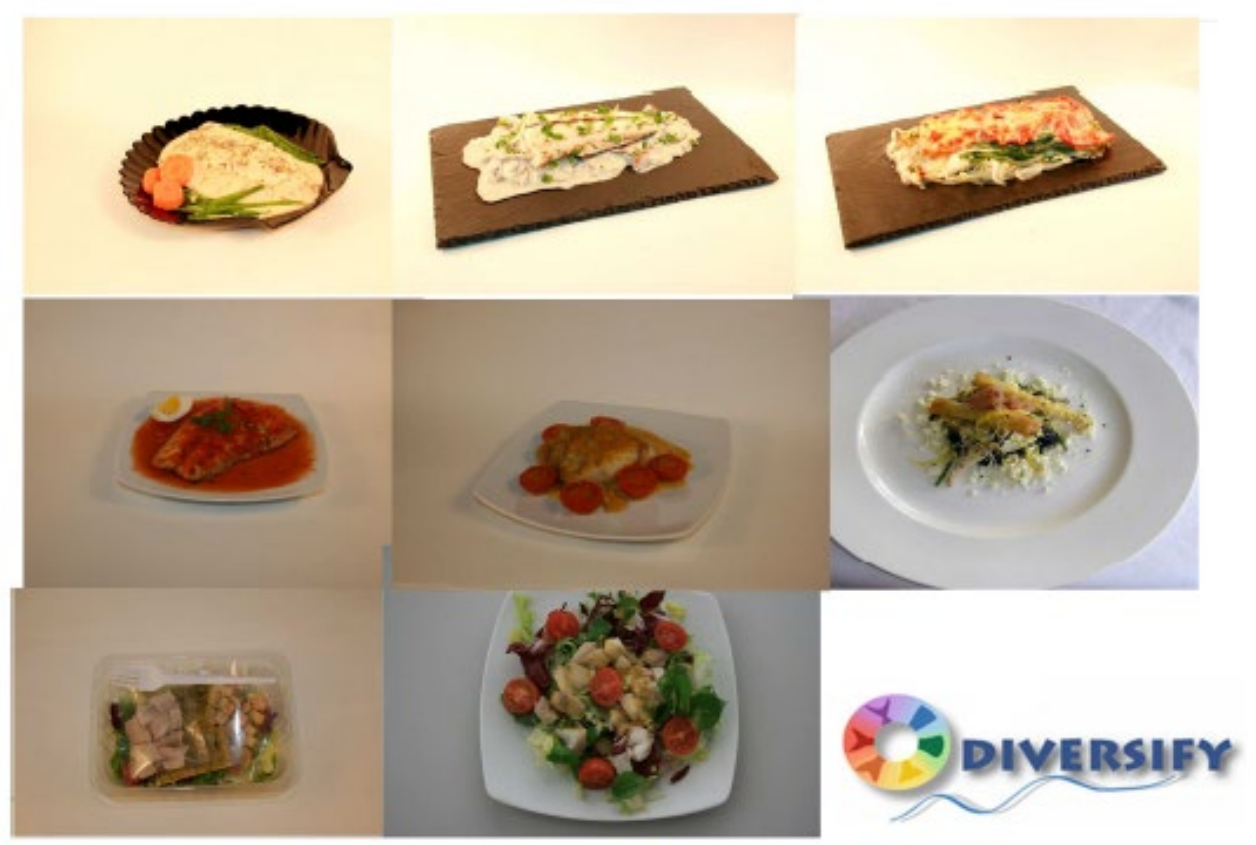




\section{New product ideas and prototypes (2)}

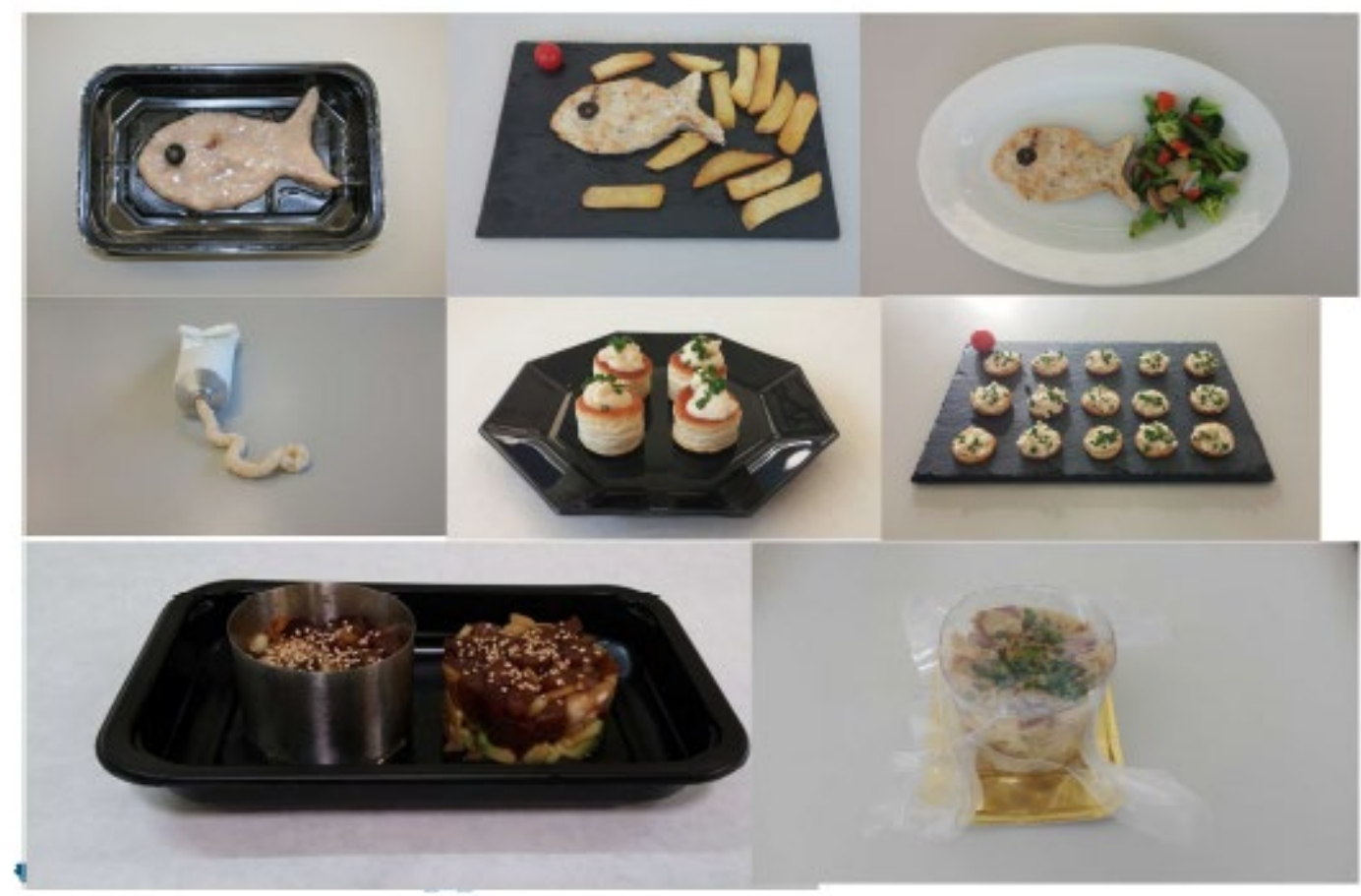

\section{Attributes important in communication}

- Country of origin for personal identification

- Use nutrition and health claims if possible (EGO vs ECO)

- Certification with respect to sustainability is important but not coherent 


\section{Market test}

- Help consumers in positioning of the new species

- Innovative consumers try new products first

- Communicate that the product is environmental friendly helps in some countries

- Only in Spain price promotion helps, in other countries it works out negative

- Southern European consumers are more open for a new species as greater amberjack

- Market penetration should be done country by country instead of pan-European

\section{When will new products be a success?}

- What ultimately determines the success for new products is:

- providing products that offer advantages that meet consumers' different needs,

- The species can rely on a positive image and

- Gaining fast a strong market position based on cooperation between suppliers, the industry and retail 
Thank you for your attention. Please feel free to ask questions

More information:

gemma.tacken@wur.nl

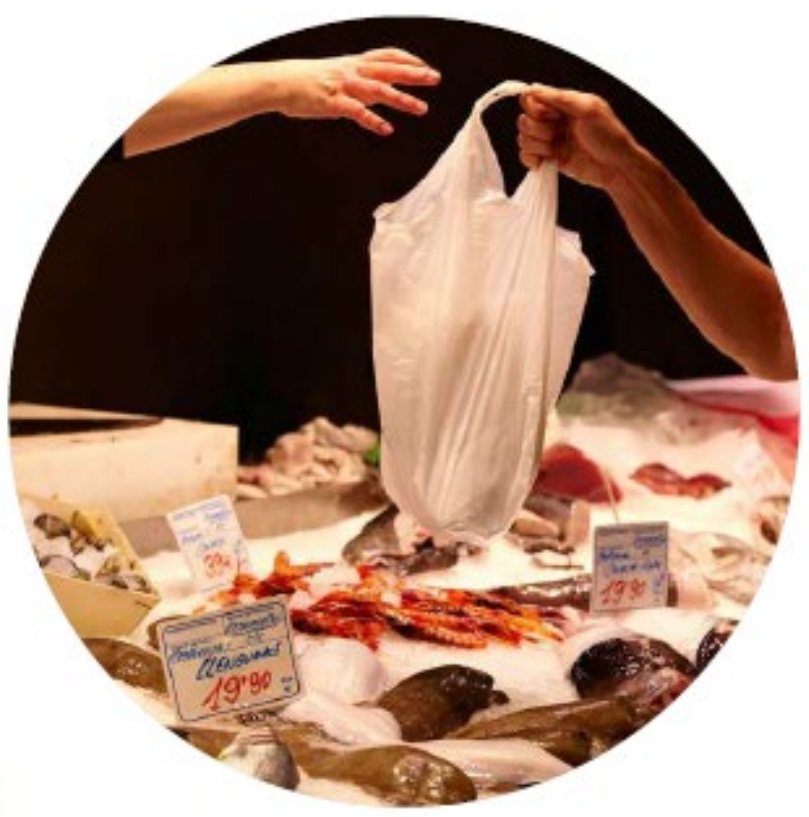

Or www.diversifyfish.eu

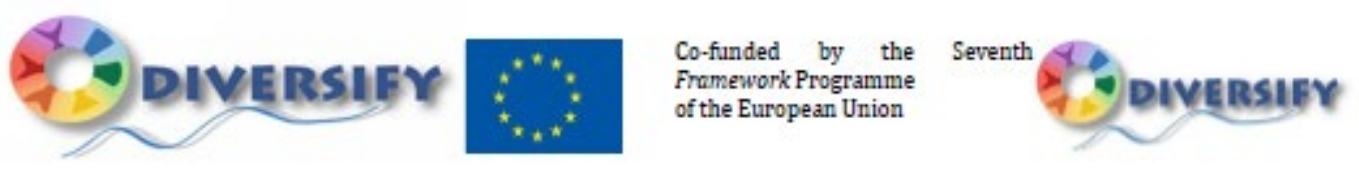


Appendix 6: Lantern fish project and the win-win supporting tilapia culture; ideas for a long term Lantern fish - Tilapia project. 


\section{Lantern fish project and the win-win supporting tilapia culture}

In Autumn $2018 \mathrm{dr}$. Kals was invited by IFSRO to write a quotation for the joint research project: "Improvement of the fish value chain in Iran: value creation in fish and fish products", which is based on the results of the fact finding mission in 2017 and the research priorities given by The Islamic Republic of Iran (appendix 3).

During a Skype meeting in February 2019 with the director of IFSRO, IFSRO research colleagues, dr. Hans Smolders the Dutch agricultural attaché, dr. Kals and WUR research colleagues it was decided to focus solely on the processing of Lantern fish. A new proposal: "Improvement of the fish value chain in Iran: Increase of the use of lantern fish for both fishmeal and human consumption phase 1", was written and discussed with IFSRO during our meeting at AREEO, Teheran in June. IFSRO was determined to start with the project as soon as possible. Yet, the major bottleneck to start the project appeared to be the restrained position of the private sector due to the economic sanctions. However, all agree the Dutch-Iranian joint cooperation can play an important role in the development of the Iranian fish value chain.

\section{Business case Lantern fish}

The proposed activities of the Lantern fish project can be read in appendix 2 . Interesting is the business case behind it and the connection with the development of large scale tilapia farming in Iran.

The average mass balance of the processing of marine ingredients (e.g. Lantern fish) into fishmeal and fish oil is that from every metric ton of fish, $250 \mathrm{~kg}$ of fish meal and $50 \mathrm{~kg}$ of fish oil can be produced. In addition, it is interesting to note that every ton of marine ingredients contains approximately $700 \mathrm{~kg}$ of water, a resource getting more valuable every day. Focussing on the case of Lantern fish. The goal of Iran is to increase the landings of Lantern fish to 100 kton year $^{-1}$ in the next five years of which $50 \%$ will be allocated for human consumption and the other $50 \%$ for the production of fishmeal and fish oil.

\section{Protein of Lantern fish for human consumption}

The price of fish protein as a half fabricate (mince) for human consumption depends largely on the quality of the product. The whiteness and colour homogeneity of fish mince are the major factors that determine consumer acceptance and price. In Britain fish mince is classified in three qualities, A, B and C standing for mince having little discolouration, mince discoloured with blood and haem proteins and discoloured mince, respectively, with prices ranging from $£ 1000$ to $£ 400$ ton $^{-1}$ for the best and less quality products (Shahidi, 2007). The quality and therefore the price of fish protein/mince from Lantern fish is difficult to predict at this moment as the production of fish protein/mince for human consumption is one of the research priorities of the proposal. However, Shaviklo and Rafipour (2013) showed it is possible to produce prototype Lantern fish products for human consumption.

\section{Production of fishmeal and fish oil from Lantern fish}

The production of fishmeal and fish oil is a well-known process and according to (ElMowafi and Berntssen, 2010) the composition of fish meal and oil from Lantern fish is comparable to that of South American fish meal and oil. Assuming that 50\% from the expected landings of $100 \mathrm{kton}^{-1}$ can provide Iran with 2500 ton of fish oil and 12500 ton of FM $\mathrm{y}^{-1}$ this represents a value of approximately 24 million US $\$ \mathrm{y}^{-1}$.

(https://www.indexmundi.com/commodities/?commodity $=$ fish-meal\&months $=60$ and https://www.statista.com/statistics/762335/fish-oil-price-worldwide/). More 
importantly, these amounts of fish meal and fish oil are more than sufficient to produce 200000 ton $12500 /(60 / 1000)$ tilapia feed (fishmeal is limiting as for 200000 ton of tilapia feed only 1042 ton of fish oil is needed).

To conclude the production of fish meal and fish oil from Lantern fish could support the growth of the Iranian tilapia culture up to a production of 150.000 ton $\mathrm{y}^{-1}$ assuming the non-marine feed ingredients are available and a feed conversion ratio from tilapia feed to tilapia of 1.3, which fits with the FIFO ratio of 0.3 (Figure 1 ).
Summary of FIFO Ratios as calculated by IFFO

\begin{tabular}{|c|c|c|c|c|c|c|}
\hline Species & $\underset{\%}{\text { FM in Diet }}$ & FO in Diet \% & $\begin{array}{l}\text { Yield of FM } \\
\text { from wild } \\
\text { fish \% }\end{array}$ & $\begin{array}{c}\begin{array}{c}\text { Yield of FO } \\
\text { from wild } \\
\text { fish \% }\end{array} \\
\text {. }\end{array}$ & $\begin{array}{l}\text { FIFO } \\
\text { Ratio }\end{array}$ & $\begin{array}{c}\text { Wild Fish } \\
\text { used }, 000 \\
t\end{array}$ \\
\hline Salmon & 30 & 20 & $\overline{24}$ & 5 & 2.2 & 3157 \\
\hline Trout & 30 & 15 & 24 & 5 & 1.9 & 1226 \\
\hline Eel & 55 & 5 & 24 & 5 & 2.9 & 784 \\
\hline Marine Fish & 32 & 8 & 24 & 5 & 1.9 & 2858 \\
\hline Shrimp & 20 & 2 & 24 & 5 & 1.2 & 3754 \\
\hline FW Crustaceans & 15 & 1.5 & 24 & 5 & 0.5 & 586 \\
\hline Tilapia & 6 & 0.5 & 24 & 5 & 0.3 & 718 \\
\hline Catfish & 10 & 1.7 & 24 & 5 & 0.4 & 777 \\
\hline Milkfish & 3 & 1 & 24 & 5 & 0.1 & 65 \\
\hline Carp & 5 & 0 & 24 & 5 & 0.1 & 1460 \\
\hline Misc FW Cam. Fish & 40 & 5 & 24 & 5 & 0.5 & 386 \\
\hline $\begin{array}{l}\text { Total of Fed farmed } \\
\text { fish \& shellfish }\end{array}$ & & & & & 0.66 & 15770 \\
\hline Pigs & 0.25 & 0 & $\overline{24}$ & 5 & 0.03 & 4748 \\
\hline Poultry & 0.3 & 0 & 24 & 5 & 0.02 & 1577 \\
\hline Total & & & & & 0.09 & 22096 \\
\hline
\end{tabular}

Figure 1: the fishmeal and fish oil percentages in diet of different fish species and their fish in fish out ratio (FIFO). From http://www.iffo.net/

\section{Ideas for a multi-year Lantern fish - Tilapia project}

\section{August 2019, Jeroen Kals \& Hans Komen}
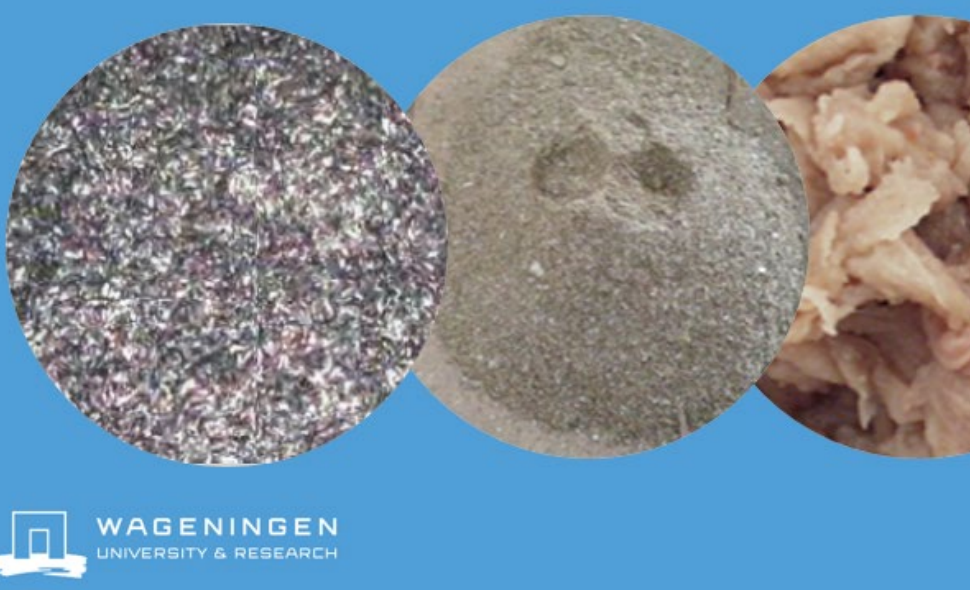
Increase use of lantern fish for both fishmeal, fish oil and human consumption

1. Analyses current raw material

2. Contacting suppliers of technology

3. Production fish oil on laboratory scale

4. Quality assessment of the product

5. Production functional protein and fish oil on

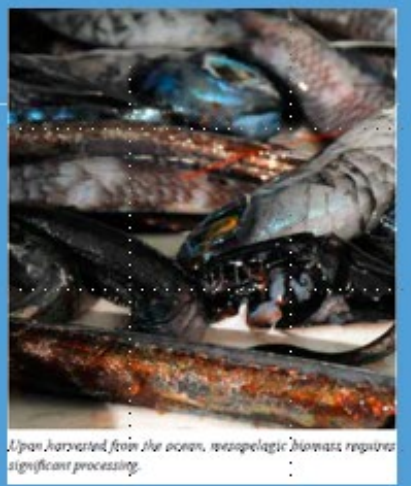
laboratory scale

6. Quality assessment of product

7. Production of representative samples

8. Potential added value using lantern fish

\section{Production of fish oil without production}

\section{$\underline{\text { functional protein }}$}

- State-of-the-art fish oil production: input of fresh fish and output of fish oil and denatured protein meal (fish meal) or fish hydrolysate

- Technology offered by commercial parties. The options for lantern fish will be assessed by the 3 steps:

- Approaching technology providers

- Production of raw fish oil samples on laboratory scale

- Quality assessment of the product
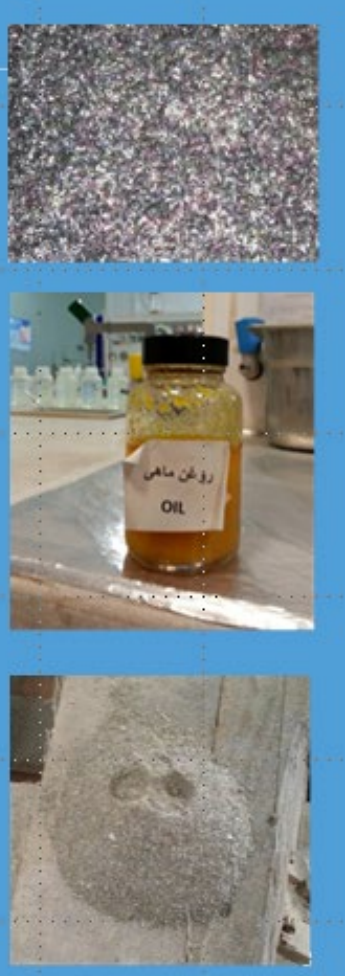


\section{Production of fish oil and functional protein}

- Production of functional protein requires a technology without a heating step before the protein has been removed from the oil fraction

- WR demonstrated production of sarcoplasmic (water soluble) and mvofibrilliar (salt soluble) proteins from fish and fish by products

- Process can be the base for technology development protein production with functional properties from lantern fish
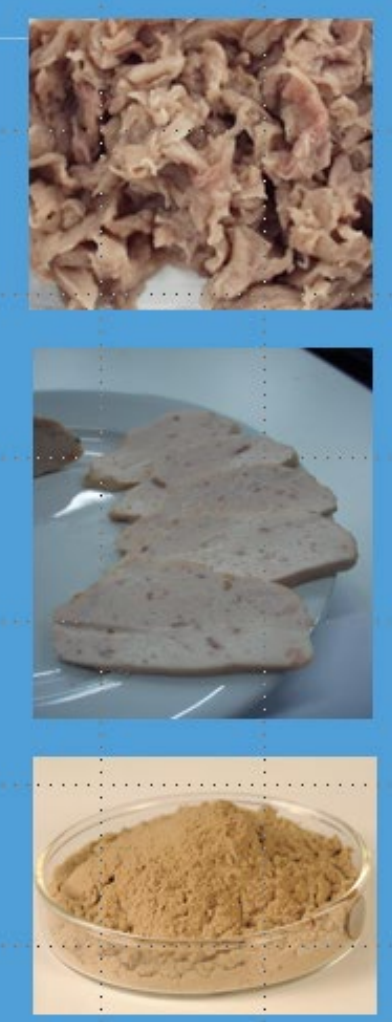

Development tilapia culture in Iran

1. Analyses current state of the art

2. Contacting suppliers of technology

3. Making blueprint tilapia farm using bore water

4. Making blueprint tilapia hatchery

5. Capacity building breeding

6. Development infrastructure tilapia feed

7. Processing of tilapia into products

8. Product development
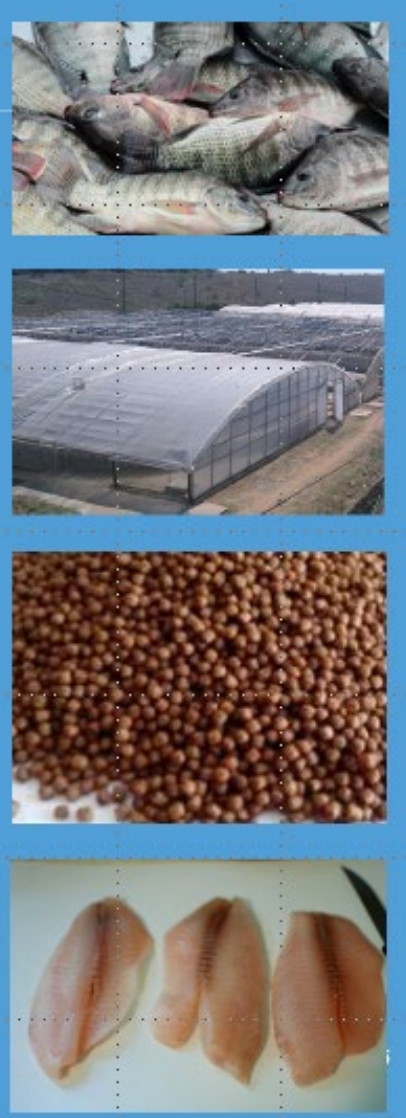


\section{Development tilapia culture in Iran}

7. Contacting suppliers of technology

8. Processing of tilapia into products

9. Processing by products into products

10. Product development
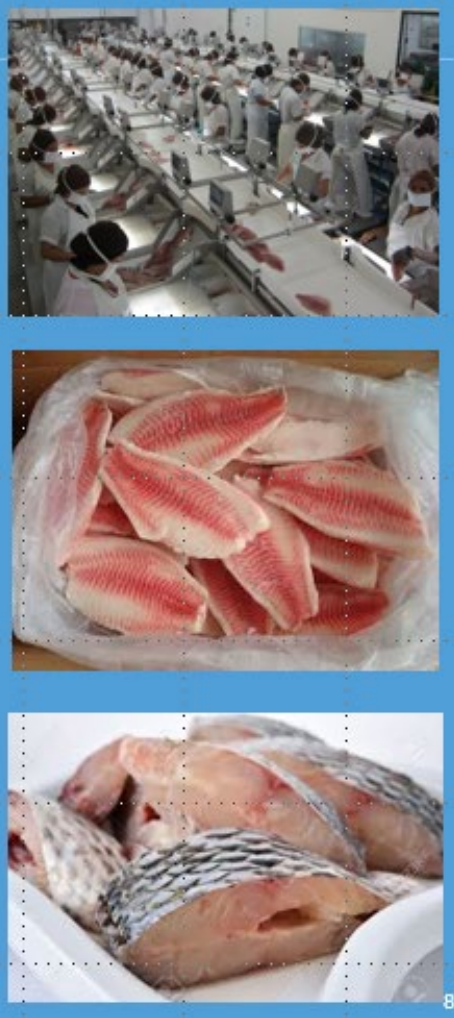

Development tilapia culture in Iran

4. Capacity building breeding

5. Contacting suppliers of technology

6. Development infrastructure tilapia feed

- feed using Lantern fish or by products

- feed using local ingredients
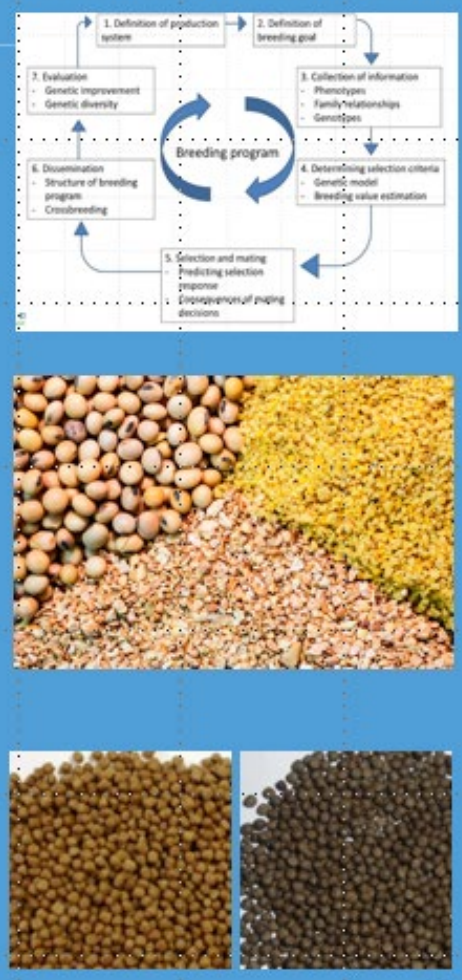



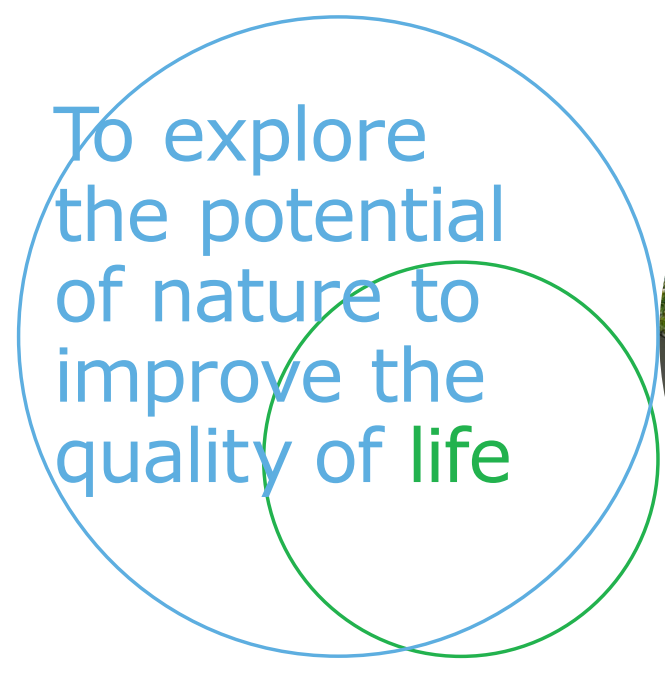

Wageningen Livestock Research P.O. Box 338

6700 AH Wageningen

The Netherlands

$\mathrm{T}+31(0) 317483953$

E info.livestockresearch@wur.nl

www.wur.nl/livestock-research

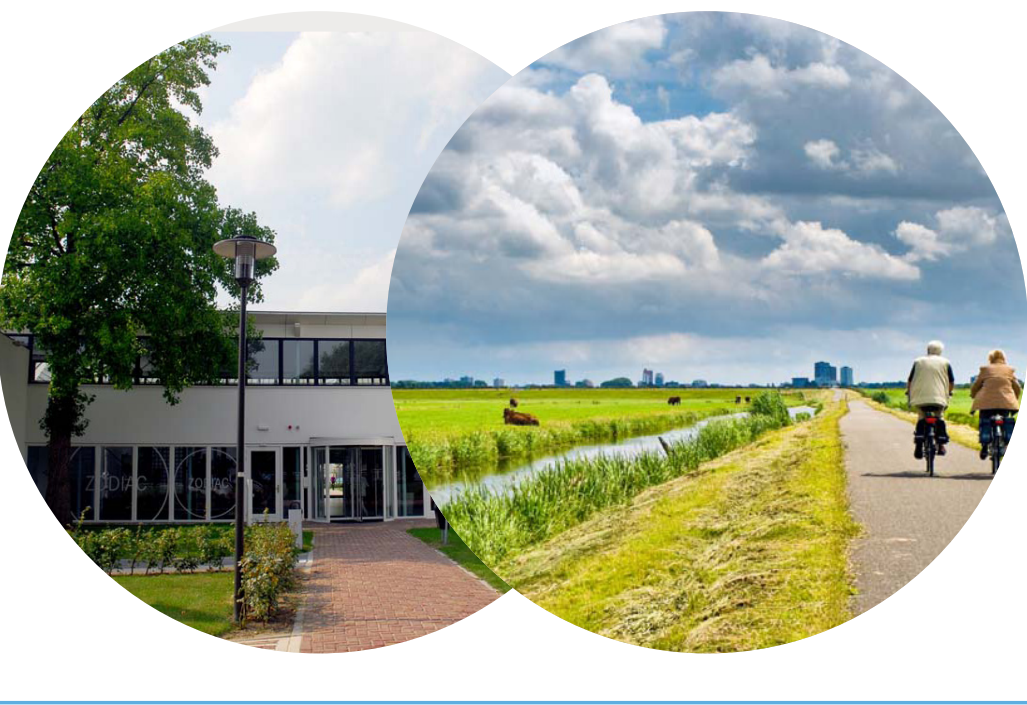

Together with our clients, we integrate scientific know-how and practical experience to develop livestock concepts for the 21st century. With our expertise on innovative livestock systems, nutrition, welfare, genetics and environmental impact of livestock farming and our state-of-the art research facilities, such as Dairy Campus and Swine Innovation Centre Sterksel, we support our customers to find solutions for current and future challenges.

The mission of Wageningen University \& Research is 'To explore the potential of nature to improve the quality of life'. Within Wageningen University, nine specialised research institutes of the DLO Foundation have joined forces with Wageningen University to help answer the most important questions in the domain of healthy food and living environment. With approximately 30 locations, 6,000 members of staff and 10,000 students, Wageningen UR is one of the leading organisations in its domain worldwide. The integral approach to problems and the cooperation between the various disciplines are at the heart of the unique Wageningen Approach. 